\title{
ESTUDO DE AQÜÍFEROS VULCANO-SEDIMENTARES NA SUB- BACIA HIDROGRÁFICA DO RIO UCHUSUMA (ZONA DE FRONTEIRA PERU, BOLÍVIA E CHILE)
}

\author{
VICTORIANO ROLANDO APAZA CAMPOS
}

Orientador: Prof. Dr. Uriel Duarte

TESE DE DOUTORAMENTO

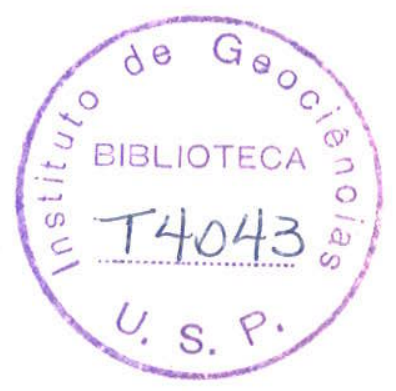

COMISSÃO JULGADORA

Nome

Presidente Prof. Dr. Uriel Duarte

Examinadores: Prof. Dr. Ernani Francisco da Rosa Filho

Prof. Dr. José Domingos Faraco Gallas

Prof. Dr. Paulo Roberto dos Santos

Prof. Dr. Rubem La Laina Porto

SÃO PAULO 2004

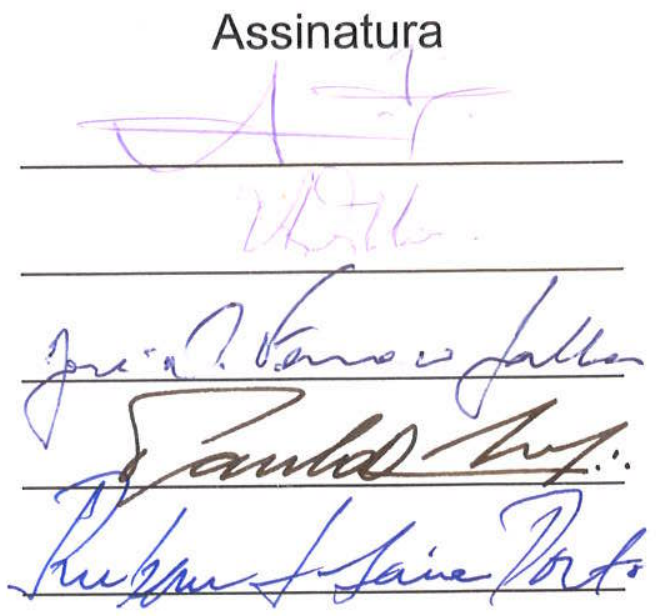


UNIVERSIDADE DE SÃO PAULO

INSTITUTO DE GEOCIÊNCIAS

ESTUDO DE AQÜÍFEROS VULCANO-SEDIMENTARES NA SUBBACIA HIDROGRÁFICA DO RIO UCHUSUMA (ZONA DE FRONTEIRA PERU, BOLIVIA E CHILE)

Victoriano Rolando Apaza Campos

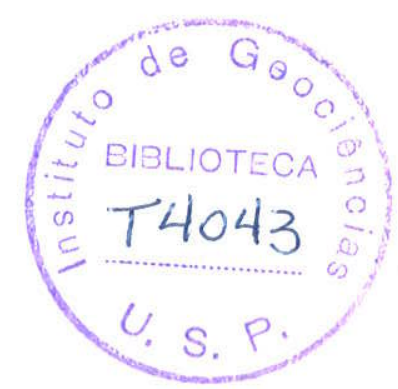

Orientador: Prof. Dr. Uriel Duarte

TESE DE DOUTORAMENTO

Programa de Pós-Graduação em Recursos Minerais e Hidrogeologia

SÃO PAULO

2004

DEDALUS - Acervo - IGC

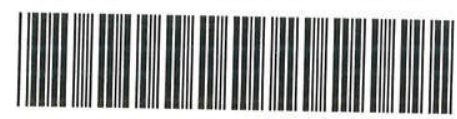

30900015054 
A ti, senhor elevo minha gratidão

Sejas louvado pelo cuidado paterno.

Sobre a verdade ergue teu reino superno.

Teu o louvor seja somente, senhor.

Sim, pelo século eterno.

Graças por haver suscitado ânimo,

nos momentos mais dificeis da minha vida.

Graças por ter-me fortalecido

nos momentos de maior vacilaçăo e obscuridade.

Tua luz sempre me guie, e guie o destino de meu lar, até nos encontrarmos.

A memória da minha mãe Valentina Campos.

A Karina Aguilar Salcedo minha esposa e companheira, a meus fihlos Zaida, Rubén e Rocío que entenderam minha ausencia e sempre estiveram com uma palavra de apoio e carinho.

A minha irmá Juana e seu esposo Rolando $R$. Graças pelo incentivo constante. 


\section{AGRADECIMENTOS.}

Expresso-lhes meus eternos agradecimentos, a entidades e pessoas que tiveram a gentileza de me cooperar ao longo do desenvolvimento do presente trabalho $e$, ter encontrado neles as facilidades, sejam de caracter financeira, informações como sugestões recebidas, tornando-se em aportes valiosos. Seja meus reconhecimentos a:

Instituto Geociências, em especial ao (Departamento de Geologia Sedimentar e Ambiental - Programa de recursos Minerais e Hidrogeologia) pela receptividade e oportunidade de me brindar para realizar o curso de Doutorado, fornecendo oportunidade para aperfeiçoamento de profissionais estrangeiros.

Ao Prof.Dr. Uriel Duarte, meu orientador, pela gentileza de me apoiar nas dificuldades por mi encontradas no desenvolvimento da pesquisa, sugestões e críticas recebidas na concretização deste trabahho.

Conselho Nacional de Desenvolvimento Científico e tecnólogico (CNPq) pelo apoio fornecido sob a forma de Bolsa de estudos.

Aos professores do Departamento de Recursos Minerais e Hidrogeologia pela oportunidade de realização da pesquisa.

Ao Dr. Victor Velásquez Fernandez amigo que sempre esteve disponível ao esclarecimento de dúvidas, discussões do trabalho e às críticas construtivas.

A Sra Ana Paula Cabanal e Magali, pela orientação e facilidade encontradas na orientação no cumprimento de normas protocolares e curriculares em todo o período do curso.

A Universidad Nacional del Altiplano Puno-Perú pela assistência financeira durante o período de afastamento por estudos do curso de Pós-graduação

A Maestría em Desarrollo Rural de la Universidad Nacional del Altiplano Puno pelo apoio financeiro na fase da conclusão do trabalho.

Ao Laboratório Centro de Pesquisa de Águas Subterrâneas CEPAS da IG-USP e Laboratório de Química da Universidad Nacional del Altiplano Puno - Peru pelo suporte na realização de análises química das águas.

A Maristela Prestes pela orientação na normalização de referências bibliográficas.

A Iraldo, Cecília, Virgínia. Graças pela colaboração durante a produção do volume final.

A todo o pessoal da Gráfica do Instituto de Geociências pelo montagem da tese.

A Fernando Roberto de Oliveira e esposa excelente família graças pelo apoio encontrado durante minha estada no Brasil.

Muito obrigado a todos. 


\section{NDICE}

1.0.0. - INTRODUÇÃo

1.1.0 - Apresentação da Área de Estudo

1.2.0.- Objetivo geral

1.2.1.- Objetivo específico

1.3.0.- Localização da área do estudo

1.4.0.- Conflito sobre as águas superficiais na região

1.5.0.- Histórico de projetos de derivação de águas do Altiplano para o litoral Pacífico

1.6.0.- Justificativa para a escolha da área de estudo

2.0.0.- METODOLOGIA

2.1.0.- Divisão da área de pesquisa

2.2.0- Campo de pesquisa

2.3.0.- Pesquisa da documentação existente e validação dos estudos anteriores

2.3.1.- Revisão da literatura

2.4.0.- Cadastramento de pontos de água

2.5.0.- Instalação de poços de observação.

2.6.0.- Potenciometria

2.7.0.- Explorações geofísicas.

2.8.0.- Análise sedimentar das formações aqüiferas

2.9.0.- Interpretação de imagem satélite Landsat Thematic Mapper

2.10.0.- Avaliação hidrodinâmica

2.11.0.- Estimativa do balanço hidrológico

2.12.0.- Avaliação da qualidade química das águas 20

3.0.0.- CLIMATOLOGIA E BALANÇO HÍDRICO.

3.1.0.- Amplitude do periodo analisado

3.2.0.- Rede de estações meteorológicas

3.3.0.- Parâmetros climáticos considerados

3.3.1.- Precipitação

3.3.2.- Temperatura 24

3.3.3.- Umidade relativa 28

3.3.4.- Vento 29

3.3.5.- Cálculo de evapotranspiração 30

3.3.6.- Análise de dados de Evapotranspiração Potencial (ETP).

3.4.0.- Balanço hídrico 33

3.4.1.- Estimativa do balanço hídrico 34 
4.0.0.- GEOMORFOLOGIA E GEOLOGIA

4.1.0..- Características geomorfológicas regionais do altiplano

4.2.0.- Características geomorfológicas da bacia do rio Uchusuma

4.3.0.- Evolução geomorfológica

4.4.0.- Feições principais do relevo local

4.5.0.- Geologia regional

4.6.0.- Estratigrafia da sub-bacia Uchusuma

4.7.0.- Aspecto estrutural

4.7.1.- Deformações rúptis 66

5.0.0.- GEOFÍSICA 69

5.1.0. - Base teórica do método de eletrorresistividade 70

5.2.0.- Procedimento aplicado 70

5.3.0. Levantamento de dados de campo 71

5.4.0.- Análise de levantamento de dados 72

5.4.1.- Perfis geológicos - geofísicos

5.4.2.- Mapa de contorno de resistividade verdadeira 81

5.4.3.- Mapa Isoespessura da Formação Sencca ou Peréz 82

6.0.0.- HIDROGEOLOGIA 86

6.1.0.- Sistema hídrico Uchusuma 86

6.2.0. Cadastramento de fontes de água $\quad 87$

6.2.1.- Cadastramento de poços 88

6.2.2.- Cadastramento de nascentes 88

6.3.0.- Características sedimentares dos sistemas aqüíferos 92

6.3.1.- Aqüífero livre $\quad 92$

6.3.2.- Aqüifero semiconfinado 94

6.4.0.- Geometria do reservatório e do aqüífero 96

6.5.0.- Potenciometria $\quad 97$

6.5.1.- Dinâmica de flutuações do nível da água do aqüífero freático 98

6.5.2.- Interpretação da morfologia do nível da água do aqüifero freático 101

6.6.0.- Aspectos de recarga de aqüifero 102

$\begin{array}{ll}\text { 7.0.0.- HIDRODINÂMICA } & 104\end{array}$

$\begin{array}{ll}\text { 7.1.0.- Metodologia empregada } & 105\end{array}$

7.1.1.- Avaliação das características construtivas dos poços de produção 105

$\begin{array}{ll}\text { 7.1.2.- Fundamentos de testes de bombeamento } & 107\end{array}$

$\begin{array}{ll}\text { 7.1.3.- Monitoramento de poços } & 108\end{array}$

7.2.0.- Análises e interpretação de testes de bombeamento 109

$\begin{array}{ll}\text { 7.2.1.- Fórmula de regime de não equilíbrio de Theis } & 110\end{array}$ 
7.2.2.- Fórmula modificada de regime de não equilíbrio - método de Jacob

7.2.3.- Aplicação do método de Jacob a análise de teste de bombeamento. 112

7.3.0.- Parâmetros hidrodinâmicos

7.4.0.- Análise da capacidade produtiva do aqüífero

8.1.0.-Características físico-químicas

8.1.1.- Condutividade elétrica

8.1.2.- $\mathrm{pH}$

8.1.3.- Dureza

8.2.0.- Qualidade química das águas

8.3.0.- Classificação das águas

8.3.1.- Classificação segundo os íons dominantes

8.3.2.- Qualidade da água para irrigação

8.3.3.- Qualidade da água para o consumo humano

9.1.0.- Avaliação de reservas

9.2.0.- Reservas reguladoras ou transitórias

9.3.0.- Reservas permanentes

9.4.0.- Vazão de oferta

9.5.0.- Potencialidade hídrica

10.1.0.- Considerações gerais

10.2.0.- Impacto ambiental gerado pela explotação de águas subterrâneas

10.2.1. - Avaliação de áreas úmidas e mananciais

10.3.0.- Problemas sócio - econômicos vinculados a derivação de água do Altiplano ao Pacífico

10.4.0.- Problemas de gerenciamento das bacias

10.5.0.- Conflitos regionais por recursos hídricos.

11.0.0.- CONCLUSÕES E RECOMENDAÇÕES 


\section{LISTA DE FIGURAS.}

1.- Localização da área do estudo

2.- Mapa da bacia transfronteiriça do rio Maure e localização de estações 23 metorológicas

3.- Curva de precipitação média mensal de cinco estações meteorológicas 26

4.- Histogramas de dados pluviométricos anuais 27

5 - Climatograma 28

6. Variação da temperatura nas diferentes épocas do ano 29

7.- ETP estimada por diferentes métodos para sub-bacia Uchusuma 33

8.- Esquema do balanço hídrico 35

9.- Diagrama do balanço hídrico - método de Thornthwaite 37

10.- Mapa morfoestructural da região do altiplano 38

11.- Modelo do relevo digital da sub-bacia do Rio Uchusuma 40

12.- Mapa da rede hídrica do rio Uchusuma 42

13.- Mapa geomorfológico 45

14.- Características espectrais das unidades litoestratigráficas: sub-bacia Uchusuma

15.- Mapa geológico da sub-bacia do rio Uchusuma 54

16.- Abrangência da bacia sedimentar da Formação Maure no Altiplano 55

17.- Linhamentos morfotectônicos - área de fronteira Peru, Bolivia e Chile 68

18.- Mapa de Localização de pontos de Sondagem Elétrica Vertical SEVs 73

19.- Perfil geológico geofísico $\mathrm{AA}^{\prime}, \mathrm{BB}^{\prime} \quad 77$

20.- Perfil geológico geofísico CC 78

21.- Perfil geoiógico geofísico DD', EE' 79

22.- Perfil elétrico do poço de Charaña (ALT-CH) Bolívia 80

23.- Mapa de contornos de resistividade verdadeira $a b / 2=100 \mathrm{~m}$

24.- Mapa de contornos de resistividade verdadeira $a b / 2=300 \mathrm{~m}$

25.- Mapa de isópacas da Formação Pérez ou Sencca. 85

26.- Mapa de contornos equipontenciais e localização de fontes de água 89

27.- Curva representativa de teste de aqüifero Poço PA-6 e PCH-ALT 114

28.- Capacidades específicas de produção dos poços 122

29.- Variação de condutividade elétrica zona de Ayro período abril 2000 a março 2003

30.- Variação de condutividade elétrica zona de Charaña periodo abril 2000 a $\begin{array}{ll}\text { março } 2003 & 126\end{array}$

31.- Variação de pH na zona do Ayro Peru (área 1) 131 
32.- Variação de pH na zona de Charaña (área 2)

33.- Classificação hidrogeoquímica das águas, método Diagrama de Piper

34.- Classificação de águas para irrigação

35.- Diagrama logarítmico de potabilidade de água.

36.- Delimitação de zonas afetadas por exploração de águas superficiais.

37.- Modelo conceitual do reservatório da sub-bacia Uchusuma. 


\section{LISTA DE TABELAS}

1.- Localização da área de estudo segundo a divisão política do Peru, Bolívia e Chile

2.- Dados socioeconômicos e demanda de água do município de Tacna

3.- Ocupação do solo na agricultura no município de Tacna, Peru

4.- Localização das estações meteorológicas

5.- Sumário de parâmetros climáticos locais

6.- Dados de precipitação média de cinco estações meteorológicas

7.- Características pluviométricas no âmbito da área de estudo

8.- Registro da temperatura média mensal da estaçăo meteorológica de Charaña

9.- Variação térmica mensal

10.- Variação da umidade relativa na sub-bacia Uchusuma

11.- Dados de evaporação tanque tipo " $A$ "

12.- Estimativa de ETP a partir de dados de evaporimetro tanque tipo " $A$ "

13.- Estimativa de ETP por método de Thornthwaite

14.- Sumário de ETP calculados por diferentes métodos

15.- Coeficientes de correlação de ETP entre diversos métodos aplicados na bacia do lago Titicaca do Peru

16.- Balanço hídrico da sub-bacia do rio Uchusuma - método de Thornthwaite

17.- Dados de sondagem paramétrica para correlação e interpretação quantitativa

18.- Descargas diárias $\left(\mathrm{m}^{3} / \mathrm{s}\right)$ do rio Uchusuma periodo $2002-2003$

19.- Cadastramento de poços tubulares

20.- Cadastramento de fontes de águas superficiais 90

21.- Medidas de flutuaçőes do nível da água na zona de Ayro, Peru (área 1)

22.- Medidas de flutuações do nível da água na zona de Charaña, Bolívia (área 2) 100

23.- Avaliação das características técnica construtivas dos poços da zona de Ayro e Charaña

24.- Dados de teste de bombeamento

25.- Características técnicas dos poços de bombeamento e poço de observação 108

26.- Coeficientes de transmissividade do aqüifero Maure

27.- Parâmetros hidrodinâmicos determinados por INADE "Instituto Nacional de Desarrollo Tacna"

28.- Condutividade hidráulica do aqüifero Maure Capillune

29.- Coeficiente de armazenamento do aqüífero Maure Capillune

30.- Dados de vazão dos diferentes poços

31.- Capacidade produtiva dos poços tubulares profundos 
32.- Perfil da condutividade elétrica e pH observado no período 2000 a 2003, Ayro Peru

33.- Perfil da condutividade elétrica e pH observado no período 2000 a 2003, zona de Charaña, Bolívia

34.- Resultados de análises físico-químicas de águas, amostradas na zona do Ayro, Peru (área 1)

35.- Resultados de análises físico-químicas de águas, amostrados na zona do Charaña, Bolívia (área 2)

36.- Ocorrência de elementos tóxicos, zona de Charaña, Bolívia

37.- Normas de potabilidade

38.- Registro de volume de explotação de recursos hídricos da zona de Ayro, Peru 145 


\section{LISTA DE FOTOS}

1.- Perfil do vale do rio Uchusuma nas planicies de Visviri e Charaña, Bolívia 44

2.- Planície de Charaña e vulcâo Payachata, Bolivia 47

3.- Zona de planície e ladeira de montanha, Vilacollo, Peru

4 - Formação Sencca no Peru, Formação Pérez na Bolívia e Formação Oxaya no Chile

5.- Afloramento da Formação Sencca próximo ao rio Kaño, na Bolívia 57

6.- Depósitos fluvioglaciais na zona de Ayro Peru 63

7.-Depósitos fluvioglaciais no Peru, Formação Charaña na Bolívia e Formação Chiuchiu no Chile

8.- Características sedimentares da Formação Charaña na Bolívia

\section{ANEXOS}

1.- Dados de precipitação média mensal das estações meteorológicas: Paucarani, Peru, Charaña e Abaroa, Bolívia

11.- Perfil litológico dos Poços:PA-1, PA-2, PA- 3, PA- 4, PA- 5, PA- 6, PA- 7, PA-10, PCHALT

III.- Resultados de interpretação quantitativa de sondagens elétricas verticais (SEVs)

IV.- Dados de vazão de descarga média mensal do Rio Uchusuma, período 1963-1997 


\section{Resumo.}

A região litorânea sul do Peru e norte do Chile, convivem com um problema permanente de escassez de água por seu clima desértico. Esta carência hídrica limita o desenvolvimento sócio - econômico destas regiões, as quais são abastecidas por águas das bacias da região do Altiplano localizado na Cordilheira dos Andes. Historicamente, o município de Tacna - Peru é abastecido pelo rio Uchusuma do Altiplano com vazão $0,7 \mathrm{~m}^{3} / \mathrm{s}$. Porém, o desvio destas águas para o litoral Pacífico, tem provocado o ressecamento de algumas áreas úmidas, e levantado conflitos regionais de dimensões sociais, ambientais e políticas. Esta problemática, por outro lado, está relacionada à falta de conhecimento das potencialidades de recursos hídricos superficiais e subterrâneos existentes nas formações geológicas do Altiplano, especificamente na área estudada, sub-bacia do rio Uchusuma.

$\mathrm{Na}$ região observam-se extensos planaltos desenvolvidos sobre estruturas dobradas e subhorizontais que contrastam com a topografia abrupta da cadeia vulcânica. Estratigraficamente aflora uma seqüência vulcano-sedimentar do Terciário Superior ao Quaternário.

As características hidrogeológicas dessas áreas foram avaliadas utilizando-se imagem de satélite Landsat, métodos geofísicos, registros estratigráficos de poços profundos e testes hidrodinâmicos. A seqüencia sedimentar definida é composta por três unidades faciológicas: (i) em profundidade, encontra-se o aqüífero semi-confinado Maure, no Peru, ou Mauri, na Bolívia, constituída por sedimentos lacustrinos -fluviais intercalados por camadas vulcano sedimentares, com resistividades entre 42 ohm.m a 120 ohm.m; (ii) sobrepõem-se à formação anterior uma unidade de ignimbritos impermeáveis, denominados Formação Sencca, Pérez ou Oxaya no Peru, Bolivia e Chile, respectivamente, mostrando resistividades entre $110 \mathrm{ohm} . \mathrm{m}$ a $263 \mathrm{ohm} . \mathrm{m}$; e (iii) sobre esta unidade temos o aqüifero livre da Formação Capillune composta por sedimentos lacustrino fluvioglaciais, denominados na Bolívia de Formação Charaña, intercalados por camadas vulcano-sedimentares e aluviais recentes. Possuem resistividades entre 62 ohm.m a 95 ohm.m.

Os parâmetros hidrodinâmicos dos aqüíferos Maure e Capillune são: transmissividade $1959,5 \mathrm{~m}^{2} / \mathrm{dia}, 189,9 \mathrm{~m}^{2} / \mathrm{dia}$, capacidades especificas de 13,8 
$\mathrm{m}^{3} / \mathrm{h} . \mathrm{m}$ e $4,8 \mathrm{~m}^{3} / \mathrm{h} . \mathrm{m}$ respectivamente. As reservas reguladoras estimadas atingem $20,6 \times 10^{6} \mathrm{~m}^{3} /$ ano e as reservas permanentes de $932,3 \times 10^{6} \mathrm{~m}^{3}$ e uma vazão de oferta equivalente a $1,8 \mathrm{~m}^{3} / \mathrm{s}$.

A composição química das águas dos aqüíferos Maure e Capillune as classificam como bicarbonatadas cálcica e sulfatadas cálcicas, respectivamente. Na zona de Charãna, Bolívia, foi identificada a presença de arsênio em quantidades entre $0,034 \mathrm{mg} / \mathrm{L}$ a $0,231 \mathrm{mg} / \mathrm{L}$ que ultrapassam $0,01 \mathrm{mg} / \mathrm{L}$, limite permissível para 0 consumo humano.

Os resultados tem permitido desenvolver o modelo conceitual do comportamento dos aqüíferos locais e fornece a informação necessária para o gerenciamento de águas subterrâneas. 


\section{ABSTRACT}

The coastal regions of Peru and northern Chile constantly have to deal with a problem of water scarcity because of the arid climate. This water scarcity limits the socio-economic development of these regions which receive water from the Altiplano located in the Andes Ridge. Historically, the Tacna district in Peru is supplied by the Uchusuma River from the Altiplano with a runoff of $0.7 \mathrm{~m}^{3} / \mathrm{s}$. Yet, the deviation of these waters to the Pacific coast has resulted in the drying of humid areas and in regional conflicts of social, environmental and political dimensions. On the other hand, this problem is related to the lack of knowledge regarding the surface and underground water resources potential in the Altiplano geological formations, specifically in the surveyed area, that is, the Uchusuma River sub-basin. There are extensive plateaus in the region that developed over folded structures and sub horizons which contrast with the abrupt topography of the volcanic ridge. A volcano-sedimentary sequence arises stratigraphically from the Superior Tertiary to the Quaternary.

The hydrogeologic characteristics of these areas were evaluated through Landsat satellite imagery, geophysical methods, stratigraphic registries of deep wells and hydrodynamic tests. The defined sedimentary sequence is composed of three facies: (i) the deep semi-confined aquifer Maure in Peru or Mauri in Bolivia is composed of sediments of the lacustrine type - fluvial intercalated with volcanosedimentary horizons with resistivity ranging from $42 \mathrm{ohm} . \mathrm{m}$ to $120 \mathrm{ohm} . \mathrm{m}$; (ii) above the previous layer is a confining layer of fractured ignimbrites called Sencca Formation in Peru, Pérez Formation in Bolivia or Oxaya Formation in Chile with resistivity ranging from $110 \mathrm{ohm} . \mathrm{m}$ to $263 \mathrm{ohm} . \mathrm{m}$, and (iii) above this layer is the unconfined aquifer of the Capillune Formation, composed of lacustrine-fluvioglacial deposits, intercalated by recent volcano-sedimentary and alluvial horizons called Charaña Formation in Bolivia with resistivity ranging from $62 \mathrm{ohm} . \mathrm{m}$ to $95 \mathrm{ohm} . \mathrm{m}$.

The hydrogeologic parameters of the aquifers Maure and Capillune are: transmissivity $1959.5 \mathrm{~m}^{2} /$ day and $189.9 \mathrm{~m}^{2} /$ day, and specific capacity of 13.8 $\mathrm{m}^{3} / \mathrm{h} . \mathrm{m}$ and $4.8 \mathrm{~m}^{3} / \mathrm{h} . \mathrm{m}$ respectively. The estimated regulating reserves reach $20.6 \times 10^{6} \mathrm{~m}^{3} /$ year and the permanent reserves are of $932.3 \times 10^{6} \mathrm{~m}^{3}$ and a supply flow equivalent to $1.8 \mathrm{~m}^{3} / \mathrm{s}$. 
The chemical composition of waters the aquifer of Maure is classified as calcium bicarbonated and the aquifer of Capillune is classified as calcium sulfated. In the Charâna - Bolivia zone, arsenic was found in a concentration range of $0.034 \mathrm{mg} / \mathrm{L}$ to $0.231 \mathrm{mg} / \mathrm{L}$ that exceeds the human consumption limit of $0.01 \mathrm{mg} / \mathrm{L}$.

The results have allowed to develop the conceptual model of the behavior of the aquifers places and supply the necessary information the groundwater management 


\section{CAPITULO I}

\section{INTRODUÇÃO.}

\subsection{0 - Apresentação da Área de Estudo}

$\mathrm{Na}$ latitude $16^{\circ}$ a $19^{\circ} \mathrm{Sul}$, uma ampla região do litoral do Pacífico sul apresenta um clima desértico. Nestas áreas encontram-se localizados vários municípios do Peru e do Chile, que convivem com um problema permanente de escassez de recursos, hídricos limitando o desenvolvimento sócio - econômico destas cidades. O abastecimento de água para estas áreas de escassez hídrica, como Tacna e Moquegua do Peru, $52 \%$ das demandas é providenciado por fontes localizadas dentro do município e o restante $(48 \%$ ) por recursos hídricos das bacias da Região Altiplánica da Codilheira Ocidental dos Andes (Ministério Agricultura 1999), onde as características hidrogeológicas oferecem melhor renovabilidade sazonal. O desvio destas águas para as bacias do litoral do Pacífico tem provocado regionalmente, conflitos sociais, ambientais e políticos entre a população rural, desprotegida do Altiplano e empresas de abastecimento de água e governantes dos países envolvidos nesta problemática

Geograficamente, as bacias provedoras de água para o litoral Pacífico pertencem ao sistema hídrico fechado da bacia regional do Altiplano, localizado na faixa central das cordilheiras Oriental e Ocidental dos Andes meridionais da América do Sul, cuja extensão abrange os territórios do Peru, Bolívia, Chile e Argentina (FIGURA 10, p: 38)

Segundo os índices pluviométricos da macro região do Altiplano, variam de 1100 $\mathrm{mm}$ /ano registrados nas zonas Norte do Lago Titicaca, a menos de $200 \mathrm{~mm} / \mathrm{ano}$ nas zonas Sudeste do Altiplano (Cordilheira Ocidental e Bacia Salar de Uyuni), com ETP entre $1500 \mathrm{~mm} / \mathrm{ano}$ a $2000 \mathrm{~mm}$ /ano na respectivas zonas (MIRANDA et al., 2000). Dentro desta região, a área de pesquisa localizada no Altiplano ocidental, caracteriza-se por seu clima frio e seco com escassa precipitação de $331 \mathrm{~mm} / \mathrm{ano}$, observando-se freqüentemente a ocorrência de anos de intensa seca, com precipitações inferiores a $250 \mathrm{~mm} /$ ano. 
De modo geral o problema de escassez de água afeta uma grande região do sul do Peru, onde estão assentadas várias comunidades dispersas no altiplano e cidades do litoral pacífico do Peru. Esta situação implica encontrar soluções particulares para atender às demandas atuais e futuras de desenvolvimento sócio-econômico. Uma resposta para a problemática apresentada conduz a prospeção e avaliação integral dos recursos hídricos subterrâneos desta região. Atualmente cada pais como Bolívia e Chile vêm promovendo programas de prospeção, explotação de águas superficiais e subterrâneas de modo unilateral para atender suas próprias necessidades. Este processo não está acompanhado de um plano de gerenciamento global das bacias de domínio internacional.

Os antecedentes descritos brevemente, revelam em parte a problemática regional, assim como as expectativas ligadas às águas subterrâneas como recurso estratégico no desenvolvimento das cidades da fronteira. Neste sentido, os resultados do presente trabalho visam a contribuir com os elementos necessários para estabelecer as bases para um plano de gerenciamento da subbacia do rio Uchusuma.

\subsection{0.- Objetivo geral}

Pesquisar as características sedimentares de aqüiferos em formações pliocênicas que ocorrem no âmbito da sub-bacia do rio Uchusuma localizada na região timítrofe dos países do Peru, Bolívia e Chile

Estimar as reservas disponiveis dentro dos limites da sub-bacia, que sirvam de base para o planejamento de gestão dos recursos hídricos e possibilite um aproveitamento sustentável, para atender as demandas locais e regionais que dependem das águas da sub-bacia do rio Uchusuma.

\subsection{1.- Objetivo específico}

- avaliar as características gerais de armazenamento de águas subterrâneas em depósitos vulcano sedimentares.

- determinar o modelo de circulação da água subterrânea em função da morfologia e geometria do aqüifero. 
- avaliar a qualidade das águas subterrâneas em função das características litológicas da área de pesquisa.

- realizar um diagnóstico dos problemas ambientais gerados por desvio das águas do Altiplano para o litoral pacífico.

\subsection{0.- Localização da área de estudo}

A área de estudo (FIGURA 1, p: 4) encontra-se localizada na zona limítrofe do Peru, Bolivia e Chile, a uma altitude entre 4050 a $4600 \mathrm{~m}$. Na TABELA 1 apresenta-se uma localização específica segundo a demarcação política dos respectivos países.

TABELA 1 - LOCALIZAÇÃO DA ÁREA DE ESTUDO SEGUNDO A DIVISÃO POLITICA DO PERU, BOLIVIA E CHILE.

\begin{tabular}{ccccc}
\hline País & Departamento/ Região & Provincia & Distrito/sección & Povoado ou Canton \\
\hline Peru & Tacna & Tacna & Palca & Ayro \\
Bolívia & La Paz & Pacajes & 5ta.Charaña & Charaña \\
Chile & Tarapacá & Parinacota & General Lagos & Visviri \\
\hline
\end{tabular}

A área de estudo abrange uma superfície, de contorno irregular, de $624 \mathrm{Km}^{2}$ aproximadamente, limitada pelas seguintes coordenadas UTM:

$\begin{array}{lrr}\text { LATITUDE } & 8046,000 & 8072,000 \\ \text { LONGITUDE } & 404,000 & 458,000\end{array}$

O rio Uchusuma constitui um dos tributários do rio Maure, localizado no Altiplano ocidental, que desemboca no rio Desaguadero, componente da grande bacia do sistema regional Titicaca, Desaguadero, Poopó e Salar de Coipasa, conhecido como sistema TDPS.

A área de estudo é acessivel por diferentes vias de cada pais:

- no território boliviano, estrada cidade La Paz, Berenguela a Charaña, ou Cidade La Paz, Challapata, Sajana, Rio Blanco, Charaña.

a no Peru, estrada cidade de Tacna, Alto Peru, Ayro.

no Chile: via ferroviaria Arica, localidade de Visviri, 
FIGURA 1 - LOCALIZAÇÃO DA ÁREA DE ESTUDO

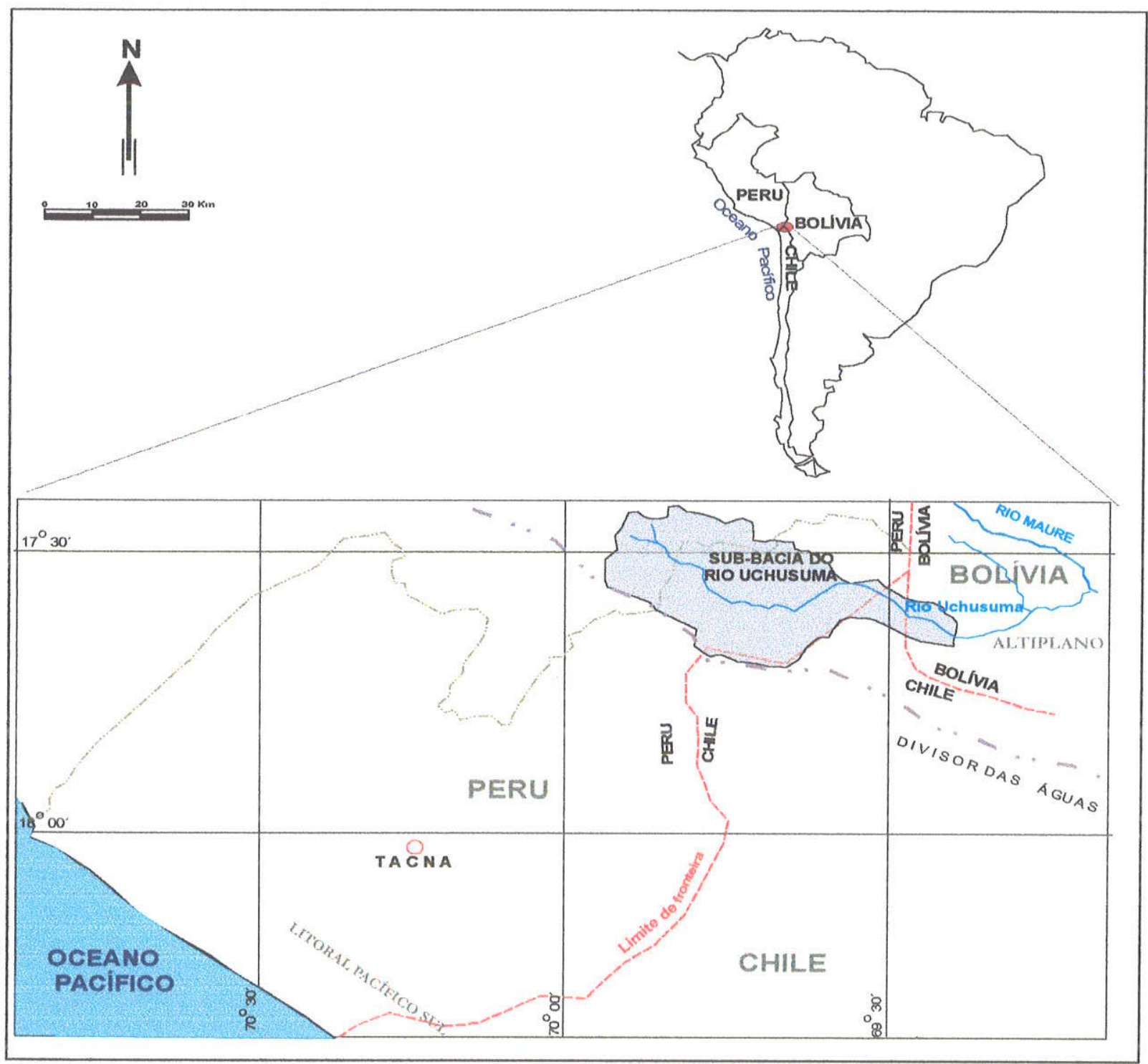

FONTE : Ministerio de Transportes y Comunicaiones -2002

\subsection{0.- Conflito sobre às águas superficiais na região}

A crescente demanda de água dos setores produtivos como a agricultura, industria e serviço de abastecimento a centros urbanos, e por outra parte, o problema de escassez de água que afeta uma vasta região do litoral pacífico sul e zonas de escassa precipitação do Altiplano, é sobejamente conhecido nos países no Peru, Bolívia e Chile. A problemática da escassez de água é bastante sentida na região do litoral desértico, e esta condição negativa tem levado seus habitantes à busca de fontes alternativas de abastecimento em regiões ou bacias 
adjacentes como no Altiplano da Cordilheira Ocidental dos Andes. Estas áreas mostram um regime pluviométrico mais favorável quando comparado com o do litoral, possibilitando o armazenamento de águas subterrâneas e fluxo de águas superficiais, destacando-se alguns rios por seu regime permanente.

Do ponto de vista econômico, observa-se que as águas dos rios do Altiplano não são eficientemente aproveitadas, não existindo um plano de gerenciamento sobre estas águas. Na maioria dos casos, só conservam as áreas hidromórficas que estão ligadas à produção pecuária de comunidades camponesas do Altiplano peruano e boliviano, e o volume excedente perde-se por evaporação ao longo do seu deslocamento às regiões das salinas de Coipasa e Uyuni. Observando este fato, os municípios da região do litoral vêm explotando no altiplano tanto as águas superficiais como as subterrâneas, para atender as demandas dos setores econômicos produtivos, fundamentalmente para a irrigação de zonas com grande potencial agrícola existentes no litoral pacífico sul.

Entre os rios do Altiplano com um regime de fluxo permanente, segundo os dados da instituição Autoridad Binacional Autónoma de la Cuenca del Sistema TDPSBolivia, destacam-se:

rio Maure, com uma vazão de fluxo $35,00 \mathrm{~m}^{3} / \mathrm{seg}$;

rio Kaño, vazão de fluxo de $0,23 \mathrm{~m}^{3} / \mathrm{seg}$;

rio Uchusuma, vazão de fluxo $1,60 \mathrm{~m}^{3} / \mathrm{seg}$.

A derivação dos rios que nascem na vertente oriental da Cordilheira Ocidental dos Andes para as zonas desérticas do litoral Pacífico do Peru, representa social e politicamente uma demanda e imposição de interesse de desenvolvimento sócio econômico dos municípios de Tacna, Moquegua e Arequipa. Estas zonas litorâneas constituem uma das áreas econômicas mais importantes do sul do Peru, cujo desenvolvimento tem-se atrasado, notavelmente por falta de disponibilidade de água, limitando severamente o impulso de planos de inversão e expansão da zona franca da cidade de Tacna e da própria Bolivia.

Em 1979 PEREZ fez estimativa da demanda de água para o ano 2000 da cidade de Tacna, determinando um volume de $1 \mathrm{M}^{3} / \mathrm{s}$ para uma população projetada de 
80.000 habitantes. Atualmente a população desta cidade é de 234.508 habitantes (INEI 1994), com uma demanda de água para o consumo doméstico e irrigação de $22,54 \mathrm{~m}^{3} / \mathrm{s}$ PET-INADE (1999). De outro lado, os habitantes da região do altiplano de condição sócio-econômica subdesenvolvida e com alto nível de pobreza, desde o início de projetos de derivação das águas para o litoral, vêm realizando demandas e movimentos a nivel internacional em defesa dos recursos hídricos do altiplano. Segundo o Jornal PRESENCIA, 06-12-2000, a derivação das águas para o litoral tem ocasionado a perda de 600 hectares de áreas úmidas, produtoras de vegetação nativa para a atividade pecuária na zona de Charaña. Entre outros, nesta problemática também estão associados aspectos climáticos desfavoráveis para a prática da agricultura, devido ás baixas temperaturas e condições de semi - aridez. Esta situação dos povos do Altiplano tem sido ao longo dos anos uma das razões da defesa das suas águas.

No conflito hídrico regional, o problema social aparece como um componente muito determinante na defesa das águas do altiplano, envolvendo diferenças físicas, sociais, culturais, institucionais e políticas entre áreas geográficas em desenvolvimento e zonas com alto nivel de pobreza.

TABELA 2 - DADOS SOCIOECONÔMICOS E DEMANDA DE ÁGUA DO MUNICIPIO DE TACNA.

\begin{tabular}{|c|c|c|c|c|c|}
\hline \multicolumn{4}{|c|}{$\begin{array}{c}\text { SITUAÇÄO SOCIOECONÓMICA } \\
\text { Fte. INEI (1993) }\end{array}$} & \multicolumn{2}{|c|}{$\begin{array}{c}\text { OFERTAS E DEMANDAS DE AGUA } \\
\text { Fte. PET-INADE } 1999 .\end{array}$} \\
\hline Milhes de habitantes & 2000 & $\%$ crescimento & $\begin{array}{l}\text { Projeção } \\
\text { ano } 2020\end{array}$ & Variáveis & $\mathrm{M}^{3} / \mathrm{s}$ \\
\hline População total & 243.379 & $3,0 \%$ & 532.978 & Demanda hídrica & 22,54 \\
\hline Urbana & 234.508 & $4,0 \%$ & 513.573 & Oferta de água & 12,04 \\
\hline \multirow[t]{2}{*}{ Rural } & 88.611 & $1,0 \%$ & 194.058 & Déficit hidrica atual & 10,5 \\
\hline & & & & Déficit hídrica ano 2010 & 18,1 \\
\hline PEA & 135.557 & & 296.870 & & \\
\hline Emprego & 81.198 & $1,6 \%$ & 177.824 & & \\
\hline Subemprego & 42.023 & $1,6 \%$ & 92.030 & & \\
\hline Afastado sem emprego & 12.336 & $1,1 \%$ & 27.016 & & \\
\hline
\end{tabular}


TABELA 3 - OCUPAÇÃO DO SOLO NA AGRICULTURA NO MUNICIPIO DE TACNA. - PERU

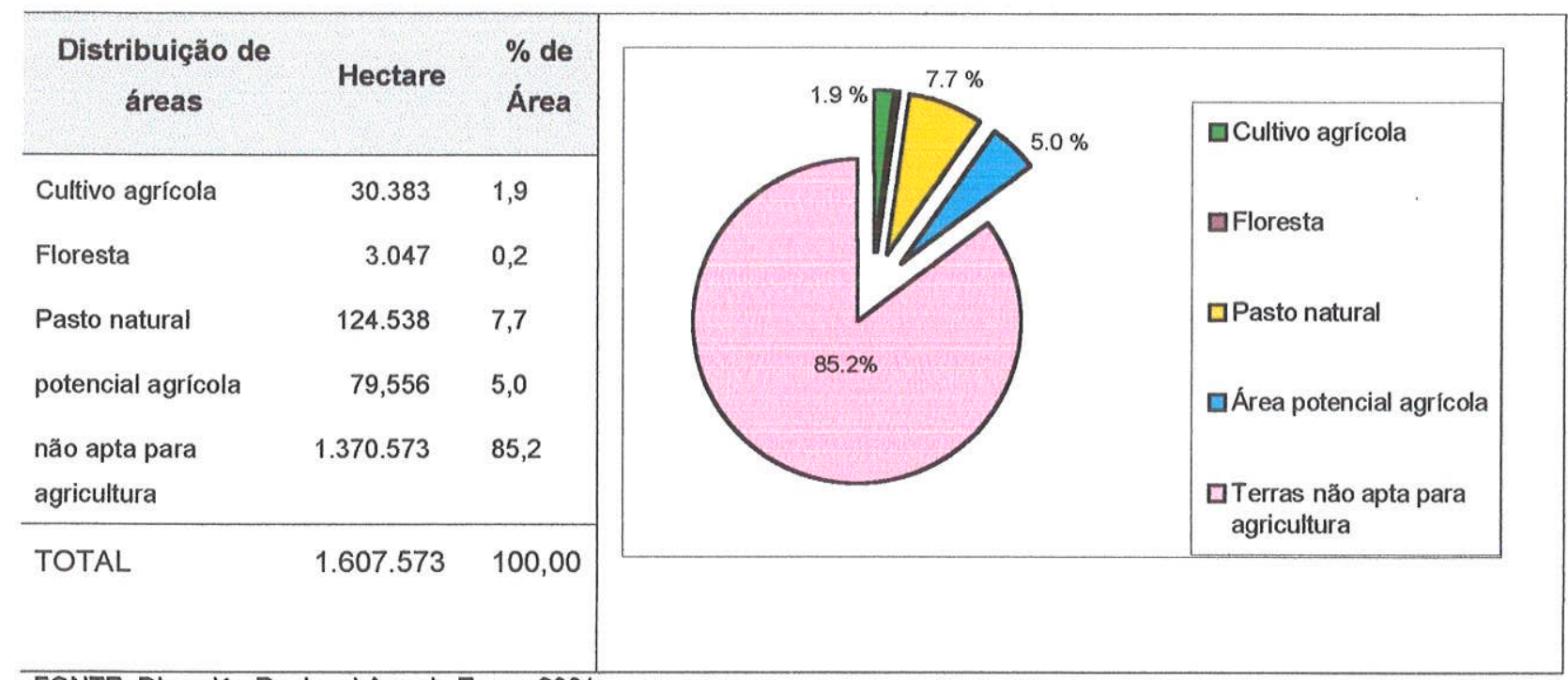

FONTE: Dirección Regional Agraria Tacna 2001

\subsection{0.- Histórico de projetos de derivação de águas do Altiplano para o litoral Pacífico}

O problema do conflito pela derivação das águas do Altiplano para o litoral pacífico, segundo nota do jornal do Parlamento Aymara (1999), data desde os anos 1860. Os acontecimentos mais importantes segundo o Jornal PRESENCIA, dias 4 e 6 Dezembro 2000, La Paz, IICA (Instituto Internacional de Cooperación para la Agricultura - IICA) são:

- Projetos de desvio das águas do Altiplano executados pelo governo chileno

1914 desvio das águas do rio Silala para o litoral Pacífico, vazão 200 L/s.

1915 desvio das águas do rio Uchusuma para o vale de Tacna, uma vazão de $500 \mathrm{~L} / \mathrm{s}$, através do túnel transandino Waylillas, construído no período de ocupação do território peruano por chilenos.

1962 Desvio das águas do rio Lauca, vazão $3 \mathrm{~m}$ /s, através da construção do Il túnel transandino de Chapiquiña.

Entre outros rios do altiplano que foram desviados estão: Cajón, Torito, Queñua, Q'ocha, Ollaque, Olka Pusuta, Cabaray e Macaya.(Comisión para la Cooperación Ambiental CCA, 1997) 
Futuros projetos de desvio das águas:

Rio Caquena ou Cosapilla $12 \mathrm{~m}^{3} / \mathrm{s}$.

Rio Putani $0,46 \mathrm{~m}^{3} / \mathrm{s}$.

Rio Achuta. $0,86 \mathrm{~m}^{3} / \mathrm{s}$.

Exploração das águas subterrâneas do Parque Nacional de Lauca, mediante 7 poços profundos.

- Projetos de desvio das águas do Altiplano executados pelo governo peruano.

1929. Após a devolução de territórios ocupados pelo Chile, o governo peruano implementou novos projetos de desvio das águas do rio Maure para atender às necessidades do município de Tacna.

1936 - 1954 realizou-se estudos de engenharia para desviar 100\% das águas do rio Uchusuma para o litoral.

1981-86 construiu-se a barragem da lagoa Paucarani.

Em 1978 implementou-se o projeto de captação de águas subterrâneas no Altiplano mediante a perfuração de 13 poços profundos nas planícies da localidade do Ayro, Peru (zona limitrofe com Bolívia - território Aymara)

1990. reiniciaram-se trabalhos de captação do rio Maure mediante dois sistemas: por gravidade e por bombeamento.

1994. iniciou-se a construção do Túnel transandino de Kovire de $8,5 \mathrm{~km}$ de extensão por $10 \mathrm{~m}$ de largura, e a construção de um canal coletor de vários córregos afluentes do lago Titicaca e rio Desaguadero.

Os antecedentes descritos brevemente, revelam em parte os antecedentes do conflito da água na região limítrofe do Peru, Bolívia e Chile:

- Projetos de aproveitamento de recursos hídricos pelo governo boliviano.

$\mathrm{Na}$ faixa da jurisdição boliviana, o aproveitamento de água subterrânea é bastante incipiente ou limitado, embora nos últimos anos o interesse seja 
bastante grande por utilizar todo o recurso hídrico das bacias limitrofes para o desenvolvimento sócio-econômico dos povos bolivianos. Entretanto, o único projeto de captação de águas subterrâneas fol realizado em 1978 pela Corporación de Água Potable y Alcantarillado (CORPAGUAS), para abastecer o povoado de Charaña aproveitando-se uma vazão de $5,4 \mathrm{~m}^{3} / \mathrm{h}$ a $7,2 \mathrm{~m}^{3} / \mathrm{h}$. No ano 2000 , com o intuito de melhorar o serviço, foi perfurado na localidade de Charaña um poço de $200 \mathrm{~m}$ de profundidade, financiado pela Autoridad Binacional de Lago Titicaca (ALT). A vazão de produção não ultrapassa os 36 $\mathrm{m}^{3} / \mathrm{h}$

Segundo nota do Jornal "PRENSA de 17 de novembro de 2000", o "Servicio Geológico Minero Boliviano", com apoio da Agência de Cooperação do Governo do Japão (JICA), vem implementando o projeto de avaliação dos recursos hídricos na região de fronteira com o Chile.

\subsection{0.- Justificativa para escolha da área de estudo.}

A escolha da bacia do rio Uchusuma deveu-se às seguintes causas:

- a preocupação com a problemática sócio-ambiental gerada por uma falta de cooperação na gestão das bacias hidrográficas transfronteriças da região do Altiplano. O problema não é simples, pois muitas condicionantes estão envolvidas neste assunto tais como: extensão da linha de fronteira; diferenças sócio-econômicas; e culturais, e políticas de desenvolvimento de zonas de fronteira empreendidas por paises limítrofes.

- no altiplano reside umas das áreas com melhores possibilidades de oferta de recursos hídricos nesta região semi árida, onde é necessário conhecer os limites de suporte das bacias transfronteriças para serem exploradas em termos técnicos, sócio-econômicos e ambientais, que permitam planejar, gerenciar e atingir os objetivos do desenvolvimento sustentável.

- políticas predatórias na explotação das águas superficiais e subterrâneas por cada um dos países, com grandes diferenças em termos quantitativos. 
- ameaça de eventos críticos, como anos de seca prolongada, que podem engendrar efeitos dramáticos sobre a economia , a saúde e a segurança das comunidades camponesas do Altiplano.

- Carência de estudos hidrogeológicos das diferentes sub-bacias do altiplano. 


\section{CAPITULO II}

\section{METODOLOGIA}

\subsection{0.- Divisão da área de pesquisa}

Com o intuito de apresentar uma descrição localizada das características hidrogeológicas da área de pesquisa e, em concordância com os propósitos do estudo, extensão da área $624 \mathrm{~km}^{2}$ e características morfoestruturais do Altiplano, dividiu-se o âmbito territorial de estudo em duas áreas seguindo a demarcação de limite de fronteira entre Peru e Chile (FIGURA 18, p: 73). A área 1, abrange uma zona de maior extensão localizada no território peruano, onde encontram-se as planícies de Ayro, Vilacollo, zonas altas da lagoa Paucarani; a área 2 localiza-se a jusante da sub-bacia e abrange as planícies de Charaña Pampa no Chile, e planície do povoado de Charaña na Bolivia.

Para o desenvolvimento dos trabalhos de pesquisa e levantamento de dados de campo, planejou-se um roteiro de atividades com a finalidade de obter uma informação mais criteriosa e melhor compreensão dos componentes pesquisados ou monitorados, tais como: aspectos físicos, geométricos e padrões de funcionamento do sistema aqüífero local. Em cada fase de trabalho, utilizaram-se tanto métodos diretos como indiretos, em concordância com os objetivos propostos. Os detalhes destas atividades são apresentados e discutidos em conjunto com os métodos de desenvolvimento da pesquisa nos diversos capítulos a seguir.

\subsection{0- Campo de pesquisa}

Os trabalhos de pesquisa foram orientados para a avaliação das formações pliocenicas-quaternarias presentes na sub-bacia do rio Uchusuma. Esta seqüência, na zona meridional do Peru, constitui um dos aspectos geológicos mais discutidos pela complexidade da sua ocorrência e eventos geológicos que acompanharam as últimas etapas de evolução da Cordilheira dos Andes. (MENDIVIL, 1977) 
Na cordilheira Ocidental dos Andes é evidente o predomínio de rochas vulcânicas e formações sedimentares de ambiente lacustrino constituído por materiais vulcânicos redepositados que afloram acima dos $4000 \mathrm{~m}$ de altitude.

Dentro desta complexidade, observou-se que as formações vulcâno-detriticas e depósitos vulcano-sedimentares plio-quaternários, apresentam, em sua seqüência estratigráfica, formações de interesse hidrogeológico pela natureza de seus componentes litológicos, propriedades hidráulicas, características litoestratigráficas, formas de ocorrência e distribuição regional; estes atributos definiram a amplitude e enfoque do campo de pesquisa, centrando-se os estudos na Formação Maure e Formação Capillune de idade Mioceno-Plioceno e depósitos quaternários recentes.

No panorama descrito os trabalhos de pesquisa destinaram-se à avaliação das características gerais de armazenamento, fluxo, qualidade das águas, formas de ocorrência, e quantificação do potencial de águas subterrâneas.

\subsection{0.- Pesquisa da documentação existente e validação dos estudos anteriores}

Foram recopilados trabalhos científicos, técnicos, sociais, econômicos, cartográficos, hidrogeológicos referentes às águas subterrâneas no Altiplano, com enfoque na região limitrofe do Peru, Bolívia e Chile.

A revisão da literatura técnica científica teve por finalidade conceituar zonas já exploradas e agrupar dados básicos necessários sobre o conhecimento da situação atual da sub-bacia. A esta informação foram correlacionados novos dados de campo de áreas não pesquisadas, dando ênfase à caracterização das formações geológicas presentes na área delimitada. Assim, foram revisados 13 relatórios desenvolvidos por diferentes instituições do Peru e Bolívia, cuja análise da evolução dos conhecimentos encontra-se no item 2.3.1.

O nivel de detalhe do estudo foi determinado com base nos objetivos da pesquisa e extensão da sub-bacia, definindo-se desenvolver trabalhos na escala 1:50.000. Com esta finalidade elaborou-se uma base planialtimétrica para o levantamento de dados geológicos hidrogeológicos, correlação de dados estratigráficos, 
monitoramento de pontos de controle de águas subterrâneas e análises e interpretação de dados levantados. O resumo dos dados analisados e interpretados foram transferidos em mapas na escala 1:100.000.

Outras informações básicas de referência utilizadas foram:

- mapa geológico do Instituto Geológico Minero Metalúrgico (INGEMMET) do Peru, a escala 1:100.000, das seguintes folhas:

- $35 \times$ Folha MAURE (INGEMMET, 1998)

- $36 \times$ Folha PALCA (INGEMMET, 1998)

- 35 Y Folha ANTAJAVE (INGEMMET, 1998)

- mapa geológico do Servicio Nacional de Geología y Minería SERGEOMIN, Bolivia ex-instituição "Departamento Nacional de Geología da Bolivia". Folha CHARAÑA (Montes de Oca et al. 1963).

- mapa geológico do Servicio Nacional de Geología y Minería SERNAGEOMIN, Chile. Región de Tarapacá.

- imagem de satélite LANDSAT, bandas 7,4,2, do ano 1995. Região de Maure. Fronteira do Peru, Bolivia e Chile Escala 1:100.000.Coordenadas: 8 036.000 a 8080.000 Norte e 388.000 e 470.000 Leste.

- imagem de satélite LANSAT, monocromática, do ano 1995. Região de Maure. Fronteira do Peru, Bolívia e Chile. Escala 1:100;000 Coordenadas: 8036.000 a 8080.000 Norte e 388.000 e470.000 Este

\subsection{1. - Revisão da literatura}

Problemas de escassez dos recursos hídricos no litoral Pacífico, como as grandes demandas dos setores produtivos dos município de Tacna, Moquegua do Peru, têm sido fatores determinantes que conduziram ao desenvolvimento de projetos de derivação das águas da região do Altiplano para as bacias do litoral de Pacífico Sul. 
De acordo com a informação bibliográfica compilada encontrou-se diversos relatórios de prospeção de águas subterrâneas e resultados de perfuração de poços profundos executados por Instituições peruanas na zona do Ayro Peru. Estes trabalhos assentaram as bases do desenvolvimento do trabalho de pesquisa.

Dentre os trabalhos mais antigos destaca-se, por sua relevância, os estudos realizados pela instituição Direção de Industria e Eletricidade Tacna, trabalho intitulado "Esquema de Aprovechamiento de las Aguas del rio Maure", executado por MEGAR (1961), para atender as demandas do município de Tacna - Peru. Neste relatório descreve-se a estratigrafia e hidrologia da bacia do rio Maure que pertence ao sistema fluvial fechado do rio Desaguadero Lago Poopó, e propõe a possibilidade de aproveitamento parte das águas superficiais para 0 desenvolvimento da região litoral, departamento de Tacna - Peru.

No início dos anos 1970, a expansão da agricultura no municipio de Tacna apresentou uma demanda de $1260 \mathrm{~m}^{3} /$ h. Frente a esta problemática, o Ministerio da Agricultura realizou trabalhos de prospeção no Altiplano (Pampas del Ayro), determinando a presença de um aqüífero de extensão regional, reconhecido como Formação Maure de idade pliocênica, com características hidrogeológicas similares à Formação Capillune, que abastece as demandas hídricas dos produtores agropecuários do vale de Moquegua-Peru (região litorânea). Nesse relatório, PÉREZ (1974) descreve algumas características do aqüifero Maure, constituído por materiais vulcânicos sedimentares depositados em ambiente lagunar.

Em 1974 a antiga instituição Dirección General de Aguas do Ministerio de Agricultura do Peru, realizou outros trabalhos preliminares de prospecção hidrogeológica nas planícies de Vilacollo, Tacna. Os resultados determinaram a ocorrência da Formação Maure nesta área com características aqüiferas similares às encontradas pela Empresa de Mineração Soutern Peru Cooper Corporation nos afloramentos do Altiplano do departamento de Moquegua, zona Norte de Tacna, e propõem áreas favoráveis para perfuração de poços exploratórios 
Com base em resultados anteriores, entre 1977 e 1998 foram perfurados treze poços profundos, cuja produção atinge $1.789 \mathrm{~m}^{3} / \mathrm{h}$ em forma permanente.

Com o crescimento progressivo das cidades assentadas no litoral peruano, gerouse uma maior demanda de água para o setor da agricultura, industria e para atender às necessidades da central hidroelétrica de Vilavilani. Em 1993 o Proyecto Especial de Afianzamiento y Ampliación de los Recursos Hidricos de Tacna, realizou estudos de prospeção no Altiplano da Cordilheira dos Andes, nas áreas de El Ayro, Vilacota e Viscachas para incrementar o bastecimento de água para a região litorânea. As conclusões do estudo assinalaram a presença de um conjunto de aqüiferos com características de confinado e semi-confinado, limitados por formações vulcânicas de idade Terciario superior a Quaternário.

Posteriormente no ano 1997 o Proyecto Especial Tacna (PET) realizou diversos trabalhos de prospeção em diferentes localidades do Altiplano, zona Cordilheira Ocidental dos Andes e áreas vizinhas das localidades de Kallapuma, sub-bacía de Ancomarca, Uchusuma, que constituem os tributários da bacia do rio Maure. Os estudos aprofundaram em parte o conhecimento das características geológicas e hidrogeológicas desta zona.

$\mathrm{Na}$ área boliviana poucos trabalhos foram identificados em assuntos de pesquisa de águas subterrâneas do Altiplano boliviano. Porém, destacam-se por seu interesse:

Estúdio Geológico - Zona de Charaña; Estación Abaroa ; La paz Bolívia por NUÑEZ (1964), foi o primeiro trabalho realizado como tema de tese apresentada à Universidade de San Andrés, Bolívia. O trabalho é de interesse estratigráfico regional, e descreve as diferentes unidades litoestratigráficas que ocorrem na zona baixa da bacia do rio Uchusuma e seu entorno.

BLANCO (1980) realizou estudo Geológico intitulado Evoluçión Plio Cuaternaria de la Cuenca Charaña. O autor realiza uma interpretação da evolução sedimentar, paleohidrológica e paleoclimática da bacia de Charaña.

Em 1998 a Autoridad Binacional del Sistema Hidrico del lago Titicaca, Rio Desaguadero, Lago Poopó, Salar de Coipasa (TDPS), com fins de abastecimento 
de água ao povoado de Charaña, fizeram estudos de prospeção geofísica na zona baixa da sub-bacia do rio Uchusuma para perfuração de um poço tubular profundo. Os resultados do trabalho evidenciaram a presença do aqüifero Maure, que se projeta desde o território peruano, com grandes possibilidades para a exploração de águas subterrâneas.

No ano de 1998 a instituição "Autoridad Binacional del Sistema Hídrico del Lago Titicaca, Rio Desaguadero, Lago Poopó, Salar de Coipasa" (TDPS), realizou na zona baixa da bacia do rio Maure uma avaliação preliminar da qualidade das águas superficiais, salientando o problema de contaminação natural dos rios e zonas úmidas por águas de origem hidrotermal de numerosos mananciais que afloram na zona da Cordilheira Ocidental dos Andes.

No território chileno não se conhece trabalhos específicos realizados dentro da área de interesse do estudo, mas é possivel que existam estudos de aproveitamento das águas do Altiplano da Cordilheiras Ocidental dos Andes para abastecer a zona do litoral chileno. Economicamente, a agricultura na região norte do Chile constitui a principal atividade, e os problemas de escassez e demanda de água destas zonas são similares às do Peru.

\subsection{0.- Cadastramento de pontos de água}

Fontes de água superficial, nascentes, captações de água subterrânea foram cadastradas, codificadas e localizadas no mapa 1:50.000 e 1:100.000. Para esta atividade elaborou-se um registro de levantamento de informações, tais como: localização do ponto da água, características técnicas construtivas dos poços, ano de perfuração, perfil litológico das sondagens, regime de explotação, vazão, níveis de água, e qualidade de água.

Na FIGURA 26, (p: 89) e TABELA 19, 20, (P: 90, 91) apresenta-se dados coletados nos pontos de água cadastrados.

\subsection{0.- Instalação de poços de observação}

Em áreas de escassa informação hidrogeológica, como a zona de Charaña, Bolívia, foram instalados 07 poços de observação, com a finalidade de monitorar 
as variações do nivel de água e realizar amostragem para determinar a qualidade das águas, etc. As profundidades dos poços não ultrapassam os $14 \mathrm{~m}$.

\subsection{0.- Potenciometria}

Foram realizadas campanhas de medição da variação sazonal do nivel da água na rede de poços de monitoração referenciados à cotas topográficas. O período de observação começou no mês de outubro de 2000 e terminou no mês de março de 2003.

Com base da informação coletada foram elaborados mapas potenciométricos para diferentes épocas de observação, com a finalidade de determinar o comportamento de fluxo do aqüífero livre, variações sazonais, mapas hidroquímicos, os quais são apresentados e discutidas nos respectivos capítulos.

\subsection{0.- Explorações geofísicas}

Os métodos geofísicos permitem a pesquisa dos litotipos e estruturas favoráveis ao acúmulo e circulação das águas subterrâneas. Tendo em vista a obtenção de informação básica das formações aqüiferas como: extensão e natureza das camadas, variação lateral e vertical das litofacies, espessura e posicionamento do aqüífero, foi utilizado o método geofísico da resistividade elétrica em uma quantidade de 104 SEVs, das quais 51 SEVs foram implementadas na fase de pesquisa, em quanto que as restantes (53 SEVs) correspondem a dados selecionados e reinterpretados de trabalhos de sondagens executados no período 1974 a 1990 pela instituição Proyecto Especial de Tacna. Esta quantidade de pontos de sondagem encontram-se distribuídas em toda a área de pesquisa.

O método de resistividade elétrica é amplamente conhecido na pesquisa de águas subterrâneas, e em conseqüência, é uma ferramenta de grande ajuda na caracterização de aqüíferos como definida por ASTIER, (1975); PARASNIS, (1986). Com os dados coletados foram elaborados diferentes perfis que permitiram definir a espessura da Formação Maure, camada de ignimbritos denominados Formação Sencca, Pérez ou Oxaya, Formação Capillune, Formação Charaña ou fluvio glacial e suas características morfológicas. Os resultados são apresentados com precisão no capítulo de geofísica. 


\subsection{0.- Análise sedimentar das formações aqüiferas}

As características sedimentares do aqüífero semiconfinado Maure e aqüifero livre Capillune, foram definidas com dados de registro litológico de sete poços profundos localizados na área $1 \mathrm{e}$ um poço de $200 \mathrm{~m}$ de profundidade perfurado durante a fase de pesquisa (ano 2000) na área 2. Estes dados foram correlacionados com registro dos diferentes poços e comparados com resultados de sondagem geofísica, as quais permitem definir a variação lateral e vertical das litofacies, e o conhecimento da morfologia e limites da formação no topo e na base do aqüifero.

\subsection{0.- Interpretação de imagem satélite Landsat Thematic Mapper}

Os diferentes mapas geológicos existentes da zona de fronteira do Peru, Bolívia e Chile, apresentam uma grande complexidade de informação e falta de uma interrelação das unidades litoestratigráficas, dificultando estabelecer a correlação de dados desta zona. Por esta razão, como ferramenta importante de pesquisa, foi necessário o uso de imagem de satélite LANDSAT (TM), do ano 1995, banda $7,4,2$, da região limitrofe: coordenadas UTM: 8036.000 a 8080.000 Norte e 388.000 e 470.000 Este, escala 1:100.000.

O registro de informação facilitou a correlação das diferentes unidades litoestratigráficas que afloram na região limitrofe, e a identificação de estruturas como lineamentos, deformações, mapeamento de corpos de água e mapeamento de áreas deterioradas por explotação descontrolada dos recursos hídricos. Toda esta informação interpretada foi verificada e comprovada no campo e, como resultado, permitiu gerar mapas com informação integrada mais consistente e representativa da área de pesquisa.

O uso de imagem de satélite tem uma ampla aplicação na descrição qualitativa e quantitativa de bacias e redes de drenagem. Alguns autores como MORAIS, (1998) têm demostrado que o registro de dados de Sensoreamento Remoto são incorporados ao estudo de recursos hídricos de três formas: a) análise qualitativa de imagens e fotografias aéreas, que permite a identificação de alterações locais na cor e no volume de água dos rios, reservatórios etc.; b) mapeamento de superfícies líquidas, identificação de sistemas de falhas, fraturas etc.; c) análise 
qualitativa, que permite o estabelecimento de modelos que relacionam medidas pontuais a propriedades espectrais da água.

\subsection{0.- Avaliação hidrodinâmica}

Considerando como premissa que os sistemas aqüíferos são meios heterogêneos complexos, composto por diferentes tipos de materiais, em conseqüência suas propriedades hidrodinâmicas variam no espaço tridimensional, conjuntamente com a capacidade de armazenamento como comportamento dos fluxos em diferentes direções.

Essas propriedades podem ser quantificadas através de testes hidrodinâmicos e representadas como indices ou parâmetros hidrogeológicos. Neste caso o teste hidrodinâmico, além de permitir conhecer os parâmetros físicos do meio tais como condutividade hidráulica, transmissividade e coeficiente de armazenamento ou porosidade efetiva, constitui método adequado na avaliação dos limites de contorno como fronteiras impermeáveis, zona de recarga, relações com águas superficiais e relações entre aqüifferos.

Tendo em vista as considerações acima descritas, realizou-se testes hidrodinâmicos no poço profundo PA-6 com piezômetro no poço de observação PCA-6 localizado na zona do Ayro- Peru (área 1). O segundo teste realizou-se no poço PCH-ALT na zona de Charaña (área 2). Outros poços profundos não reúnem condições que permitam encontrar parâmetros representativos dos aqüíferos Capillune e Maure, por razões que o desenho construtivo dos poços de produção apresentam uma zona de filtros que abrange toda a espessura do perfil estratigráfico do poço envolvendo camadas permeáveis e impermeáveis. Este critério construtivo tem gerado uma interconexão hidráulica vertical do aqüífero Maure e Capillune, e tem efeito no fluxo das duas formações, no comportamento do rebaixamento, condição não recomendável para a estimativa dos parâmetros.

Os resultados de testes de bombeamento apresentados no capítulo 7, permitiram conhecer as características hidrodinâmicas do aqüífero Maure e Capillune, assim como as expectativas do comportamento do aqüífero no futuro, em projetos de captação de um volume maior com perspectiva econômica. 


\subsection{0.- Estimativa do balanço hidrológico.}

A estimativa do balanço obedece ao principio da conservação de massa ou principio da continuidade segundo a qual, em um sistema qualquer, a diferença entre as entradas e saídas é igual à variação do armazenamento dentro do sistema (FILHO, In FEITOSA, 1997). Em geral, para uma região, a equação básica do balanço hídrico pode ser escrita, considerando precipitação $(P)$, evapotranspiração real (ETR), deflúvio(R), e infiltração (l) como:

$P-E T R-R-I=\Delta S: \quad$ onde $(\Delta S)=$ variação no armazenamento

Com esta finalidade foram consolidados os seguintes dados:

a).- distribuição espacial e temporal de precipitações, obtidas das estações hidrometeorológicas do Servicio Nacional de Meteorologia e Hidrologia SENAMHI da Bolívia e do Peru: período 1960 a 1998;

b).- distribuição espacial e temporal do escoamento superficial do rio Uchusuma da estações limnimétricas do Ayro -Peru;

c).- distribuição temporal e espacial da evapotranspiração potencial estimada através das formulas usuais de PEMNAM, THORNWAIT, LERNER et al in CUSTODIO \& LLAMAS (1996). Estas fórmulas diferenciam-se por utilizar diferentes variáveis climáticas como: dados de insolação, radiação solar, temperatura, vento, umidade e balanço de radiação global.

A análise, quantificação e discussão global do balanço é apresentada no Capitulo sobre climatologia.

\subsection{0.- Avaliação da qualidade química das águas}

A qualidade da água subterrânea é tão importante quanto a sua quantidade. A disponibilidade dos recursos hídricos para determinados usos depende, fundamentalmente, da qualidade físico química, biológica e radiológica.(COSTA, In FEITOSA E FILHO, 1997).

A qualidade da água é definida por sua composição e pelo conhecimento dos efeitos que podem causar seus constituintes. O conjunto de todos os elementos 
que a compõe, permite estabelecer padrões de qualidade da água, classificandoas de acordo com seus limites permissíveis estudados e seus usos para o consumo humano, agricola e industrial.

Os processos e fatores que influem na evolução da qualidade das águas subterrâneas podem ser intrínsecos e extrínsecos ao aqüifero. A água subterrânea tende a aumentar em concentrações de substâncias dissolvidas a medida que percola através das diferentes formações geológicas.

Com base nesta premissa foi feita uma avaliação hidroquímica tendo por objetivo identificar e quantificar as principais propriedades físicas e constituintes químicos das águas subterrâneas, procurando estabelecer uma relação com o meio geológico.

Com esta finalidade realizou-se amostragem nas principais fontes de água cadastradas no âmbito do estudo. No local fizeram-se medições de alguns parâmetros como condutividade, $\mathrm{pH}$, temperatura. Os resultados são analisados e apresentados no capítulo 8. 


\section{CAPITULO III}

\section{CLIMATOLOGIA E BALANÇO HÍDRICO.}

\subsection{0.- Amplitude do período analisado}

Com o intuito de entender o comportamento do sistema hídrico, águas superficiais e subterrâneas em função de aportes e perdas no ciclo hidrológico, a área de interesse foi avaliada dentro do esquema geral dos parâmetros que definem o balanço hídrico coerente com o tipo de clima.

A região do estudo encontra-se na faixa de influência da zona de Convergência Intertropical Semipermanente (ZCIT) e Frente Polar do Pacifico. Esta interface é controlada pela circulação destas duas frentes que determinam a variação temporal e espacial dos parâmetros climáticos nesta região (PELT, 1993).

Os componentes que determinam a climatologia da Sub-bacia Uchusuma e sua influência na recarga de aqüiferos foram avaliados a partir da análise de uma serie histórica de dados meteorológicos do periodo 1960 a 1998, do "Servicio Nacional de Metorologia e Hidrologia" SENAMHI-Peru e "Servicio Nacional de Meteorología e Hidrologia" SENAMHI-Bolívia. A amplitude utilizada permite ter maior consistência e homogeneidade na interpretação das diferentes variáveis consideradas.

\subsection{0.- Rede de estações meteorológicas}

A climatologia foi caracterizada a partir de dados de cinco estações meteorológicas próximas à área de estudo que possuem informações de períodos longos e completos: Charaña, Abaroa da Bolivia; Paucarani, Chuapalca e Challapalca do Peru,. (TABELA 4 ) (FIGURA 2 p: 23).

TABELA 4 - LOCALIZAÇÃO DAS ESTAÇÕES METEOROLÓGICAS.

\begin{tabular}{|c|c|c|c|c|c|c|c|}
\hline \multirow{2}{*}{ Estação } & \multicolumn{3}{|c|}{ Localização Geográfica } & \multirow{2}{*}{$\begin{array}{l}\text { Categ } \\
\text { oria }\end{array}$} & \multirow[b]{2}{*}{ Variáveis } & \multirow{2}{*}{$\begin{array}{c}\text { Pais - } \\
\text { Departamento }\end{array}$} & \multirow{2}{*}{$\begin{array}{l}\text { Provincia - } \\
\text { Distrito }\end{array}$} \\
\hline & Long. & Lat. & Altitude $(\mathrm{m})$ & & & & \\
\hline Charaña & $69^{\circ} 26^{\prime}$ & $17^{\circ} 35^{\prime}$ & 4054 & $\mathrm{CO}$ & $P, T, H R, V$ & Bolivia- La Paz & Pacajes - Charaña \\
\hline Abaroa & $69^{\circ} 115$ & $17^{\circ} 32^{\prime}$ & 3953 & PLU & $P$ & Botivia-La Paz & Pacajes - Charaña. \\
\hline Paucarani & $69^{\circ} 47^{\prime}$ & $17^{\circ} 31^{\prime}$ & 4600 & PLU & $P$ & Peru- Tacna & Tacna - Palca \\
\hline Chuapalca & $17^{\circ} 21^{\prime}$ & $69^{\circ} 39^{\prime}$ & 4250 & PLU & $\mathrm{P}$ & Peru-Tacna & Tarata - Tarata \\
\hline Challapalca & $17^{\circ} 14^{\circ}$ & $69^{\circ} 48^{\prime}$ & 4200 & PLU & $p$ & Peru - Puno & Chucuito - Pizacoma \\
\hline $\begin{array}{l}\text { PLU: Pluviometria } \\
\text { CO : Climatologia }\end{array}$ & Ordinária & & $\begin{array}{l}\text { P: Precipita } \\
T: \text { Tempere } \\
\text { E: Evapora }\end{array}$ & $\begin{array}{l}\text { o } \\
\text { ra Tanque }\end{array}$ & & $\begin{array}{l}\text { HR: Umidade } \\
V: \text { Vento }\end{array}$ & elativa \\
\hline
\end{tabular}




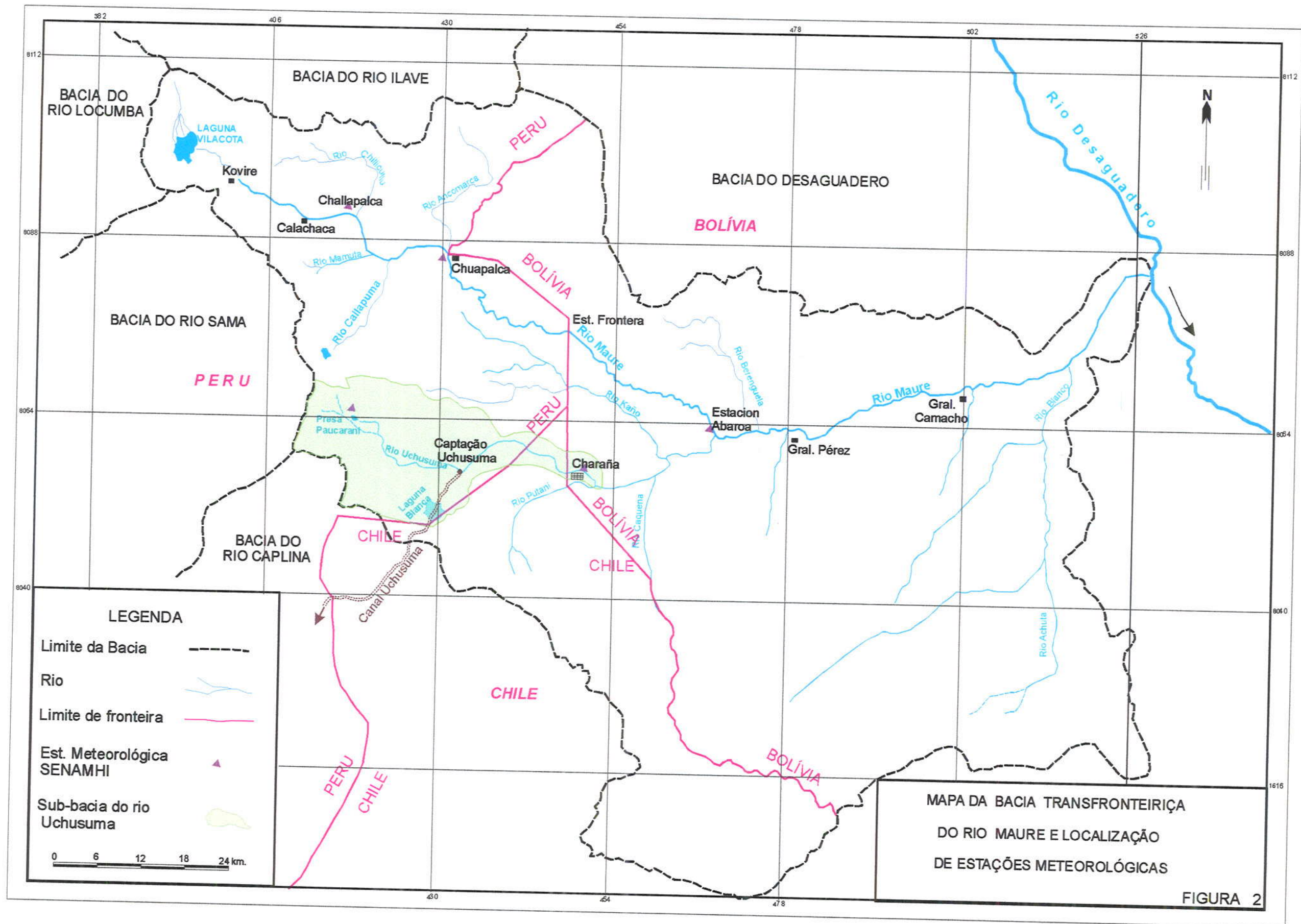




\subsection{0.- Parâmetros climáticos considerados}

Foram levantados dados médios mensais e anuais das principais variáveis climáticas para a análise correspondente (TABELA 5).

TABELA 5 - SUMÁRIO DE PARÂMETROS CLIMÁTICOS LOCAIS Estação Meteorológica Charaña Periodo 1960 -1998

\begin{tabular}{|c|c|c|c|c|c|c|c|c|c|}
\hline \multirow{2}{*}{ Mês } & \multirow{2}{*}{$\begin{array}{l}\text { Precipit. } \\
\text { (mm) }\end{array}$} & \multirow{2}{*}{$\%$} & \multicolumn{3}{|c|}{ Temperatura ${ }^{\circ} \mathrm{C}$} & \multirow{2}{*}{$\begin{array}{l}\text { Oscilação } \\
\text { Térmica }\end{array}$} & \multirow{2}{*}{$\begin{array}{c}\text { Umidade } \\
\text { Relativa } \\
\%\end{array}$} & \multirow{2}{*}{$\begin{array}{c}\text { Pressão } \\
\text { Atm. } \\
\text { Mb }\end{array}$} & \multirow{2}{*}{$\begin{array}{l}\text { Evapora. Tanque "A } \\
\text { (mm) }\end{array}$} \\
\hline & & & Máx & Min. & Med. & & & & \\
\hline Jan. & 102,46 & 31 & 18,2 & $-0,4$ & 10,5 & 18,6 & 57,2 & 626 & 138,1 \\
\hline Fev. & 76,38 & 22 & 17,9 & $-0,3$ & 10,4 & 18,2 & 56,8 & 626 & 107,7 \\
\hline Mar. & 55,28 & 16 & 18,1 & $-1,1$ & 9,9 & 19,2 & 54,7 & 626 & 113,0 \\
\hline Abr. & 12,21 & 4 & 18,1 & $-14,8$ & 9,3 & 22,9 & 43,0 & 626 & 131,0 \\
\hline Mai. & 2,38 & 1 & 16,7 & $-8,8$ & 7,1 & 25,5 & 36,9 & 627 & 133,2 \\
\hline Jun. & 1,54 & 0,5 & 14,8 & $-11,5$ & 5,0 & 26,3 & 35,9 & 627 & 113,7 \\
\hline Jul. & 0,51 & 0,5 & 15,0 & $-12,1$ & 4,9 & 27,1 & 33,0 & 267 & $\{13,3$ \\
\hline Ago. & 5,71 & 2 & 15,9 & $-10,6$ & 6,2 & 26,5 & 33,7 & 267 & 124,4 \\
\hline Set. & 2,53 & 1 & 16,9 & $-7,9$ & 7,9 & 24,8 & 34,6 & 262 & 140,0 \\
\hline Out. & 9,95 & 3 & 18,8 & $-5,9$ & 9,9 & 24,7 & 34,2 & 626 & 163,6 \\
\hline Nov. & 24,06 & 7 & 19,9 & $-3,9$ & 11,2 & 23,8 & 36,1 & 626 & 167,7 \\
\hline Dez. & 38,44 & 12 & 19,6 & $-1,9$ & 11,5 & 21,5 & 44,8 & 625 & 135,8 \\
\hline TOTAL & 331,44 & & 17,5 & $-5,8$ & 8,6 & 23,3 & 41,7 & & 1583,3 \\
\hline Média & & & & 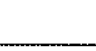 & 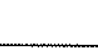 & & & & 131,9 \\
\hline
\end{tabular}

\subsection{1.- Precipitação}

O regime anual das chuvas na abrangência da sub-bacia é variável. Segundo a classificação climática de Thornthwaite e características próprias do altiplano, classificou-se como tipo climático $D(d) C^{\prime}$ por apresentar uma precipitação média de $331 \mathrm{~mm} / \mathrm{ano}$, condição semi-árido e frio (temperatura média $8,6^{\circ} \mathrm{C}$ ), e períodos extremamente secos durante a primavera, outono e inverno.

A distribuição espacial da precipitação no Altiplano está influenciada pela circulação regional de massas de ar e aspectos orográficos da Corditheira ocidental dos Andes. Dentro destas condicionantes, a presença de massas de nebulosidade e precipitação está ligada, fundamentalmente, ao período do verão associado a incremento de temperatura e deslocamento de massas de ar úmido da frente polar do Atlântico Sul que tem maior influência no altiplano (MIRANDA et.al, 2000). 
Durante o inverno se produz uma forte depressão térmica e baixas temperaturas de tipo glacial acima dos $4.000 \mathrm{~m}$., observando-se que, a partir do mês de abril, o clima torna-se dominantemente seco, e algumas precipitações isoladas durante o inverno são originadas pela penetração de massas polares marítimas que circulam no litoral Pacífico Sul.

O regime pluviométrico da área de pesquisa fol interpretado a partir de cinco estações meteorológicas localizadas no entorno da sub-bacia (TABELA 6), cujo comportamento no ciclo hidrológico anual é quase homogêneo nas diferentes áreas. A estação meteorológica de Charaña da Bolívia, e estação meteorológica de Paucarani do Peru mostram apropriadamente a pluviometria da área de pesquisa.

$\mathrm{Na}$ análise estatística de precipitações de 38 anos, observa-se que a distribuição temporal desta variável tem um comportamento irregular no ciclo hidrológico anual como no período analisado. As TABELAS 6, 7 e FIGURAS 3, 4 ( $p: 26,27$ ), ilustram este análises. No âmbito da sub-bacia e seu entorno, prevalece condições de aridez e longos períodos de intensa seca com precipitações menores que $300 \mathrm{~mm}$ ano, correspondendo a esta característica $36 \%$ do período analisado da estação Paucarani e $60 \%$ da estação Abaroa. Uma segunda característica está relacionada à ocorrência de anos de seca moderada ou de baixa umidade acompanhadas de precipitações entre 301 a $500 \mathrm{~mm}$, representando o $32 \%$ do período observado da estação Paucarani e $38 \%$ da estação Abaroa. No período de 38 anos, temos apenas três a quatro anos com precipitações maiores que $500 \mathrm{~mm}$ ano, (máxima precipitação registrada foi 690 $\mathrm{mm}$ no ano de 1984).

A precipitação média anual para trinta e nove anos é de $331,44 \mathrm{~mm}$, valor que é importante considerar na análise da recarga dos aqüíferos.

A ocorrência ou ausência de chuva no decurso do ano hidrológico e sua relação com a temperatura, dá uma característica especial as diferentes estações. A FIGURA 5 ( $p: 28$ ) ilustra, em parte, as condições climáticas que prevalecem nas diferentes épocas do ano: 
- Época seca, período compreendido entre abril e outubro, caracterizado por ausência de chuva; clima dominantemente seco e frio, a precipitação acumulada não supera os $35 \mathrm{~mm}$, e sua incidência anual é de $11 \%$.

- Época úmida de dezembro a março neste período a precipitação atinge um máximo de $273 \mathrm{~mm}$, equivalente a $82 \%$ da precipitação anual, e no mês de abril as chuvas diminuem apresentando características de época semi úmida.

TABELA 6 - DADOS DE PRECIPITAÇÃO MÉDIA DE CINCO ESTAÇÕES METEOROLÓGICAS (precipitação em mm)

\begin{tabular}{cccccc}
\hline Est/Met. & Paucarani & Charaña & Abaroa & Challapalca & Chuapalca \\
\hline Set. & 5,09 & 2,53 & 1,67 & 1,06 & 2,80 \\
Out. & 9,85 & 9,95 & 7,60 & 7,10 & 7,10 \\
Nov. & 23,05 & 24,06 & 22,90 & 25,20 & 24,80 \\
Dez. & 53,44 & 38,44 & 38,27 & 64,40 & 53,80 \\
Jan. & 106,63 & 102,46 & 95,69 & 98,80 & 108,80 \\
Fev. & 90,66 & 76,38 & 70,51 & 81,60 & 85,50 \\
Mar. & 67,93 & 55,28 & 49,30 & 67,70 & 64,70 \\
Abr. & 12,69 & 12,21 & 10,64 & 10,90 & 10,00 \\
Mai. & $, 3,79$ & 2,38 & 1,94 & 2,40 & 2,40 \\
Jun & 4,61 & 1,54 & 1,56 & 4,20 & 1,30 \\
Jul. & 2,58 & 0,51 & 0,23 & 0,30 & 0,10 \\
Ago. & 3,78 & 5,71 & 4,04 & 4,60 & 2,80 \\
\hline ANUAL & 384,11 & 331,44 & 304,36 & 360,80 & 355,40 \\
\hline FONTE: Dados trabalhados com registros de SENAMHI \\
Período de observação: $1960-1998$ Est. Paucarani, Charaña e Abaroa. \\
\hline \multicolumn{5}{c}{$1964-1997$ Est. Challapalca e Chuapalca. } \\
\hline
\end{tabular}

\section{FIGURA 3 - CURVA DE PRECIPITAÇÃO MÉDIA MENSAL DE CINCO ESTAÇÕES METEOROLOGICAS \\ Período 1960 - 1998}

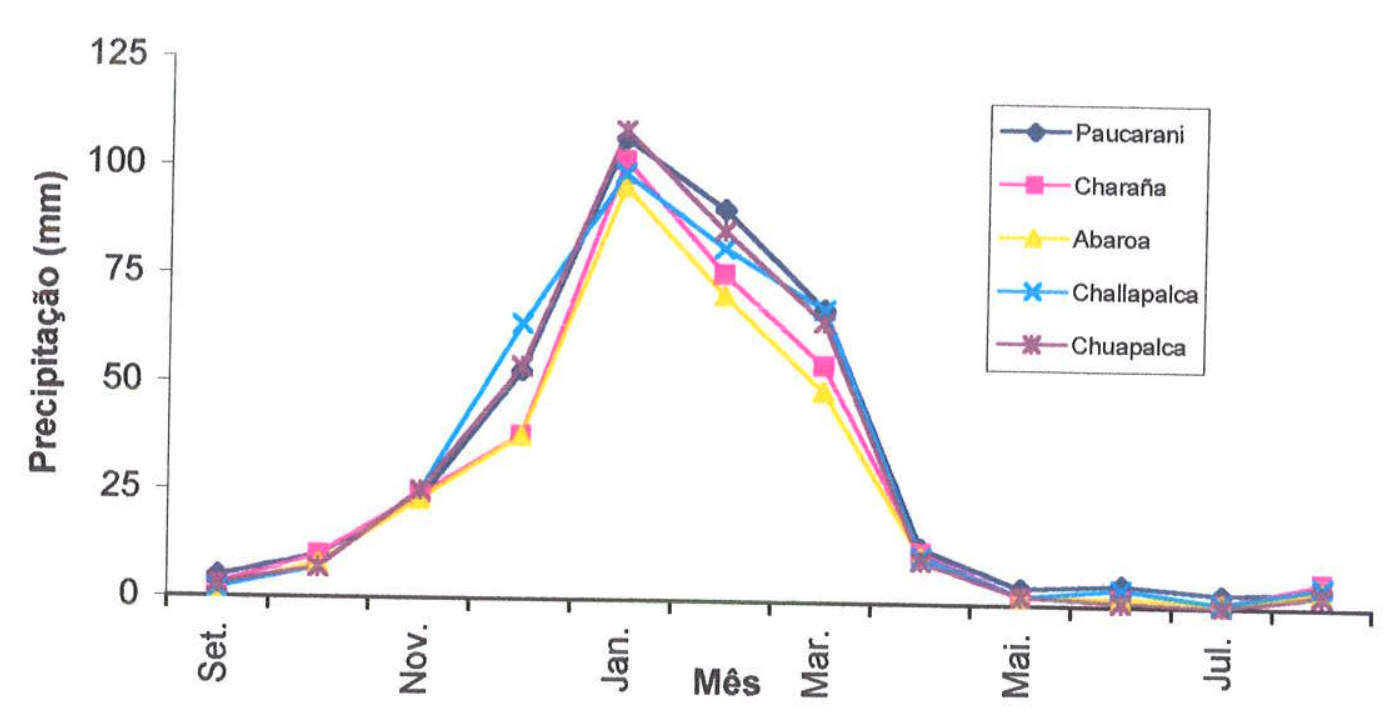

FONTE: Dados trabalhados com registros de SENAMHI 
TABELA 7 - CARACTERÍSTICAS PLUVIOMÉTRICAS NO ÂMBITO DA ÁREA DE ESTUDO Período analisado: 1960 - 1998

\begin{tabular}{|c|c|c|c|c|}
\hline \multirow{2}{*}{\multicolumn{2}{|c|}{ Características dos anos avaliados }} & \multicolumn{3}{|c|}{ Estação Meteorológica } \\
\hline & & Paucarani & Charaña & Abaroa \\
\hline $\begin{array}{l}\text { Precipitação menor do } \\
\text { que } 300 \mathrm{~mm}\end{array}$ & $\begin{array}{l}\mathrm{N}^{\circ} \text { de anos } \\
\% \text { de incidência }\end{array}$ & $\begin{array}{l}14 \\
36\end{array}$ & $\begin{array}{l}21 \\
54\end{array}$ & $\begin{array}{l}23 \\
60\end{array}$ \\
\hline $\begin{array}{l}\text { Precipitação entre } \\
301 \text { a } 500 \mathrm{~mm}\end{array}$ & $\begin{array}{c}N^{\circ} \text { de anos } \\
\% \text { de incidência }\end{array}$ & $\begin{array}{l}15 \\
38\end{array}$ & $\begin{array}{l}14 \\
36\end{array}$ & $\begin{array}{l}12 \\
32\end{array}$ \\
\hline $\begin{array}{l}\text { Precipitação maior ao } \\
\text { que } 500 \mathrm{~mm}\end{array}$ & $\begin{array}{l}\mathrm{N}^{\circ} \text { de anos } \\
\% \text { de incidência }\end{array}$ & $\begin{array}{l}10 \\
26 \\
\end{array}$ & $\begin{array}{c}4 \\
10\end{array}$ & $\begin{array}{l}3 \\
8\end{array}$ \\
\hline
\end{tabular}

FIGURA 4 - HISTOGRAMAS DE DADOS PLUVIOMÉTRICOS ANUAIS.

Período 1960 - 1998 Est. Met : Charaña, Abaroa, Paucarani

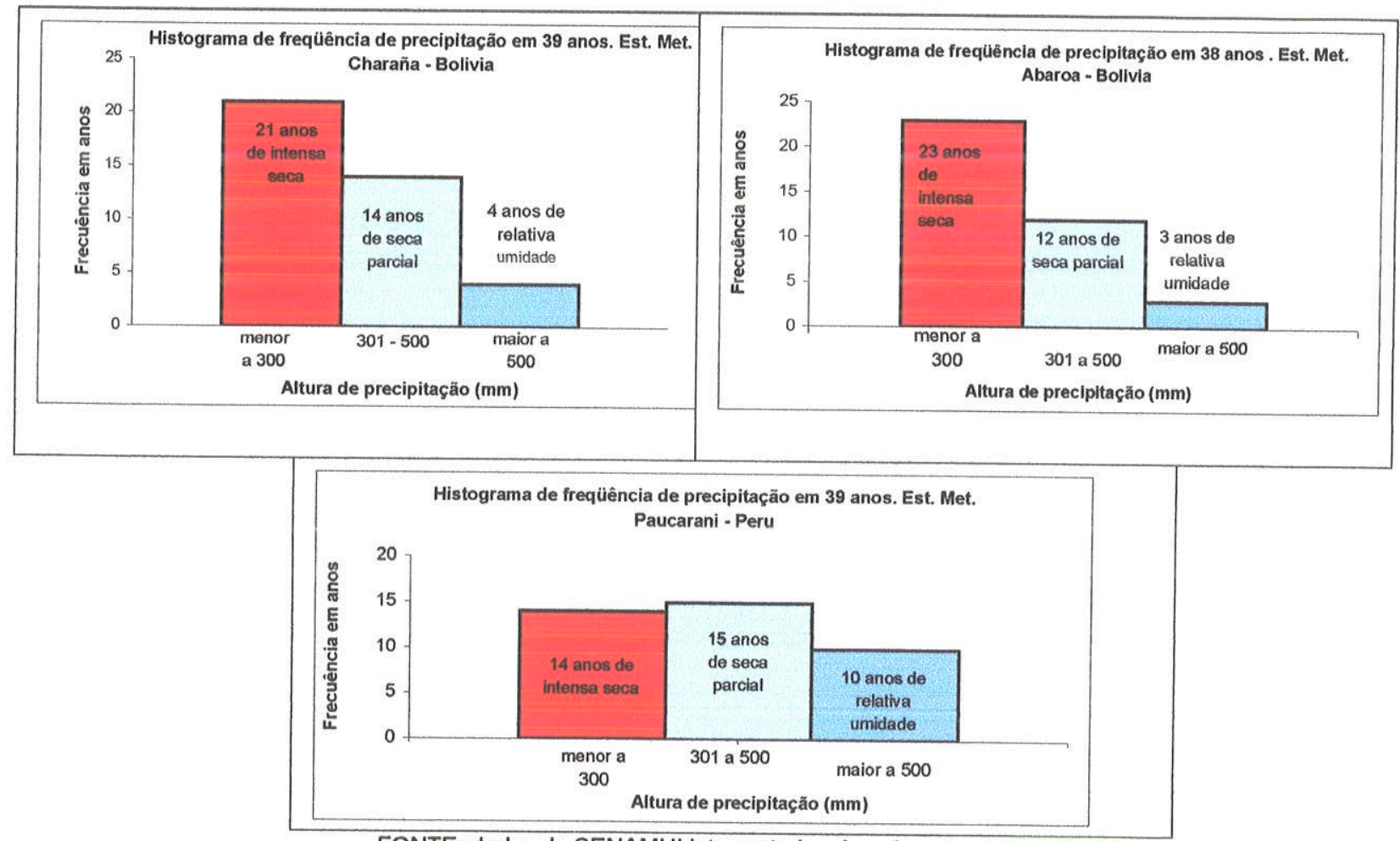

FONTE: dados de SENAMHI interpretados de pelo autor 
FIGURA 5 - CLIMATOGRAMA

Precipitação - Temperatura média

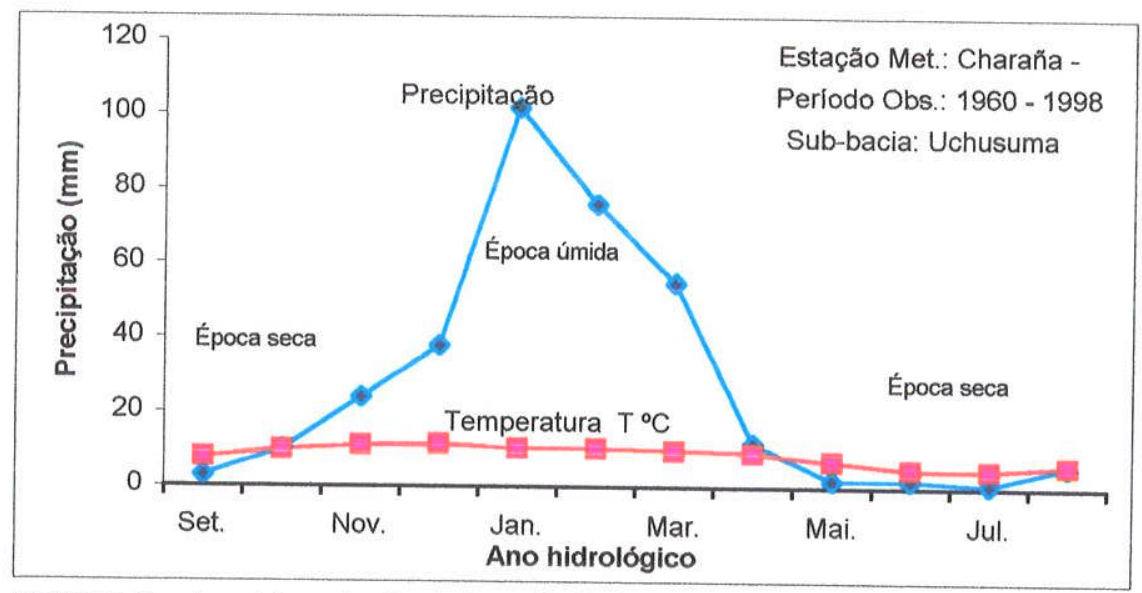

FONTE:: O autor - Interpretação de base de dados de SENAMHI PERU BOLIVIA

\section{3..2.- Temperatura}

Acima dos $4000 \mathrm{~m}$ de altitude a temperatura predominante é baixa do tipo frío. Dados da estação meteorológica de Charaña da Bolívia mostram o comportamento desta variável nas diferentes épocas do ano (TABELA 8)

A amplitude de variação entre a temperatura máxima e a mínima nas diferentes épocas do ano está ilustrada na FIGURA. 6 ( $p: 29$ ). Enquanto a variação da temperatura Máxima observa-se uma mínima flutuação durante o ano. Nos meses de maio a agosto as máximas atingem $16,7{ }^{\circ} \mathrm{C}$, e durante a primavera de setembro a novembro a temperatura aumenta, devido a baixa nebulosidade e maior insolação, até um máximo de $19,9^{\circ} \mathrm{C}$. Na época do verão, de dezembro a março, a temperatura diminui até $17,9^{\circ} \mathrm{C}$ pela presença de nebulosidade e precipitação.

A temperatura mínima flutua de modo mais notável segundo as estações; em épocas de inverno desce $\mathrm{a}-12,1^{\circ} \mathrm{C}$, no verão mantém-se com uma mínima de $0,04{ }^{\circ} \mathrm{C}$. A variação térmica ou mudanças bruscas a que está submetido a climatologia desta área esta apresentada na TABELA 9. 
TABELA 8 - REGISTRO DE TEMPERATURA MÉDIA MENSAL DA ESTAÇÃO METEOROLÓGICA DE CHARAÑA.

\begin{tabular}{cccc}
\multicolumn{2}{c}{ (Temperatura em ${ }^{\circ} \mathrm{C}$ do periodo } & \multicolumn{3}{c}{ Charaña } \\
\cline { 2 - 4 } Mês & Max. & Min. & Med \\
\cline { 2 - 4 } Set. & 16,9 & $-7,9$ & 7,9 \\
Out. & 18,8 & $-5,9$ & 9,9 \\
Nov. & 19,9 & $-3,9$ & 11,2 \\
Dez. & 19,6 & $-1,9$ & 11,5 \\
Jan. & 18,2 & $-0,4$ & 10,5 \\
Fev. & 17,9 & $-0,3$ & 10,4 \\
Mar. & 18,1 & $-1,1$ & 9,9 \\
Abr. & 18,1 & $-4,8$ & 9,3 \\
Mai. & 16,7 & $-8,8$ & 7,1 \\
Jun & 14,8 & $-11,5$ & 5,0 \\
Jul. & 15,0 & $-12,1$ & 4,9 \\
Ago. & 15,9 & $-10,6$ & 6,2 \\
\hline MEDIA & 17,5 & $-5,8$ & 8,6 \\
\hline
\end{tabular}

FONTE: SENAMHI Bolívia

TABELA 9 - VARIAÇÃO TÉRMICA MENSAL

\begin{tabular}{lllllllllllllll}
\hline & Set. & Out. & Nov. & Dez. & Jan. & Fev & Mar. & Abr. & Mai. & Jun. & Jul. & Ago. & ano \\
\hline Charaña & 24,8 & 24,7 & 23,8 & 21,5 & 18,6 & 18,2 & 19,2 & 22,9 & 25,5 & 26,3 & 27,1 & 26,5 & 23,3 \\
\hline FONTE: SENAMHI & -BOLIVIA
\end{tabular}

FIGURA 6 - VARIAÇÃO DA TEMPERATURA NAS DIFERENTES ÉPOCAS DO ANO.

Período 1960 - 1990. Est. Met. Charaña - Bolivia.

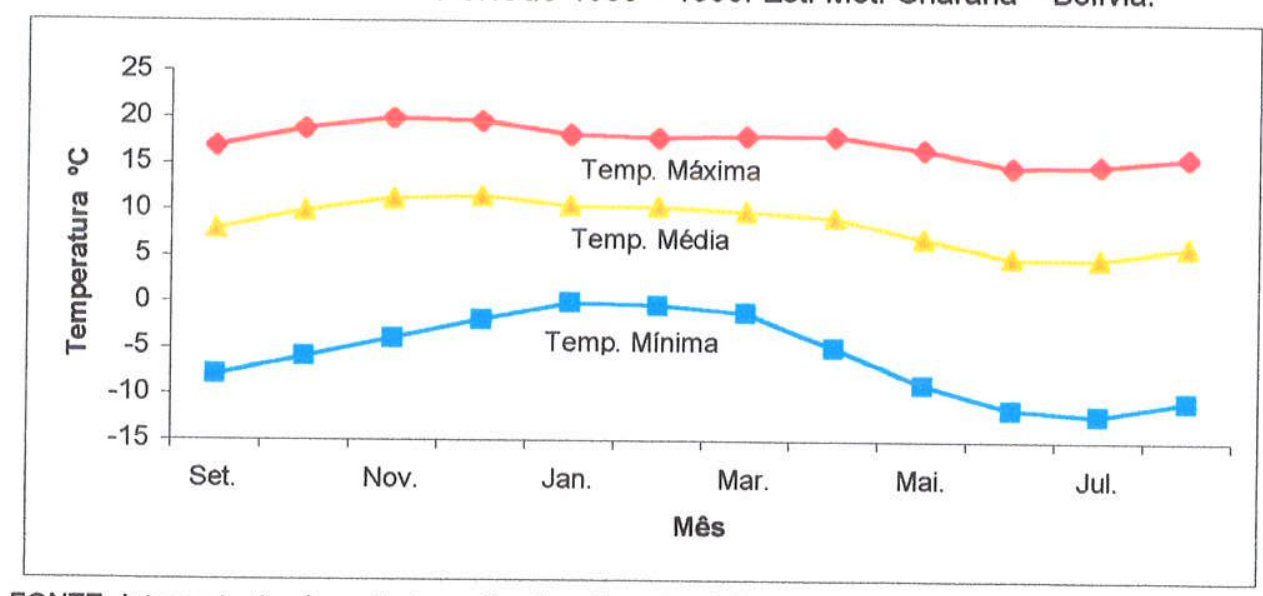

FONTE: Interpretação do período analisado pelo autor da base de dados de SENAMHI.

\subsection{3.- Umidade relativa}

No entorno dos nevados da Cordilheira Ocidental dos Andes, durante as estações de outono, inverno e primavera, apresenta-se um ambiente de seca ou de baixa umidade atmosférica, variando entre $33,0 \%$ a $36,9 \%$. No período de 
precipitações, dezembro a março, a porcentagem de umidade aumenta até um máximo de $57,2 \%$ (TABELA 10).

TABELA 10 - VARIAÇÃO DA UMIDADE RELATIVA NA SUB-BACIA UCHUSUMA.

\begin{tabular}{|c|c|c|c|c|c|c|c|c|c|c|c|c|c|}
\hline \multicolumn{14}{|c|}{ Umidade Relativa \% } \\
\hline $\begin{array}{l}\text { Est. } \\
\text { Met. }\end{array}$ & Set. & Out. & Nov. & Dez. & Jan. & Fev. & Mar. & Abr. & Mai. & Jun. & Jul. & Ago. & $\begin{array}{l}\text { Média } \\
\text { Anual }\end{array}$ \\
\hline Charaña & 34,6 & 34,2 & 36,1 & 44,8 & 57,2 & 56,8 & 54,7 & 43,0 & 36,9 & 35,9 & 33,0 & 33,7 & 41,7 \\
\hline
\end{tabular}

\subsection{4.- Vento}

Segundo os dados da estação meteorológica de Charaña observa-se que a orientação dominante dos ventos durante o dia seguem um rumo NE - SW, atingindo velocidades de 1,6 a $3,7 \mathrm{~m} / \mathrm{s}$, enquanto que, à noite, o movimento das massas de ar assume direção contrária.

A velocidade media anual estimada é de $3,6 \mathrm{~m} / \mathrm{s}$, e seu comportamento é uniforme em toda a área com pequenas variações no decurso do ano.

\subsection{5.- Cálculo de evapotranspiração}

A avaliação das perdas de água por fenômeno de evapotranspiração e sua implicação no balanço hídrico, tem sido estimada a partir de dados de evaporímetros da estação meteorológica de Charaña da Bolívia. O conhecimento desta variável, associado com o aporte de água das precipitações e outros componentes, permite estimar a variação no armazenamento dentro do sistema.

A evapotranspiração constitui um parâmetro importante no estudo da economia de água em reservatórios expostos à secagem natural, sendo um elemento de grande influência ecológica, animal e vegetal (TUBELIS \& LINO, 1987). Em conseqüência, a evapotranspiração têm uma aplicação importante no balanço hídrico em termos de "Evapotranspiração Potencial", conceito introduzido por Thornthwaite (CASTANY, 1967), (CUSTODIO, 1996), que significa "a máxima evapotranspiração possivel que pode ocorrer em condições favoráveis, quando o solo está bem provido de água, dentro de sua capacidade de campo e coberto por uma vegetação densa uniforme de pouca altura". Este parâmetro reflete a 
verdadeira necessidade de água para que as diferentes culturas possam desenvolver-se em condições ótimas de umidade. (LUQUE, 1981)

$\mathrm{Na}$ quantificação da evapotranspiração potencial foram utilizadas dois métodos de análise:

a).- O método de evaporimetro (TUCCI \& BELTRANE, 1993), permite calcular ETP a partir de registros de tanques de evaporação tipo " $A$ ", que representa efeitos integrados da radiação solar, vento, temperatura e umidade em função da evaporação de uma superfície de água livre, para o qual aplicou-se a seguinte expressão:

$$
E T P=q . E t
$$

Onde:

$$
\begin{aligned}
E T P & =\text { Evapotranspiração potencial diária }(\mathrm{mm} / \text { dia }) \\
q & =\text { Fator de correlação do tanque. } \\
E t & =\text { Evaporação medida no tanque tipo " } A \text { " }(\mathrm{mm} / \text { dia })
\end{aligned}
$$

O fator de correlação $(\boldsymbol{q})$ para o tanque classe "A" depende dos valores médios diários da umidade relativa do ar, velocidade do vento $\mathrm{em} \mathrm{km} / \mathrm{dia}$ e tipo de bordadura (TUBELIS \& LINO,1987). Na TABELA 11 são apresentados dados de evaporação registrados em tanque tipo " $A$ " e na TABELA 12 estão mostrados os resultados de ETP estimados segundo a

\begin{tabular}{|c|c|c|c|c|c|c|c|c|c|c|c|c|c|}
\hline Est./met. & Set. & Out. & Nov. & Dez. & Jan. & Fev. & Mar. & Abr. & Mai. & Jun. & Jul. & Ago. & Total \\
\hline $\begin{array}{l}\text { Pasto } \\
\text { Grande }\end{array}$ & 136,1 & 153,5 & 152,7 & 108,4 & 131,0 & 95,4 & 98,0 & 127,3 & 125.7 & 114,7 & 116,1 & 123,6 & 1482,5 \\
\hline Suches & 145,3 & 173,7 & 182,7 & 163,2 & 145,2 & 120,0 & 128,0 & 134,7 & 140,8 & 112,7 & 110,5 & 127,3 & 1684,1 \\
\hline Média & 140. & 163,6 & 167,7 & 135,8 & 138,1 & 107,7 & 113,0 & 131,0 & 133,2 & 113,7 & 113,3 & 125,4 & 1583,3 \\
\hline
\end{tabular}
fórmula (1).

TABELA 11 - DADOS DE EVAPORAÇÃO TANQUE TIPO "A"

(Tanque de evaporação tipo " $A$ " em $\mathrm{mm} / \mathrm{mês}$ )

\begin{tabular}{|c|c|c|c|c|c|c|c|c|c|c|c|c|}
\hline & Set. & Out. & Nov. & Dez. & Jan. & Fev. & Mar. & Abr. & Mai. & Jun. & Jul. & Ago. \\
\hline $\begin{array}{c}\text { Et. } \\
\text { Tanque.A }\end{array}$ & 140,0 & 163,6 & 167,7 & 135,8 & 138,1 & 107,7 & 113,0 & 131,0 & 133,2 & 113,7 & 113,3 & 125,4 \\
\hline$q$ & 0,7 & 0,7 & 0,7 & 0,7 & 0,7 & 0,7 & 0,7 & 0,7 & 0,7 & 0,7 & 0,7 & 0,7 \\
\hline $\begin{array}{c}\text { ETP } \\
\mathrm{mm} / \mathrm{mês}\end{array}$ & 98,0 & 114,5 & $\frac{117,4}{\mathrm{e}^{\text {"A" }}}$ & $\frac{95,1}{40 . \cdot 5}$ & 96,7 & 75,4 & 79,1 & 91,7 & 93,2 & 79,6 & 79,3 & 87,8 \\
\hline
\end{tabular}

TABELA 12 - ESTIMATIVA DE ETP A PARTIR DE DADOS DE EVAPORIMETRO TANQUE TIPO "A" 
b).- Método empirico de Thornthwaite (CASTANY, 1967), utiliza como variável fundamental a temperatura media mensal. O resultado parcial é ajustado por fator de correção de Camargo - Thornthwaite (TUBELIS \& LINO, 1987).

$$
\begin{aligned}
i=\left(\frac{t}{5}\right)^{1.514} \text { (2) } \quad i & =\text { indice de calor mensal. } \\
e=16\left(10 \frac{t}{I}\right)^{a} \text { (3) } \quad \mathrm{e} & =\text { Evapotranspiração potencial teórico } \mathrm{mm} / \mathrm{mês} . \\
t & =\text { temperatura média mensal }{ }^{\circ} \mathrm{C} \\
a & =675.10^{-9} l^{3}-771.10^{-7} \mathrm{I}^{2}+1972.10^{-5} \mathrm{I}+0.49239 \\
I & =\sum_{J a n}^{D e z} i
\end{aligned}
$$

\begin{tabular}{|c|c|c|c|c|c|c|c|c|c|c|c|c|c|}
\hline $\begin{array}{l}\text { Parâmetros } \\
\text { Estimados }\end{array}$ & Set. & Out. & Nov. & Dez. & Jan. & Fev. & Mar. & Abr. & Mai. & Jun. & Jul. & Ago. & Ano \\
\hline Temp. ${ }^{\circ} \mathrm{C}$ & 7,9 & 9,9 & 11,2 & 11,5 & 10,5 & 10,4 & 9,9 & 9,3 & 7,1 & 5,0 & 4,9 & 6,2 & 8,6 \\
\hline $\begin{array}{l}\text { Indice Calor } \\
\text { mensal "l" }\end{array}$ & 1,99 & 2,81 & 3,39 & 3,52 & 3,07 & 3,03 & 2,81 & 2,55 & 1,70 & 1,00 & 0,97 & 1,38 & 28,22 \\
\hline "e" teórico & 42,10 & 52,05 & 58,46 & 59,93 & 55,01 & 54,52 & 52,05 & 49,08 & 37,58 & 27,39 & 26,87 & 33,53 & \\
\hline $\begin{array}{c}\text { Coef. De ajuste } \\
\text { "k" }\end{array}$ & 1,00 & 1,07 & 1,07 & 1,12 & 1,12 & 0,98 & 1,05 & 0,98 & 0,97 & 0,93 & 0,96 & 1,00 & \\
\hline $\operatorname{ETP}(m m)=k \cdot e$ & 42,10 & 55,69 & 62,55 & 67,12 & 61,61 & 53,42 & 54,65 & 48,09 & 36,45 & 25,47 & 25,79 & 33,53 & 566,47 \\
\hline
\end{tabular}

$E T P=k . e \quad(4)$

$k=$ Coeficiente de ajuste de Camargo-Thornthwaite.

ETP $=$ Evapotranspiração potencial para o mês em $\mathrm{mm} / \mathrm{mês}$

\begin{tabular}{|c|c|c|c|c|c|c|c|c|c|c|c|c|c|}
\hline $\begin{array}{l}\text { Met. } \\
\text { Aplicados }\end{array}$ & Set. & Out. & Nov. & Dez. & Jan. & Fev. & Mar. & Abr. & Mai. & Jun. & Jul. & Ago. & Ano \\
\hline $\begin{array}{c}\text { Evapo. } \\
\text { Tanque "A" }(\mathrm{mm})\end{array}$ & 140,0 & 163,6 & 167,7 & 135,8 & 138,1 & 107,7 & 113,0 & 131,0 & 133,2 & 113,7 & 113,3 & 125,4 & \\
\hline $\begin{array}{l}\text { ErP função. } \\
\text { Tanq"A (mm") }\end{array}$ & 98,0 & 114,5 & 117,4 & 95,1 & 96,7 & 75,4 & 79,1 & 91,7 & 93,2 & 79,6 & 79,3 & 87,8 & \\
\hline $\begin{array}{c}\text { Thornthwaite } \\
(\mathrm{mm})\end{array}$ & 42,10 & 55,69 & 62,55 & 67,12 & 61,61 & 53,42 & 54,63 & 48,09 & 36,45 & 25,47 & 25,79 & 33,53 & \\
\hline
\end{tabular}

TABELA 13.- ESTIMATIVA DE ETP POR MÉTODO DE THORNTHWAITE

FONTE: Dados estimados pelo autor

TABELA 14.- .SUMÁRIO DE ETP CÁLCULADOS POR DIFERENTES MÉTODOS 


\section{3.-6.- Análise de dados de Evapotranspiração Potencial (ETP)}

Segundo os métodos aplicados, a amplitude de variação de ETP apresenta valores máximos nos meses de setembro a março e os valores mínimos nos meses de junho e julho correspondente á época seca.(FIGURA 7)

Na TABELA 14 está apresentado o sumario de ETP estimados por diversos métodos. Através da comparação dos resultados obtidos, trata-se de demostrar as desigualdades que podem induzir os diferentes métodos quando do tratamento de dados, porquanto cada método integra, dentro da fórmula, uma ou mais variáveis climáticas diferentes e seus modelos analíticos utilizam coeficientes de ajuste, em parte empíricos e em parte dependentes de fatores meteorológicos. A esta adiciona-se o fato de que as condições climáticas diferem daquelas onde a equação foi desenvolvida, e os resultados refletem essa desigualdade entre os diversos métodos. Porém o método de Thornthwaite é recomendado para seu uso na América do Sul pela UNESCO (1982).

FIGURA 7 - ETP ESTIMADA POR DIFERENTES MÉTODOS PARA SUB-BACIA UCHUSUMA

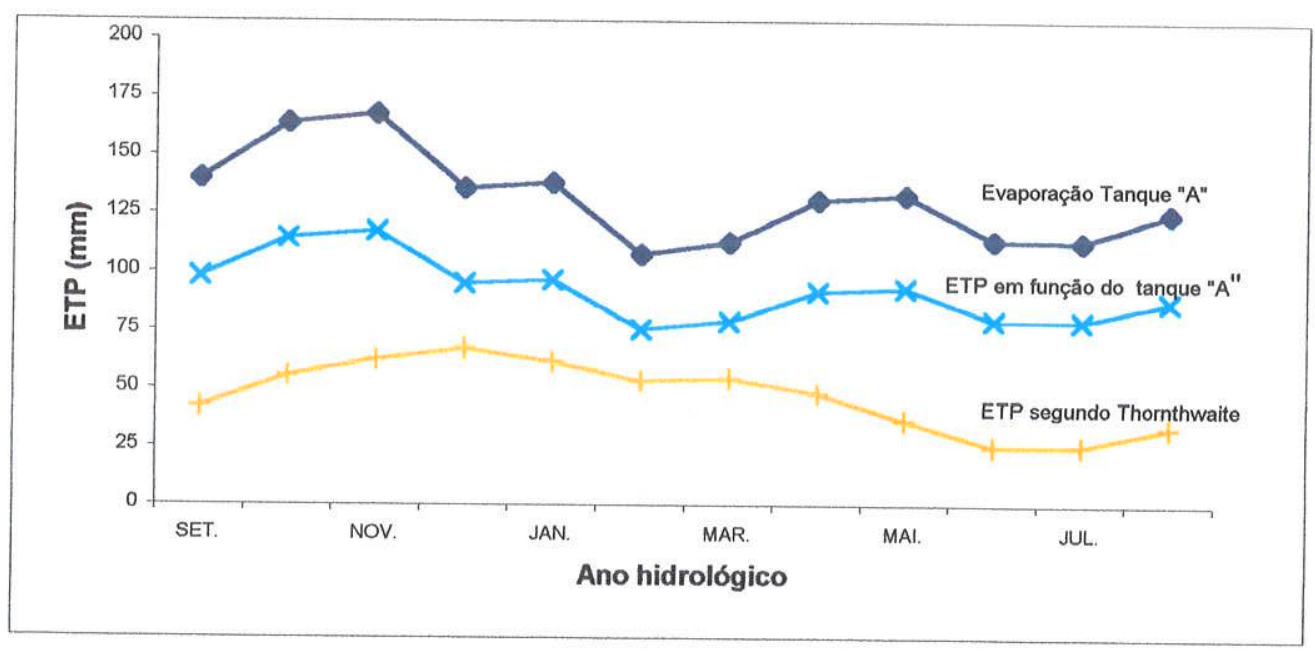

Na TABELA 15 apresenta-se os coeficientes de correlação entre os diferentes métodos de estimativa de ETP aplicados na bacia do lago Titicaca do Peru (APAZA 1997). Na tabela mostra-se a relação média de ETP entre o método de Penmam e Evaporação de tanque " $A$ " igual a 0,77; o índice trata de revelar que há maior evaporação de superfícies de água livre no Altiplano em relação evapotranspiração. A relação ETP entre o método do Tanque " $A$ " e método de 
Penmam é de 0,9 evidenciando que os dois métodos tem um comportamento quase similar. Porém a relação entre Thornthwaite - Penmam e Thornthwaite Tanque "A" apresenta coeficientes menores a 0,5. Este índice evidencia que estes métodos não são comparáveis, embora isto não signifique desestímulo de seus usos nos cálculos de ETP.

TABELA 15. COEFICIENTES DE CORRELAÇÃO DE ETP ENTRE DIVERSOS METODOS APLICADOS NA BACIA DO LAGO TITICACA DO PERU $(\mathrm{mm} / \mathrm{mês})$

C Set. Out. Nov. Dez. Jan. Fev. Mar. Abr. Maj. Jun. Jul. Ago. Media

\begin{tabular}{|c|c|c|c|c|c|c|c|c|c|c|c|c|c|}
\hline$P / A$ & 0,75 & 0,73 & 0,73 & 0,76 & 0,76 & 0,83 & 0,81 & 0,77 & 0,82 & 0,79 & 0,78 & 0,74 & 0,77 \\
\hline $\mathrm{Fa} / \mathrm{P}$ & 0,92 & 0,94 & 0,95 & 0,91 & 0,90 & 0,84 & 0,85 & 0,90 & 0,85 & 0,88 & 0,89 & 0,93 & 0,90 \\
\hline$T / P$ & 0,38 & 0,41 & 0,45 & 0,49 & 0,55 & 0,51 & 0,53 & 0,51 & 0,38 & 0,33 & 0,28 & 0,35 & 0,43 \\
\hline$T / f A$ & 0,41 & 0,43 & 0,47 & 0,54 & 0,60 & 0,61 & 0,62 & 0,57 & 0,45 & 0,37 & 0,32 & 0,37 & 0,48 \\
\hline $\begin{array}{l}\text { Méto } \\
\text { : Méto } \\
\text { ONTE: }\end{array}$ & $\begin{array}{l}\text { o de P } \\
\text { O de T } \\
\text { PAZA }\end{array}$ & $\begin{array}{l}\text { NMAN } \\
\text { ornthw } \\
\text { (1997) }\end{array}$ & & & $\begin{array}{l}\text { 1:Eva } \\
\text { : Eva }\end{array}$ & $\begin{array}{l}\text { oraçä } \\
\text { otrans }\end{array}$ & $\operatorname{tanqu}$ & A & & $f A$ : & TP em & funçãc & $\tan q$ \\
\hline
\end{tabular}

\subsection{0.- Balanço hídrico}

Para compreender a dinâmica de uma bacia em função dos componentes externos e internos, implica consolidar as possiveis variáveis em um modelo, que represente de um modo aproximado a imagem do sistema real. Neste entender, as entradas e saídas constituem variáveis hidrológicas mensuráveis, e sua estrutura é um conjunto de equações que integram variações do armazenamento, em função das entradas e saidas no sistema.

As entradas $E(t)$ e saidas $S(t)$ são expressas como funções de um periodo do tempo (t), que determinam a variação do armazenamento no sistema (dV/dt). Para uma região a equação básica do balanço hídrico pode ser escrita:

$$
E(t)-S(t)=d V / d t
$$


FIGURA 8 - ESQUEMA DO BALANÇO HIDRICO

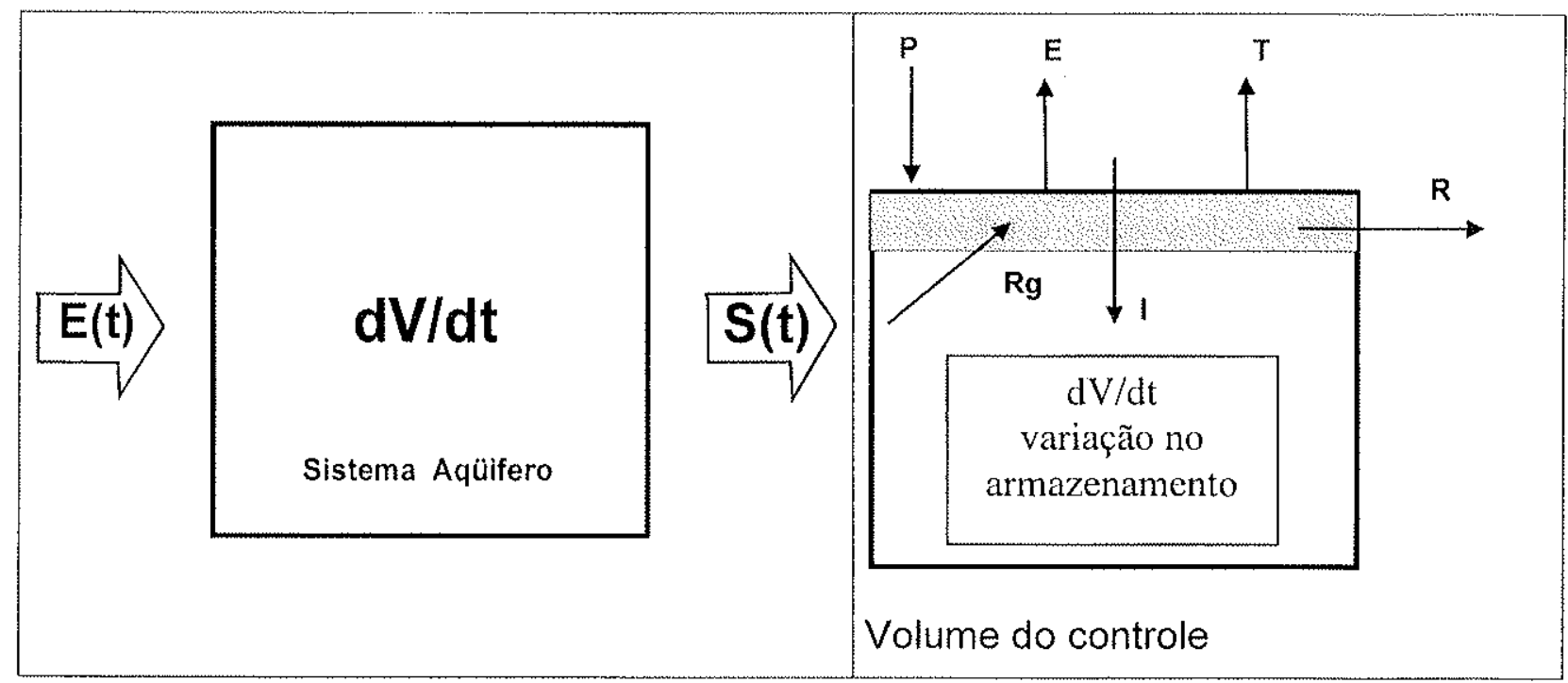

FONTE: Bear e Levin 1969

\section{Equação geral}

$P-R-R g-E-T-I=d V / d t \quad$ (6 ) onde:

P: precipitação em ( $\mathrm{mm})$

$\mathrm{R}$ : escoamento superficial

$\mathrm{Rg}$ : escoamento sub superficial

E: evaporação $(\mathrm{mm})$

T: transpiração $(\mathrm{mm})$.

I: infiltração $(\mathrm{mm})$

DV/dt: variação no armazenamento

Com esta finalidade foram consolidados os seguintes dados:

a).- Distribuição espacial e temporal de precipitações da estação meteorológica de Charaña da Bolívia.

b).- Distribuição espacial e temporal do escoamento superficial, obtidos das estações limnimétricas do rio Uchusuma.Ayro do Peru.

c).- Distribuição temporal e espacial da ETP evapotranspiração potencial estimada através das formulas usuais de THORNTHWAITE. 


\subsection{1.- Estimativa do balanço hídrico}

Para a estimativa do balanço hídrico da sub-bacia Uchusuma, utilizou-se o método de Thornthwaite (CASTANY, 1967) que está baseado em elementos de precipitação e evapotranspiração potencial ETP para uma capacidade de armazenamento de $100 \mathrm{~mm}$.

A TABELA 16 e FIGURA 9 apresentam o comportamento mensal do balanço hídrico; observa-se que durante o período de janeiro a março o aqüífero recebe recargas na sub bacia até um máximo de $64,46 \mathrm{~mm}$; nos meses seguintes, de abril a dezembro, caracteriza-se por ser um periodo de seca ou déficit de água, que impossibilita o desenvolvimento de qualquer tipo de cultura, as precipitações isoladas deste período são evapotranspiradas e não restituem as perdas.

O aqüífero Maure além de receber aportes nos limites da sub-bacia, recebe recargas na extensão regional. Segundo a estratigrafia regional, a bacia sedimentar da formação Maure estende-se desde o paralelo $14^{\circ}$ Lat Sul, e com maior amplitude dentro do limite dos $15^{\circ}$ a $18^{\circ}$ Lat Sul e $71^{\circ}$ a $69^{\circ}$ Long Leste. TABELA 16. BALANÇO HIDRICO DA SUBB-BACIA DO RIO UCHUSUMA - MÉTODO DE
THORNTHWAITE

(Capacidade de armazenamento do solo: $100 \mathrm{~mm}$ )

\begin{tabular}{|c|c|c|c|c|c|c|c|c|c|c|c|c|c|}
\hline & Set. & Out. & Nov. & Dez. & Jan. & Fev. & Mar. & Abr. & Mai. & Jun. & Jul. & Ago. & $\begin{array}{l}\text { Total } \\
\text { ano }\end{array}$ \\
\hline $\operatorname{ETP}(\mathrm{mm})$ & 42,10 & 55,69 & 62,55 & 67,12 & 61,61 & 53,42 & 54,63 & 48,09 & 36,45 & 25,47 & 25,79 & 33,53 & \\
\hline$P(m m)$ & 2,53 & 9,95 & 24,06 & 38,44 & 102,46 & 76,38 & 55,28 & 12,21 & 2,38 & 1,54 & 0,51 & 7,71 & 331,44 \\
\hline$P-\operatorname{ETP}(\mathrm{mm})$ & $-39,57$ & $-45,74$ & $-38,49$ & $-28,68$ & 40,85 & 22,96 & 0,65 & $-35,88$ & $-34,07$ & $-23,93$ & $-25,28$ & $-25,82$ & \\
\hline $\operatorname{Ar}(\mathrm{mm})$ & 0,00 & 0,00 & 0,00 & 0,00 & 40,85 & 63.81 & 64,46 & 28,58 & 0,00 & 0,00 & 0,00 & 0,00 & 64,46 \\
\hline $\operatorname{ETR}(\mathrm{mm})$ & 2,53 & 9,95 & 24,06 & 38,44 & 81,61 & 53,42 & 54,63 & 12,21 & 2,38 & 1,54 & 0,51 & 7,71 & \\
\hline $\begin{array}{l}\text { Excedente } \\
(\mathrm{mm})\end{array}$ & 0,00 & 0,00 & 0,00 & 0,00 & 0,00 & 0,00 & 0,00 & 0,00 & 0,00 & 0,00 & 0,00 & 0,00 & \\
\hline Déficit $(\mathrm{mm})$ & 39,57 & 45,74 & 38,49 & 28,68 & 0,00 & 0,00 & 0,00 & 0,00 & 5,49 & 23,93 & 25,28 & 25,82 & \\
\hline Esc. $(\mathrm{mm})$ & 0,00 & 0,00 & 0,00 & 0,00 & 0,00 & 0,00 & 0,00 & 0,00 & 0,00 & 0,00 & 0,00 & 0,00 & \\
\hline C. M.U & $-0,93$ & $-0,82$ &,- 061 &,- 042 & 0,66 & 0,42 & 0,01 & $-0,74$ & $-0,93$ & $-0,93$ & $-0,98$ & $-0,77$ & \\
\hline
\end{tabular}


FIGURA 9 - DIAGRAMA DO BALANÇO HÍDRICO - MÉTODO DE THORNTHWAITE

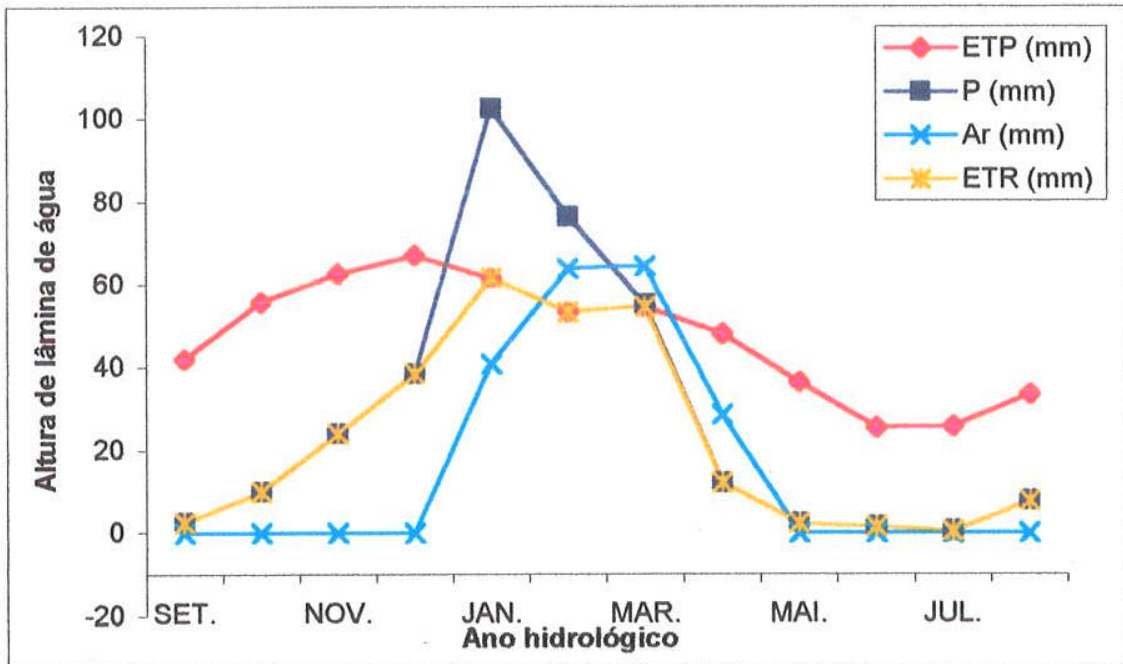

FONTE: Interpretação do período analisado pelo autor da base de dados de SENAMHI. 


\section{CAPITULO IV \\ GEOMORFOLOGIA E GEOLOGIA.}

\subsection{0.- Características geomorfológicas da regionais do altiplano}

Ao longo da Cordilheira Central dos Andes da América do Sul, diferentes feições morfoestruturais salientam e caracterizam as diferentes áreas geográficas desta região. Dentro desta, a área de estudo encontra-se circunscrita em uma unidade morfoestrutural denominada "O Altiplano". Esta unidade localiza-se na faixa central dos contrafortes da Cordilheiras Oriental e Ocidental dos Andes. Regionalmente estende-se em direção NW -SE ao longo de $2000 \mathrm{Km}$, por 200 Km de largura aproximada, a uma altitude entre 3.700 a 4.600 m (LAVENU, 1992 In DEJOUX y ILTIS) (FIGURA 10).

FIGURA 10 - MAPA MORFOESTRUTURAL DA REGIÃO DO ALTIPLANO

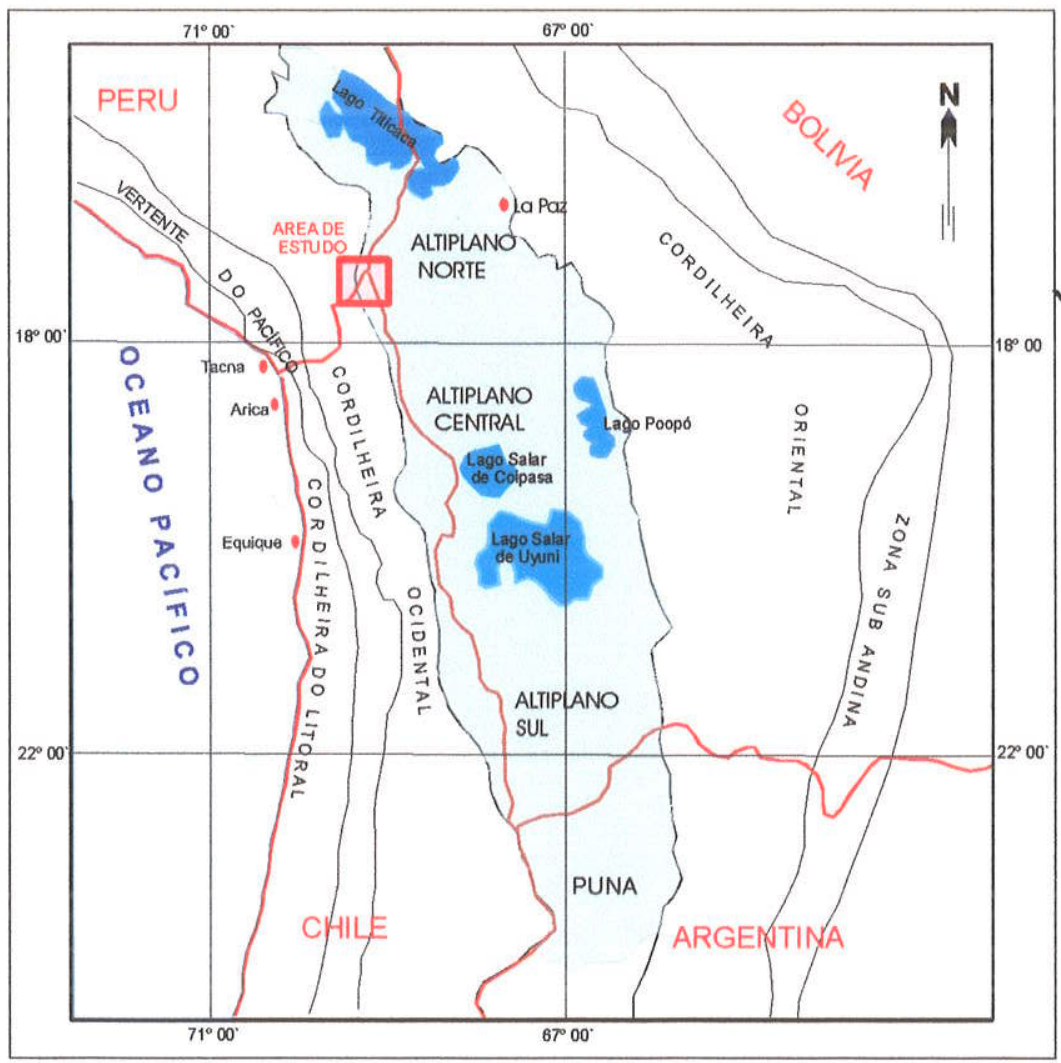

Fonte: Lavenu et al. (1984). 
O Altiplano abrange um amplo território dos paises do Peru, Bolívia, Chile e Argentina. A zona norte e centro do Altiplano, está öcupada por dois grandes lagos de regime permanente: o lago Titicaca e o lago Poopó. A zona sul é mais árida, abrangendo os domínios de uma grande área de terra de salmoura conhecidas como "Salares" de Coipasa e Uyuni (antigos lagos extintos).

As diferentes unidades morfológicas guardam um alinhamento estrutural NW SE, que reflete o aspecto linear das estruturas tectônicas do sistema da Cordilheira dos Andes. Regionalmente o relevo do Altiplano caracteriza-se por seu desenvolvimento sobre formações mesozóicas e cenozóicas, exibindo uma ampla superfície plana atravessada por cadeias de montanhas secundarias deformadas pela tectônica do levantamento Andino. Estas áreas têm sido modeladas seguindo a evolução estrutural dominante da região, adotando características peculiares nas diversas localidades até configurar a expressão topográfica e morfológica atual.

No altiplano tem sido diferenciados cinco grandes grupos de expressão geomorfológica: planícies e depressões $33,5 \%$, depósitos de vertente $5,3 \%$, colinas e mesetas vulcânicas $19,5 \%$, montanhas $33,3 \%$, superfícies de água 8,4 $\%$ (ALT, 1995)

\subsection{0.- Características geomorfológicas da bacia do rio Uchusuma.}

O cenário onde se localiza a área do estudo "sub-bacia do rio Uchusuma" situa-se na vertente oriental da Cordilheira Ocidental dos Andes, na cota de 4050 a 5700 metros de altitude. Localmente apresenta afloramentos da seqüência vulcanosedimentar do Terciario superior ao Quaternário.

Na FIGURA 11 (p: 40) mostra-se o panorama geomorfológico local da sub-bacia, destacando-se como limites da bacia um conjunto de elevações da cadeia de vulcões denominada "Cordilheira el Barroso", com elevações entre 4860 m a 5730 m tais como: nevado Paucarani 5623 m (lado Norte), montanha Queñuta de 5116 m (lado Sul), nevado Monja, Huencune no lado Oeste, colina Pacocahua del Uchusuma no Leste. No território boliviano destacamse o nevado Cerke de 4569 $m$. Em contraste com estas elevações, no sopé dos nevados apresenta-se uma superficie plana de forma triangular com suave inclinação em direção leste, 
projetando-se no território chileno e boliviano como parte do leque aluvial desenvolvido pela evolução do rio Uchusuma durante o Pleistoceno e Quaternário.

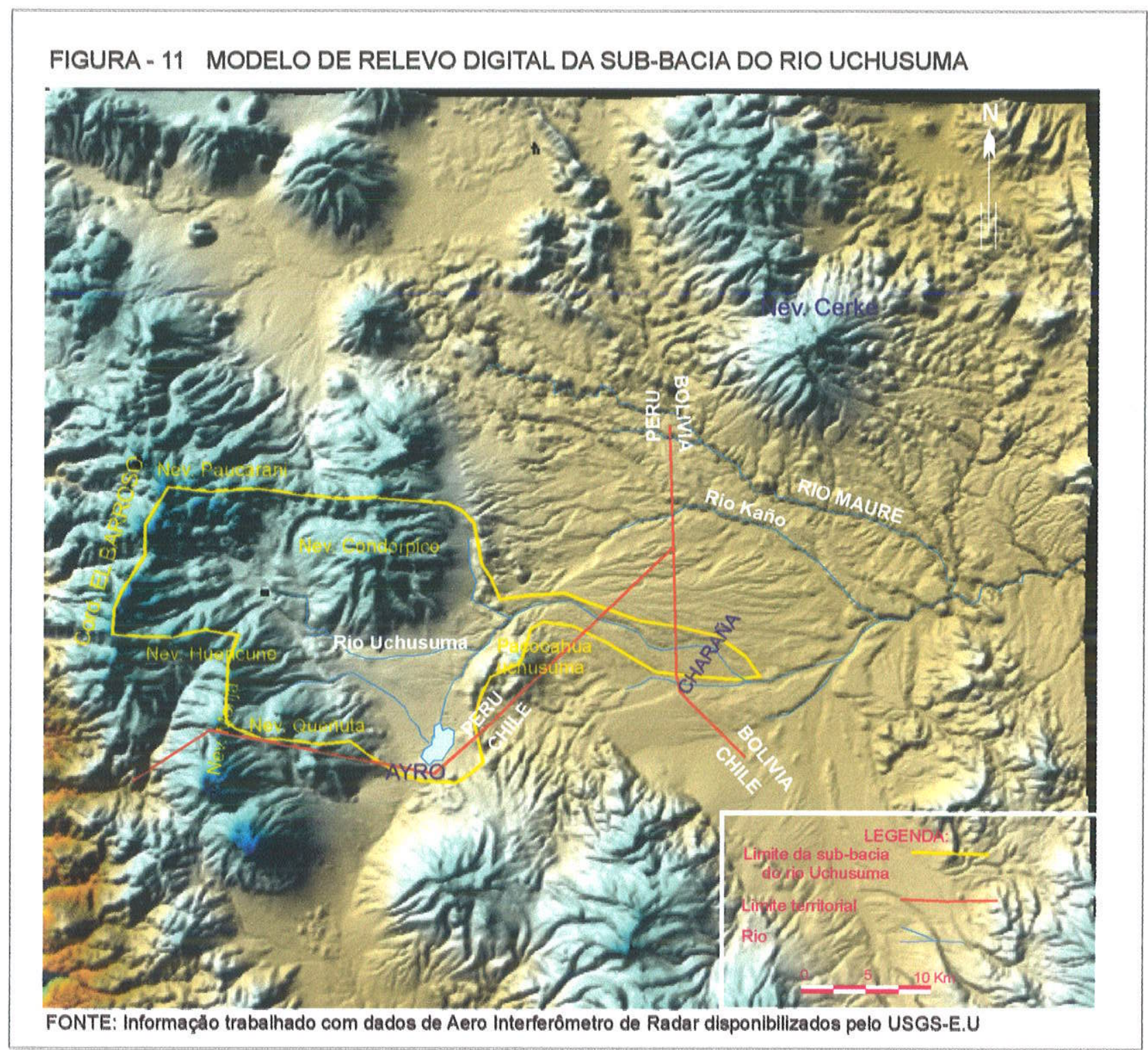

O sistema de drenagem desenvolvido sobre diferentes litotipos que afloram na sub-bacia, tem sido determinante no modelamento geomorfológico local, cujo desenho hídrico, de modo geral, apresenta uma configuração dendrítica com vales muito restritos. 
A rede hidrográfica local nasce no território peruano (FIGURA 12, p: 42), nas altas montanhas do "Sistema de Cordilheira el Barroso" (cota $5453 \mathrm{~m}$ a $5742 \mathrm{~m}$ ). Os numerosos e pequenos riachos confluem para formar o rio Uchusuma, próximo ao local e barragem Paucarani. A jusante recebe importantes aportes das boçorocas naturais: Uncalluta, Ancochaullane, Vilapucara, e Ancuyo. O rio Uchusuma, na zona de Ayro, desloca-se de oeste em direção leste controlado por estruturas locais. Próximo à fronteira com o Chile, no local Rosas Pata, o vale apresenta um estrangulamento e muda para direção sudeste atravessando uma pequena área do território Chileno, e logo ingressa no território boliviano, para juntar-se ao rio Putani. Continuando sua trajetória, desemboca no rio Casapilla e este no rio Maure para finalmente desembocar no rio Desaguadero.

Na imagem de satélite LANDSAT 742 (FIGURA 14, p:53) salienta-se com nitidez a evolução do rio Uchusuma no sentido de acumulação de materiais sobre as planícies do território chileno e boliviano. Observa-se a geometria de um leque aluvial com eixo de deslocamento em direção NE. Os materiais provenientes da zona do Ayro - Peru, foram acumulados sobre Ignimbritos da Formação Sencca ou Pérez. A amplitude de acumulação dos materiais evidencia a dinâmica das transformações do rio Uchusuma que foram ocorrendo nos diferentes periodos.

\subsection{0.- Evolução geomorfológica}

Muitos pesquisadores tentaram explicar a evolução do Altiplano dentro da Cordilheira dos Andes peruano-boliviano a partir de modelos tectônicos baseados na sucessão de fases de distensão e separados por fases de compressão (MARTÍNEZ, 1980; LAVENU, 1981). Segundo estes pesquisadores, o Altiplano durante o Terciario, desenvolveu-se em uma área de depressão tectônica interandina (graben), formando uma ampla bacia em expansão preenchidas por materiais sedimentares e vulcano-sedimentares, estruturalmente controlada por blocos deslocados longitudinal e transversalmente, e afetados por uma complexa evolução de reajustes no comportamento morfológico regional. Esta característica teria definido o sistema de drenagem fechado (endorreica) com extensos lagos como Titicaca e Poopó. Alguns lagos, ao longo da história, teriam alcançado um nivel de maturação avançada como salares: Salar de Uyuni e Coipasa no Sul. Por outro lado, em oposição às teorias anteriores, vários trabalhos recentes tentam 


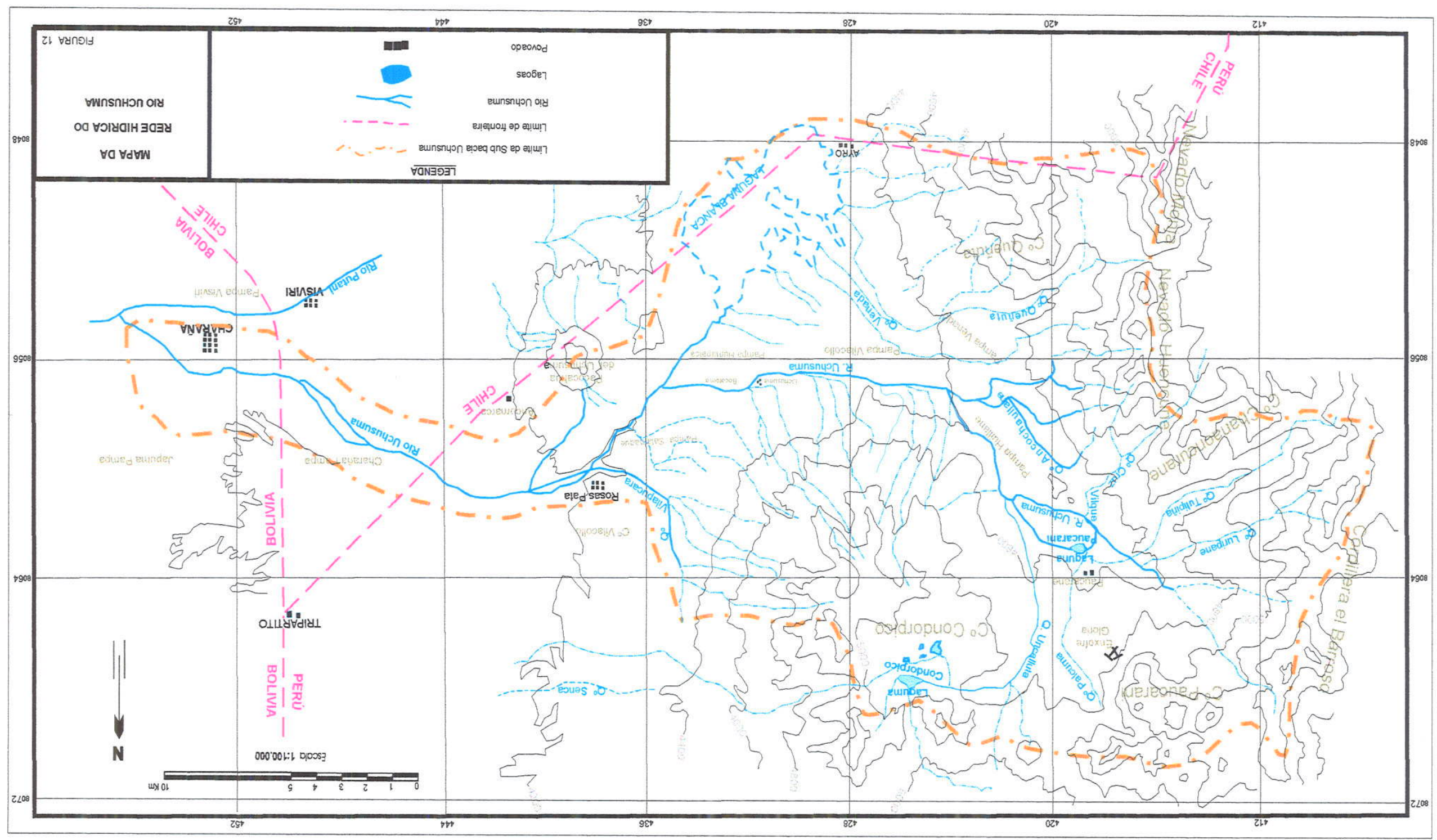


demostrar que o Altiplano tem-se desenvolvido no domínio de forças compressivas horizontais, vinculadas a longas fases de compressão que atuaram na estruturação da Corditheira dos Andes (ROEDER,1988; SEMPERE et al, 1990). Porém, os dois modelos não explicam, satisfatoriamente, a acumulação de grandes espessuras de formações do Cretáceo superior a Terciario no Altiplano em relação a sua geometria e o caracter endorreico da bacia.

Do mesmo modo, quanto ao conhecimento da evolução geomorfológica do Altiplano Ocidental, diferentes trabalhos realizados desde SIRVAS (1964); SIRVAS y TORRES (1966); PONCE (1977); BLANCO (1980), trataram de explicar alguns aspectos relacionados ao período de formação dos depósitos da Formação Charaña da Bolivia (depósitos quaternarios) e sua relação com a evolução do rio Uchusuma. Segundo estes pesquisadores, na fase final da evolução dos Andes (Quaternário), no Altiplano Ocidental desenvolveram-se bacias sedimentares a altitudes entre 4000 a $4600 \mathrm{~m}$ próximo à cadeia de vulcões, onde foram depositados sedimentos que correspondem a Formação Charaña na Bolívia

Segundo BLANCO (1980) o desenvolvimento geomorfológico da sub-bacia Uchusuma e seu entorno, iniciada no Pleistoceno, após à interrupção do aporte de materiais detríticos provenientes da cadeia vulcânica, houve intensa atividade geodinâmica sobre os materiais fluvioglaciais acumulados na zona do Ayro e zona de Charaña, que teriam definido a configuração morfológica atual da sub-bacia. Neste trabalho, (BLANCO Op cit ) descreve três períodos de peneplanização no Altiplano ocidental, onde cada uma das fases está representada por depósitos fluvioglaciais acumulados em diferentes altitudes, as quais estão vinculadas às variações do nível de base do sistema hídrico. Estes explicam os ciclos de erosão como o aprofundamento de vales e desenvolvimento das características geomorfológicas atuais.

\subsection{0.- Feições principais do relevo local.}

Na FIGURA 13 (p:45) são apresentadas as características geomorfológicas da subbacia do rio Uchusuma: 


\section{a).- Vales.}

A evolução geomorfológica local está associada diretamente à ação do rio Uchusuma e seus principais tributários como Queñuta e Vilapucara que atuaram sobre as formações geológicas presentes na área 1 e área 2.

Na zona da "Cordilheira el Barroso", um conjunto de pequenos riachos nascem em altitudes acima de $4800 \mathrm{~m}$. Esta área apresenta uma topografia escarpada produto da intensa ação geodinâmica mostrando vales glaciais alongados, depósitos de morainas no fundo dos vales, lagos glaciais como o Tiapujo e Paucarani.

Na zona do Ayro (área 1) o vale do rio Uchusuma apresenta um perfil transversal estreito, e a jusante, adota formas escarpadas trabalhadas sobre ignimbritos; no fundo deste vale mostram-se depósitos atulhados de blocos e acumulações grosseiras.

Nos territórios chileno e boliviano o rio apresenta um perfil de vale maduro (FOTO 1) e, nas zonas baixas, próximo à confluência com o rio Putani, tem-se desenvolvido planícies aluviais de relevo sub - horizontal onde se encontra assentado o povoado de Charaña. Esta superfície possui um caimento suave para SE.

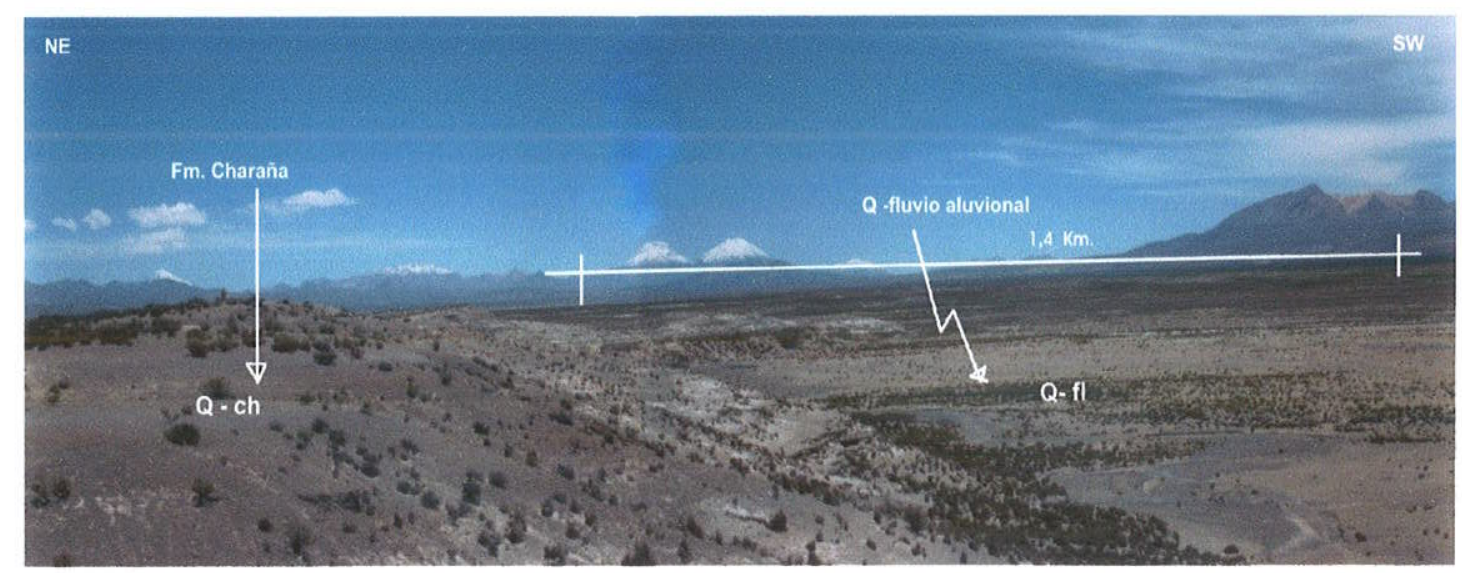

FOTO 1 - Perfil do vale do rio Uchusuma nas planícies de Visviri e Charaña- Bolívia 


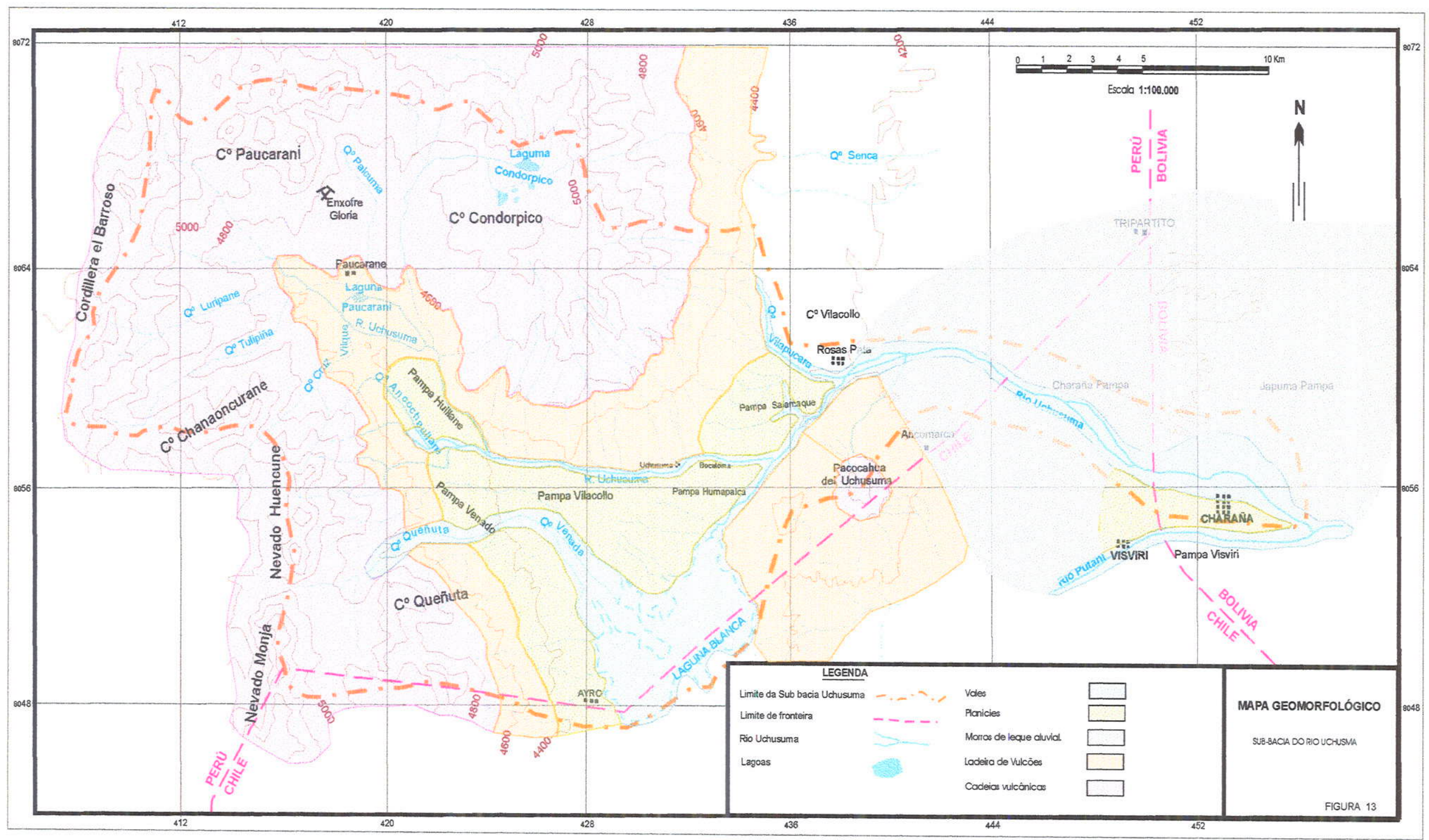


A rede hidrográfica local, está composta por numerosos rios, riachos e córregos, interligados de tal forma que toda a água a ela afluente é drenada através de um único vale que constitui o rio Uchusuma. No trajeto recebe aportes importantes da lagoa Paucarani, Tiapujo, boçorocas naturais Vilapucara e Queñuta, que são responsáveis pela manutenção dos ecossistemas locais.

\section{b).- Planícies}

No âmbito da área de pesquisa é bastante conspícuo a presença de planícies acima dos $4500 \mathrm{~m}$, que contrastam com a topografia abrupta e escarpada da cadeia vulcânica. Estas planícies começam a exibir-se no sopé da Cordilheira "El Barroso", estendendo-se a jusante do rio Uchusuma (FIGURA 13, p: 45).

Geologicamente, estas planicies tem-se desenvolvido sobre coberturas de material fluvioglacial ou aluvional do Quaternário e superfícies de erosão das formações Charaña, Capillune e Chiuchiu.

Localmente estas planícies são conhecidas com o nome de "pampa", destacandose na área 1 as planícies de El Ayro: Huapalca, Salamaque, Vilacollo, Venado e Huillane, no Peru, e no Chile as planícies Humancahua Pampa, Charaña Pampa e Pampa Visviri; na Bolívia planície de Charaña e Japuma Pampa. (FOTo 2). Alguns locais destas planicies apresentam afloramentos de mananciais, que na maioria dos casos, formam zonas hidromorficas, estando sua ocorrência relacionada a pouca profundidade das águas subterrâneas e fluxos sobre superfícies impermeáveis.

Segundo as sondagens geofísicas, a espessura destas camadas não ultrapassam os $14 \mathrm{~m}$.

\section{c).- Morros de leque aluvial..}

Na imagem de satélite LANSAT (FIGURA.14, p: 51) são evidentes os depósitos de leque aluvial acumulados entre o rio Uchusuma e Rio Kaño que corresponde à zona de fronteira do Peru e Bolivia. Nestas acumulações os fenômenos erosivos têm desenvolvido uma drenagem do tipo dendritico fino. $O$ aprofundamento de alguns canais ou cursos de rios foram gerando morros, ou colinas, de diferentes 
altitudes, com um caimento suave em direção E-SE, sendo esta uma característica particular desta área

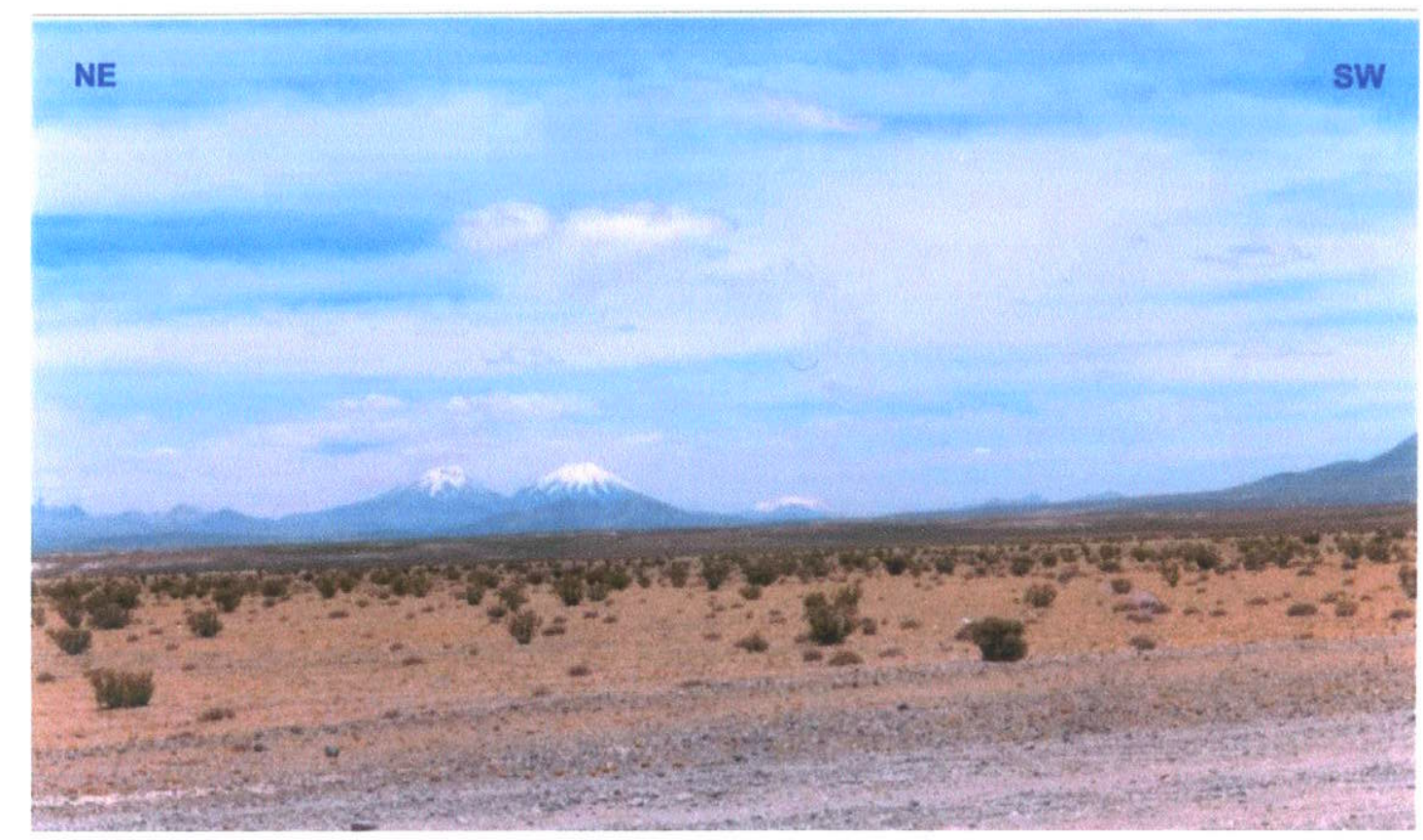

FOTO 2 - Planícies de Charaña e vulcão Payachata - Bolívia

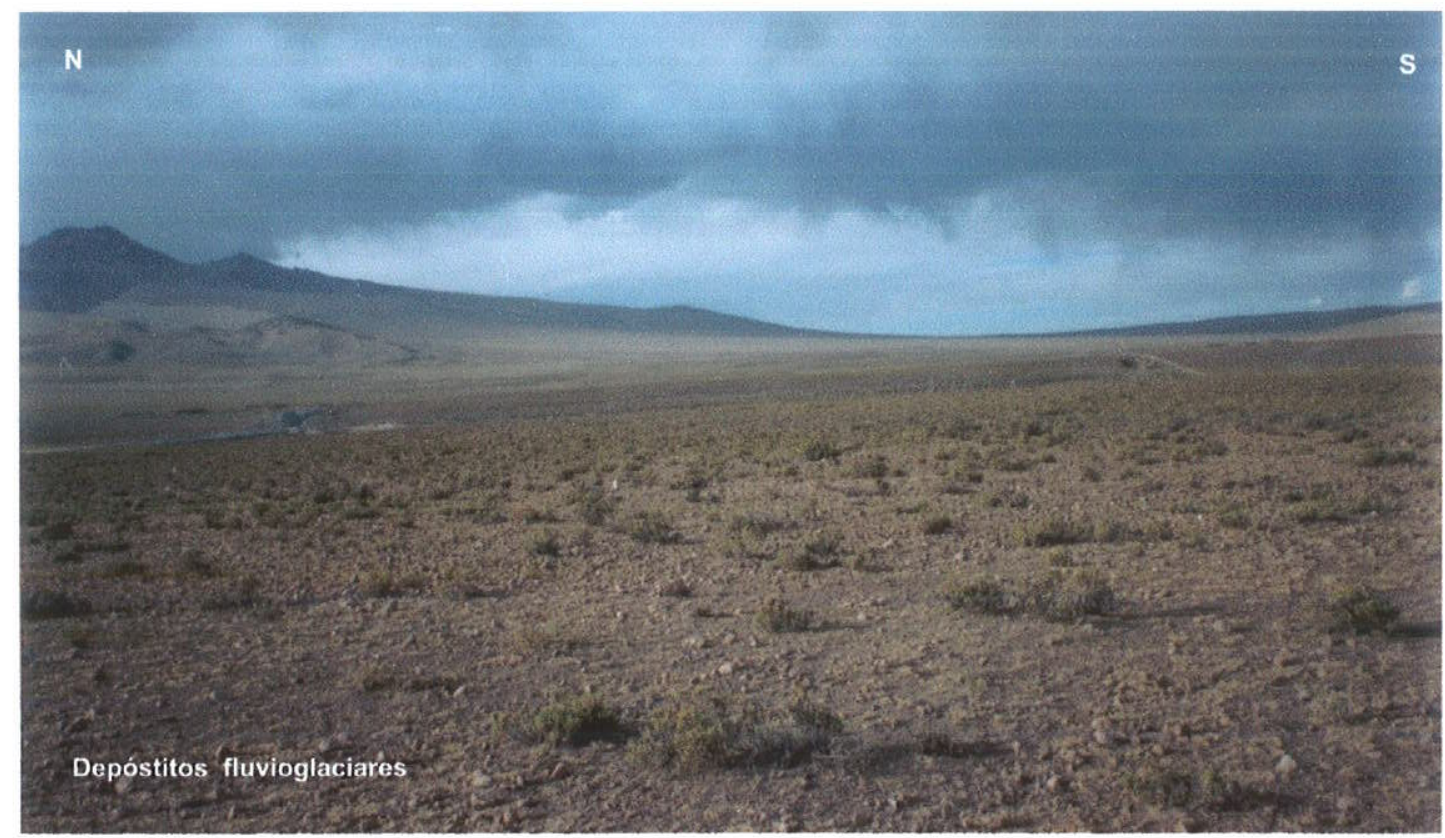

FOTO 3 - Zona de planície e ladeiras de montanha - Vilacollo - Peru 


\section{d).- Ladeiras de vulcões}

A montante do rio Uchusuma, a Cordilheira "El Barroso" apresenta uma topografia escarpada de serra por causa da intensa erosão glacial, com declividade maior do que 45 graus, e secionadas por fraturas, depressões, ressaltos estruturais. Esta característica é própria de uma zona de forte ação geodinâmica, cujos materiais erodidos e desprendidos do paredão encontram-se acumulados no sopé dos nevados, e sua composição granulométrica varia desde blocos de $1 \mathrm{~m}$ de diâmetro, a materiais de granulometria fina. Sua formaçăo está relacionada a uma influência estrutural e também a processos erosivos. Observa-se que o desnivel em zonas baixas diminuem até as proximidades das planícies (FOTO 3, p:47).

\section{e).- Cadeias vulcânicas.}

Entre os paralelos $16^{\circ}$ e $20^{\circ}$ de latitude sul, a Cordilheira Ocidental dos Andes caracteriza-se por apresentar um predomínio de estrutura de vulcões que ultrapassam os $5.000 \mathrm{~m}$ seguindo um alinhamento estrutural N -S ou NW - SE.

Esta expressão morfoestrutural, em algumas áreas, apresenta-se agrupada formando corditheiras de vulcões. Localmente, no limite da sub-bacia lado oeste, destaca-se a cadeia de vulcões extintos do "Sistema de Cordillera el Barroso", constituída por rochas de derrame vulcânico de natureza andesítica, piroclastos, brechas de talus e ignimbritos pertencentes à Formação do Vulcanico Barroso.

Do ponto de vista estrutural, o alinhamento de cones vulcânicos da "Cordillera el Barroso" está ligado a uma falha regional que segue direção $N, N E$, com deslocamentos por falhas transversais.(FIGURA 17, p: 68)

A geoforma dos vulcões exibem uma topografia abrupto na âmbito local, característica que está relacionada à intensa atividade geodinâmica do período Pleistoceno. Na maioria dos casos, não é possivel reconhecer a cratera dos vulcões por se encontrar completamente destroçada por fenômenos erosivos.

A altitudes entre 4200 e $4500 \mathrm{~m}$ é freqüente a presença de depósitos de morainas glaciais compostas por materiais de diferentes granulometrias que mostram facetas planas, polidas e estriadas pelo transporte glacial. As geoformas vinculadas à ação glacial são conspícuas nestas áreas como circos e numerosas 
vales glaciais, que predominam acima dos $4.600 \mathrm{~m}$. Na imagem de satélite LANDSAT (FIGURA 14, p: 53) o maciço montanhoso apresenta-se nitidamente formando grandes elevações com acumulação de neve permanente. Esta cadeia de montanhas constitui o divisor das águas do Pacífico e do Altiplano. Destacamse, por sua estrutura os vulcões extintos de Condorpico, Paucarani, Auquilaipe, Chila, Barroso, Huencune e La Monja no Peru, Ancotaque na Bolívia e Payachata no Chile.

Hidrogeológicamente, a configuração morfológica dos vulcões, aspectos estruturais e a natureza dos materiais, contribuem na recarga dos aqüiferos nesta área. Nos altos cumes, ou entorno dos nevados, pode-se observar que as águas de precipitação, ou de degelo de neve deslocam-se formando pequenos riachos, e parte delas infiltram-se através dos planos de contato de estratificação de derrames de lava, camadas de piroclastos de alta porosidade e diaclases alcançando grandes profundidades. Uma fração destas águas emergem por circulação subsuperficial como mananciais de caracter temporário ou permanente nas zonas topográficas baixas ou vales.

\subsection{0.- Geologia regional}

A geologia regional do altiplano está associada à evolução tectônica e sedimentar da bacia, iniciada no Paleoceno-Eoceno (MARTINEZ et al.,1997) com o sobrecorrimento (cavalgamento) do maciço de Arequipa (Peru) sobre o Craton de Guaporé (Bolívia), localizada na zona de falha da Cordilheira Real. $O$ cavalgamento tem gerado encurtamentos progressivos e contínuos na bacia do Altiplano. Esta tese é uma conseqüência dos trabalhos MARTINES \& HEUSCHMIDT, (1994), sobre a evolução da tectônica dos Andes, indicando que os grandes eventos da evolução da Cordilheira dos Andes, definidos como fase Inca e fase Quechua no Peru, correspondem a etapas de máxima compressão que teve efeitos sobre a bacia do Altiplano. Os materiais acumulados nesta região são resultantes do processo da evolução sedimentar desde o Cretáceo superior ao Pleistoceno, de máxima desenvolvimento geomorfológico registrado no Altiplano, e, na maioria dos casos, encontra-se afetado por dobras e falhas que, em vários setores do Altiplano, podem estar associadas a estruturas petroliferas (ARANIBAR, 1995). 
O relevo regional apresenta um predomínio de controle estrutural. Observam-se anticlinais formando serranias, e sinclinais alinhados que guardam relação com o rumo dos vales e zonas topográficas baixas. Dentro deste panorama observa-se um predomínio de planícies preenchidas por depósitos fluviais, lacustres, fluviolacustres, glaciais e aluviais recentes, niveladas por ação fluvial.

$\mathrm{Na} z o n a$ da Cordilheira Ocidental dos Andes o Instituto Geológico Minero Metalúrgico do Peru fez diversos levantamentos de interesses geológicos. Dentre os mais importantes destacam-se os trabalhos de JENKS (1946) e NEWELL (1949), que deram a conhecer a estratigrafia desta região. Pesquisas posteriores, como de JONG (1974); PORTUGAL (1974), definiram os lineamentos estruturais e estratigráficos. Anos depois LAUBACHER (1978) estabeleceu a estratigrafia paleozóica do Altiplano, e LAVENU (1992) realizou estudos de depósitos terciários, quaternários na bacia do lago Titicaca. Estudos mais recentes abordam a Geologia de Cordilheira Ocidental (KLINCK, et al.,1993).

\subsection{0.- Estratigrafia da sub-bacia Uchusuma}

Nos limites da sub-bacia do rio Uchusma, exibe-se um predomínio de formações sedimentares, e vulcânicas, afetadas intensamente por uma tectônica rúptił. Nesta região o Instituto Geológico Minero Metalúrgico do Peru (INGEMMET), Servicio Nacional de Geología y Minería do Chile (SERNAGEOMIN) e Servicio de Geología y Minería da Bolivia (SERGEOMIN) fizeram diversos levantamentos de interesses geológicos. Porém, o conhecimento atual da geologia desta área carece de exatidão e detalhe no mapeamento das unidades estratigráficas.

A complexidade das caracteristicas geológicas e a falta de inter-relação das unidades cartografadas pelos três países fronteriços, dificultou o estabelecimento de uma correlação de dados desta zona, e por esta razão, determinou-se o levantamento geológico das formações plio-quaternarias em escala 1:50.000 com apoio de imagem satélite de LANDSAT banda 7,4,2, (FIGURA 14, p:53), utilizando nomenclaturas estratigráficas próprias de cada país, para manter sua representatividade e estabelecer correlações estratigráficas entre formações geológicas das diferentes folhas cartografadas. A informação toda possibilitou 
uma caracterização geológica da sub-bacia e elaboração da coluna estratigráfica local.

De modo geral, o quadro geológico da bacia hidrográfica do rio Uchusuma está constituído por rochas sedimentares e vulcânicas com idades do Plioceno até o Quaternário recente. (FIGURA 15, p:54)

Formação Maure (Tp - ma) no Peru, Fm. Mauri na Bolívia. (Oligoceno; Mioceno)

O nome de Formação Maure (Peru) foi designado por WILSON \& GARCIA (1962) e como Formação Mauri na Bolivia por (DOUGLAS, 1914; AHLFELD, 1946), para rochas que afloram na área do rio Mauri (Norte da Bolívia). Posteriormente, SIRVAS \& TORRES (1966), dividiram esta unidade em seis membros nos trabalhos realizados na localidade de Santiago de Machaca e Berenguela. As características litológicas são:

\begin{tabular}{|c|c|c|}
\hline Unidade & Litologia & Espessura \\
\hline $\begin{array}{c}6 \\
\text { Topo da Formação. }\end{array}$ & $\begin{array}{l}\text { Intercalação de conglomerado, arenitos e pequenas camadas de ignimbritos de } \\
\text { cor branca }\end{array}$ & \\
\hline 5 & Conglomerados e arenitos de origem vulcânica de cor cinza e verde-cinza & $300 \mathrm{~m}$ \\
\hline 4 & Derrame de lava de cor cinza escura & $15 \mathrm{~m}$ \\
\hline 3 & Intercalaçào de arenitos de cor cinza-clara de origem vulcânica e conglomerados & $90 \mathrm{~m}$ \\
\hline 2 & Interestratificaçäo de lavas de cor marrom-escuras, lavas roxas e ignimbritos & $60 \mathrm{~m}$ \\
\hline $\begin{array}{c}1 \\
\text { Base da Formação }\end{array}$ & $\begin{array}{l}\text { Vulcano detritica, arenito basal friável de gräo fino a médio, cor violácea com } \\
\text { estratificaçäo cruzada }\end{array}$ & $100 \mathrm{~m}$ \\
\hline
\end{tabular}

A amplitude do domínio da Formação Mauri, na Bolívia, está caracterizada pela extensão dos terrenos pliocênicos e pleistocênicos pouco deformados, donde foram caracterizadas duas bacias: oriental e ocidental (HÉRAlL et al., 1997). Esta seqüência de estratos foram pesquisadas desde KOLZLOWSKI (1918), AHLFELD Y BRANISA(1960) LAVENU et al (1985).

No Peru, os afloramentos da Formação Maure foram cartografados por INGEMMET desde a latitude de $14^{\circ}$ sul (Folha $29-Q$ de Antabanba) a $18^{\circ}$ sul (Folha 36-X de Palca) FIGURA 16 ( $p: 55$ ). Por suas caracteristicas esta bacia segue um alinhamento estrutural NE-SE. 
$\mathrm{Na}$ zona do lago Titicaca, entre as localidades de llave e Juli, atinge uma espessura de $1.300 \mathrm{~m}$ composta por camadas interestratificadas de arenitos de cor verde escura, com alto conteúdo de clorita, conglomerados, cinza vulcânica, camadas de ignimbritos, siltitos, argilitos e calcários. Esta seqüência foi depositada em um ambiente lagunar, de subsidência facilitando acumulação de sedimentos e piroclásticos acompanhados de atividade vulcânica regional (KLINCK et at 1993)

Estratigraficamente, a Formação Maure foi eleva à categoria de Grupo por KLINCK Op Cit), considerando dentro desta a varias formações tais como Maure, Sencca, Capillune e Quemillone no Peru. Esta proposta é muito discutida por falta de maiores dados.

Localmente a Formação Maure constitui a unidade mais antiga descrita por MENDIVIL (1965) na folha de Antajave-Tacna, e, no âmbito da sub-bacia, apresenta um conspícuo afloramento no corte transversal do vale Vilapuraca com rumo N318E, e mergulho 25 SW. Na colina Pacocahua de Uchusuma apresentase seguindo um rumo norte - sul e mergulho entre $25^{\circ}$ a $30^{\circ}$ oeste. Em áreas adjacentes à sub-bacia e nas proximidades ao rio Maure e zona de fronteira entre Peru e Bolivia, esta formação apresenta-se com mergulho $24^{\circ}$ a $35^{\circ}$ a SE.

Nos registros de poços perfurados (zona do Ayro - Peru), foi reconhecida uma seqüência interestratificada de horizontes de $0,60 \mathrm{~m}$ de espessura conformada por arenitos quartzosos de granulometria variada, siltitos de cor verde escura, pequenos horizontes de piroclastos, conglomerados, cinza dacítica de cor branca amarela e argilitos. A espessura desta formação, no poço de Charaña, é de 110 $m$. As características sedimentares evidenciam que essa formação foi depositada em ambiente lagunar, interrompido por acumulações de materiais de atividade vulcânica.

$\mathrm{Na}$ imagem de satélite apresenta uma resposta espectral em uma tonalidade verde amarelo pálido. Hidrogeologicamente, constitui o aqüífero de interesse regional e de ampla distribuição no Peru e na Bolívia. 


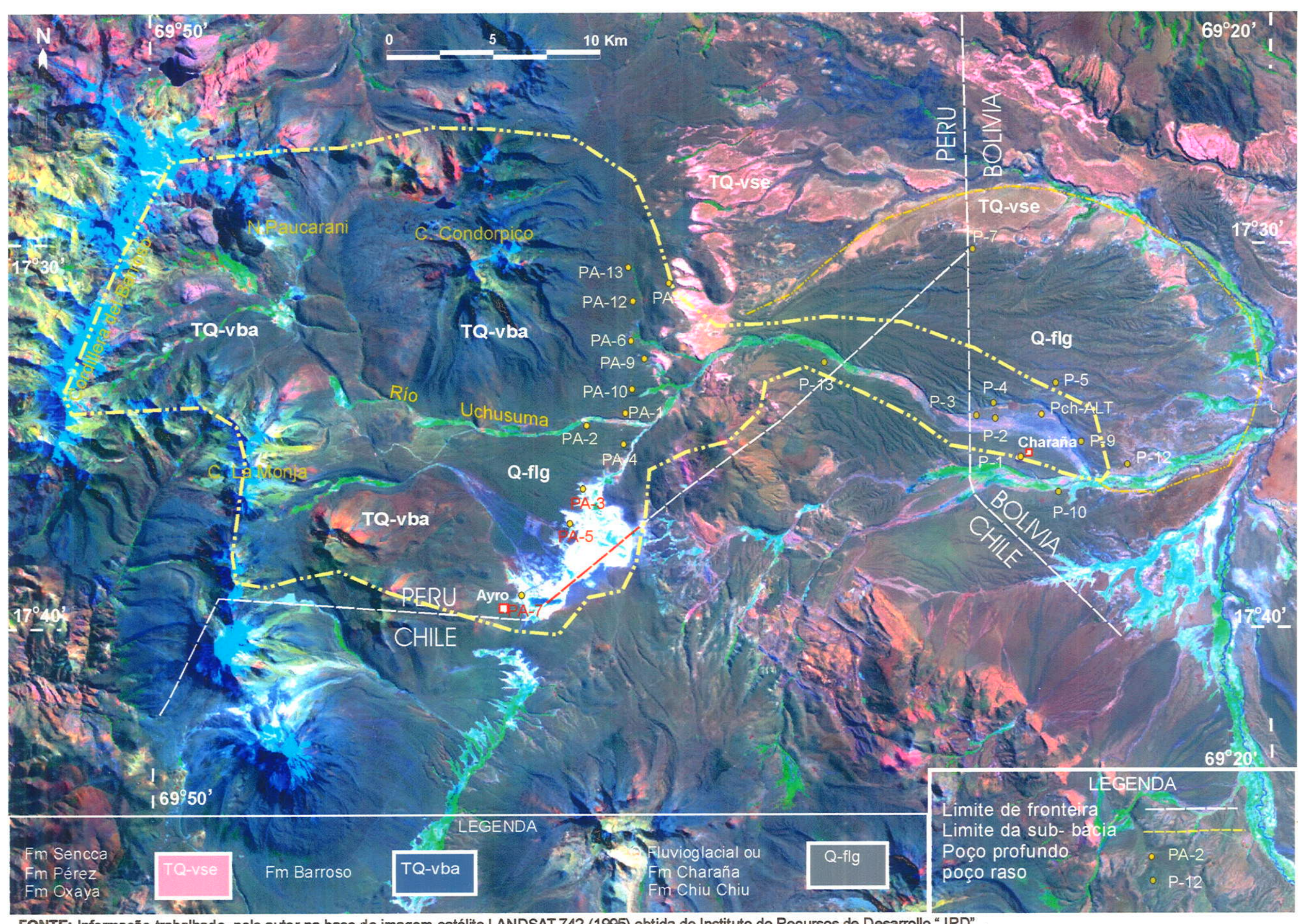

FONTE: Informação trabalhado pelo autor na base de imagem satélite LANDSAT 742 (1995) obtida do Instituto de Recursos de Desarrollo “ IRD” . 

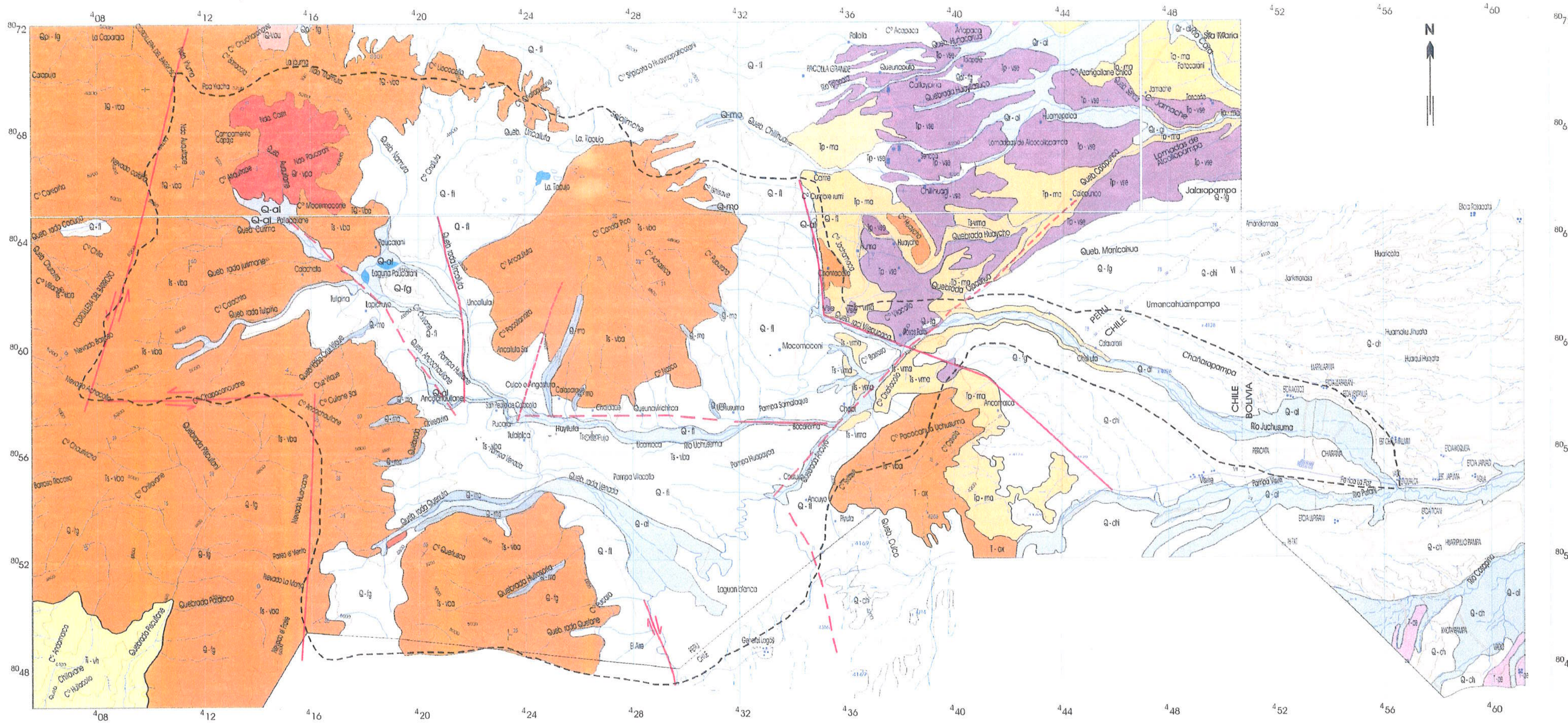

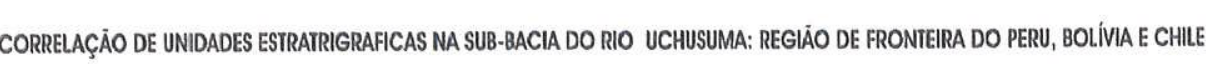

\begin{tabular}{|c|c|c|c|c|c|c|c|c|c|c|c|c|}
\hline \multirow{6}{*}{\multicolumn{2}{|c|}{ 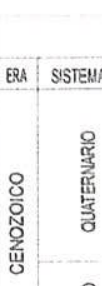 }} & \multicolumn{3}{|c|}{ PERU } & \multicolumn{2}{|c|}{ 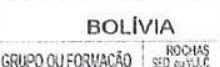 } & \multirow{2}{*}{\multicolumn{2}{|c|}{ 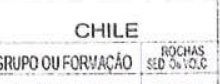 }} & \multirow{2}{*}{\multicolumn{4}{|c|}{ LEGENDA }} \\
\hline & & SSRE & 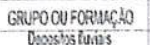 & 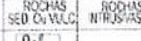 & 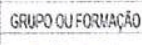 & & & & & & & \\
\hline & & & 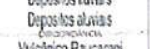 & a & Onstoratwas & [0.al : & 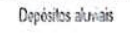 & [0.81 & & Rumo e mergulho & & Falha provável \\
\hline & & 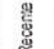 & 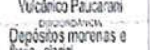 & 19.6. & Fn Cusiag & 0 & 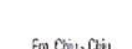 & (n.diti & & Camada horizontal & . & Eixo anticlinal \\
\hline & & & 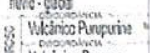 & 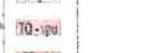 & & & & & & Direção do fluxo & $\beta$ & Eixo sinclinal \\
\hline & & & 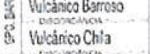 & 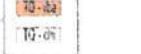 & & & & & & Contato conhecido & & Estrada afirmada \\
\hline & 簽 & $\frac{6}{8}$ & 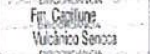 & inat & Fm.Peger & TT:De0] & Em: oispa & Fine & & Contato aproximado & & Estrada \\
\hline & & & sm. hever & [5.:日] & Fm.havin & {$[x=0]$} & & & & & & Limite da bacia Uchusum \\
\hline
\end{tabular}

MAPA GEOLÓGICO DA SUB-BACIA DO RIO UCHUSUMA ZONA DE FRONTEIRA PERU - BOLIVIA - CHILE 
FIGURA16 - ABRANGÊNCIA DA BACIA SEDIMENTAR DAFORMAÇÃO MAURE NO ALTIPLANO

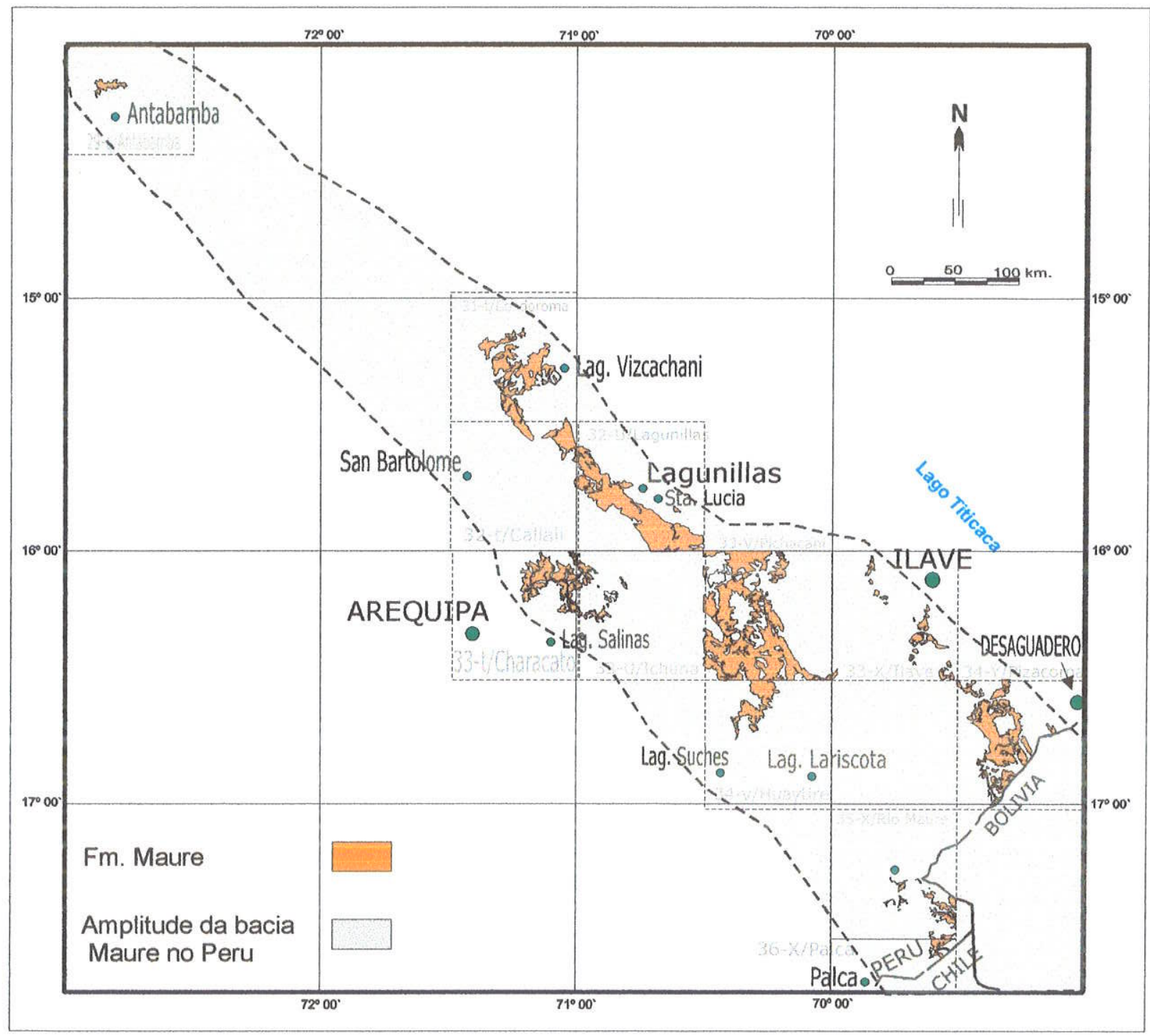

Formação vulcânico Sencca no Peru (Tp-vse) e Formação Pérez na Bolívia (T-pe) e Formação Oxaya no Chile

No Plioceno, a sedimentação da Formação Maure, sofreu uma interrupção pela atividade dos vulcões da zona sul do Peru, acumulando materiais piroclásticos de grande espessura, e soterrando uma grande extensão dos depósitos da Formação Maure como um manto horizontal. Esta unidade foi descrita pela primeira vez por MENDIVIL, (1965) na área de Maure-Peru. Na Bolívia eqüivale à Formação Pérez, descrita por SIRVAS E TORRES (1966). No Chile esta unidade aflora entre os paralelos $18^{\circ}$ e $22^{\circ}$, reconhecida como "Ignimbritos del Norte de Chile" de idade pliocénica, que repousa debaixo de inúmeras camadas de 
estratos vulcânicos (BRUGGEN in MOYRA et al, 1985). Inicialmente foram designados diferentes nomes como Formação Altos de Pica (GALLI \& DINGMAN in Carta Geológica de Chile 1962) Formação Oxaya (SALAS et.al 1966) e Formação San Bartolo (HOLLINGWORTH \& RUTLAND, 1968). Posteriormente PASKOFF \& NARANJO (1983) descreveu esta unidade vulcânica como Formação Oxaya.

Litologicamente está constituída por tufitos, fragmentos de bomba, pomes, vidro e brechas heterogêneas. Estas rochas são portadoras de abundante quartzo de cor branca a rosa e, em conjunto, são de natureza alcalina, dacítica a riolítica sobresaturado de sílica. Por seu alto conteúdo de minerais de potássio são conhecidas como ignimbritos Senca ou Pérez. Esta formação caracteriza-se por seu comportamento a efeitos de meteorização, mostrando uma marcada disjunção colunar prismática, desenvolvendo figuras de formas variadas (FOTOS 4 , $5 \mathrm{p:} \mathrm{57).}$

Nos afloramentos apresenta uma coloração cinza a branca e amarela a marrom pálido. Em superfície intemperizada mostram uma cor amarela a marrom escura. Esta formação está distribuida ao longo de dezenas de quilômetros em camada horizontal como no lugarejo Senca, $C^{\circ}$ Vilacollo, e alonga-se em direção NE, passando por lugarejo Humapalca, N - NE do lugarejo Tripartito. O afloramento mais representativo no lado boliviano observa-se no local "Ciudad de Piedra", ao N.W. do povoado de Charaña (próximo ao rio Kaño), com uma espessura de 24 m. Durante a perfuração do poço de Charaña- Bolívia, no ano 2000, esta formação foi identificada a uma profundidade de $58 \mathrm{~m}$ com uma espessura de 25 $m$. Segundo os estudos feitos por MENDIVIL (1965) a máxima espessura desta formação è de $80 \mathrm{~m}$.

$\mathrm{Na}$ imagem de satélite é nítida esta formação por apresentar uma resposta espectral característica de uma tonalidade marrom pálida a amarela (FIGURA 14, p: 53) 


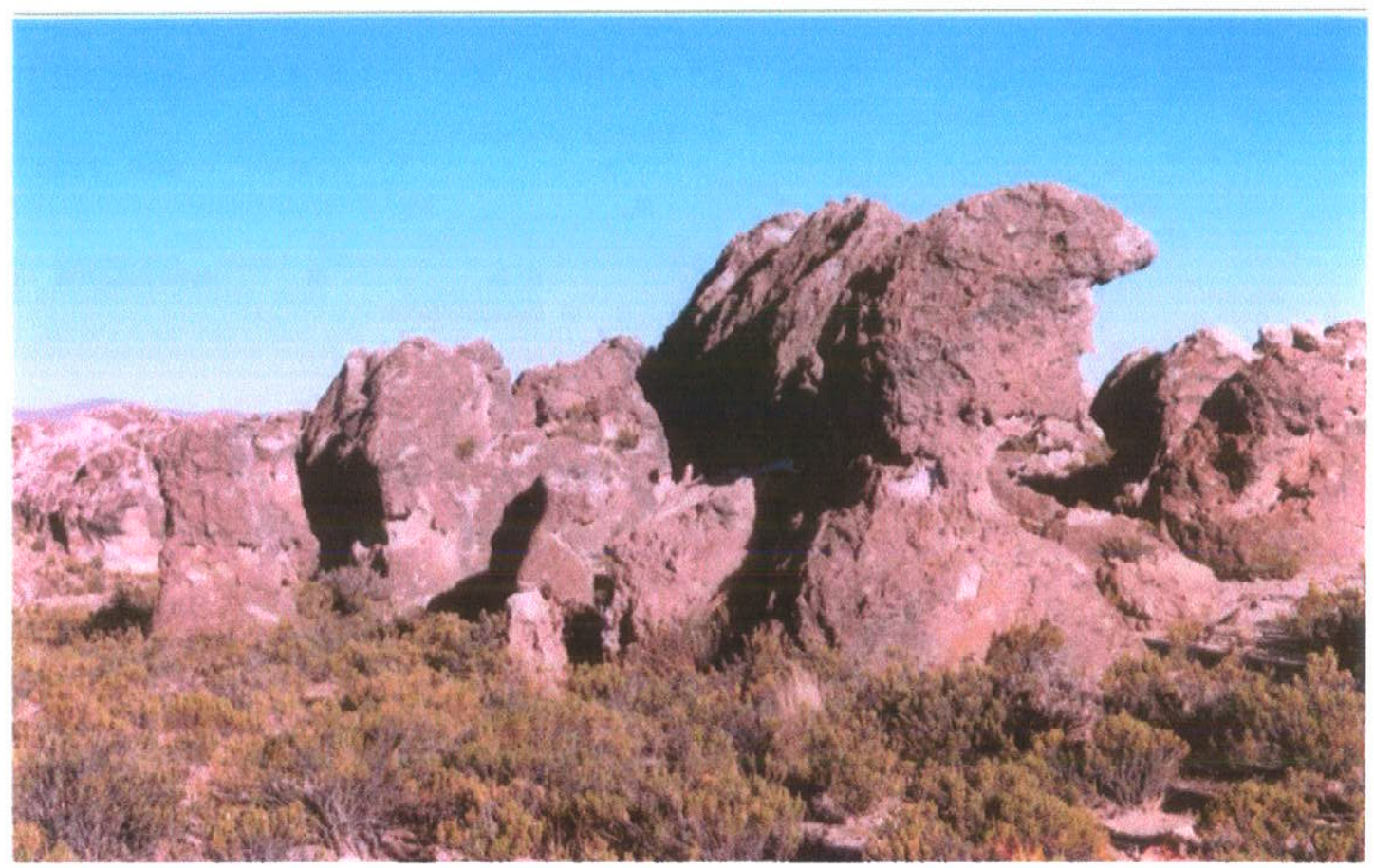

FOTO 4 .- Formação Sencca no Peru, Formação Pérez na Bolívia e Formação Oxaya no Chile (Local Ciudad de Piedra - Charaña Bolivia)

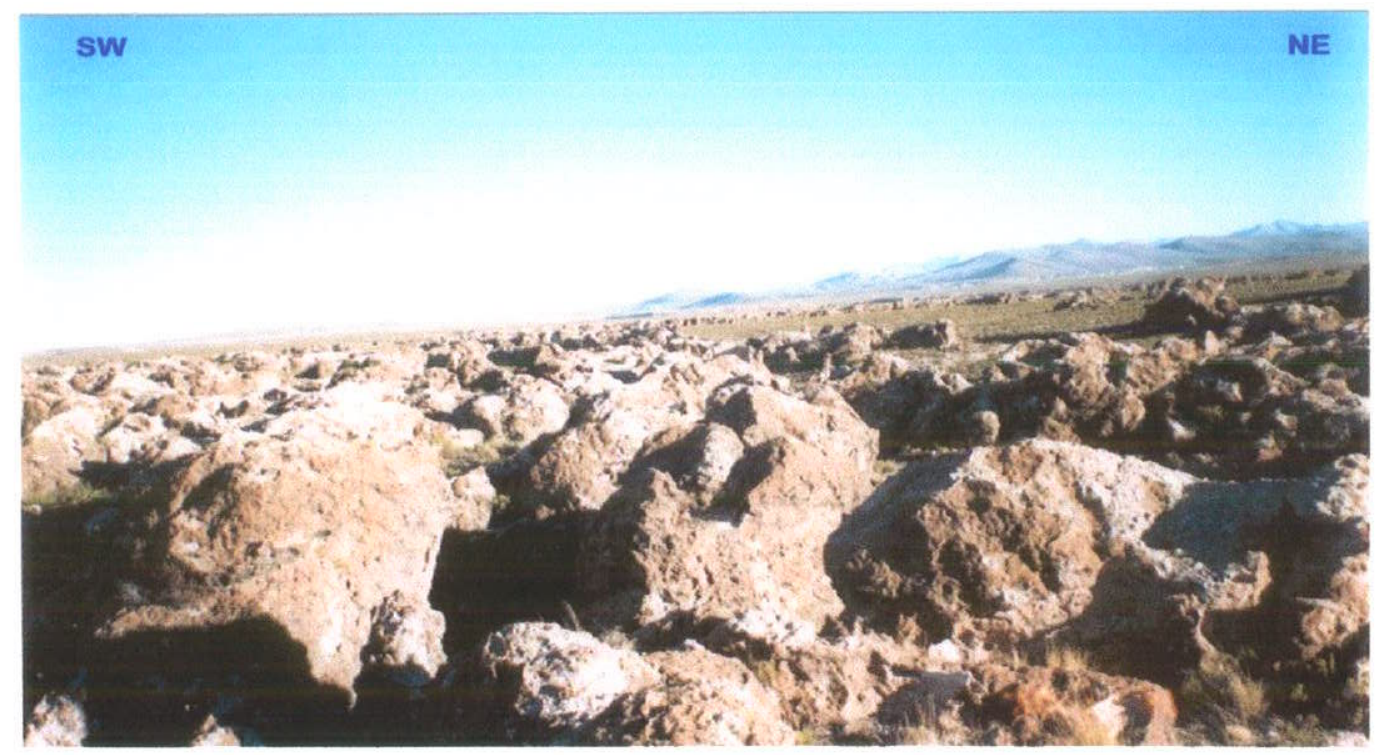

FOTO 5.- Afloramento da Formação Sencca próximo ao Rio Kaño na Bolívia. 
$\mathrm{Na}$ literatura são conhecidos como ignimbritos as rochas de natureza piroclástica que apresentam uma estrutura maciça de fragmentos alongados e orientados em matriz tufítica sem estratificação e gradação de características variadas, no tocante a petrografía, estrutura, e extensão areal (HORSTPETER 1986).

Regionalmente os ignimbritos Sencca constituem uma formação guia por sua ampla distribuição que marca o começo da grande atividade do vulcanismo plioquaternario que consegue soterrar as formações do Mioceno (DALMAYRAC 1988). Estruturalmente encontra-se afetado por falhas e fraturas, e esta característica controla e define o comportamento hidrogeológico da Formação Maure.

\section{Formação Capillune (Tp-ca)}

Após o período de atividades vulcânicas do Plioceno que originaram os ignimbritos da Formação Sencca, na depressão do Altiplano reiniciou-se uma nova fase de acumulação de sedimentos em ambiente lagunar, de características litológicas semelhantes à Formação Maure, seqüência que foi reconhecida com o nome de Formação Capillune (Mendivil 1965).

Esta formação encontra-se amplamente distribuída, na zona de fronteira do Peru, Bolívia e Chile.

Nos trabalhos de prospeção realizados pela ex- Empresa de Mineração Southern Peru Copper Corporation na área de "Pamapas de Huaitire, Viscachas", jurisdição de Moquegua e Puno do Peru, foi determinada uma espessura de $500 \mathrm{~m}$ da Formação Capillune no altiplano.

Na sub-bacia de Uchusuma (Área 1) a Formação Capillune não apresenta afloramentos, porém foi identificada nos perfis dos poços perfurados, PA-1, PA-2, PA-3, PA-4, PA-10 (ANEXO II), com espessuras que variam entre 11 a $24 \mathrm{~m}$ até uma máxima de $210 \mathrm{~m}$, nos poços PA-5 e PA-7, que corresponde a um paleovale soterrado por sedimentos da Formação Capillune e materiais fluvioglaciais. Litologicamente está composta por um conjunto sedimentar do tipo lacustrino fluvial, intercalado por camadas vulcano-sedimentares: lapillitos em matriz tufitica, 
areias, cascalhos de diferentes granulometrias, gradando a horizontes de siltes argilosos, areias tufácea de cor branca a verde amarelo.

Os sedimentos da Formação Capillune foram depositados durante o Plioceno após acumulação dos ignimbritos da Formação Sencca. Por suas características sedimentares e estratigráficas a Formação Capillune constitui um importante aqüífero não confinado dentro da sub-bacia Uchusuma.

\section{Grupo Barroso.}

Nesta unidade agrupam-se os depósitos vulcânicos acumulados durante o Pleistoceno, resultantes da atividade dos vulcões Chila, Barroso, Chanaoncurane, Monja, Tacora e Chupiquiña, que constituem o "Sistema del Cordillera el Barroso" e cones vulcânicos isolados desta zona. De modo geral, os tipos de material acumulado por diferentes vulcões caracterizam-se por sua similitude litologia, constituído por andesitos, traquiandesitos e piroclastos de cores escuras, indicando que estes materiais correspondem a um mesmo magma expelido em diferentes episódios.

A maioria dos cones vulcânicos está edificada ou estruturada sobre derrames de lavas estratificadas e intercaladas com brechas, lapilles e tufitos, que se apresentam em camadas de diferentes espessuras, com mergulhos de alto ângulo em direção ao sopé das montanhas. Esta caracteristica estratiforme é conhecida como "estrato vulcões" resultante da acumulação sucessiva de lava e material piroclástico expelido de uma cratera ou grupo de crateras.

Estratigraficamente o Grupo Barroso está constituído por três unidades que correspondem a três etapas de vulcanismo ou emissão de material vulcânico. A mais antiga denomina-se Vulcanismo Chila, continuando o Vulcanismo, Barroso de ampla distribuição que caracteriza o grupo Barroso, e, finalmente o Vulcanismo Purupurini cujos derrames cobrem depósitos de morainas glaciais.

A litologia do Grupo Barroso é composta por rochas vulcânicas de natureza andesitica e traquiandesitica que repousam, em discordância angular, sobre superfícies de erosão Maure e Capillune. $\mathrm{Na}$ área afloram as unidades Chila, Barroso e Purupurani de ampla distribuição. Estes materiais apresentam-se 
formando estruturas vulcânicas ou como derrames de lava de várias fases de erupção.

\section{Unidade Vulcânico Barroso (TQ-vba).de idade Plio-Pleistoceno}

Vinculam-se a esta unidade um conjunto de derrames de lava de vulcões extintos, que, na atualidade, apresentamse como uma cadeia de nevados de altitudes que ultrapassam os $5.000 \mathrm{~m}$. Estas rochas afloram nos diferentes nevados como Condorpico, Paucarani, Coruña, Nevado Barroso, Achocollo, Queñuta que delimitam a sub-bacia do rio Uchusuma no extremo oeste noroeste. Também estão incluidos derrames de andesitos porfiríticos e brechas de fluxo de cor cinza escura a vermelha, expelidos por sistema de fraturas profundas, como exibido nos pequenos afloramentos do nevado Condorpico (coordenadas Lat. 80.65, 80.68, Long. 4.24 e 4.30). Nos trabalhos geológicos realizados por INGEMMET (1998) os andesitos porfiriticos foram mapeados como Formação Vulcânica Chila. Confrontando esta informação com trabalhos de campo, se correlacionou ao Vulcânico Barroso. Na imagem de satélite LANDSAT bandas 7,4,2 esta observação é bastante nitida.

As características litológicas do Vulcânico Barroso estão constituídas por lavas de natureza andesitica a traquiandesiticas de grão fino a médio, textura vesicular, de cor cinza escuro, com algumas intercalações de brechas de cores marrom, verde e cinza escura com alto conteúdo de biotita e fenocristais de sanidina.

O Vulcânico Barroso é de ampla distribuição regional e, localmente, apresenta-se afetada por erosão glacial e estruturas de cones destruidos. Os derrames de lava formam estruturas estratificadas de derrames de lava. O conjunto desta formação assenta-se em discordância erosiva sobre a Formação Maure, Sencca e Capillune.

A cadeia de vulcões extintos mostra-se nitidamente na imagem de satélite LANDSAT, bandas $7,4,2$, com uma resposta espectral de cor cinza escura a marrom. A presença de neve mostra-se em tom azul celeste, ressaltando sua borda branca. O conjunto destes nevados representam as últimas etapas de atividade de vulcanismo pleistocênico desta região. Segundo J. WILSON \& GARCIA (1962), a máxima espessura da Formação Barroso é de $1.500 \mathrm{~m}$. 
Algumas camadas de derrames de lava da Formação Barroso possuem alta permeabilidade primaria e secundaria por sua característica estratificada e mecanismo de deformação rúptil (fraturas e falhas). Esta característica favorece a infiltração e formação de mananciais de regime temporário e outras de caráter permanente, fundamentalmente favorecendo a recarga do aqüífero da Formação Capillune.

\section{Depósitos fluvioglaciais e depósitos de morainas. (Qpl -fg) no Peru, Formação Charaña na Bolívia , Formação Chiu - Chiu no Chile.}

A zona do Ayro - Peru (área 1) apresenta numerosos depósitos glaciais do Pleistoceno. Entre estes vestígios, as morainas glaciais estendem-se desde os altos cumes da serrania vulcânica até altitudes de $4.400 \mathrm{~m}$. Os materiais acumulados correspondem a moraina lateral e terminal, till de planícies e depósitos de argila fluvioglacial .

Estas morainas estão constituidas por materiais heterogêneos composto por uma mistura de argila, silte, areias, cascalhos e grandes blocos angulares a subangulares, que se mostram na encosta dos nevados que contornam a subbacia.

No sopé dos nevados da Cordilheira El Barroso, Paucarani, Monja e vales de encosta de baixo declive, os processos erosivos têm desenvolvido planícies de depósitos flúvioglaciais, desde as proximidades dos contrafortes onde observamse material de granulometria grossa, a zonas de topografia baixa constituídas por materiais de granulometria média, englobados em uma matriz argilosa, areias e silte. Na zona do Ayro (área 1) encontram-se cobrindo unidades do Grupo Barroso, depósitos das formações Capillune, Sencca e Maure (FOTO 6, P: 63). Geralmente são de pequena espessura e levemente estratificado.

$\mathrm{Na}$ área que corresponde ao território chileno e boliviano, esta formação corresponde a depósitos acumulados em ambiente lagunar por materiais provenientes da atividade vulcânica da cordilheira Ocidental dos Andes. A fase final do processo de sedimentação foi afetada por um derrame de aluviões do rio Uchusuma proveniente da área peruana 
No Chile esta unidade foi descrita por NARANJO \& PASKOF (1981) como Formação Chiuchiu. Nas planícies de Charaña Pampa e Visvire Pampa, apresenta-se sob a forma de camadas de material vulcânico brechoide, depositado em ambiente lagunar, conglomerados finos, areias semi-consolidados e pequenas camadas de calcário arenoso.

No lado boliviano foi descrito por NUÑEZ (1964) e apresenta-se como uma continuação de depósitos presentes no território chileno. O rio Uchusuma expõe excelentes afloramentos perto da confluência com o rio Putani, no local chamado "Estancia Ventilla". Neste afloramento observa-se uma seqüência sedimentar lacustrina: diatomitos interestratificados com areias e siltes, que passam, em gradação continua a seqüência de areias finas a grossas, com estratificação cruzada, microconglomerados parcialmente consolidados, seixos arenosos, camadas de cinza vulcânica em diferentes niveis e ingnimbritos, indicando que os ciclos sedimentares foram interrompidos pela atividade vulcânica. No topo desta formação apresentam-se sedimentos calcários, cascalhos e areias (FOTOS 7,8. P: $63,64)$. No poço de Charaña Bolívia, esta formação apresenta uma espessura de $24 \mathrm{~m}$.

Correlacionando as características sedimentares entre a área 1 e a área 2 observa-se uma marcada diferença litológica e no ambiente de deposição. A imagem de satélite, contribuiu na correlação. Na FIGURA 14 (p: 53), observa-se que o rio Uchusuma perto da fronteira com Chile, muda de direção para leste. A partir deste local mostra-se evidente uma superficie de espalhamento de materiais de leque aluvial, com vértice de ingresso do material flúvioglacial próximo ao lugarejo Rosas Pata ou cerro Vilacollo, e deslocamento em direção NE, cobrindo ignimbritos da Formação Sencca ou Pérez da Bolívia.

$\mathrm{Na}$ imagem de satélite (FIGURA 14, p:53 e FOTO 6, 7. P:63) é fácil a identificação dos depósitos flúvioglaciais por sua geoforma, comportamento ao processo de erosão, desenho dendritico fino, e adota um tom cinza marrom como resposta espectral. 


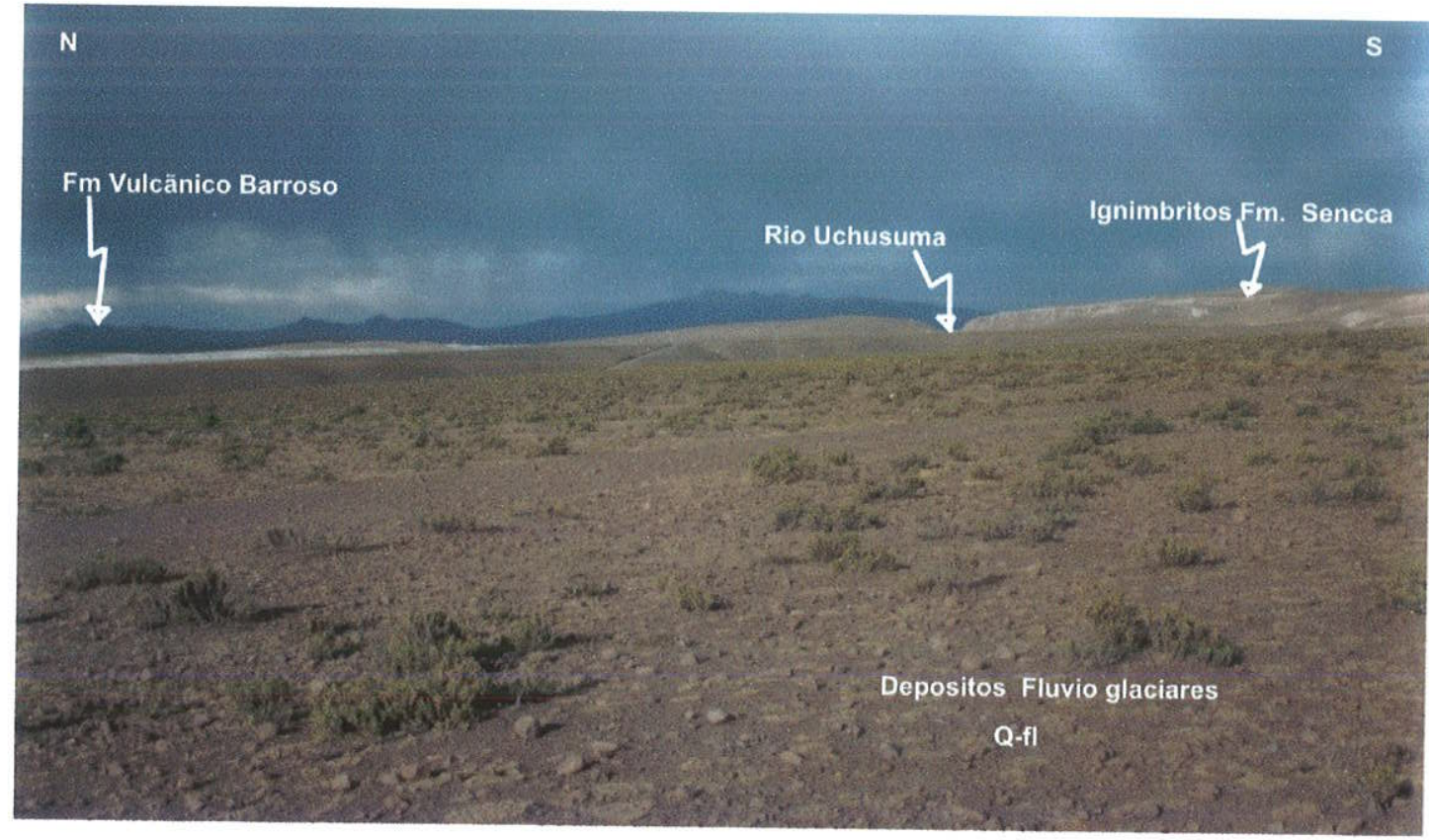

FOTO 6 - Depósitos fluvioglaciais na zona do Ayro - Peru

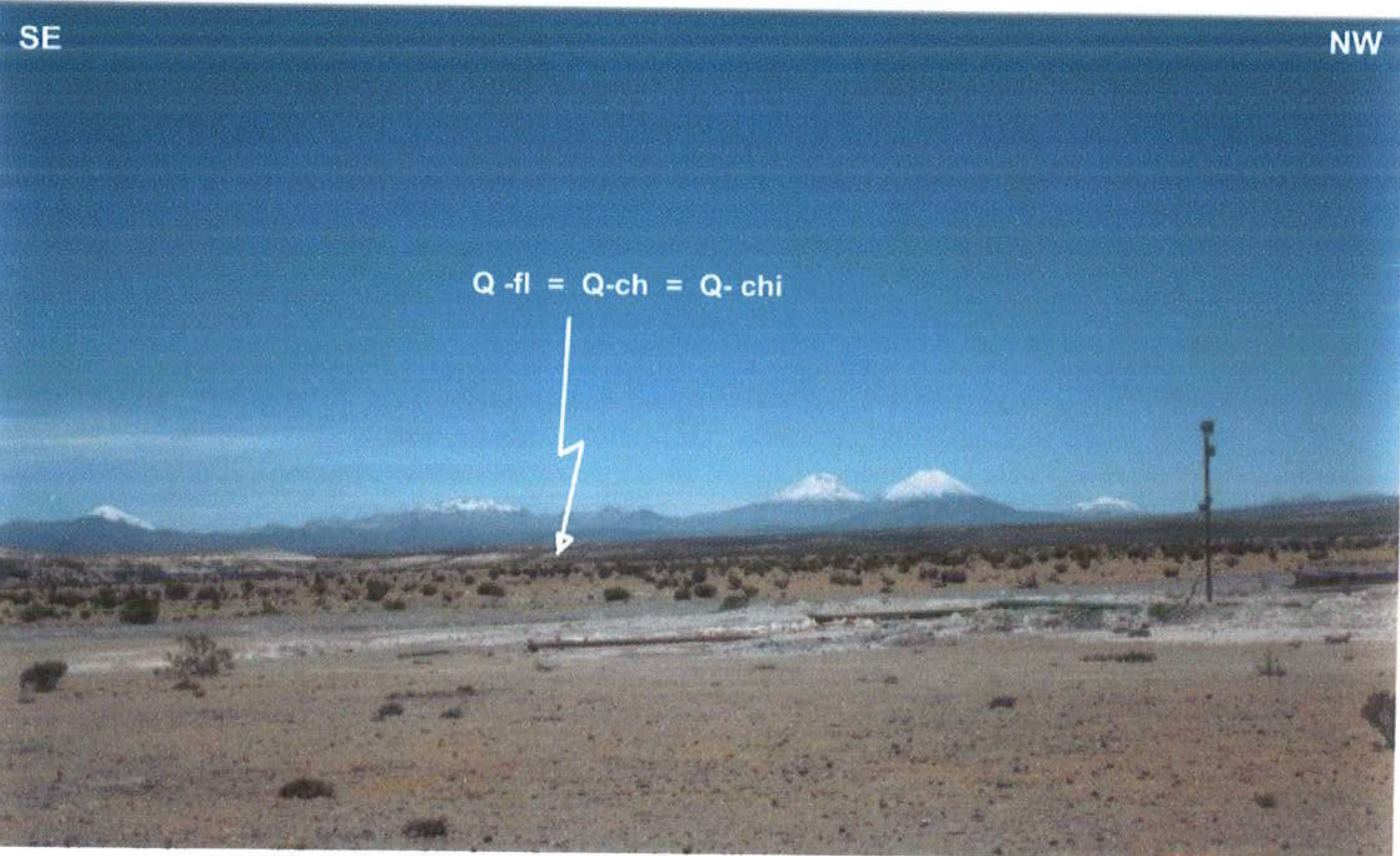

FOTO 7 - Depósitos fluvioglaciais no Peru, Fm Charaña na Bolívia e Fm Chiuchiu no Chile 


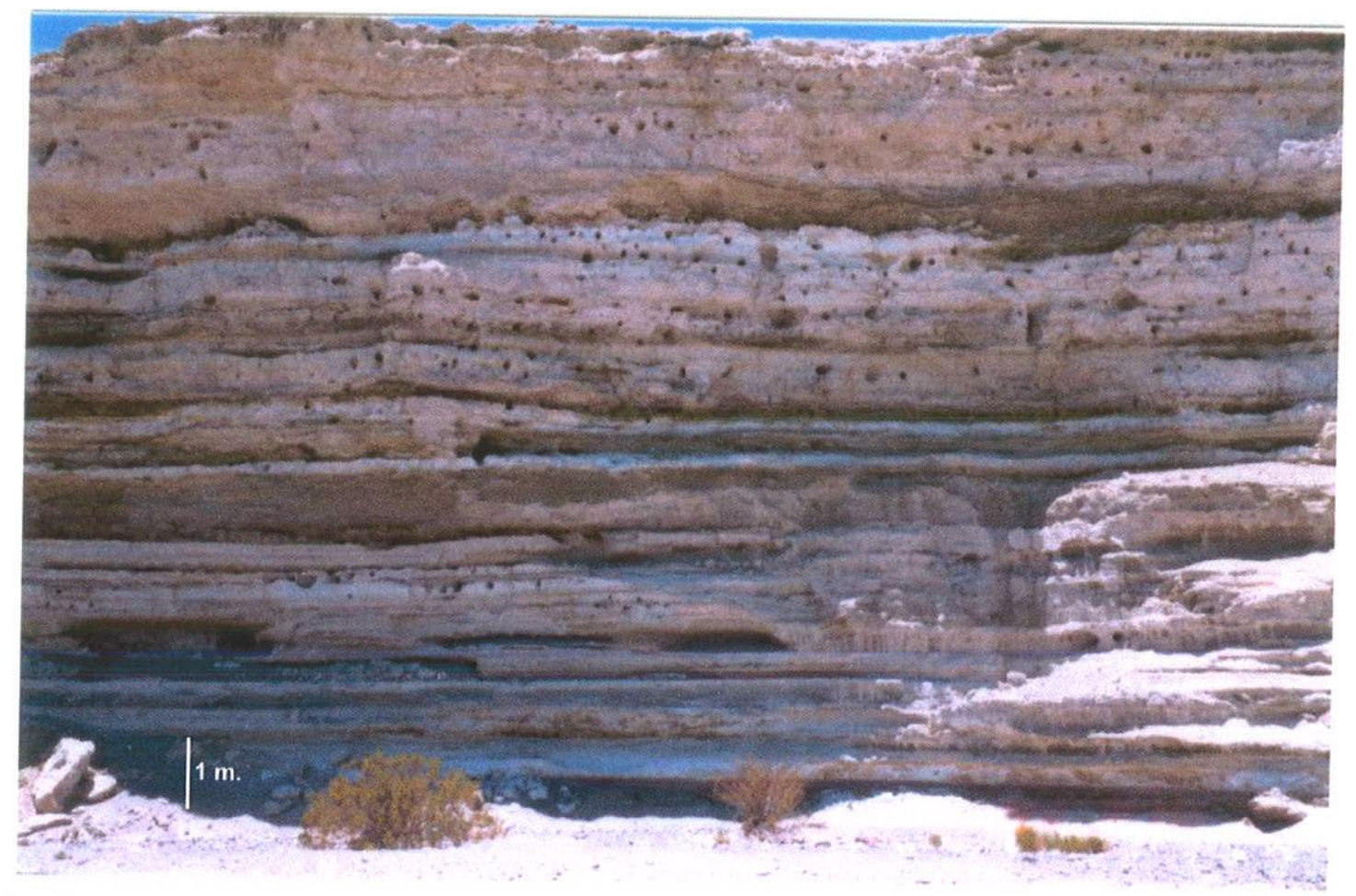

FOTO 8 - Características sedimentares da Formação Charaña na Bolívia

\section{Vulcânico Paucarani.}

Apresenta um afloramento de rochas alteradas próximo à jazida de enxofre Gloria do nevado Paucarani. Nesta localidade MENDIVIL (1965) descreveu a ocorrência desta formação. Litológicamente está constituída por derrames de lava de composição traquitica a traquiandesitica de cor cinza azulada a cinza violácea. Nos afloramentos observa-se depósitos de morainas e pequenas depressões soterrados por derrames de lava. Estes depósitos de lava correspondem a uma das últimas atividades vulcânicas ocorridas em período inferior que 4.000 anos (MEGAR, 1961). Neste panorama de atividade vulcânica encontra-se o vulcão Tacora de $6.000 \mathrm{~m}$ de altitude no Chile.

$\mathrm{Na}$ imagem de satélite o Vulcãnico Paucarani apresenta um resposta espectral em tonalidade cinza escura a marrom. Esta formação, na zona de contato com rochas do grupo Barroso, próxima à jazida de enxofre, apresenta emissão de mananciais de água termal, constituindo-se em ponto de contaminação natural de águas superficiais 


\section{Deposito aluviais e flúvio-aluviais (Q-al)}

Acumulações de sedimentos aluviais e flúvio-aluviais encontram-se distribuídos em diferentes planícies e boçorocas naturais, de regime temporário ou permanente, interligadas por cursos de rios.

Ligados a vale do rio Uchusuma, boçoroca natural Venada e Vila Pucara encontram-se depósitos flúvio-aluviais parcialmente retrabalhados, compostos por uma mistura de seixos, areias, material vulcânico, siltes e argilas transportados durante períodos de intensa precipitação pluvial. Estes depósitos também podem ser observadas no entorno da lagoa Blanca, planícies de Ayro, Charaña Pampa.

Os materiais descritos apresentam uma distribuição espacial caótica, tanto na vertical quanto na horizontal. Em conseqüência sua porosidade e permeabilidade varia em função da ocorrência de cascalhos, areias e argilas. A acumulação do material está controlada por variações periódicas dos fluxos de água, existindo afloramentos com espessuras entre $2 \mathrm{~m}$ a $8 \mathrm{~m}$. De modo geral, constituem meios de boa porosidade que facilita a infiltração de águas de precipitação, facilitando a recarga do aqüifero Capillune.

\subsection{0.- Aspecto estrutural}

O modelo regional da tectônica andina mostra uma grande complexidade estrutural, resultado de episódios da evolução da Cordilheira dos Andes com comportamentos diferentes em distintas latitudes do território peruano. DALMAYRAC et.al (1988), INGEMMET (1993).

No sul do Peru, o desenvolvimento das principais estruturas está associado à evolução da Cordilheira Ocidental dos Andes. Na área de pesquisa as deformações encontram-se bastante evidentes e, em alguns casos, soterradas por materiais recentes. Porém com apoio da imagem de satélite LANDSAT, monocromática (FIGURA 17, P: 68), fotografias aéreas, observações de campo e levantamento geofísico foi possivel interpretá-las os principais lineamentos que são de interesses hidrogeológico. Estas exercem controle no fluxo local ou regional de águas subterrâneas ou no comportamento e relações entre aqüiferos. 


\subsection{1.-- Deformações rúptis}

\section{Falhas}

Na sub-bacia observa-se dois sistemas de falhamento N,NW -S,SE e falhas em direção E,NE-W,SW que correspondem a deformações recentes do Terciario Quaternário (FIGURA 17). O primeiro sistema destaca-se por sua extensão regional e alinhamento conspicuo do arco vulcânico (Cordillera el Barroso). Esta estrutura corresponde a uma linha de falha bem definida, N,NE-S,SW, que favoreceu a formação da estrutura de emissão da cadeia de vulcões dos nevado Barroso e Monja que limita a depressão da sub-bacia. A falha principal é cortada por uma falha transversal de movimentação dextral que segue direção E-W paralela ao alinhamento do rio Uchusuma. Esta falha ocasionou um deslocamento de 7 a 8 $\mathrm{km}$ no alinhamento dos vulcões do Barroso.

Outras falhas menores como $\mathrm{F} 2$, foram identificadas na zona de fronteira peruano - chilena em direção $N 329^{\circ} \mathrm{E}$, seguindo paralela ao alinhamento dos poços PA9,PA-6, PA-12 e PA-13 e boçoroca Vilapucara. Esta estrutura afeta à Formação Maure e Sencca e depósitos flúvioglaciais. Próximo a esta estrutura, em direção oeste, apresentam-se duas falhas menores (F3 e F4)) com uma disposição quase paralela. A falha F3 que segue em direção NW, atravessa a linha de fronteira peruana chilena em direção a lagoa Blanca. A falha $F 4$ apresenta-se próximo ao povoado do Ayro e lagoa Blanca - Peru. Esta falha constitui um meio de drenagem de uma fração das águas da zona do Ayro que alimenta as nascentes dos rios do litoral pacífico, no território chileno.

O segundo sistema de falhamento (F5, F6) apresenta-se com um alinhamento não definido e pouco conspícuo que segue a trajetória do rio Uchusuma. A falha (F6) segue uma direção NE com uma trajetória congruente à boçoroca natural Ancuyo, que nasce na lagoa Blanca, passando pelo local Rosaspata, afetando as formações Sencca e Maure.

\section{Fraturamento}

Nos diferentes afloramentos foram observadas rochas com diversas densidades de fraturamento, fundamentalmente aquelas que afetam os ignimbritos da 
Formação Sencca ou Pérez e derrames de lava do vulcânico Barroso, em ambos casos estão relacionadas a diaclases formadas pelo fenômeno de contração de lava durante o processo de resfriamento.

Quanto aos fraturamentos relacionados à tectônica local ou regional, não foi possivel diferenciá-los, devido ao fato que as seqüências Maure, Sencca e Capillune apresentam-se levemente deformadas, com mergulhos entre $24^{\circ}$ a $35^{\circ}$ SE e SW. Isto evidencia uma geometria de tectônica ductil suave, com dobras amplas e, em alguns lugares, a formação Sencca apresenta-se em posição horizontal (Cerro Vilacollo).

Quanto às observações dos afloramentos do vulcânico Barroso, as lavas de derrames de andesitos porfiríticos e brechas de fluxo que afloram na cadeia de vulcões, apresentam-se com mergutho em direção do declive da montanha. Do ponto de vista hidrogeológico, esta seqüência de derrames estratificados possuem alta permeabilidade primaria e secundaria, constituindo meios transmissores favoráveis para a infiltração e recarga de aqüiferos.

Quanto à geometria da sub-bacia, pode-se definir no sentido de um ordenamento estrutural que definiu a acumulação da seqüência vulcano sedimentar: Maure, Secca, Capillune em episódios diferentes durante o Plioceno. Os eventos relacionados a esta permitiram a acumulação de material até uma espessura 1300 metros no Altiplano Ocidental (KLINCK,et al 1993), porém na sub-bacia apenas foi possivel reconhecer até profundidades de $255 \mathrm{~m}$ por método diretos no poço PA-10 (área1), $200 \mathrm{~m}$ (área 2) e aproximadamente até $300 \mathrm{~m}$ por métodos geofísicos. 
FIGURA 17 - LINHAMENTOS MORFOTECTÔNICOS - ÁREA DE FRONTEIRA PERU, BOLÍVIAE CHILE

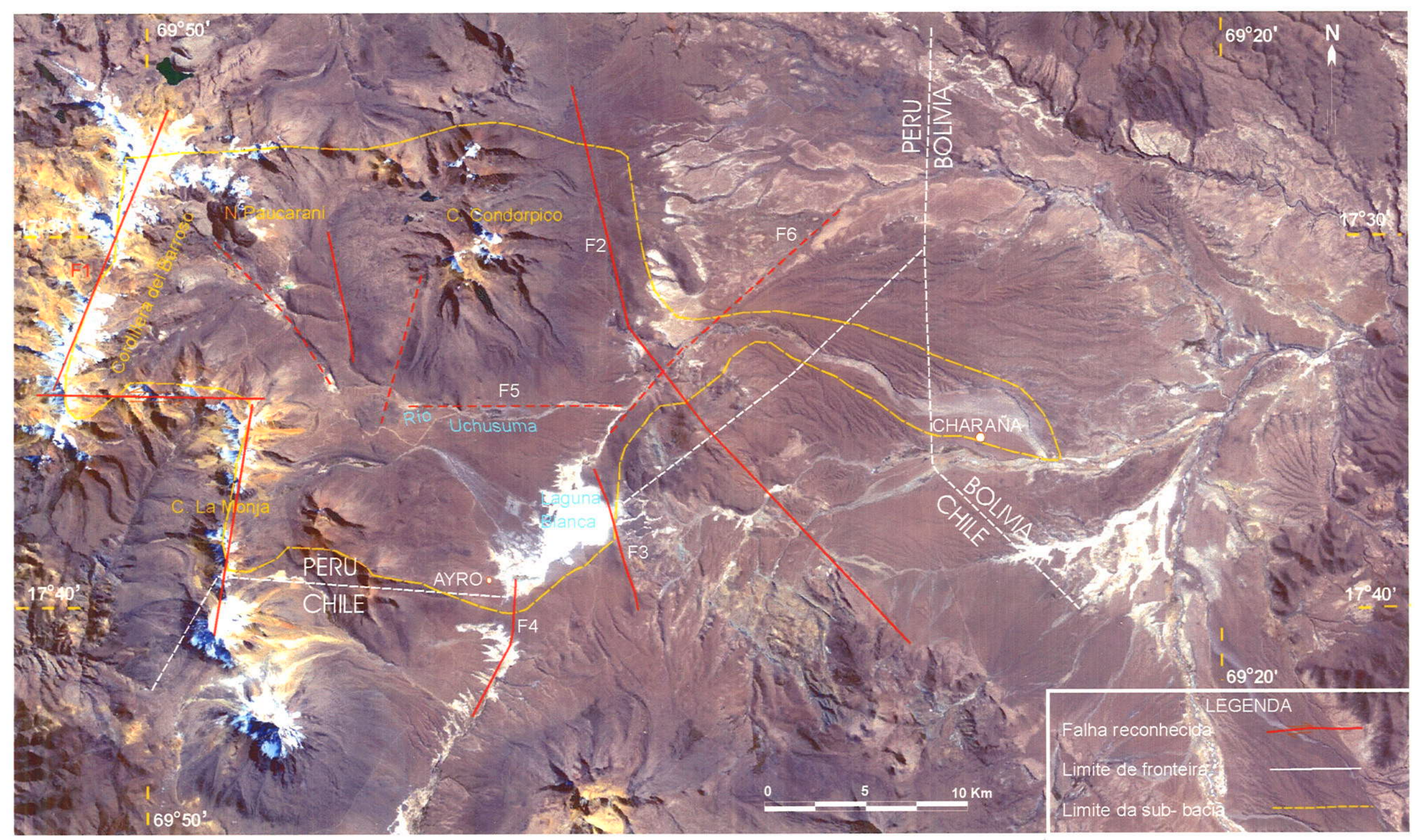

FONTE: Informação trabalhado pelo autor na base de imagem satélite LANDSAT (1995) obtida do Instituto de Recursos Naturais IRD. 


\section{CAPITULO V}

\section{GEOFÍSICA}

$\mathrm{Na}$ pesquisa hidrogeológica, os métodos geofísicos são de amplo uso no conhecimento indireto das características do subsolo, tais como: natureza dos litotipos, extensão, variação lateral e vertical das litofacies, espessura e posicionamento das camadas aqüiferas, características das estruturas que favorecem o armazenamento e circulação das águas subterrâneas.

Dentro dos métodos geofísicos, a técnica da resistividade elétrica constitui uma ferramenta de grande ajuda na caracterização dos aqüiferos como sustenta ASTIER (1975), PARASNIS (1986).

No ano 1984 a instituição "Projeto Especial de Afianzamiento e Ampliación de los Recursos Hidricos de los Departamentos de Tacna e Moquegua" executou trabalhos de levantamento geofísico em diferentes áreas do Altiplano Ocidental, e, dentro destas, nas planícies de Vilacollo e seu entorno, com o objetivo de definir áreas favoráveis para perfuração de poços tubulares profundos destinados a abastecimento de água para o município de Tacna. Do mesmo modo, em 1998, a instituição "Autoridad Binacional del Sistema Hidrico del Lago Titicaca - ALT", realizou trabalhos de sondagem geofísica na zona de Charaña Bolívia, com fins de perfuração de poço para abastecimento do distrito de Charaña da Bolívia.

A informação dos trabalhos das instituições citadas, foram analisadas, selecionadas, reinterpretadas e comparadas com dados de $51 \mathrm{SEVs}$ levantadas durante a pesquisa. A informação obtida foi correlacionada com dados de levantamento geológico, perfis litológicos dos poços perfurados na zona do Ayro Peru (Área 1) e zona de Charaña - Bolívia (Área 2). Desta forma facilitou o conhecimento do modelo sedimentar e hidrogeológico da área pesquisada. A distribuição dos pontos da sondagem considerados mostram-se na FIGURA 18 (p:73) 


\subsection{0.- Base teórica do método de eletrorresistividade}

Está baseado na lei de Ohm, utiliza a propriedade física de resistência que oferecem os corpos a passagem da corrente elétrica, dependendo da natureza e estado físico do corpo considerado. Este fundamento é utilizado na pesquisa hidrogeologica para identificar anomalias relacionadas a tipos de materiais do subsolo (ASTIER, PARASNIS.Op Cit)

Segundo HEILAND apud CANTOS (1974) a resistência de uma rocha impregnada de água ou material não consolidado, depende de três fatores:

- $\quad$ volume relativo dos poros ou de fator de porosidade. É zero quando é compacta; e com aumento da porosidade varia até um;

- forma e distribuição geométrica dos poros, utilizado na geofísica como fator de formação; e

- a resistividade da água, ou grau de mineralização da água, que preenche a porosidade da rocha.

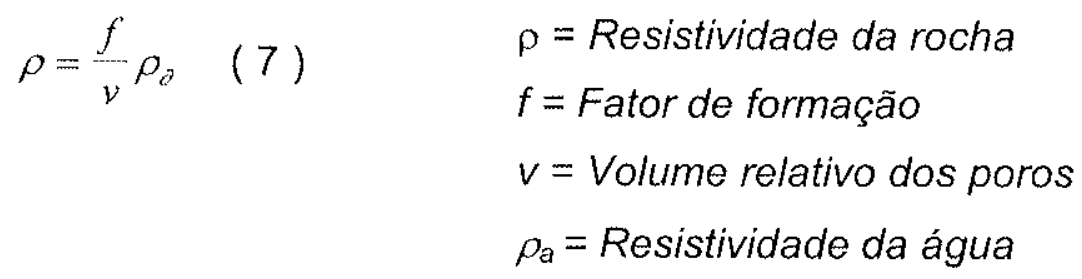

\subsection{0.- Procedimento aplicado}

Utilizou-se um georesistivímetro modelo DDC - 2B de 800 volt, com capacidade de extensão de eletrodos até $1200 \mathrm{~m}$, de fabricação chinesa, para levantamento de dados. A técnica de campo consiste em induzir no subsolo uma corrente contínua de intensidade ( $i$ ), através de um par de eletrodos de emissão (A B). A extensão máxima utilizada para o alinhamento do emissor $A B$, foi de $1000 \mathrm{~m}$, com a finalidade de pesquisar profundidades em torno a 300 metros teoricamente, outro par de eletrodos $(\mathrm{MN})$, chamado de potencial, foi utilizado para medir a diferença de potencial $\Delta \mathrm{V}$ produzido pelo campo elétrico formado. 
Os quatro eletrodos foram dispostos seguindo um arranjo simétrico linear da configuração Schulumberger. Com os valores de diferença de potencial $(\Delta V)$, Intensidade ( 1 ) e distância dos eletrodos, estimou-se a resistividade aparente, aplicando a seguinte equação:

$$
\begin{aligned}
& \Delta v=\text { diferença de potencial }(m V) \\
& \rho_{a}=k \frac{\Delta v}{i} \\
& i=\text { intensidade de corrente }(m A) \\
& \text { (8) } k \text { = constante geométrica que depende da distribuição dos } \\
& \text { eletrodos na superfície em }(m) \\
& \rho_{a}=\text { resistividade do meio em (Ohm.m) }
\end{aligned}
$$

$O$ valor assim quantificado representaria a resistividade verdadeira do meio, se este fosse um espaço homogêneo e isotrópico. Porém, devido à anisotropia e heterogeneidade dos materiais, o valor quantificado é denominado resistividade aparente.

Os valores de resistividade aparente $\rho_{a}$ Ohm.m e distância de medição dos eletrodos $A B / 2$, são representados graficamente em escala logarítmica, para determinar um tipo de curva de resistividade aparente. A interpretação dessas curvas define a resistividade verdadeira das camadas geoétricas e espessura delas no ponto de sondagem. (GARCIA in: CUSTODIO \& LLAMAS, 1996).

\subsection{0.- Levantamento de dados de campo}

Com o intuito de identificar as diferentes formações que compõem o reservatório, executou-se levantamento de SEVs paramétricos na Área 1 nos Poços PA-1, PA3, PA-5, afloramentos da Formação Maure (Coord: 8'064.000 N e 436.000E), e ignimbritos da Formação Sencca ou Pérez nas proximidades do local denominado Cerro Vilacollo (Coord: 8'060.500 N. e 438.000 E). Os dados de resistividade levantados foram correlacionadas com o registro de perfil litológico dos poços perfurados, os quais serviram como elemento de correlação para a interpretação de dados levantados das áreas pesquisadas.

Os trabalhos de correlação e interpretação foram realizados no mapa em escala 1:50.000, onde foram consolidadas informações geofísicas, geológicas e registros de perfil litológico dos poços. A amplitude da informação analisada têm um nivel de representatividade da sub-bacia concordante com os objetivos do estudo. 
As sondagems geofísicas consideradas (FIGURA 18) estão distribuídas do seguinte modo:

Área 1 zona do Ayro - Peru .- Nesta área estão localizadas 69 SEVs, incluídas 33 SEVs, implementadas durante a pesquisa, as quais estão distribuidas com um arranjo NW-SE, com um intervalo de separação de $1 \mathrm{Km}$ aproximadamente. $\mathrm{O}$ espaçamento entre pontos de sondagem varia entre 800 a $1000 \mathrm{~m}$. Além disso, foi implementado um alinhamento de exploração entre o poço PA-1 e PA-13 (NS).

Área 2 zona da Charaña - Bolívia.- Nesta área localizam-se 30 SEVs incluído 13 SEVs da fase de pesquisa, complementadas com registro de exploração direta de um poço de 200 metros de profundidade, perfurado durante a etapa de pesquisa no ano 2000. O conjunto da informação pesquisada contribuiu na caracterização sedimentar do reservatório.

\subsection{0.- Análise de levantamento de dados.}

Os dados de campo foram analisados e interpretados na base teórica de que o subsolo está formado por um número finito de camadas geoelétricas distintas, separadas por planos horizontais, sendo que cada camada é isotrópica e homogênea.

Com base nesta hipótese os dados de campo levantados durante a fase de pesquisa, foram interpretados utilizando-se o programa RESIST software desenvolvido para interpretação de SEVS. O procedimento consiste em harmonizar a curva gerada pelo programa, com a curva de campo do modelo fornecido. Esta se consegue ajustando os parâmetros de resistividade e espessura da sondagem, até obter uma boa aproximação da curva de campo ao modelo, cuja porcentagem de erro deve ser menor que $5 \%$. 


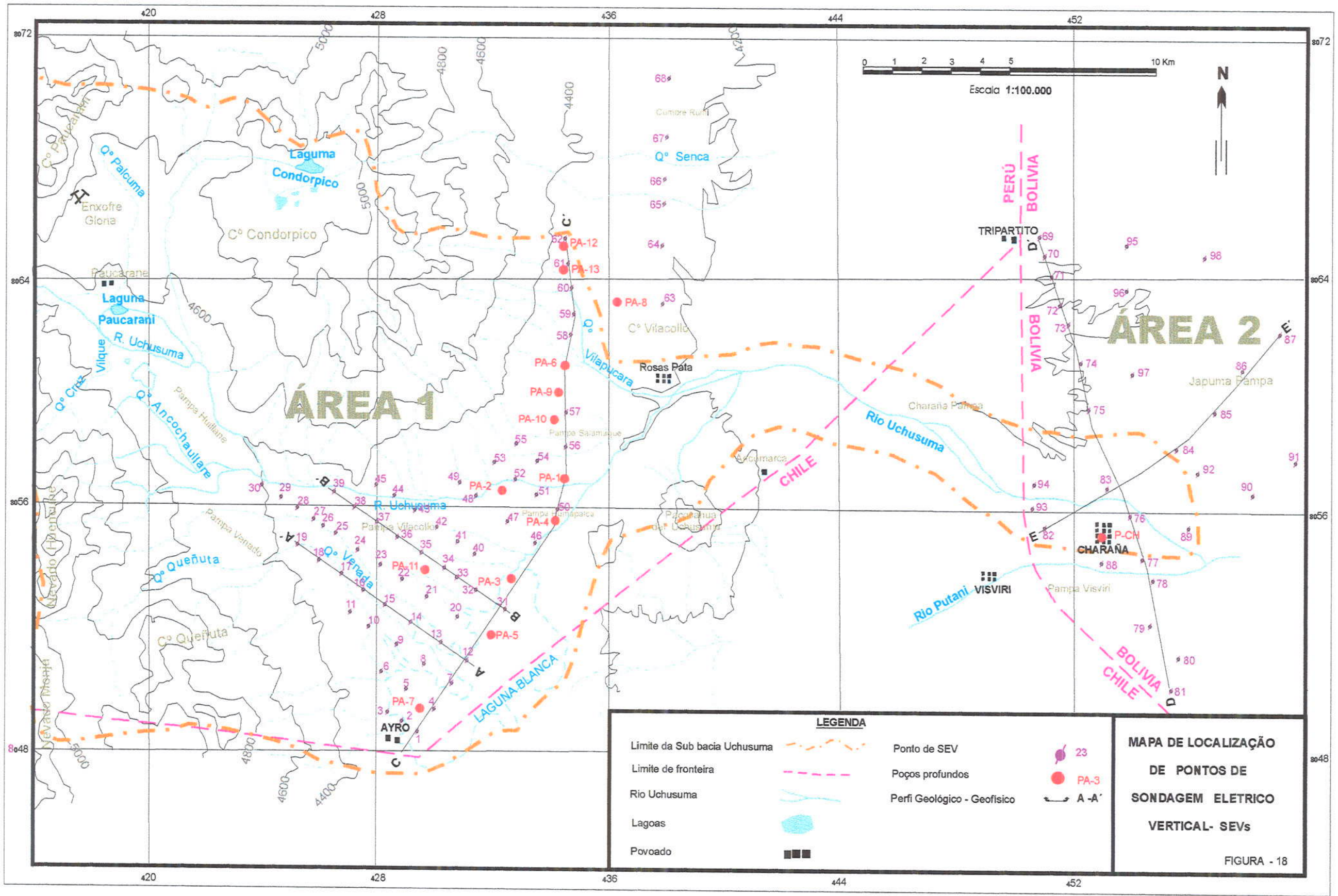


A TABELA 17 e ANEXO $\|$ mostram os resultados da interpretação quantitativa de SEV. Genericamente foi evidenciado três famílias de curvas, que correspondem a modelos físicos de tipos de curva de três e quatro camadas, onde cada um se diferencia por sua morfologia e comportamentos diferentes.

A identificação do tipo de material correspondente a cada uma das camadas geoelétricas, foi determinado por correlação com sondagens paramétricas de pontos de perfuração que dispõem de perfil litológico descritivo registrado pelo geólogo. Esta análise permite de um modo aproximado a identificação do tipo de material e tenta-se excluir interpretações errôneas por atribuir valores altos ou baixos a materiais que não correspondem, embora o nível de confiabilidade esteja limitado pelas características próprias do meio.

Com os dados interpretados, foram elaborados perfis geológico - geofísicos, que ilustram as variações laterais e verticais das diferentes camadas que conformam o aqüífero Capillune e Maure. De modo geral permitem visualizar o modelo do ambiente sedimentar da sub-bacia do rio Uchusuma. Suas características são descritas com ajuda de mapas de contorno de isorresistividades, e mapas de isoespessura das formações pesquisadas.

TABELA 17 - DADOS DE SONDAGEM PARAMÉTRICA PARA CORRELAÇÃO E INTERPRETAÇÃO QUANTITATIVA

\begin{tabular}{|c|c|c|c|c|c|c|c|c|c|c|c|c|}
\hline Núm. & \multicolumn{2}{|c|}{ Camada } & \multicolumn{2}{|c|}{ Camada 1} & \multicolumn{2}{|c|}{ Camada 2} & \multicolumn{2}{|c|}{ Camada 3} & \multicolumn{2}{|c|}{ Camda 4} & \multicolumn{2}{|c|}{ Camada 5} \\
\hline$S E V$ & $h .^{\circ}$ & $\therefore \rho^{\circ}$ & $k 1$ & $\rho 1$ & $\mathrm{H}_{2}$ & $\rho 2$ & h 3 & $\rho 3$ & h4 & $p 4$ & h 5 & $\rho 5$ \\
\hline PA- 1 & 5 & 175 & 24 & 73 & 42 & 263 & & 72 & & & & \\
\hline PA.3 & 5 & 138 & 18 & 95 & 75 & 115 & & 63 & & & & \\
\hline PA-5 & 9 & 43 & 15 & 86 & 34 & 54 & 62 & 33 & & 25 & & \\
\hline Fm. Senca & 3 & 416 & 19 & 116 & 36 & 189 & & 36 & & & & \\
\hline & & 673 & & 226 & & 302 & & & & & & \\
\hline Fm. Maure & 4 & 241 & 48 & 86 & 78 & 69 & & 58 & & & & \\
\hline
\end{tabular}

$\rho$ : Resistividade ohm.m, h:espessura da camada $(m)$

\subsection{1.- Perfis geológicos - geofísicos}

As seções longitudinais e transversais AA', BB', CC', DD', EE' , (FIGURAS 19,20,21., P:77, 78, 79) foram elaboradas a partir do mapa 1:50.000. Estes perfis permitem uma adequada visualização das variações laterais e verticais das diferentes camadas, e expõe a geometria e morfologia do aqüifero em toda sua extensão. 
$\mathrm{Na}$ elaboração do perfil, os dados foram representados utilizando-se uma escala vertical 1:5.000 1:2.500, e nestas podem-se apreciar, de maneira resumida, as diferentes formações que a compõem.

Camada 1.- A zona do Ayro (área 1), está constituída por sedimentos secos acima do nivel da água; este horizonte possui uma espessura média de $3 \mathrm{~m}$, como aparece nos perfil AA', BB', CC' (FIGURAS 19,20) e uma máxima de 10 m (SEV 7 ). As resistividades tomam valores entre 89 ohm.m a 521 ohm.m, que identificam os depósitos fluvioglaciais, eluviais, aluvionais do Quaternário recente, composto por uma mistura de material flúvioglacial: areias, siltes, cascalhos, areias siltosas.

Na zona de Charaña (área 2) a camada 1 (FIGURA 21), apresenta resistividades que variam entre $10 \mathrm{ohm} . \mathrm{m}$ (SEV 80) a $480 \mathrm{ohm}$ (SEV 86). Durante a perfuração do poço de Charaña este horizonte foi encontrado com uma espessura de 30 metros, composto por areias, siltes, cascalhos. Estratigraficamente corresponde a Formação Charaña que eqüivale ao Quaternário Flúvioglacial do Peru.

Camada 2.- , nos perfis $A A^{\prime}, B^{\prime}, C^{\prime} C^{\prime}$ (FIGURAS 19, 20) esta segunda camada na área 1 mostra-se evidente, $\mathrm{e}$ as espessuras variam notavelmente em toda a zona do Ayro. Na área denominada lagoa Blanca (setor Sul Sudoeste do perfil CC' (FIGURA 20) apresenta-se um paleovale soterrado e congruente ao curso do rio que desce da boçoroca Venada. Nesta zona esta camada atinge a máxima espessura de 220 m (SEV 12, PA-5 e PA-7) com resistividades entre 40 ohm.m a 50 ohm.m, constituída por uma intercalação de cascalhos, areias de diferentes granulometrias, siltes e argilas. Neste paleovale destaca-se a presença de uma falha que constitui o limite da encosta do vale. A partir deste ponto, e em direção norte, a espessura da segunda camada diminui para 14 e $24 \mathrm{~m}$ em diferentes pontos com resistividades variando entre $56 \mathrm{ohm} . \mathrm{m}$ a $95 \mathrm{ohm} . \mathrm{m}$. Litologicamente está composta por sedimentos de diferentes granulometrias, variando no sentido vertical e horizontal. Segundo as sondagens paramétricas, as resistividades estão vinculadas a areias, cascalhos arenosos de diferentes granulometrias, intercalados com areias finas e pequenas lâminas de silte ou argilas. Por correlação estratigráfica as resistividades identificam o aqüífero livre da Formação Capillune que foi identificado nos poços: PA - 2, 3, 4, 5 e 7. 
Na Área 2 os valores de resistividades mais freqüentes para este horizonte é de 30 ohm.m (SEV 80) a 126 ohm.m(SEV 93). De modo geral o material relacionado segundo as resistividades corresponde a areias de grão grosso, areias siltosas e cascalhos de granulometría variada. As resistividades identificam - alongamento da Formação Capillune na área boliviana, o mesmo que foi identificado no perfil litológico do poço de Charaña.

Camada 3 - Nos perfis geológicos geofísicos (FIGURAS 19 e 20) da zona do Ayro (área 1) observa-se que, nas profundidades entre 50 a $130 \mathrm{~m}$, apresentam-se umas camadas com resistividades entre 110 ohm.m (SEV 31) a 263 ohm.m (SEV do poço PA-1). Estas resistividades, segundo as sondagens paramétricas, caracterizam os ignimbritos da Formação Sencca. Sua espessura máxima é de 98 m (SEV 36). A geometria desta formação é irregular, apresentando-se erodida ao longo do paleovale da boçoroca Venada.

$\mathrm{Na}$ zona de Charaña (área 2) as resistividades dos diferentes SEVs não permitiram associar a um tipo de rocha, porém durante a perfuração do poço de Charaña foi interceptada uma camada de ignimbritos da Formação Pérez, ou Sencca a uma profundidade de 56 metros com uma espessura de 45 metros e com uma resistividade de 100 ohm.m a 320 ohm.m (dado do perfil elétrico do poço ALT-Ch FIGURA 22, P:80). Tomando esta referência, a terceira camada foi correlacionado com ignimbritos da Formação Pérez, eqüivalente à Formação Sencca do Peru.

Camada 4.- Na zona do Ayro (área 1), em profundidades entre 80 a 100 metros, apresenta uma camada de espessura não definida, com uma geometria e distribuição irregular como mostra-se nos perfis BB'CC' (FIGURA 19 e 20). As resistividades desta camada variam entre 42 ohm;m (SEV 31) a 113 ohm.m.(SEV 58). Correlacionando estes valores com sondagens paramétricas TABELA 17, identifica-se o aqüifero semi-confinado da Formação Maure, cujos valores variam entre 69 ohm.m a 93 ohm.m, litologicamente composto por conglomerados vulcânicos de diferentes granulometrias, arenitos interestratificados com siltitos e argilitos. 


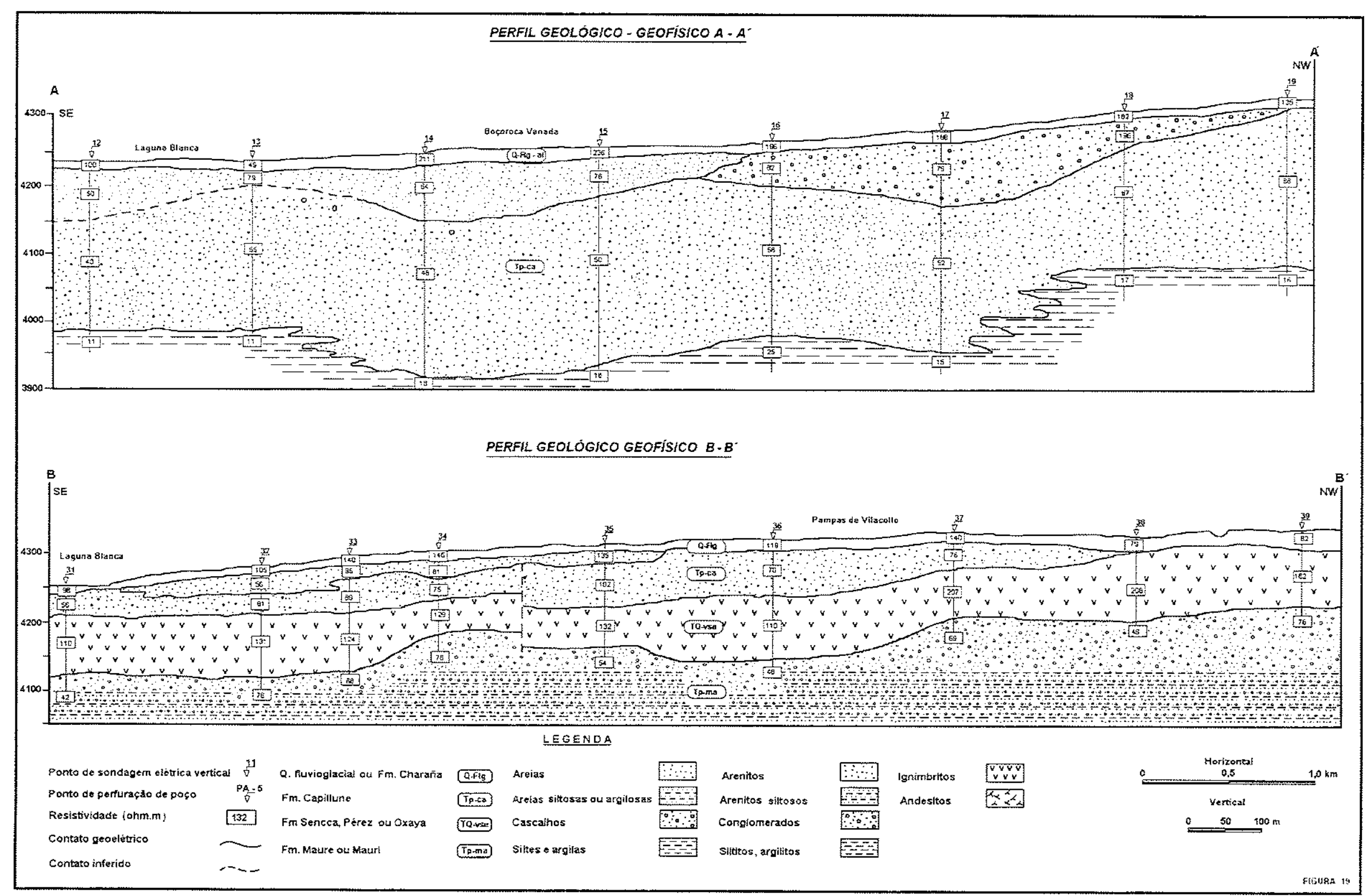




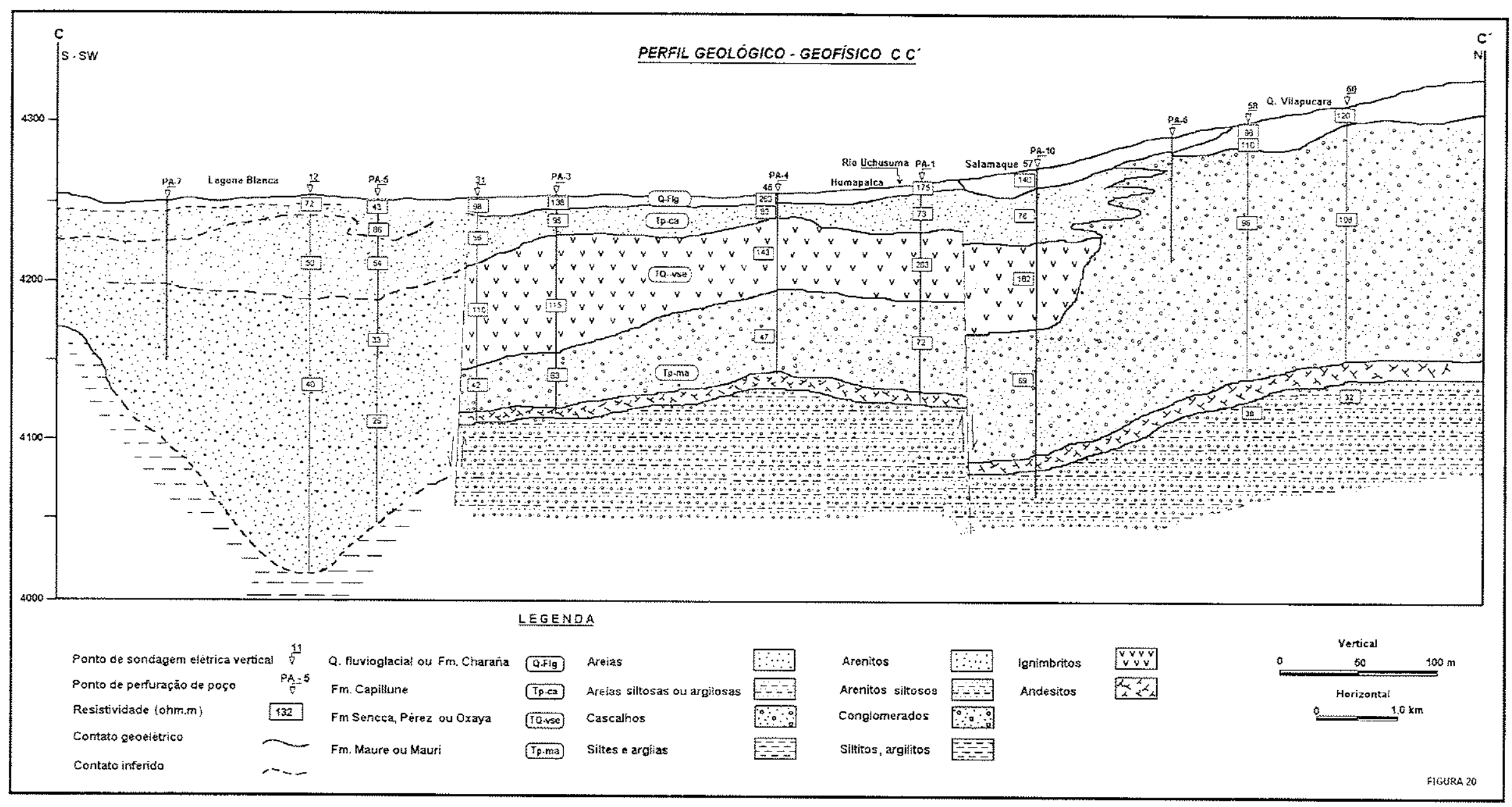




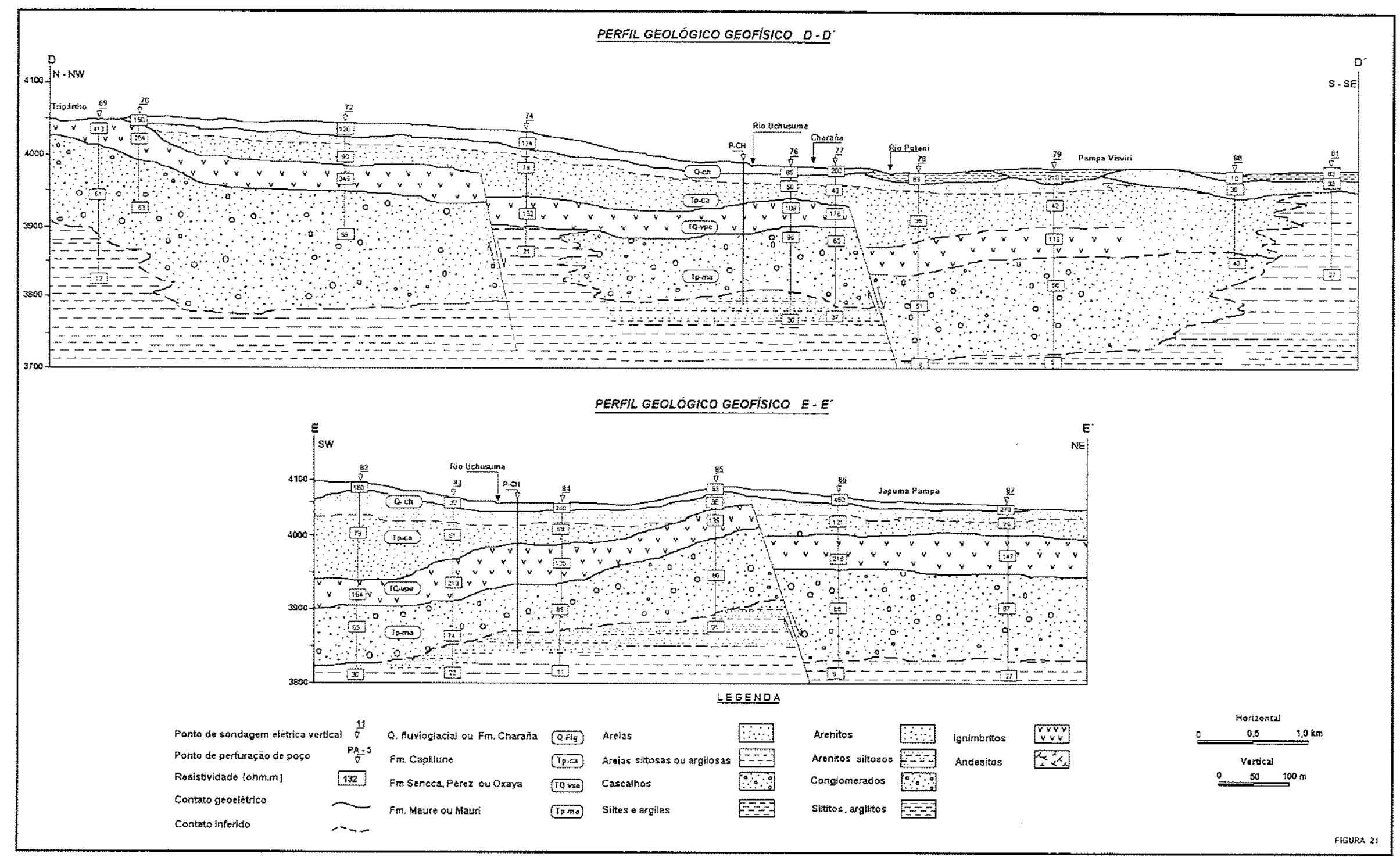


Na zona de Charaña (área 2) as resistividades de 58 ohm.m (SEV 72) a 118 ohm.m (SEV 73) podem ser equiparadas às características sedimentares da Formação Maure, reconhecida na área 1. Durante a perfuração do poço de Charaña foi identificada esta formação a uma profundidade de 91 metros, composta de conglomerados quartzosos, intercalados com arenitos de cor verde oliva e lâminas de siltitos, argilitos de cores verde, cinza esverdeada e cinza chumbo, e argilas. Segundo os dados de perfil elétrico do poço ALT-PCH (FIGURA 22) apresentam uma resistividade média de $35 \mathrm{ohm} . \mathrm{m}$. Em profundidade as resistividades descem a valores menores do que $20 \mathrm{ohm} . \mathrm{m}$, e estão associadas a material argiloso.

FIGURA 22 - PERFIL. ELÉTRICO DO POÇO DE CHARAÑA (ALT-CH) BOLIVIA

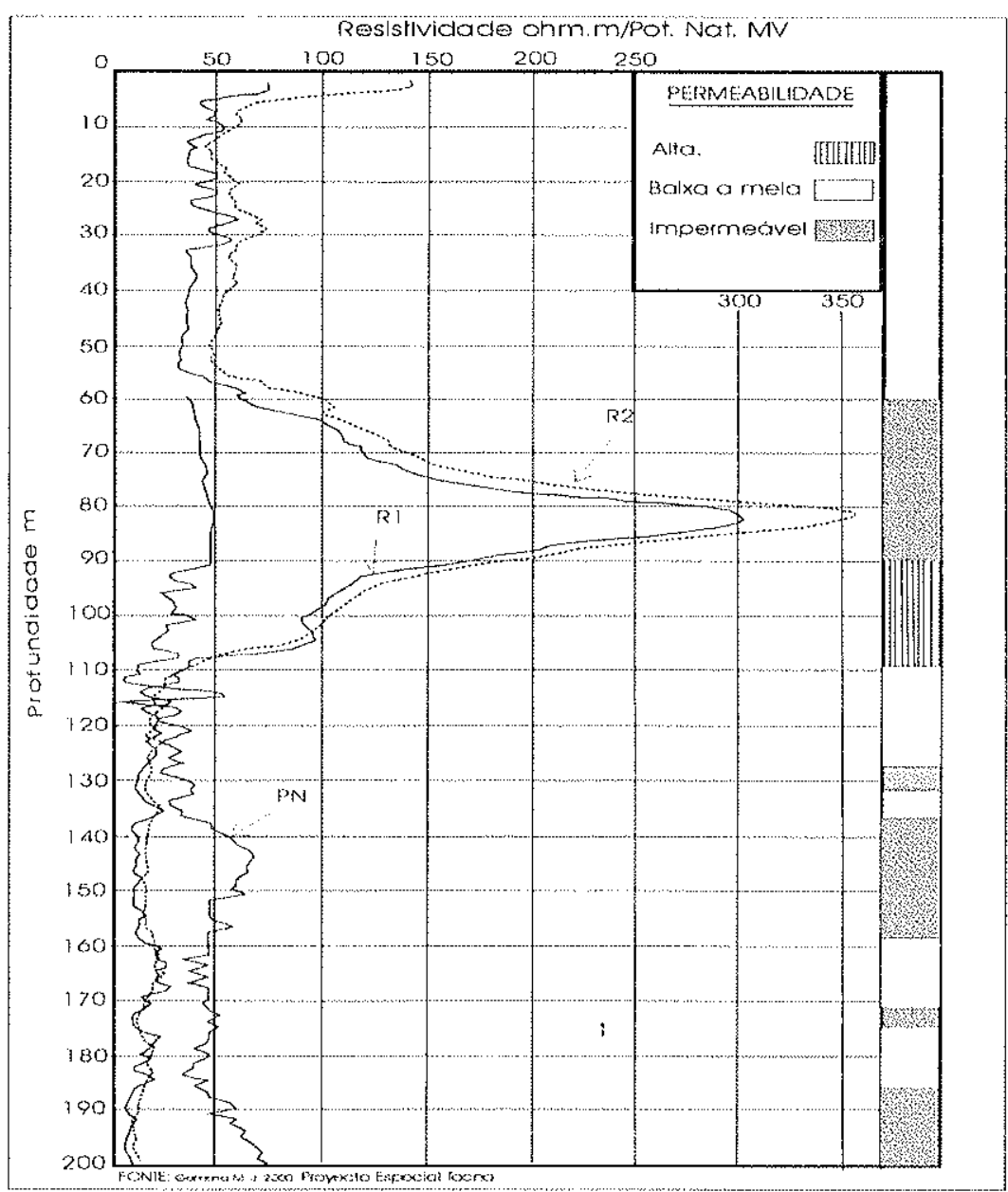




\subsection{2." Mapa de contorno de resistividade verdadeira}

a).- Interpretação de mapas de resistividade para $A B / 2=100 \mathrm{~m}$.

Área 1. De modo geral os mapas elaborados têm por objetivo ampliar e/ou conferir a interpretação descrita nos itens anteriores referentes a natureza dos depósitos e variações laterais dos sedimentos desde a superfície até profundidade aproximada de 50 metros. Na FIGURA 23 (p: 83) observa-se a curva de isorresistividade de $50 \mathrm{ohm} . \mathrm{m}$ contornando o vale da boçoroca Venada (zona NW do lugar denominado Laguna Blanca). Os valores incrementam-se até 150 ohm.m em direção norte, na área que corresponde a planície de Vilacollo. Em forma expandida estende-se em direção norte através da planície Salamaque e zona compreendida da boçoroca Vilapucara.

Analisando os perfis $\mathrm{AA}^{\prime}, \mathrm{BB}^{\prime}, \mathrm{CC}^{\prime}$,(FIGURAS 19, 20, p:77,78) observa-se que os valores entre 48 a 100 ohm.m estão relacionados a depósitos da Formação Capillune, composta por uma intercalação de areias, cascalhos arenosos de granulometria variada, lâminas e lentes de siltes e argilas, observados no perfil CC'(FIGURA 20).

Na zona de Charaña (área 2) observa-se uma distribuição de curvas de contorno mais homogênea, incrementando seus valores de $50 \mathrm{ohm} . \mathrm{m}$ a $250 \mathrm{ohm} . \mathrm{m}$ de sul a norte, desde áreas adjacentes ao povoado de Charaña em direção ao local de Tripartito, ponto de encontro dos limites de fronteira do Peru, Bolivia e Chile (FIGURA 23, p:83). Nesta configuração as curvas de contorno menores que 100 ohm.m definem em parte, a Formação Charaña e Formação Capillune, cujo contato estratigráfico não é nítido. Muda de modo gradativo, ou progressivo, entre estas duas formações, e por outra parte, o contorno das curvas maiores que 100 ohm.m, mostra a distribuição dos ignimbritos da Formação Pérez ou Sencca presente no subsolo. A tendência das curvas é congruente com as características da distribuição dos afloramentos dos ignimbritos em superficie, mostrando-se evidente na imagem de satélite e mapa geológico (FIGURAS.14 e 15., p: 53, 54). 
b).- Interpretação de mapas de resistividade para $A B / 2=300 \mathrm{~m}$.

Área 1.- Na FIGURA 24 (p: 84), a morfologia das curvas mostram uma característica similar ao mapa $A B / 2100 \mathrm{~m}$. Neste mapa distinge-se claramente as curvas de resistividade de 50 ohm.m que contornam a zona de laguna Blanca, alongando-se através do vale Venada, incrementando suas resistividades a $150 \mathrm{ohm} . \mathrm{m}$ em direção norte (zona de planícies de Vilacollo e trajetória do rio Uchusuma). Segundo a interpretação dos perfis geofísicos e sondagens paramétricas, as resistividades entre 110 a $302 \mathrm{ohm} . \mathrm{m}$, ou maiores a esta, definem os ignimbritos da Formação Sencca. Esta formação, na zona do Ayro, apresenta-se com uma distribuição irregular em diferentes profundidades entre 50 e 130 metros, afetada por uma tectónica rúptil.

De outra parte, o contorno das curva menores que $100 \mathrm{ohm} . \mathrm{m}$ estão relacionados a depósitos da Formação Maure, que está presente a uma profundidade entre 100 e 150 metros

Na zona de Charaña (área 2) a morfologia da curva mostra-se mais homogênea. $\mathrm{Na} z o n a$ central distingue-se uma área delimitada pela curva de $100 \mathrm{ohm} . \mathrm{m}$, e suas caracteristicas de distribuição identifica em parte, os ignimbritos da Formação Pérez da Bolívia e, lateralmente os valores menores do que $100 \mathrm{ohm} . \mathrm{m}$ estão vinculados a Formação Mauri da Bolívia.

\subsection{3.- Mapa Isoespessura da Formação Sencca ou Peréz. (FIGURA 25, p:85).}

Este mapa foi elaborado tomando dados de espessuras de uma das camadas geoelétricas bem definida na área pesquisada. Neste caso, o objetivo foi definir a geometria e morfologia da camada impermeável dos ignimbritos da Formação Sencca, ou Pérez, que separa o aqüifero livre da Formação Capillune e em profundidade o aqüífero semi-confinado da Formação Maure. Na zona do Ayro (área 1), a distribuição das curvas de contorno exibe a variação das espessuras em diferentes locais, desde $40 \mathrm{~m}$ a $100 \mathrm{~m}$ em direção norte. Na zona de Charaña a espessura desta formação varia lateralmente. $A$ interpretação correspondente é concordante, comparada com os perfis elaborados e registros estratigráficos de poços profundos. 


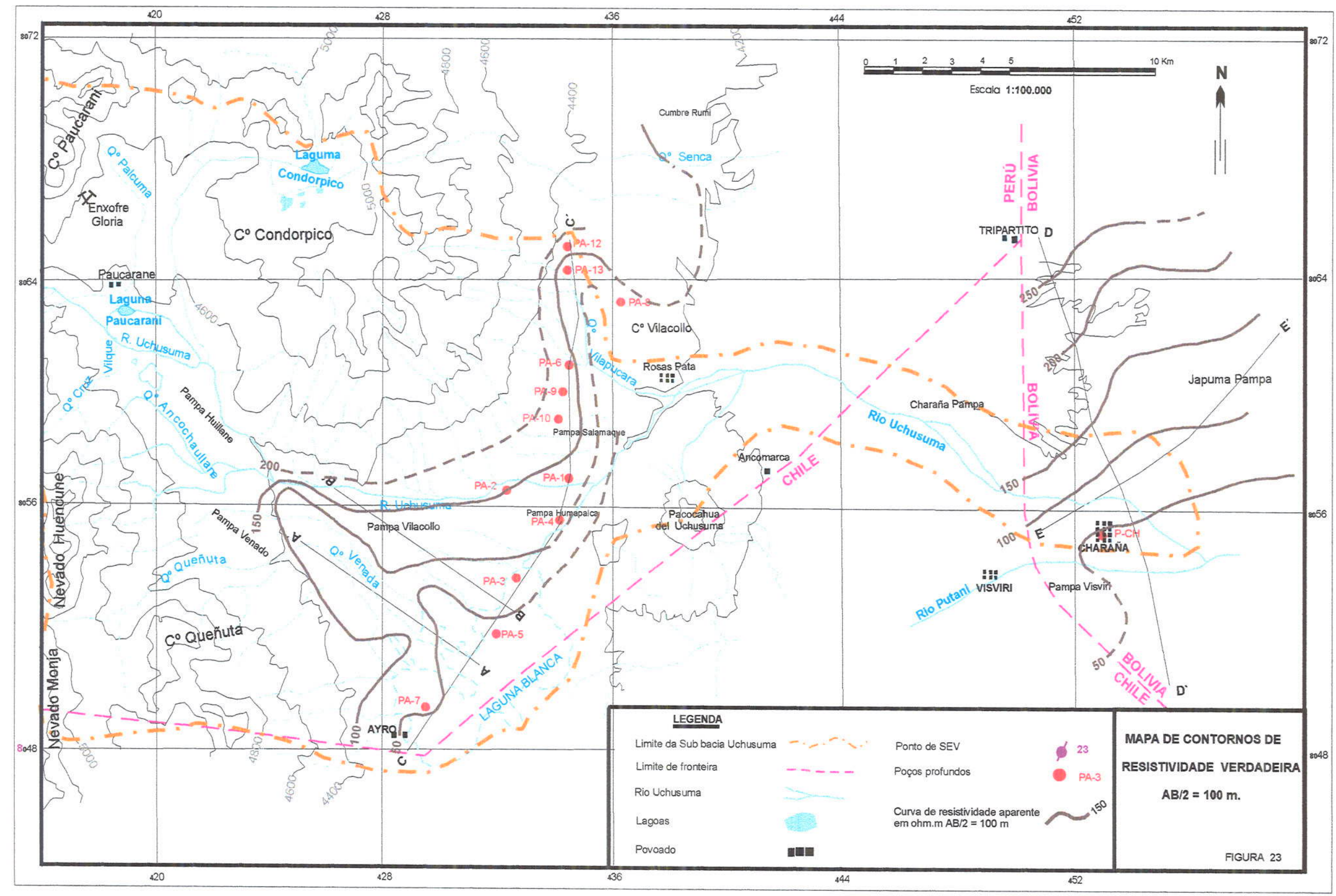




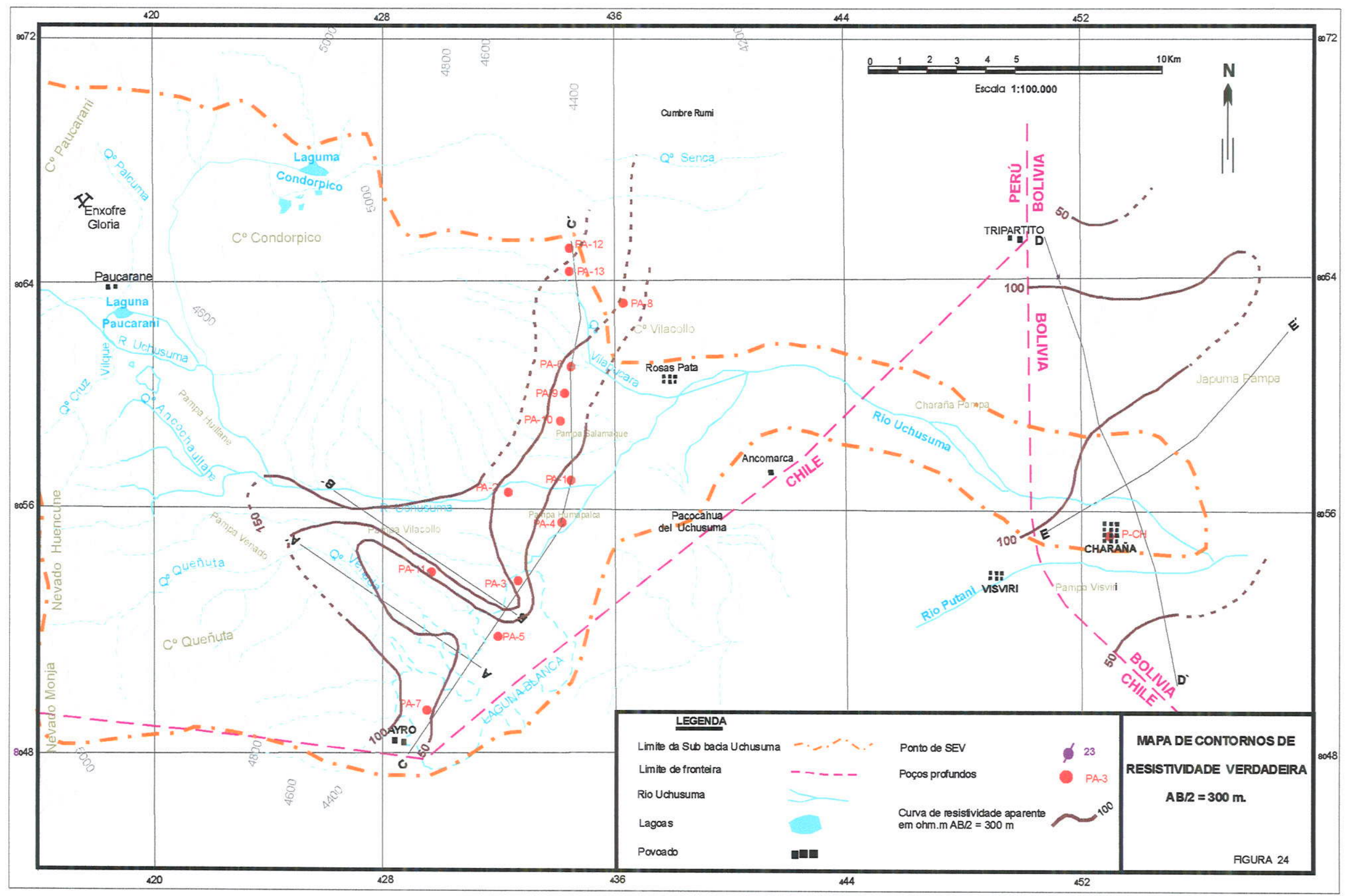




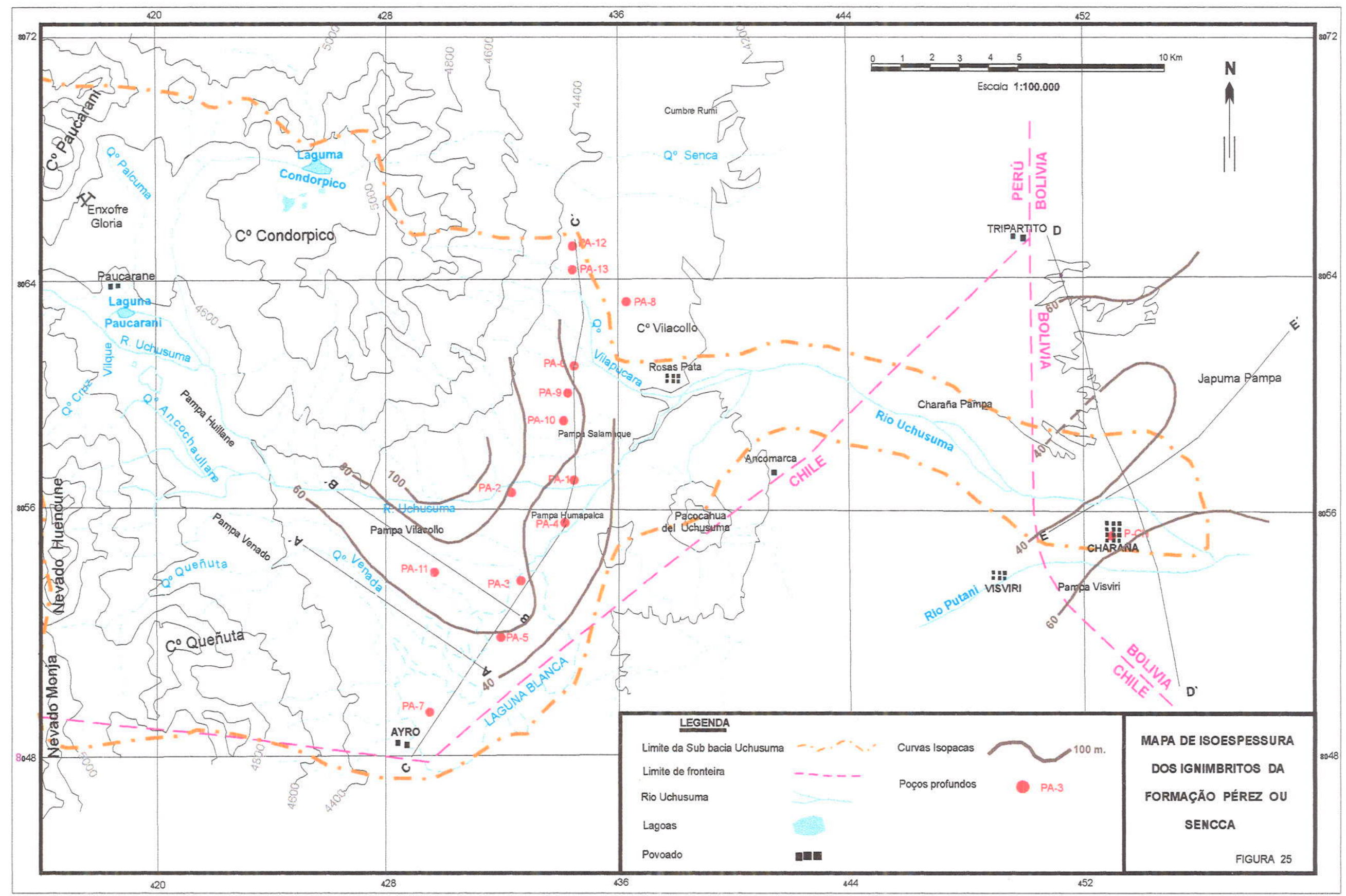




\section{CAPITULO VI}

\section{HIDROGEOLOGIA}

\subsection{0.- Sistema hídrico Uchusuma}

O sistema de drenagem da sub-bacia está composto por um rio principal denominado Uchusuma e numerosos cursos de regimes permanentes que abastecem a vazão de fluxo deste rio. Entre os principais tributários destacam-se aqueles que nascem de lagos glaciais Tiapujo e Paucarani, e descem através das boçorocas naturais. Outros tributários nascem em vales glaciais como a boçoroca Queñuta ou vales estruturais como o Vilapura (FIGURA 12, p:42)

Observa-se que, no maior período do ano, o rio Uchusuma é alimentado por águas que procedem do degelo de glaciais da Cordilherira el Barroso, lagos glaciais, mananciais, e aportes que recebem na temporada de precipitação dentro da área de $624 \mathrm{Km}^{2}$ que abrange a sub-bacia.

O rio Uchusuma percorre uma distância aproximada de $48 \mathrm{~km}$ desde suas nascentes, no território peruano, atravessando pequena área do território chileno para logo ingressar no território boliviano, até sua confluência com o rios Putani, Caquena, Kaño, para desaguar no rio Mauri e dai no rio Desaguadero, e finalmente no lago Poopó. (FIGURA 2, p:23)

A vazão de fluxo do rio Uchusuma é controlada na estação limnimétrica "Bocatoma Uchusuma - Ayro Nuevo" (cota $4280 \mathrm{~m}$ ) antes do ponto de captação ou derivação das águas para o litoral pacífico através do canal Uchusuma. A estação de medição é controlada pelo Proyecto Especial Tacna e Servicio Nacional de Meteorologia e Hidrologia PET-SENANMHI desde 1963.

A vazão média anual do rio Uchusuma para o periodo 1963 - 1997 (34 anos) é de $0,755 \mathrm{~m}^{3} / \mathrm{s}$ (ANEXO $\mathrm{V}$ ), equivalente a uma descarga de $23,8 \times 10^{6} \mathrm{~m}^{3} /$ ano. A máxima descarga foi registrada em $1988\left(1,160 \mathrm{~m}^{3} / \mathrm{s}\right)$ com um volume de descarga de 36,6 milhões de metros cúbicos. Dados de descarga do período 2002 a 2003 apresentam-se na TABELA 18. No período 1963-1997 a descarga mais baixa fol registrada em $1966\left(0,541 \mathrm{~m}^{3} / \mathrm{s}\right)$. As vazões mensais mais altas correspondem aos meses de janeiro a abril, a temporada de precipitação. 
Em épocas de estiagem o volume de água derivada para o Município de Tacna através do canal de adução Uchusuma - Quebrada Vilavilani, atinge a uma vazão de $0,7 \mathrm{~m}^{3} / \mathrm{s}$. Segundo informação de ALT (1996), o volume de água captada da bacia Uchusuma pelo Município de Tacna, atinge:

- Vazão regulada na barragem Paucarani

$=1191,60 \mathrm{~m}^{3} / \mathrm{h}$.

- Aportes do rio Venado

$=180,00 \mathrm{~m}^{3} / \mathrm{h}$

- Aportes de manancial Ancochaullane

$=18,00 \mathrm{~m}^{3} / \mathrm{h}$

- Aportes de água superficial canal Patapujo

$=252,00 \mathrm{~m}^{3} / \mathrm{h}$

- Água subterrânea

$=\underline{1375,20 \mathrm{~m}^{3} / \mathrm{h}}$

TOTAL

$=3016,80 \mathrm{~m}^{3} / \mathrm{h}$

FONTE: Autoridad Binacional del lago Titicaca (1996)

TABELA 18 - DESCARGAS DIÁRIAS (m³/s) DO RIO UCHUSUMA PERIODO 2002 - 2003

\begin{tabular}{|c|c|c|c|c|c|c|c|c|c|c|c|c|}
\hline \multicolumn{13}{|c|}{ Controle de vazäo do rio Uchusuma estação: Piedras Blanca } \\
\hline \multirow{2}{*}{ DIA/Mês } & \multicolumn{5}{|c|}{2002} & \multicolumn{7}{|c|}{2003} \\
\hline & Ago & Set & Out. & Nov. & Dez. & Jan & Fev & Mar. & Abr. & Maio & Jun & Jul \\
\hline MÉDIA. $\mathrm{m}^{3} / \mathrm{s}$ & 1,6 & 1,6 & 1,5 & 1.5 & 1,3 & 1,3 & 1,1 & 1,2 & 0,9 & 1,2 & 1,0 & 0,9 \\
\hline Vazäo MMC/dia & 0,14 & 0,14 & 0,13 & 0,13 & 0,11 & 0,11 & 0,09 & 0,10 & 0,07 & 0,10 & 0,08 & 0,7 \\
\hline MASSA MMC & 4,2 & 4,3 & 4,1 & 3,9 & 3,4 & 3,4 & 2,8 & 3,3 & 2,4 & 3,2 & 2,5 & 2,4 \\
\hline
\end{tabular}

\subsection{0.- Cadastramento de fontes de água}

Cadastrou-se diferentes fontes de água como nascentes, lagoas e poços profundos, cujos dados foram confrontados com as informações recopiladas de diferentes instituições do Peru e Bolívia. Além dos poços profundos, na área existem numerosos poços cacimba construidos rusticamente de profundidades que não ultrapassam os oito metros, e são de ampla utilização pela população rural para suprir suas necessidades de uso doméstico e pecuário. Estas construções não foram inventariadas, porquanto não contribuem aos propósitos da pesquisa por absoluta falta de condições operacionais. Para trabalho de cadastramento e localização das obras de captação foi utilizado mapa topográfico em escala 1:50.000. 
Tratando de manter a representatividade do local onde ocorrem, as fontes de água foram codificadas seguindo o número de cadastro estabelecido pelo Proyecto Especial Tacna Peru.

\subsection{1.- Cadastramento de poços}

Foram inventariados vinte e nove poços de captação existentes na área de pesquisa e confrontados com as informações compiladas dos arquivos das instituições do Peru e da Bolívia. A localização das obras de captação apresentase na FlGURA 26 ( $p$ : 90). As características técnicas construtivas, como profundidade, revestimento, diâmetro de revestimento, tipo de filtro, estão detalhadas na TABELA 19

\subsection{2.- Cadastramento de nascentes}

\section{a).- Nascentes de regime de fluxo temporário}

De modo geral, estas encontram-se aflorando entre as cotas de $4600 \mathrm{~m}$ e 4900 $\mathrm{m}$, produto da circulação subsuperficial de águas infiltradas de precipitações pluviais e descongelamento de neves. Na temporada de chuva incrementam consideravelmente as vazões e diminuem progressivamente em temporadas de estiagem até sumir em muitos casos. No entorno dos cerros Paucarani foram cadastrados 5 afloramentos de mananciais, embora estes não sejam de interesse hidrogeológico, porém contribuem no sistema de fluxo superficial de água após a época de precipitações.

\section{b).- Nascentes de regime de fluxo permanente}

Na cota entre 4200 e $4700 \mathrm{~m}$ apresentam-se nascentes de regime permanente, geralmente relacionadas a fluxos regionais que emergem no contato entre rochas do Grupo Barroso (Vulcânico Chila) e Formação Capillune, embora o contato entre estas duas unidades esteja soterrado por depósitos fluvioglaciais.

As vazões dos diferentes mananciais cadastrados variam em diferentes épocas do ano, tendo-se determinado entre $18 \mathrm{~L} / \mathrm{s}$ a $34 \mathrm{~L} / \mathrm{s}$ em temporadas de estiagem. Os detalhes dos mananciais cadastrados apresentam-se na TABELA 20 


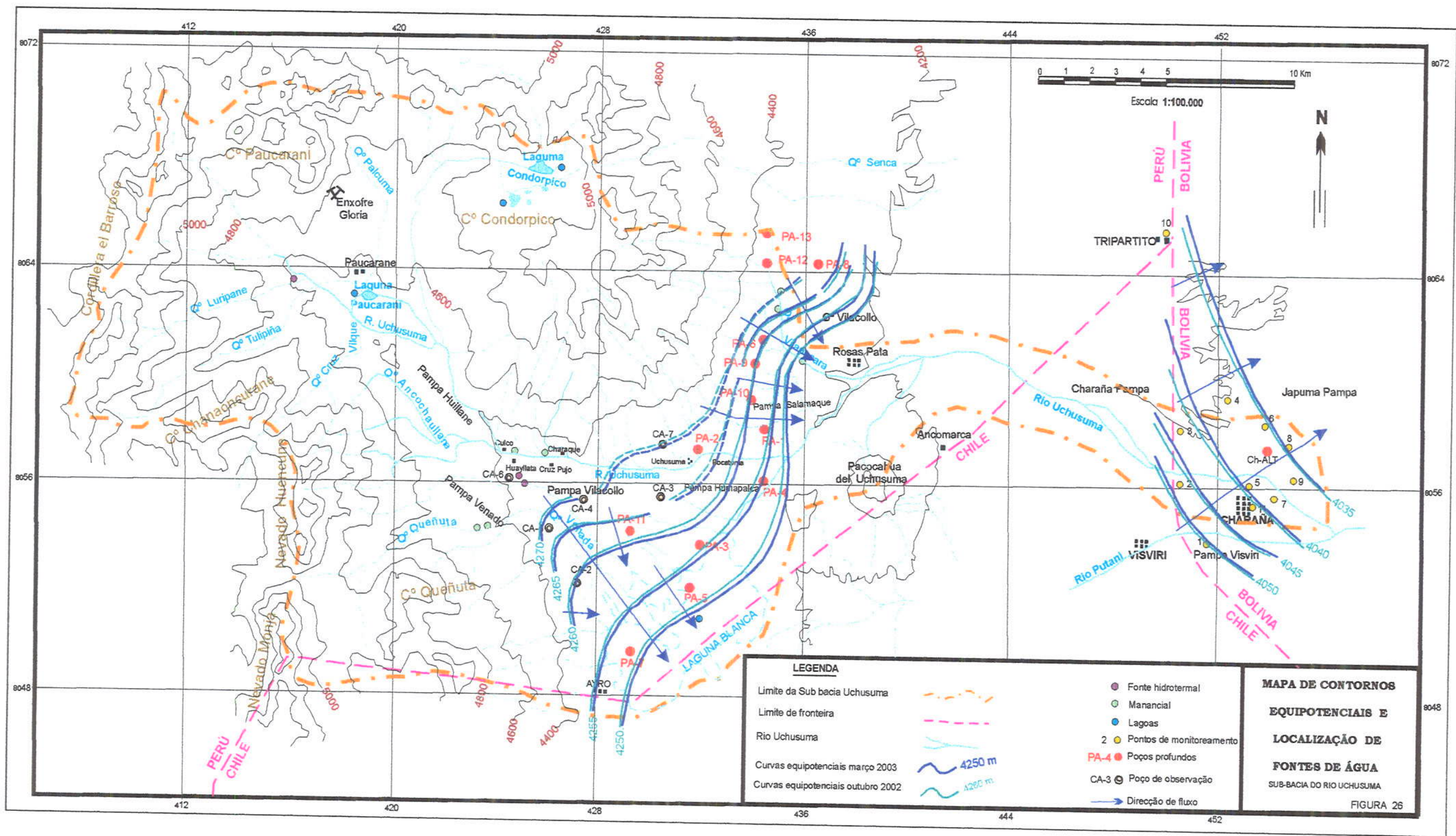


TABELA 19 - CADASTRAMENTO DE POCOS TUBULARES

\begin{tabular}{|c|c|c|c|c|c|c|c|c|c|c|c|c|c|}
\hline \multirow{3}{*}{$\begin{array}{c}\text { Número } \\
\text { Poço }\end{array}$} & \multicolumn{4}{|c|}{ Localizaçäo } & \multirow{3}{*}{$\begin{array}{l}\text { Cota } \\
(\mathrm{m})\end{array}$} & \multicolumn{8}{|c|}{ Dados de mediçāo } \\
\hline & \multirow{2}{*}{ Localidade } & \multirow{2}{*}{ Pro./Pais } & \multicolumn{2}{|c|}{ Coordenadas UTM } & & \multirow{2}{*}{$\begin{array}{l}\text { Prof. Perf. } \\
\qquad(\mathrm{m})\end{array}$} & \multirow{2}{*}{$\begin{array}{l}\text { Prof. } \\
\text { Entub. } \\
\text { (m) }\end{array}$} & \multirow{2}{*}{$\begin{array}{l}\text { Q Entub. } \\
\text { Pulg }\end{array}$} & \multicolumn{2}{|c|}{ Comprimento de Tub } & \multirow{2}{*}{$\begin{array}{c}\text { N.E } \\
\mathrm{m}\end{array}$} & \multirow{2}{*}{$\begin{array}{l}\text { Vazão } Q \\
(\mathrm{~m} 3 / \mathrm{h})\end{array}$} & \multirow[b]{2}{*}{ Observaçöes } \\
\hline & & & Lat & Long. & & & & & $\begin{array}{c}\text { Revestimento } \\
\text { (m) }\end{array}$ & $\begin{array}{l}\text { Filtro. } \\
(m)\end{array}$ & & & \\
\hline PA-1 & Ayro & Tacna-Peru & 8057,56 & 434.27 & 4261,91 & 117 & 105 & 18 & 23 & 82 & & 183,6 & Poço em produçãa atual \\
\hline PCA-1A & Ayro & Tacna-Peru & 8057,57 & 434,28 & 4261,95 & 98 & & 4 & & & 26,20 & & \\
\hline PA-2 & Ayro & Tacna - Peru & 8056,62 & 432,24 & 4259,50 & 150 & 150 & 18 & 12 & 138 & & 111,6 & Poço em produção atual \\
\hline PCA-2A & Ayro & Tacna-Pery & 8056,61 & 432,23 & 4260,00 & 21 & & 15 & & & 7,31 & & \\
\hline PA-3 & Ayro & Tacna- Peru & 8053,80 & 432,10 & 4254,04 & 120 & 119 & 18 & 2 & 117 & & 270,0 & Poço em produção atual \\
\hline PCA-3A & Ayro & Tacna-Peru & 8054,15 & 432,30 & 4256,12 & 25 & & 15 & & & 5,11 & & \\
\hline PA-4 & Ayro & Tacna- Peru & 8055,80 & 434,15 & 4255,58 & 100 & 99 & 18 & 9 & 90 & & 201,6 & Poço em produção atual \\
\hline PCA $4 A$ & Ayro & Tacna - Peru & 8055,81 & 434,14 & 4256,49 & 92,5 & & 15 & & & 16,42 & & \\
\hline PCA-4B & Ayro & Tacna - Peru & 8055,60 & 433,90 & 4261,13 & 75 & & 4 & & & 21,05 & & \\
\hline PA-5 & Ayro & Tacna - Peru & 8051,75 & 431,45 & 4252,19 & 190 & 90 & 21 & 0 & 90 & Jorrante & $216.6^{*}$ & Poço abandonado \\
\hline PCA-5A & Ayro & Tacna - Peru & 8051,80 & 431,40 & 4253,28 & & & & & & 0,14 & & \\
\hline PA-6 & Ayro & Tacna- Peru & 8060,79 & 434,42 & 4263,71 & 66 & 64 & 21 & 5 & 59 & 0,18 & 410.4 & Poço jorrante \\
\hline PCA-6A & Ayro & Tacna-Peru & 8061,00 & 434,35 & 4267,59 & 93,80 & & 4 & & & 2,11 & & \\
\hline PA-7 & Ayro & Tacn a - Peru & 8049,78 & 429,55 & 4251,05 & 102 & 102 & 18 & 7 & 97 & jorrante & $198,0^{*}$ & Poço abandonado \\
\hline PCA-7A & Ayro & Tacna - Peru & 8049,85 & 429,55 & 4247,71 & 28 & & 4 & & & 0,18 & & \\
\hline PA-8 & Ayro & Tacna - Peru & 8063,14 & 436,21 & & & & & & & & & Poço abandonado \\
\hline PA-9 & Ayro & Tacna- Peru & 8060,28 & 434,63 & 4251,77 & 140 & 133 & 18 & $\infty$ & 133 & 14,19 & 129,6 & Poço em produçäo atual \\
\hline$P A-10$ & Ayro & Tacna - Peru & 8059,07 & 434,37 & 4255,14 & 255 & 213 & 21 & 78 & 135 & 17,68 & $183,6^{*}$ & Poço de reserva \\
\hline PA 11 & Ayro & Tacna - Perú & & & & & & & & & 31,32 & $144,0^{*}$ & Poço abandonado \\
\hline PA-12 & Ayro & Tacna - Peru & 8064,06 & 434,48 & 4337,26 & & & & & & 5.01 & $295,2^{*}$ & Poço de reserva \\
\hline PA-13 & Ayro & Tacna - Peru & 8064,73 & 434,61 & 4361,90 & & & & & & 12,54 & $154,8^{\star}$ & Poço de reserva \\
\hline $\mathrm{CA}-2$ & Ayro & Tacna - Peru & 8051,90 & 427,10 & 4230,10 & & & & & & 19,93 & & \\
\hline $\mathrm{CA}-3$ & Ayro & Tacna - Peru & 8054,30 & 430,10 & 4285,04 & & & & & & 22,19 & & \\
\hline $\mathrm{CA}-4$ & Ayro & Tacna - Peru & 8055,20 & 425,90 & 4233,23 & & & & & & 42,06 & & \\
\hline$C A-5$ & Ayro & Tacna - Peru & 8054,90 & 424,90 & 4428,96 & & & & & & & & \\
\hline $\mathrm{CA}-6$ & Ayro & Tacna - Peru & 8057,40 & 423,65 & 4369,81 & & & & & & 14,60 & & \\
\hline CA-7 & Ayro & Tacna - Peru & 8057,25 & 430,10 & 4294,38 & & & & & & 14,59 & & \\
\hline
\end{tabular}




\begin{tabular}{|c|c|c|c|c|c|c|c|c|c|c|c|c|c|}
\hline \multirow{3}{*}{$\begin{array}{c}\text { Número } \\
\text { Poço }\end{array}$} & \multicolumn{4}{|c|}{ Localização } & \multirow{3}{*}{$\begin{array}{l}\text { Cota } \\
\text { (m) }\end{array}$} & \multicolumn{8}{|c|}{ Dados de medição } \\
\hline & \multirow{2}{*}{ Localidade } & \multirow{2}{*}{ Pro./Pais } & \multicolumn{2}{|c|}{ Coordenadas UTM } & & \multirow{2}{*}{$\begin{array}{c}\text { Prof. } \\
\text { Perf.(m) }\end{array}$} & \multirow{2}{*}{$\begin{array}{l}\text { Prof. Entub } \\
\text { (m) }\end{array}$} & \multirow{2}{*}{$\begin{array}{l}\text { Q Entub. } \\
\text { Pulg }\end{array}$} & \multicolumn{2}{|c|}{ Comprimento de revestimento } & \multirow{2}{*}{$\begin{array}{c}N . E \\
m\end{array}$} & \multirow{2}{*}{$Q(\mathrm{~m} 3 / \mathrm{h})$} & \multirow{2}{*}{ Observaçöes } \\
\hline & & & Lat & Long & & & & & Revestimento (m) & Filtro (m) & & & \\
\hline 10 & Tripartito & Palca-Peru & 8065,12 & 450,49 & 4068.62 & 69 & 67 & 4 & 02 & 65 & 27,11 & 10 & $\begin{array}{c}\mathrm{Ce}=87.7, \mathrm{t}=6.8 \\
\mathrm{pH}=8.32\end{array}$ \\
\hline 11 & Charaña & $\begin{array}{l}\text { Pacajes - } \\
\text { Bolivia }\end{array}$ & 8055,22 & 452,89 & 4054,42 & 34 & 34 & 6 & 02 & 32 & 9,08 & 7,2 & $\begin{array}{c}\mathrm{Ce}=480, \mathrm{t}=10.4, \\
\mathrm{pH}=7.37\end{array}$ \\
\hline Ch-AlT & Charaña & Pacajes Bolivia & 8056,32 & 453,26 & 4049,32 & 200 & 130 & 12 & 100 & 30 & jorrante & 39,6 & \\
\hline
\end{tabular}

TABELA 20 - CADASTRAMENTO DE FONTES DE ÁGUAS SUPERFICIAIS.

\begin{tabular}{|c|c|c|c|c|}
\hline Manancial & $\begin{array}{c}N^{\circ} \\
\text { fontes }\end{array}$ & $\begin{array}{l}\mathrm{Q} \mathrm{m}^{3} / \mathrm{h} \\
\text { Media }\end{array}$ & Formação & Observaçōes: \\
\hline boçoroca Queñuta & 9 & 129,6 & Maure & $\begin{array}{l}\text { Fornecem água a terras baixas e alagadiças, drenam em direçäo a planicie Vilacollo, logo são captados pelo canal } \\
\text { Uchusuma }\end{array}$ \\
\hline Vilapucara & 8 & 54,0 a 97,2 & Maure & $\begin{array}{l}\text { Nasce no extremo Leste do nevado Condorpico no sopé colina Cumbre Rumi. Os mananciais emergem da Formaçăo } \\
\text { Maure com uma vazões variáveis. }\end{array}$ \\
\hline Charaque e Culco & 2 & 86,4 a 14,4 & $\begin{array}{l}\text { Vulcânico } \\
\text { Barroso }\end{array}$ & $\begin{array}{l}\text { Nas proximidades da estrada que conduz a Paucarani aflora o primeiro manancial, e segundo manancial no local Culco } \\
\text { na margem do rio Uchusuma. }\end{array}$ \\
\hline Charaque e Cuico & 1 & 93,6 & $\begin{array}{l}\text { Vulcânico } \\
\text { Barroso }\end{array}$ & Aflora nas proximidades da estrada em direção a Paucarani. Estas deságuam no rio Uchusuma. \\
\hline $\begin{array}{l}\text { Manancial ; Lagoa } \\
\text { Ancochaullane }\end{array}$ & 3 & 100,8 a 129,6 & Barroso & $\begin{array}{l}\text { Próximo à elevaçāo cerro Ancochaullane (NW da planície Ayro) apresenta-se uma lagoa parcialmente seca, onde aflora } 3 \\
\text { fontes constituindo pequenos tributário do rio Uchusuma }\end{array}$ \\
\hline Paucarani & 1 & 244,8 & Barroso & Próximo ao lago Paucarani e local Calachata aflora o manancial hidrotermal \\
\hline Cruz Pujo & 2 & 172,8 a 273,6 & $\begin{array}{l}\text { Zona de } \\
\text { Contato }\end{array}$ & $\begin{array}{l}\text { Afloram fontes de água hidrotermal, próximo ao local Huaylluta. As águas emergem de arenitos de cor amarelo tênue } \\
\text { que aflora no contato com o vulcânico vulcânico Barroso. }\end{array}$ \\
\hline Ayro & 3 & 61,2 & $\begin{array}{l}\text { Quat fluvio } \\
\text { glacial }\end{array}$ & Afloram no extremo Sul da lagoa Blanca \\
\hline Rio Uchusuma & & 2113,2 & & Vazão medido na Bocatoma Uchusuma - Ayro Nuevo \\
\hline Lagoa Paucarani & \multicolumn{4}{|c|}{$\begin{array}{l}\text { Barragem localizado a } 4500 \mathrm{~m} \text { de attitude na zona Norte da bacia, foi construido entre } 1981-86 \text {. A capacidade de armazenamento } 8^{\prime} 500.000 \mathrm{~m}^{3} \text { verte uma vazāo } \\
\text { aproximada de } 900 \mathrm{~m}^{3} / \mathrm{h} \text {. }\end{array}$} \\
\hline Lagoa Blanca & \multicolumn{4}{|c|}{$\begin{array}{l}\text { De dimensão } 6 \mathrm{Km} \text { de comprimento, localizada na planície Vilacollo }(4238 \text { a } 4250 \mathrm{~m} \text { ) Esta lagoa encontra-se em processo de extinção, apresenta alta } \\
\text { concentração de sais na superficie por processo de evaporação. Contribui ao rio Uchusuma com uma vazão de } 57,6 \mathrm{~m}^{3} / \mathrm{h} \text { através da quebrada Ancuyo } \\
\text { Localiza-se no nevado Condornico }\end{array}$} \\
\hline $\begin{array}{l}\text { Lagoa Condorpico l e } \\
\text { Condorpico II }\end{array}$ & \multicolumn{4}{|c|}{$\begin{array}{l}\text { Localiza-se no nevado Condorpico. Ocupa uma depressão antiga do circo glacial abrangendo uma área de } 48.280 \mathrm{~m}^{2} \text {. O volume armazenado nos dois lagoas } \\
\text { aproximadamente é de } 3 \times 10^{6} \mathrm{M}^{3} \text { (PET; Tacna). Esta lago é regulado por uma comporta de uma pequena barragem e descarrega uma vazão aproximada de } \\
360 \mathrm{~m}^{3} / \mathrm{h} \text { suas águas no rio Uchusuma proximo no local Uncalluta. }\end{array}$} \\
\hline
\end{tabular}




\subsection{0.- Características sedimentares dos sistemas aqüiferos}

No capitulo da geologia foi descrito a seqüência estratigráfica da sub-bacia, destacando-se do ponto de vista hidrogeológico, a presença de um aqüífero profundo com características de semi-confinado reconhecido como aqǘf́fero da Formação Maure de idade Plioceno inferior. No topo desta formação sobrepõe-se os ignimbritos impermeáveis da Formação Sencca, ou Pérez, afetados por uma tectônica rúptil, e sobre esta unidade, descansa o aqüifero livre da Formação Capillune de idade Plioceno. As condições sedimentares e estruturais associadas a esta seqüência mostram condições favoráveis para o armazenamento e dinâmica das águas subterrâneas.

As características sedimentares foram analisadas a partir de um conjunto de dados provenientes da geologia, geomorfologia, prospeção geofísica e correlação de perfis estratigráficos de poços. Toda esta informação associada permitiu a reconstrução paleomorfológica e conhecimento do modelo sedimentar da área de estudo. A análise e interpretação de dados apresenta-se nos diferentes perfis geológicos - geofísicos elaborados para este fim.

Com o intuito de apresentar uma descrição localizada e detalhada das características sedimentares da sub-bacia, os diferentes perfis geológicos geofísicos (FIGURAS 19, 20, 21., p: 77, 78, 79) mostram o panorama geral do reservatório geológico e suas variações faciológicas da seqüência sedimentar descritas a seguir:

\subsection{1.- Aqüífero livre}

Área 1.- A Formação Capillune constitui o aqüifero livre desta área composta por um conjunto sedimentar de tipo lacustrino - fluvial, intercalado com uma seqüência vulcano-sedimentar e no topo, depósitos fluvioglaciais e aluviais recentes. Esta seqüência apresenta como limites de contorno as rochas da Cordilheira o Barroso (Ts-vba), que circunda de norte a oeste, e em direção E, SE, uma área de descarga, ou saída, que abrange as planícies de Charaña Pampa. 
Quanto à natureza sedimentar do aqüifero, os depósitos flúvioglaciais na área que abrange a cabeceira do rio Uchusuma, estas apresentam uma mistura de fragmentos polimicticos de diferentes diâmetros englobados em uma matriz de areia e siltes. Na jusante do rio Uchusuma e áreas adjacentes os depósitos flúvioglaciais e aluviais recentes gradualmente passam a areias cascalhosas, englobando fragmentos angulosos a subangulosos em matriz siltosa, argilosa, com espessura de $27 \mathrm{~m}$ no poço PA7 diminuindo a $3,6 \mathrm{~m}$ na planície de Humapalca, a $20 \mathrm{~m}$ no poço PA 10 ., (Perfil CC' FIGURA 20, p: 78)

Os depósitos flúvioglaciais descritos, em profundidade entram em contato com depósitos da Formação Capillune (Tp-ca), compostos por uma intercalação de material vulcano-sedimentar: cascalhos de granulometria variada, areias, siltes, argilas e camadas de material vulcânico redepositado. A distribuição de espessura das camadas não é uniforme variando tanto na horizontal como na vertical.

No perfil CC (FIGURA 20, p: 78), salienta-se um paleovale sepultado por depósitos da Formação Capillune e materiais recentes. A natureza dos materiais preenchidos, segundo os registros dos poço PA-7 e PA-5 (ANEXO 11), está composto por uma intercalação de camadas de areias, siltes e argilas, de espessuras variadas. Esta forma de distribuição têm gerado condições locais de confinamento de águas que se deslocam ao longo da boçoroca Venada e Queñuta. Por esta razão os poços PA-7 e PA-5 mostram caracteristicas de artesianismo. Além do mais, na área de lagoa Blanca, a Formação Capillune entra em contato direto com o aqüífero da Formação Mauri (FIGURA 20), observado-se os ignimbritos da Formação Sencca erodidos e afetados por uma falha nesta área.

Como característica local, na área da lagoa Blanca, o aqüífero Capillune atinge a máxima espessura de $210 \mathrm{~m}$, com resistividades de 25 ohm.m a 54 ohm.m, diminuindo sua espessura notoriamente em direção NE até 24 $\mathrm{m}$ no poço PA-1. 
Hidrogeológicamente, entre o aqüifero Capillune e o aqüifero Maure existe uma interconexão hidráulica direta. Determinou-se fluxos ascendentes da Formação Maure para a Capillune por meio de falhas que atravessam a Formação intermediaria Sencca. Esta característica favorece a recarga do aqüifero livre e na capacidade de produção dos poços de produção localizados na zona do Ayro. A vazão específica estimada é $4,68 \mathrm{~m}^{3} / \mathrm{h} . \mathrm{m}$.

De outro lado, a morfologia das curvas equipotencias do aquifero livre na zona do Ayro (área1) mostram uma tendência de fluxos de N.W. a SE. Próximo a lagoa Blanca, uma parte dos fluxos segue direção sul para o território chileno, e outra parte dos fluxos segue direção NE, congruente ao curso do rio Uchusuma (FIGURA 26, p: 89)

Área 2.- Nesta área o aqüífero livre está representado pela Formação Charaña, equivalente a depósitos flúvioglaciais da área 1. Sua litologia está composta por sedimentos lacustrinos: diatomitos interestratificados com areias a siltes, que passam em gradação continua a seqüências de areias finas a grossas, cascalhos finos parcialmente litificados, seixos arenosos e camadas de cinza vulcânica em diferentes níveis, cuja espessura atinge 31 m. (poço PCh-ALT ANEXO II), (FOTO 8, p: 64). Na imagem de satélite (FIGURA 14, p: 53) observa-se à Formação Charaña com caracteristicas morfológicas de depósitos de leque aluvial abrangendo parte dos territórios de Chile e Bolivia no setor NE da área de estudo.

A Formação mencionada entra em contato seqüencial progressivo com aqüífero Capillune a uma profundidade de $31 \mathrm{~m}$ que foi determinado na amostragem da seqüência estratigráfica do poço de Charaña (PCh-ALT) (FIGURA 22). As duas formações Charaña e Capillune atingem uma espessura de $56 \mathrm{~m}$ constituindo o aqüifero livre desta zona. Nas sondagens esta seqüência apresenta resistividades entre 40 a 60 ohm.m e, em profundidade, entra em contato com a Formação Sencca, ou Pérez.

\subsection{2.- Aqüífero semiconfinado}

Na área 1 destaca-se a presença da Formação Maure composta por uma litología vulcano-sedimentar. Por sua posição estratigráfica e aspectos 
estruturais relacionados a esta formação, definiu-se como um aqüifero semi-confinado. Alguns características intrínsecas desta formação apresenta-se na descrição por áreas, a seguir:

Área 1.- Durante os trabalhos de campo foram observados numerosos afloramentos de mananciais no entorno dos morros Vilacollo e ao longo dos cursos dos pequenos rios Patapujo e Vilapucara, os quais estão ligados a umas camadas de arenitos de cor verde cinza e cor amarela da Formação Maure. O perfil litológico do poço PA-10 (ANEXO II) apresenta uma informação detalhada das características sedimentares desta formação. A sondagem tem uma profundidade de $255 \mathrm{~m}$ perfurados na zona do Ayro -Peru, onde a Formação Maure encontra-se de $102 \mathrm{~m}$ a 255 $m$ de profundidade.

O aqüífero Maure está constituído por uma seqüência vulcano-sedimentar interestratificada por arenitos verde escuros, arenitos quartzosos, de grão fino a grosso, horizontes de piroclastos retrabalhados, conglomerados, siltitos, tufitos cinza, dacíticos de cor branca amarela e argelitos. A espessura desta formação não foi determinada nas sondagens, porém foi possivel tomar informação do registro litológico do poço PA-10 onde foi constada uma espessura de $153 \mathrm{~m}$, embora nos poços PA-3 e PA-6 apenas tenham sido descritas espessuras de 21 e $62 \mathrm{~m}$, respectivamente.

O aqüifero Maure possui características de aqüifero semi-confinado, devido que os ignimbritos da Formação Sencca, ou Pérez, presentes no topo do aqüifero, encontram-se afetados por falhas. Isto permite o fluxo vertical das águas subterrâneas, embora esta formação seja de natureza impermeável, os aspectos estruturais determinam seu comportamento semi-confinado. Quanto ao contato estratigráfico na base do aqüifero, este não foi reconhecido. É possivel que estejam presentes rochas do Vulcânico Huilacollo do Terciário inferior.

Área 2.- Nesta área o aqüifero Maure não exibe afloramentos em superfície; porém, foi reconhecido durante a perfuração de um poço de 200 $\mathrm{m}$ de profundidade no vale do rio Uchusuma, para abastecimento de água 
ao povoado de Charaña. No topo do aqüifero apresentamse o vulcânico Sencca com uma espessura de $35 \mathrm{~m}$, confinando parcialmente ao aqüífero Maure. A litologia do aqüífero está constituída por uma interestraficação de conglomerados quartzosos de cor branca rosa, arenitos de grão médio a grosso de cor amarela e verde pálido, com horizontes de siltes e argilas. Em profundidade esta seqüência muda para camadas interestratificadas de arenitos finos, argilitos, siltitos de cor verde petróleo e material vulcânico retrabalhados. A espessura reconhecida do aqüifero Maure no poço de Charaña foi de $109 \mathrm{~m}$.

Por suas características sedimentares toda esta seqüência corresponde a depósitos de ambiente lagunar, interrompido por acumulaçōes de material da atividade vulcânica dos Andes.

\subsection{0.- Geometria do reservatório e do aqüífero}

A área possui, como condição de contorno hidrogeológico local, os domínios da Formação vulcânico Barroso, que circundam a sub-bacia e, em profundidade por sua posição estratigráfica, está limitada pela Formação Vulcânico Huilacollo do Terciário inferior, na área 1 e derrames de lava da Formação Abaroa na área 2

As características geométricas do reservatóriio da sub-bacia Uchusuma, estão diretamente controladas por sistema de falhas $\mathrm{N}-\mathrm{S}$ e outras falhas transversais, descrita nos capítulos precedentes.

Na zona do Ayro - Peru (área 1) as falhas delimitam uma área de depressão de $300 \mathrm{~m}$ de profundidade aproximada, preenchido por materiais vulcanosedimentares da seqüência Maure, Sencca y Capillune. Quanto às características geométricas dos aqüíferos, observando os perfis $A^{\prime}$ ', BB' e CC (FIGURAS 19,20., p:77,78) distingue-se a Formação Capillune, com uma forma tabular nas planícies de Vilacollo (FIGURA CC), com diminuição da espessura em direção leste, produto da erosão dos sedimentos Capillune. Esta superfície erodida encontra-se coberta por uma delgada camada de material flúvioglacial. No extremo oeste do perfil cc observa-se uma zona de depressão relacionada a um paleovale, onde a Formação Capillune atinge a máxima espessura de 210 metros, entrando em contato com a Formão Maure. Em profundidade a Formação Maure apresenta-se 
parcialmente confinada e moderadamente deformada, exibindo afloramentos em superfície na zona E,NE. De modo geral, as formações sedimentares desta área possuem uma geometria irregular, controlada por ação geodinâmica dos episódios do Pleistoceno, que definiram uma acumulação quase tabular dos materiais Maure, Sencca e Capillune.

$\mathrm{Na}$ área 2, zona de fronteira Peru-Chile e Bolívia (NE da sub-bacia), a imagem de satélite Landsat mostra nitidamente a amplitude do leque aluvial da Formação Charaña, e a origem dos materiais desta formação, que foram preenchendo as pequenas bacias de ambiente lagunar que existiram no lado boliviano durante o Plioceno. Estas foram soterradas por aluviões provenientes da zona do Ayro Peru. Esta composição de materiais de ambiente lagunar e depósitos de leque aluvial compõem o aqüífero livre na zona de fronteira.

Na zona da Bolívia a seqüência Formação Mauri, Pérez, e Charaña, está controlada pela geometria da bacia desenvolvida por uma tectônica de depressão de blocos de fase compressiva, aspecto que se desprende das características tectônicas regionais, facilitando o desenvolvimento local de pequenas bacias sedimentares.

\subsection{0.- Potenciometria.}

Foram realizadas campanhas de medição da variação sazonal do nivel da água na rede de poços de monitoração referenciados a cotas topográficas. Em áreas de escassa informação hidrogeológica, como a zona de Charaña - Bolivia, instalou-se 07 poços de monitoramento, com a finalidade de medir as variações potenciométricas do aqüífero livre, realizar amostragem para determinar a qualidade das águas. As profundidades dos poços não ultrapassam $14 \mathrm{~m}$. 0 período de observação foi de outubro de 2000 até março 2003.

Com base na informação coletada foi elaborado mapa potenciométrico, (FIGURAS 26, p:89) para diferentes épocas de observação, com a finalidade de determinar a direção de fluxo de águas subterrâneas, gradiente hidráulico e variações sazonais. Os resultados da informação processada para o período observado 2000 - 2003, mostram a tendência de fluxos das águas no aqüifero livre Capillune (área 1). Nesta área observa-se deslocamentos em duas direções: o primeiro 
congruente com sentido de fluxo das águas do rio Uchusuma e outro em direção a lagoa Blanca, cujas águas são drenadas através da estrutura de falha (F4), que ingressa no território chileno seguindo a direção SW. Na zona de Charaña (área 2) a direção de fluxo de águas no aqüífero livre desloca-se de oeste para leste.

\subsection{1.- Dinâmica de flutuações do nível da água do aqüífero freático.}

Com a finalidade de avaliar as variações do nível da água do aqüífero freático fizeram-se seis campanhas de medições nos diferentes poços de observação, com uma periodicidade de seis meses iniciando-se os trabalhos no mês de outubro do ano 2000 a março de 2003. Os resultados são apresentados na TABELA 21 e 22.

Com os dados levantados do período observado, estimou-se as variações máximas do nivel da água para épocas de rebaixamento máximo e época de recarga que o sistema recebe. Quanto às variaçōes do nível potenciométrico do aqüífero confinado, não foi possível controlá-las por falta de condições operacionais para realizar medições.

Na zona de "El Ayro" (área 1), o nivel da água pode ser localizado em função das cotas topográficas dos pontos de controle. Nas zonas altas, acima da cota 4300 m, em lugarejos como San Pedro de Calacollo, Culco e Calaparque, o nível da água pode ser encontrado segundo a época do ano a uma profundidade média de $14,60 \mathrm{~m}$. Em zonas baixas, ao longo das planícies da lagoa Blanca, o nível da água encontra-se próximo a superficie $(0,14 \mathrm{~m})$ ou fornam alagadiços.

Na zona de Charaña (área 2), em temporada de estiagem, o nível da água encontra-se a uma profundidade máxima de 13,20 $\mathrm{m}$ nas colinas de Estancia Jiscojo- da Bolívia (poço 4) e uma mínima de $2,60 \mathrm{~m}$ na zona baixa Estancia de Challawilque da Bolivia (poço 9). 
TABELA.21. MEDIDAS DE FLUTUAÇÕES DO NIVEL DA AGUA NA ZONA DO AYRO (ÁREA 1)

\begin{tabular}{|c|c|c|c|c|c|c|c|c|c|c|c|c|c|}
\hline \multirow{3}{*}{$\begin{array}{l}\text { Número } \\
\text { do Poço }\end{array}$} & \multicolumn{4}{|c|}{ Localização } & \multicolumn{9}{|c|}{ Dados de mediçä́o do nivel da água ( metros) - periodo outubro 2000 a março } \\
\hline & \multirow{2}{*}{ Localidade } & \multirow{2}{*}{ Pro./Pais } & \multicolumn{2}{|c|}{ Coordenadas UTM } & \multirow{2}{*}{$\begin{array}{l}\text { Cota } \\
(m)\end{array}$} & \multirow{2}{*}{$\begin{array}{l}\text { Ano } 2000 \\
\text { Outubro }\end{array}$} & \multicolumn{2}{|c|}{ Ano 2001} & \multicolumn{2}{|c|}{ Ano 2002} & Ano 2003 & \multirow{2}{*}{$\begin{array}{l}\text { Flutuaçāo } \\
\text { Média }\end{array}$} & \multirow{2}{*}{ Observaçôes } \\
\hline & & & Lat & Long. & & & março & outubro & Março & outubro & março & & \\
\hline PA-1 & Ayro & Tacna - Peru & 8057,56 & 434,27 & 4261,91 & & & 26,18 & & & 24,75 & & \\
\hline PCA-1A & Ayro & Tacna - Peru & 8057,57 & 434,28 & 4261,95 & 26,20 & 25,28 & 25,97 & 25,22 & 26,10 & 25,70 & 0,98 & \\
\hline PA-2 & Ayro & Tacna - Peru & 8056,62 & 432,24 & 4259,50 & & 5,98 & & & 5,78 & & & \\
\hline PCA-2A & Ayro & Tacna - Peru & 8056,61 & 432,23 & 4260,00 & 7,31 & 7,03 & 7,11 & 6,62 & 7,08 & 6,42 & 0.89 & \\
\hline PA-3 & Ayro & Tacna- Peru & 8053,80 & 432,10 & 4254,04 & & & 2.71 & & & & & \\
\hline PCA-3A & Ayro & Tacna- Peru & 8054.15 & 432,30 & 4256,12 & 5.11 & 5.09 & 5.14 & 5.02 & 5.16 & 4.97 & 0.14 & \\
\hline PA-4 & Ayro & Tacna- Peru & 8055,80 & 434,15 & 4255,58 & & & 17.31 & & & & & \\
\hline PCA-4A & Ayro & Tacna-Peru & 8055,81 & 434,14 & 4256,49 & 16.42 & 16.32 & 16.58 & 16.48 & 16.64 & 16.36 & 0.32 & \\
\hline$P C A-4 B$ & Ayro & Tacna - Peru & 8055.60 & 433.90 & 4261,13 & 21.05 & 20.88 & 21.12 & 20.13 & 21.34 & 20.53 & 1.21 & \\
\hline PA-5 & Ayro & Tacna - Peru & 8051,75 & 431,45 & 4252,19 & & & & & & & & Poço jorrante \\
\hline PCA-5A & Ayro & Tacna - Peru & 8051,80 & 431,40 & 4253,28 & 0.14 & 0,08 & 0,16 & 0,09 & 0,11 & 0,07 & 0,09 & \\
\hline PA-6 & Ayro & Tacna- Peru & 8060,79 & 434,42 & 4263,71 & 0,18 & & & & & 0,6 & & Poço jorrante \\
\hline PCA-6A & Ayro & Tacna- Peru & 8061.00 & 434,35 & 4267,59 & 2,11 & 1,64 & 2,18 & 1,52 & 2,23 & 1,54 & 0,59 & \\
\hline PA-7 & Ayro & Tacn a - Peru & 8049,78 & 429,55 & 4251,05 & 0,04 & & & & 0,09 & & 0,09 & Poço jorrante \\
\hline PCA-7A & Ayro & Tacna-Peru & 8049,85 & 429,55 & 4247,71 & 0,18 & 0,06 & 0,20 & 0,09 & 0,17 & 0,10 & 0,14 & \\
\hline PA-9 & Ayro & Tacna- Peru & 8060,28 & 434,63 & 4251,77 & & 14,19 & & & & & & \\
\hline PA-10 & Ayro & Tacna - Peru & 8059,07 & 434,37 & 4255,14 & 17,68 & 17,11 & & 17,08 & 17,69 & 17,04 & 0,64 & \\
\hline PA-12 & Ayro & Tacna - Peru & 8064,06 & 434,48 & 4337,26 & 5,01 & & 5,29 & & & 4,84 & 0,45 & \\
\hline PA-13 & Ayro & Tacna - Peru & 8064,73 & 434,61 & 4361.90 & 12,54 & 12,48 & 12,94 & 12,39 & 13,16 & 12,21 & 0,95 & \\
\hline $\mathrm{CA}-2$ & Ayro & Tacna - Peru & 8051,90 & 427,10 & 4275,49 & 19,93 & 19,18 & 19,49 & 19,39 & 19,42 & 19,21 & 0,75 & \\
\hline $\mathrm{CA}-3$ & Ayro & Tacna - Peru & 8054,30 & 430,10 & 4286,36 & 22,19 & 22,04 & 22,31 & 22,06 & 22,17 & 22,08 & 0,27 & \\
\hline $\mathrm{CA}-4$ & Ayro & Tacna - Peru & 8055,20 & 425,90 & 4326,95 & 42,06 & 42,10 & 42,08 & 41,93 & 42,01 & 41,96 & 0,17 & \\
\hline$C A-5$ & Ayro & Tacna - Peru & 8054,90 & 424,90 & 4428,96 & & & & & & & & \\
\hline CA- 6 & Ayro & Tacna - Peru & 8057,40 & 423,65 & 4370,98 & 14,60 & 13,82 & 14,40 & 14,02 & 14,63 & 13,92 & 0.71 & \\
\hline $\mathrm{CA}-7$ & Ayro & Tacna - Peru & 8057,25 & 430,10 & 4298,31 & 14,59 & 13,97 & 14,39 & 14,52 & 14,92 & 13,92 & 1,00 & \\
\hline
\end{tabular}


TABELA 22: MEDIDAS DE FLUTUAÇŌES DO NIVEL DA AGUA NA ZONA DE CHARAÑA - BOLIVIA (ÁREA 2)

\begin{tabular}{|c|c|c|c|c|c|c|c|c|c|c|c|c|c|}
\hline \multirow{3}{*}{$\begin{array}{l}\text { Núm. } \\
\text { do } \\
\text { Poço }\end{array}$} & \multicolumn{4}{|c|}{ Localizaçāo } & \multirow{3}{*}{$\begin{array}{l}\text { Cota } \\
(m)\end{array}$} & \multicolumn{8}{|c|}{ Dados de medição do nivel da água (metros) - periodo outubro 2000 a março 2003} \\
\hline & \multirow{2}{*}{ Localidade } & \multirow{2}{*}{ Pro./Pais } & \multicolumn{2}{|c|}{ Coordenadas UTM } & & \multirow{2}{*}{$\begin{array}{c}\text { Ano } 2000 \\
\text { Outubro }\end{array}$} & \multicolumn{2}{|c|}{ Ano 2001} & \multicolumn{2}{|c|}{ Ano 2002} & \multirow{2}{*}{$\begin{array}{l}\text { Ano } 2003 \\
\text { março }\end{array}$} & \multirow{2}{*}{$\begin{array}{l}\text { Flutuação } \\
\text { Média }\end{array}$} & \multirow{2}{*}{ Observações } \\
\hline & & & Lat. & Long. & & & março & setembro & Março & Setembro & & & \\
\hline 1 & Lupirani & Charaña & 8053,49 & 451,65 & 4057,94 & 7,12 & 6,04 & 7,16 & 6,91 & 7,14 & 5,96 & 1,20 & \\
\hline 2 & $\begin{array}{c}\text { Est. } \\
\text { Calacalani }\end{array}$ & Charña & 8056,19 & 451,22 & 4063,57 & 10,87 & 9,82 & 11,02 & 9,97 & 10,96 & 9,63 & 1.39 & \\
\hline 3 & Est. Iruvinto & Charaña & 8057,36 & 451,39 & 4065,74 & 13,28 & 12,03 & 13,15 & 12,64 & 13,04 & 11,98 & 1,30 & \\
\hline 4 & Est. Jiscojo & Charaña & 8057,83 & 452,13 & 4066,08 & 13,22 & 12,14 & 13,26 & 12,23 & 13,19 & 12,08 & 1,18 & \\
\hline 5 & Charan̄a & Charaña & 8055,64 & 453,26 & 4050,37 & 6,99 & 6,08 & 6,83 & 6.11 & 6,97 & 5,83 & 1.14 & \\
\hline 6 & $\begin{array}{l}\text { Est. } \\
\text { Llapallapani }\end{array}$ & Charaña & 8057,57 & 454,18 & 4046.46 & 7,28 & 6,16 & 7,28 & 6,29 & 7,21 & 6,12 & 1,16 & \\
\hline 7 & $\begin{array}{l}\text { Est. Agua } \\
\text { Rica }\end{array}$ & Charaña & 8055,52 & 454,09 & 4043,85 & 4,08 & 3,12 & 3,92 & 3,02 & 3,84 & 2,98 & 1,1 & \\
\hline 8 & Est. Ventilla & Charaña & 8057,22 & 454,58 & 4046,79 & 7,26 & 6,11 & 7,29 & 6,19 & 7,18 & 6.08 & 1,21 & \\
\hline 9 & $\begin{array}{l}\text { Est. } \\
\text { Challawilque }\end{array}$ & Charaña & 8055,81 & 455,16 & 4037,44 & 2,64 & 1,89 & 2,52 & 1,92 & 2,49 & 1,86 & 0,78 & \\
\hline 10 & Triparito & Palca - Peru & 8065,12 & 450,49 & 4068,62 & 27,17 & 26,18 & 27,21 & 26,20 & 27,18 & 26.13 & 1,08 & \\
\hline 11 & Charaña & Pacajes - Bolívia & 8055,22 & 452,89 & 4054,42 & 9,05 & 8,02 & 8,87 & 7,91 & 8,91 & 7,85 & 1,2 & \\
\hline $\begin{array}{l}\text { Ch- } \\
\text { ALT }\end{array}$ & Charaña & Pacajes Bolívia & 8056,32 & 453,26 & 4053.97 & 0,00 & 0,00 & 0,00 & 0.00 & 0,00 & 0.00 & 0,00 & Poço jorrante \\
\hline
\end{tabular}


Com dados do período monitorado foram elaborados mapas de contorno equipotencial (FIGURA 26, p: 89) para época de recarga ou de precipitação (Março) e para época de estiagem (Outubro). A morfologia das curvas permitiram a interpretação da direção predominante de deslocamento das águas subterrâneas em relação às flutuações do nível da água. Além do mais, foram avaliados problemas de impacto ambiental relacionados à extração das águas subterrâneas nos diferentes poços tubulares, cujo volume de explotação atinge uma vazão de $1375,20 \mathrm{~m}^{3} / \mathrm{h}$ (Autoridad Binacional del lago Titicaca, 1996).

As máximas flutuações encontradas para o período de observação é de $1,94 \mathrm{~m}$ na zona do El Ayro (área 1) e 1,40 m na zona de Charaña (área 2). Esta flutuação de fato está relacionada ao comportamento de regime de precipitação dos diferentes anos e épocas de estiagem. Os dados são expostos na TABELA 21, 22 que mostram a variação local para o período observado.

\subsection{2.- Interpretação da morfologia do nível da água do aqüífero freático}

As águas subterrâneas adotam um sentido de fluxo em função de zonas de recarga e proximidade ou afastamento de zonas de descarga, de modo concordante à morfologia do terreno. Para a zona de estudo elaborou-se o mapa de curvas equipotenciais com dados do periodo observado. A morfologia das curvas (FIGURA 26, p:90) mostra, de maneira pouco evidente, a localização de zonas de recarga, que estas provem das áreas da Cordilheira El Barroso, deslocando-se em direção às planícies de lagoa Blanca onde esta o nível de base para esta zona.

As características morfológicas das curvas geradas evidenciam um deslocamento das águas em meios quase homogêneos, com áreas de descarga pouco influentes na direção de fluxos localizadas em duas frentes: a primeira em direção sul à zona de Lagoa Blanca, cujas águas são drenadas para bacias adjacentes através da falha F4 e a segunda tem direção de deslocamento segundo uma orientação Leste, ao longo da planicie Salamaque, congruente ao rio Uchusuma. O gradiente hidráulico estimado para esta área é de $1 \%$. 
Na zona de Charaña (área 2), onde localiza-se o leque aluvial, o fluxo das águas subterrâneas segue uma orientação E,NE em direção ao rio Kaño com um gradiente hidráulico de $1 \%$.

\subsection{0.- Aspectos de recarga de aqüífero.}

Do ponto de vista do desenvolvimento geológico da área de pesquisa, as áreas de recarga estão localizados no sopé dos nevados da Cordilheira El Barroso, constituída por materiais de origem fluvio glacial, de granulometria grossa com porosidades entre 30 a $40 \%$. Estas áreas são favorecidas pela qualidade de textura dos materiais existentes neste meio, condições que, ligado às estruturas locais de falhas e fraturas, são vias de recarga de aqüiferos.

As recargas recebidas pelos aqüiferos Maure e Capillune, procedem fundamentalmente, do regime pluviométrico regional. Segundo o balanço hídrico entre janeiro a março (época de precipitação), o aqüifero recebe a máxima recarga de $64,46 \mathrm{~mm} / \mathrm{ano}$. Além da precipitação o degelo de neves e aportes da infiltração das águas superficiais da lagoa Paucarani, lagoa Tiapujo, contribuem na alimentação continua, fundamentalmente do aqüífero Capillune.

O efeito de controle topográfico na infiltração das águas de escoamento superficial, é um fator muito importante na recarga de aqüiferos. Nas áreas baixas da sub-bacia o declive do terreno é moderado a baixo, e esta condição topográfica controla a velocidade e tempo de concentração das águas no curso dos rios, influi diretamente na infiltração e no escoamento superficial das águas. O valor estimado entre a cota mais alta, de $5742 \mathrm{~m}$ (Corditheira Barroso), e a cota mais baixa de $4065 \mathrm{~m}$ na confluência com o rio Putani na Bolivia, e para uma distância de alongamento da sub-bacia de $48,3 \mathrm{Km}$, o gradiente médio é de 3,4 $\%$. Em zonas de planície este valor é de 1,6\%, valor este que indica um relevo suave que facilita a infiltração de maior quantidade de água, pela menor velocidade de escoamento após a chuva, considerando que a velocidade de fluxo das águas é diretamente proporcional ao declive topográfica dos curso dos rios. O gradiente hidráulico médio calculado em função do perfil longitudinal do rio Uchusuma é de $1,1 \%$. 
Em épocas de estiagem o reservatório recebe recargas regionais provenientes do deslocamento de águas subterrâneas das estribações da Cordilheira Ocidental dos Andes. No Altiplano existe um predomínio de séries continentais plioquaternárias, onde as rochas vulcânicas encontram-se afetadas por deformações de caracter rúptil e vales intramontanhosos preenchidos de material fluvioglacial. As condições físicas dos meios fraturados e porosos favorecem a infiltração e recarga do aqüífero Maure e Capillune no âmbito regional e armazenamento de grandes volumes de água de infiltração no sistema.

É importante salientar que em alguns locais os depósitos quaternários, encaixados em vales intramontanhosos, formam aqüiferos isolados de pouca espessura e extensão limitada. O comportamento hidrodinâmico é de caráter local, seja freático ou confinado, e, em outras áreas, formam mananciais de regime temporário ou permanente, em função da alimentação que recebem. 


\section{CAPITULO VII}

\section{HIDRODINÂMICA}

O fluxo das águas em meios porosos ou fraturados são controlados pelas propriedades físicas do meio, os quais referem-se a aspectos de maior ou menor resistência que oferecem ao movimento das águas e capacidade de armazenamento como reservatório. Estas propriedades estão representadas por indices ou parâmetros hidrogeologicos, que podem ser quantificados através de testes hidrodinâmicos, facilitando o conhecimento das propriedades hidráulicas dos materiais que compõem o reservatório, como capacidade produtiva do meio e condições físicas do entorno. O conhecimento dos parâmetros hidrogeológicos permite a delimitação de áreas favoráveis para a perfuração de poços de produção, planejamento de distribuição de pontos de captação, e delimitar áreas vulneráveis de contaminação ou outros aspectos de interesse.

Um dos objetivos da pesquisa desenvolvida orientou-se para a avaliação dos parâmetros hidrodinâmicos e potencialidade dos recursos hídricos subterrâneos das formações pliocênicas da sub-bacia do rio Uchusuma. Com esta finalidade foram realizadas testes hidrodinâmicos em poços selecionados.

Os testes hidrodinâmicos, amplamente desenvolvidos e explicados por diferentes pesquisadores como VILLANUEVA \& IGLESIAS (1984), constituem métodos adequados na pesquisa e avaliação de:

a).- análise do poço como uma estrutura hidráulica projetada e construída para captação de águas subterrâneas; esta informação permite conhecer a qualidade da construção, perdas de carga no ingresso de água na zona de filtros, vazão de exploração sugerida; e

b).- análises do aqüífero, através da determinação de parâmetros hidrogeológicos, grau de comunicação entre zonas aqüiferas próximos ao poço e áreas afastadas, presença de fronteiras impermeáveis, zonas de recarga. 


\subsection{0.- Metodologia empregada}

\subsection{1.- Avaliação das características construtivas dos poços de produção}

Concordante com os objetivos da pesquisa foi necessário selecionar alguns poços para testes de bombeamento, e, também, para a estimativa de parâmetros hidrodinâmicos dos aqüiferos Capillune e Maure. Com esta finalidade avaliou-se as características construtivas dos poços profundos e poços de monitoração existentes na sub-bacia. O exame teve por objetivo obter informação relacionada ao comprimento do revestimento dos poços e filtros, localização dos filtros em relação às formações aqüiferas, distância de separação e relações entre poços de produção e poços de observação.

Da avaliação dos poços de produção existentes na zona do Ayro (TABELA 23), foram encontradas apenas dois poços que reuniam condições para a realização dos teste de bombeamento, que permitiram determinar os parâmetros do aqüifero Maure. Os poços selecionados foram: PA-6 da área 1 e seu poço de monitoração PCA-6 afastado a uma distância de 92,70 metros; o segundo poço escolhido foi PCH-ALT da área 2, localizado no vale do rio Uchusuma zona de Charaña, sem poço de observação.

O restante dos poços, não reuniam condições para estimar parâmetros hidrogeológicos que permitissem encontrar resultados confiáveis dos aqüiferos Maure e Capillune, pelas seguintes razões:

-- o desenho construtivo dos poços de produção apresentam uma zona de filtros localizados em todo o perfil do poço, envolvendo camadas da Formação Maure, Sencca e Capillune. Este critério construtivo tem gerado uma interconexão hidráulica vertical entre aqüíferos, como também influi no comportamento do aqüifero freático. Esta característica construtiva do poço não permitiu a determinação dos parâmetros representativos dos aqüiferos Maure e Capillune;

- o poço de produção e o poço de observação encontram-se localizados em diferentes formações, 
- quatro poços encontraram-se em estado de abandonado (PA-5, PA-7, PA-8, PA11) e três poços não operativos ou em estado de reserva (PA-10, PA-12, PA13).

Pelas razões expostas não foi possivel avaliar os parâmetros hidrogeológicos do aqüifero Capillune. Porém foram levadas em conta resultados de informações hidrodinâmicas do Instituto Nacional de Desarrollo Proyecto Especial Tacna em 1993.

TABELA 23 - AVALIAÇÃO DAS CARACTERISTICAS TÉCNICAS CONSTRUTIVAS DOS POÇOS DA ZONA DE AYRO E CHARAÑA.

\begin{tabular}{|c|c|c|c|c|c|c|c|c|c|c|}
\hline \multirow{2}{*}{ Poço } & \multirow{2}{*}{$\begin{array}{c}\text { Prof. } \\
\text { Perfurada } \\
\text { (m) }\end{array}$} & \multirow{2}{*}{$\begin{array}{c}\text { Distancia } \\
\text { PA - PCA } \\
\text { (m) }\end{array}$} & \multirow{2}{*}{$\begin{array}{c}\text { Prof. } \\
\text { Entubada } \\
(\mathrm{m})\end{array}$} & \multicolumn{2}{|c|}{ Desenho } & \multicolumn{4}{|c|}{$\begin{array}{l}\text { Localizaçäo de filtros nas } \\
\text { Formações atravessadas }\end{array}$} & \multirow{2}{*}{$\begin{array}{c}\text { Avaliaçăo de } \\
\text { condições } \\
\text { técnicas para } \\
\text { teste de } \\
\text { bombeamento }\end{array}$} \\
\hline & & & & $\begin{array}{c}\text { Revest } \\
\text { (m) }\end{array}$ & $\begin{array}{l}\text { Fittro } \\
(\mathrm{m})\end{array}$ & $\begin{array}{l}\text { Fluvio } \\
\text { glaciar }\end{array}$ & $\begin{array}{l}\text { Capi } \\
\text { llune }\end{array}$ & $\begin{array}{c}\text { Senc } \\
\mathrm{ca}\end{array}$ & $\begin{array}{c}\text { Maur } \\
e\end{array}$ & \\
\hline PA-1 & 177,00 & PA1 a & 105 & 23,00 & 82,00 & $x$ & & $x$ & $x$ & näo apta \\
\hline PCA-1 & 38,00 & $P C A 1=30,80$ & 38,00 & & & $x$ & $x$ & & & \\
\hline PA-2 & 150,00 & PA2 a & 150 & 12,00 & 138,00 & & $x$ & $x$ & $x$ & não apta \\
\hline PCA-2 & 21,00 & $\mathrm{PCA} 2=33,05$ & 21,00 & & & $x$ & $x$ & & & \\
\hline$P A-3$ & 120,00 & PA3 a & 119 & 2,00 & 117,00 & $x$ & $x$ & $x$ & $x$ & naีo apta \\
\hline$P C A-3^{A}$ & 25,50 & $\mathrm{PCA} 3 \mathrm{~A}=32,2$ & 25,50 & & & $x$ & $x$ & & & \\
\hline PCA-3B & 100,00 & PCA3B $=93,5$ & 100 & & & $x$ & $x$ & $x$ & $x$ & \\
\hline$P A-4$ & 100,00 & PA4-PCA4 & 99,00 & 9,00 & 90,00 & & $x$ & $x$ & $x$ & não apta \\
\hline PCA $-4^{A}$ & $32 ., 50$ & $P C A 4 A=30,9$ & 32,50 & & & & $x$ & $x$ & & \\
\hline PCA-4B & 75,00 & PCA4B $=203.5$ & 75,00 & & & & $x$ & $x$ & $x$ & \\
\hline PA-5 & 90,00 & PA5 a & 90,00 & 0,00 & 90,00 & & $x$ & & & Pọ̧o \\
\hline PCA-5 & 25,00 & $\mathrm{PCA}=99,70$ & 25,00 & & & & $x$ & & & abandonado. \\
\hline$P A-6$ & 66,00 & PA6 a & 64,00 & 5,00 & 59,00 & $x$ & & & $x$ & Boa para aquif. \\
\hline PCA-6 & 93,00 & $P C A 6=92,70$ & 93,00 & & & $x$ & & & $x$ & \\
\hline$P A-7$ & 103,00 & PA7 a & 102,00 & 5,00 & 97,00 & & $x$ & & & Poço abandonado \\
\hline PCA-7 & 23,00 & $P C A 7=99,70$ & 23,00 & & & & $x$ & & & \\
\hline$P A-8$ & & & & & & & & & & Pço abandonado \\
\hline$P A-9$ & 140,00 & & 133,00 & 0,00 & 133,00 & & & & & \\
\hline PA-10 & 250,00 & & & & & & & & & Poço de reserva \\
\hline$P A-11$ & 117,00 & & & & & & & & & Poço abandonado \\
\hline$P A-12$ & & & & & & $x$ & & & $x$ & Poço de reserva \\
\hline$P A-13$ & & & & & & & & & & Poço de reserva \\
\hline $\begin{array}{l}\mathrm{PCH} \\
\text { ALT }\end{array}$ & 200,00 & Sem PCA & 130,00 & 90,00 & 35,00 & & & & $x$ & Aqüifero Maure \\
\hline
\end{tabular}




\subsection{2.- Fundamentos de testes de bombeamento}

As diversas metodologias de análises de testes de bombeamento fundamentamse sobre algumas considerações de importância ou condições de contorno, para que o modelo matemático seja aplicável ao meio físico do aqüífero e do poço. Com tal finalidade o teste de bombeamento foi realizado nas seguintes condições:

a).- O meio físico da Formação Maure, caracterizado no capitulo 4, apresenta uma geometria e morfologia moderadamente irregular, com características de semiconfinado dentro do limite da sub-bacia. Porém, para aplicar as equações de análise e interpretação de testes de bombeamento, teoricamente pode ser considerado, com relativa aproximação, como aqüíferos homogêneos de extensão infinita. Os valores dos parâmetros podem mudar espacialmente de uma área a outra, de modo que, na interpretação dos resultados, deve-se ponderar as condições descritas.

b).- As condições estratigráficas dos poços de bombeamento e poços de observação são:

$\mathrm{Na}$ área 1, o poço de bombeamento PA-6, de 64 metros de profundidade, atravessa 6,80 m de material aluvial, e 57,20 m de material da Formação Maure, que corresponde a $33 \%$ de toda a espessura da formação, sendo por esta característica, um poço parcialmente penetrante. Por outro lado, o poço de observação PCA-6, localizado a uma distância de 92,70 m do poço de bombeamento, tem uma profundidade de $93 \mathrm{~m}$.

Na zona de Charaña (área 2) foi implementado um segundo poço de bombeamento PCH-ALT, perfurado durante a fase de pesquisa no ano 2000. Este poço tem uma profundidade de $130 \mathrm{~m}$, com uma zona de filtros localizados entre $95 \mathrm{~m}$ e $125 \mathrm{~m}$ de profundidade, para captar águas da Formação Maure,

c).- O teste foi realizado em diferentes datas durante o período de estiagem, em condiçōes de ausência de recargas exteriores ou presença de chuva, 
que pudessem causar interferência no rebaixamento do nível da água no poço.

d).- Durante o teste foi aplicada uma vazão constante de bombeamento de $Q=410,4 \mathrm{~m}^{3} / \mathrm{h}$ no poço PA-6 e $\mathrm{Q}=39,6 \mathrm{~m}^{3} / \mathrm{h}$ no poço $\mathrm{PCH}-\mathrm{ALT}$;

e).- O fluxo de água para o poço foi considerado radial e de regime variável.

f).- A superfície freática na área de influência do teste de bombeamento tem um gradiente hidráulico de $1,1 \%$ (quase horizontal).

\subsection{3.- Monitoramento de poços}

Além das características descritas no item anterior realizou-se um controle da evolução de níveis da água no poço de monitoramento em função do tempo de bombeamento. Os dados de teste de bombeamento, vazão e outros detalhes são apresentados nas TABELA 24,25.e. FIGURAS 27.(p: 114)

TABELA.24 - DADOS DE TESTE DE BOMBEAMENTO.

\begin{tabular}{|c|c|c|c|c|c|c|c|c|c|}
\hline \multicolumn{5}{|c|}{ Poço de bombeamento } & \multicolumn{3}{|c|}{ Poço de observação } & \multirow{2}{*}{$\begin{array}{l}\text { Distância } \\
\text { ao Poço } \\
\text { de bom. } \\
\quad(m\rangle\end{array}$} & \multirow{2}{*}{$\begin{array}{c}\text { Tempo de } \\
\text { resposta } \\
\text { no poço } \\
\text { PCA }\end{array}$} \\
\hline $\begin{array}{c}\text { Poço } \\
\text { PA }\end{array}$ & $\begin{array}{c}\text { Niv. Est. } \\
\text { (m) }\end{array}$ & $\begin{array}{l}Q \text { do teste } \\
\left(\mathrm{m}^{3} / \mathrm{h}\right)\end{array}$ & $\begin{array}{c}\text { Rebaixa- } \\
\text { mento } \\
\text { (m) }\end{array}$ & $\begin{array}{l}\text { Duraçäo } \\
\text { do teste. } \\
\text { (Horas) }\end{array}$ & PCA & $\begin{array}{l}\text { Niv. Est. } \\
\text { (m) }\end{array}$ & $\begin{array}{c}\text { Rebaixa } \\
\text { Mento } \\
(m)\end{array}$ & & \\
\hline 6 & 0,18 & 410,4 & 20,93 & 40 & 6 & 1,86 & 1,78 & 92,70 & $4 \mathrm{~min}$ \\
\hline$\frac{\mathrm{PCH}-\mathrm{ALT} T}{\mathrm{PCA}-\mathrm{P}}$ & 0,00 & 39.6 & 11,78 & 38 & & & & & \\
\hline
\end{tabular}
TABELA 25 - CARACTERISTICAS TÉCNICAS DOS POÇOS DE BOMBEAMENTO E POÇO DE
OBSERVAÇÄO

\begin{tabular}{|c|c|c|c|c|c|c|c|}
\hline \multicolumn{4}{|c|}{ Poço de bombeamento } & \multicolumn{3}{|c|}{ Poço de observaçăo } & \multirow{2}{*}{$\begin{array}{l}\text { Poço de } \\
\text { bombeameto } \\
\text { e Poço de } \\
\text { observação } \\
\text { no aqüifero }\end{array}$} \\
\hline $\begin{array}{c}\text { Poço Ayro } \\
\text { PA }\end{array}$ & $\begin{array}{c}\text { Prof. } \\
\text { Perfurada } \\
\text { (m) }\end{array}$ & $\begin{array}{c}\text { Prof. } \\
\text { Revestid } \\
a \\
m \\
\end{array}$ & $\begin{array}{l}\text { Localização de filtros } \\
\qquad(m)\end{array}$ & $\begin{array}{l}\text { Poço de } \\
\text { observaçăo } \\
\text { PCA }\end{array}$ & $\begin{array}{l}\text { Prof.perf. } \\
\qquad(\mathrm{m})\end{array}$ & $\begin{array}{l}\text { Localização } \\
\text { de filtros } \\
\text { (m) }\end{array}$ & \\
\hline \multirow[t]{2}{*}{6} & 66,00 & 64,00 & 3,00 a 28,00 & 6 & 93,00 & 0,00 a 93,00 & Maure \\
\hline & & & 31,00 a 64,00 & & & & \\
\hline PCH-ALT & 200,00 & 130 & 95,00 a 125,00 & & & & Maure \\
\hline
\end{tabular}

FONTE: Dados de Campo 


\subsection{0.- Análises e interpretação de testes de bombeamento}

Segundo FREEZE \& CHERRY (1979), KRUSEMAN \& RIDER (1970), VILLANUEVA \& IGLESIAS et al. (1984), a teoria de testes de bombeamento fundamenta-se nas leis que regem a hidráulica de meios porosos.

Estas leis resultam da aplicação da lei de Darcy dos meios porosos, ao teorema de continuidade, cuja equação fundamental é:

$$
\frac{\partial^{2} h}{\partial X^{2}}+\frac{\partial^{2} h}{\partial Y^{2}}+\frac{\partial^{2} h}{\partial Z^{2}}+\frac{F}{K}=\frac{S}{T} \cdot \frac{\partial \cdot h}{\partial \cdot t}
$$

Onde:

$$
\begin{aligned}
& h=\text { potencial hidráulico. (Niv. Potenciométrico) } \\
& F=\text { recargas exteriores (verticais, chuva, etc.) } \\
& K=\text { permeabilidade do aqüifero. } \\
& S=\text { coeficiente de armazenamento. } \\
& T=\text { coeficiente de transmisividade. } \\
& t=t e m p o .
\end{aligned}
$$

Os termos da expressão tem a seguinte interpretação física:

$$
\frac{\partial^{2} h}{\partial X^{2}}+\frac{\partial^{2} h}{\partial Y^{2}}+\frac{\partial^{2} h}{\partial Z^{2}} \text { ou } \nabla^{2} h \text { ou } \Delta h:
$$

Representa a soma das entradas e saídas de água em um cubo poroso elementar, cujo movimento é gerado pela diferença de carga hidráulica entre o cubo e zonas aqüiferas adjacentes.

$\frac{F}{K} \quad$ Representa as recargas de água ao sistema.

$\frac{S}{T} \cdot \frac{\partial h}{\partial \cdot t}$ Representa variação do armazenamento da água no cubo poroso elementar.

Deste modo a equação fundamental representa a diferença entre a quantidade de água que entra e sai pelas superficies planas de um cubo poroso ideal (diferença de carga hidráulica com zonas aqüíferas adjacentes), mais as entradas de água exteriores ao sistema. Este balanço deve ser igual a variação do armazenamento 
(VILLANUEVA \& IGLESIAS, 1984). Deste modo a equação é aplicável a análises de fluxo de águas nos aqüíferos.

No caso concreto de testes de bombeamento, é estudado o movimento das águas no meio poroso, como conseqüência da depressão do nível potenciométrico gerado por bombeamento em um poço. Considerando algumas simplificações que podem ser admitidas dentro da realidade física, como por exemplo: ausência de recargas exteriores ao sistema, onde $F / K=0$. O fluxo é radial e não existe componente vertical no eixo $O Z$, por conseguinte $\frac{\partial^{2} h}{\partial Z^{2}}=0$, etc. Com estas simplificações chega-se a diversos casos particulares de metodologia de interpretação de testes de bombeamento.

Conforme as condições de contorno do aqüífero Maure e do poço de bombeamento, aplicou-se, por se adaptar a este meio, o método gráfico de THEIS, para análise de teste de bombeamento realizado no poço PA-6, com observação no PCA-6, e para análise de teste de bombeamento do poço PCHALT aplicou-se o método gráfico de JACOB.

\subsection{1.- Fórmula de regime de não equilíbrio de Theis}

Na literatura de hidráulica de poços é amplamente conhecida a equação de Theis, desenvolvida para análise de teste de bombeamento aplicado a poços com fluxo em regime de não equilíbrio, onde o tempo de bombeamento tem efeito na descarga.

Os parâmetros do aqüífero podem ser estimados a partir do monitoramento da evolução do nivel da água em função do tempo:

$$
d=\frac{Q}{4 \pi T} \int_{i}^{x} \frac{e^{-u}}{u} d u \quad \text { equação de Theis } \quad \text { (11) } \quad u=\frac{r^{2} S}{4 T t}
$$

onde:

$d=$ rebaixamento no poço de observação a uma distância $r$ do poço de bombeamento.

$Q=$ vazão de bombeamento constante.

$T=$ transmisividade do aqüifero.

$S=$ coeficiente de armazenamento.

$T=$ tempo de duração do teste de bombeamento. 
A equação apresentada não facilita encontrar uma solução pelo método analítico, e por esta razão, Theis desenvolveu um método de solução pelo método gráfico, para estimar $\mathrm{T}$ e $\mathrm{S}$.

O método consiste na superposição de uma curva construida com dados do teste de bombeamento em escala logarítmica (tempo $t$ - rebaixamento d) e curva padrão de Theis, elaborada com dados de $(\log 1 / u)$ em função de $\log W(u)$. Deslocando-se a curva de campo paralelamente aos eixos $X, Y$ da curva padrão, até encontrar um setor de coincidência de melhor ajuste de curvas.

Para introduzir dados na equação de Theis, escolhe-se um ponto de coordenadas conhecidas da curva padrão $(W(u), 1 / u)$ e curva de campo $(t, d)$ com a finalidade de simplificar o cálculo, substituindo valores na equação o que permite estimar os parâmetros hidrodinâmicos.

O método gráfico de interpretação de Theis foi aplicado para estimar os parâmetros de transimisividade $(T)$, codutividade hidráulica $(k)$ e o coeficiente de armazenamento $(S)$ do aqüífero Maure, a partir de análise e interpretação de teste de bombeamento realizado no poço PA-6 com observações no poço PCA-6.

\subsection{2.- Fórmula modificada de regime de não equilíbrio - método de Jacob}

O método é baseado na equação simplificada de THEIS.

$$
d=\frac{Q}{4 \pi T} W(u), \text { Formula simplificada de Theis } \quad \text { (13) onde } u=\frac{r^{2} S}{4 T t}
$$

Jacob particulariza o método de Theis, onde a função $W(u)$, chamada função $(u)$ de poço, corresponde a integral exponencial:

$$
W(u)=\int_{u}^{\infty} \frac{e^{-u}}{u} d u=-0.5772-\log _{e} u+u-\frac{u^{2}}{2.2 !}+\frac{u^{3}}{3.3 !}-\frac{u^{4}}{4.4 !}+\ldots(14) \text { onde } u=1.87 r^{2} \mathrm{~S} / T t
$$

a equação apresentada é simplificada por um polinômio em série:

$$
W(u)=-0,577216-\operatorname{Ln} U+U-\frac{U^{2}}{2.2 !}+\frac{U^{3}}{3.3 !}-\frac{U^{4}}{4.4 !}+\ldots
$$

Nesta série de polinômio, a variável auxiliar $(u)$ pode tomar valores menores que 0,05 , quando aumenta $(t)$ e diminui $(r)$, neste caso pode-se negligenciar os termos 
que seguem aos dois primeiros monômios da equação (JONHSON,1978), e portanto, a expressão se reduz para:

$W(u)=-0,577216-\operatorname{Ln} U$

Em conseqüência, a equação (4) de Theis terá a seguinte expressão:

$d=\frac{Q}{4 \pi T}(-0,577216-\operatorname{Ln} U)$

Resolvendo, temos:

$$
\begin{aligned}
& d=\frac{Q}{4 \pi T}(\operatorname{Ln} 0,562-\operatorname{Ln} U) \\
& d=\frac{Q}{4 \pi T} \operatorname{Ln} \frac{0,562}{U}
\end{aligned}
$$

Substituindo $(u)$ por seu valor:

$$
\begin{aligned}
& d=\frac{Q}{4 \pi T} \operatorname{Ln} \frac{0,562 \times 4 T t}{r^{2} S} \\
& d=\frac{Q}{4 \pi T} \ln \frac{2,25 T t}{r^{2} S}
\end{aligned}
$$

Efetuando a divisão $1 / 4 \pi$ e multiplicando pelo fator 2,3 consegue-se transformar os logaritmos naturais em logaritmos decimais e assim, obter a equação de Jacob.

$d=0,183 \frac{Q}{T} \operatorname{Lg} \frac{2,25 T t}{r^{2} S} \quad$ Fórmula de Jacob

Onde:

$d=$ rebaixamento no ponto situado a distancia $(r)$ do poço de bombeamento $(m)$

$Q=$ vazão $\mathrm{m}^{3} /$ día.

$T=$ transmissividade $\mathrm{m}^{2} /$ día.

$S=$ coeficiente de armazenamento do aqüifero.

$t=$ tempo de decorrido do teste.

\subsection{3.- Aplicação do método de Jacob a análise do teste de bombeamento}

A determinação dos parâmetros hidrogeológicos consegue-se a partir dos dados de campo: 
a).- elabora-se, com os dados de teste de bombeamento, o gráfico tempo rebaixamento em folha semi-log. O tempo deve ser representado em escala logarítmica e o rebaixamento em escala aritmética.

Através dos pontos definidos deve-se traçar uma reta, observando-se que esta não deve passar por pontos localizados nos primeiros dez minutos, nem considerar o setor do gráfico que faz uma curva, por razões que neste segmento, o valor de (u) é maior a 0,05 e não se ajusta às condições do método de Jacob. Se $(u)$ é menor ao valor indicado, a aplicação do método conduz aos mesmos resultados que a fórmula de Theis ( JONHSON, 1978);

b).- a reta traçada determinará a diferença de rebaixamento para um ciclo logarítmico de tempo. Com estes dados substitui-se, na equação derivada de Jacob, o que permite calcular os parâmetros de transmissividade e coeficiente de armazenamento.

\subsection{0.- Parâmetros hidrodinâmicos}

TRANSMISSIVIDADE (T).

Segundo KRUSEMAN \& RIDER, (1970) este parâmetro indica a capacidade do aqüífero para transmitir água. Darcy a definiu como uma função que depende diretamente da condutividade hidráulica $(K)$ e da espessura do aqüifero $\left(H_{0}\right)$. A determinação deste coeficiente foi obtida a partir da interpretação, pelo método gráfico, do poço PA-6 e poço de observação PCA-6, e poço PCh-ALT (FIGURA 27), aplicando a seguinte fórmula:

Equação simplificada de Theis $T=\frac{Q}{4 \pi \Delta d} W(u)$.

Equação de Jacob

$$
T=\frac{0,183 Q}{\Delta s}
$$

$T=$ transmissividade $\mathrm{em} \mathrm{m}^{2} /$ día

$Q=$ vazão de bombeamento $\mathrm{m}^{3} /$ dia.

$\Delta d=$ rebaixamento no poço de observação para um ponto de coincidência $P$ com a curva padrão.

$W(u)=$ função $(u)$ do poço que se obtém do ponto escolhido da curva padrão

$\Delta s=$ Diferença de rebaixamento em um ciclo logarítmico (estão indicadas para cada caso). 
FIGURA 27 - CURVA REPRESENTATIVA DE TESTE DE AQÜIFERO POÇO PA-6 E PCH-ALT.

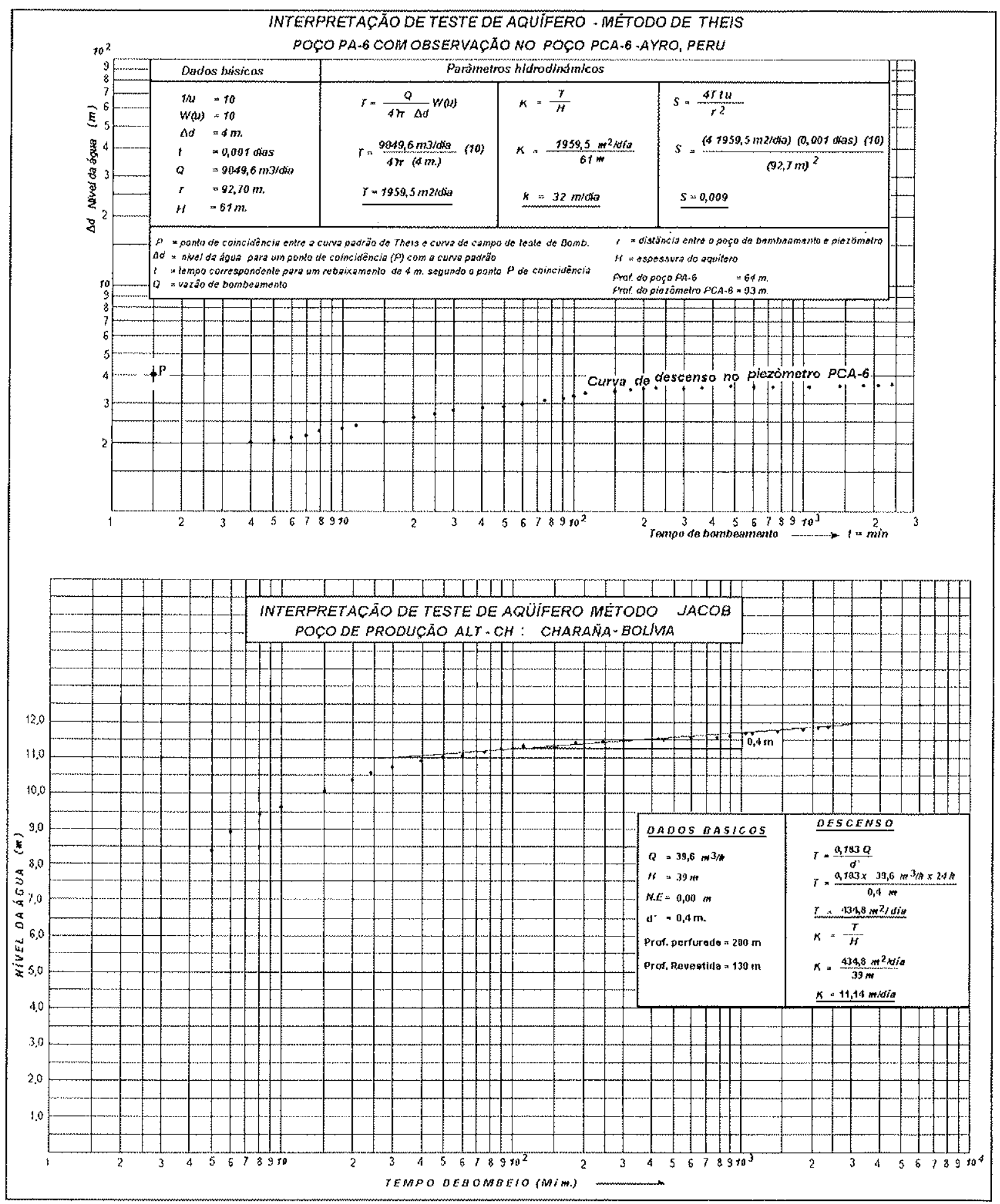


TABELA 26 - COEFICIENTES DE TRANSMISSIVIDADE DO AQÜIFERO MAURE

\begin{tabular}{ccccccc}
\hline $\begin{array}{c}\text { Zona de } \\
\text { avaliação }\end{array}$ & $\begin{array}{c}\text { Poço de } \\
\text { bombeamento }\end{array}$ & $\begin{array}{c}\text { Poço } \\
\text { Observ }\end{array}$ & $\begin{array}{c}\text { Distancia de } \\
\text { separação }(m)\end{array}$ & $\begin{array}{c}\text { T calculado } \\
\mathrm{m}^{2} / \text { dia }\end{array}$ & $\begin{array}{c}\text { Método de } \\
\text { interpretação }\end{array}$ & $\begin{array}{c}\text { Formação } \\
\text { aqüffera }\end{array}$ \\
\hline Area 1 & PA-6 & PCA-6 & 92,70 & 1959,5 & Theis & Maure \\
Area 2 & PCh-ALT & & & 434,8 & Jacob & Maure \\
\hline
\end{tabular}

FONTE: $O$ autor resultados de campo

PA: Poço Ayro, PCA: Poço de controle Ayro, PCh-ALT: Poço Charaña Autoridad Lago Titicaca.

Valor de transmissividade para aqüifero Capillune não foj determinado por razões que os poços PA-5 e PA-7, localizados dentro da Formação Capillune, encontram-se em um estado de abandono. Por esta situação assume-se como parâmetro referencial um $T=190 \mathrm{~m}^{2} / \mathrm{dia}$, valor que corresponde ao resultado de teste de bombeamento realizado no poço PA-5 pelo Instituto Nacional de Desarrollo. INADE-Tacna

Interpretação dos resultados: segundo os diversos pesquisadores, os valores de transmissividade maiores a $1000 \mathrm{~m}^{2} /$ dia, estão relacionados a poços que possuem vazão específica superiores a $36 \mathrm{~m}^{3} / \mathrm{h} . \mathrm{m}$, e valores de $100<\mathrm{T}<500$ estão relacionados a poços com vazão específica entre 3,6 e $18 \mathrm{~m}^{3} / \mathrm{h} . \mathrm{m}$ (VILLANUEVA, IGLESIAS 1984).

Nos anos de 1980 e 1985 a instituição "Instituto Nacional de Desarrollo - Proyecto Especial Afianzamiento y Ampliación de los Recursos Hidricos de los Departamentos de Tacna e Moquegua", como entidade executora de perfuração de poços, realizou testes de bombeamento em cada uma das obras de captação, determinando os parâmetros hidrodinâmicos, pelo método de Theis-Jacob. Os resultados apresentados na TABELA 27 correspondem a testes realizados no período citado. Estes valores são de caracter referencial pois os testes de bombeamento foram realizados em poços cujo projeto de filtros não reúnem condiçōes para estimar parâmetros especificos dos aqüiferos Maure ou Capillune. Porém servem de base para ponderar e fixar um valor de transmisividade média para o aqüífero Maure e Capillune, sendo estes valores próximos aos resultados encontrados. 
TABELA 27 - PARÂMETROS HIDRODINÂMICOS DETERMINADOS POR INADE "INSTITUTO NACIONAL DE DESARROLLO TACNA".

\begin{tabular}{|c|c|c|c|c|c|c|c|c|}
\hline \multirow[t]{2}{*}{ Poço } & \multirow{2}{*}{$\begin{array}{l}\text { Conductividade } \\
\text { hidráulica } \\
\mathrm{K}=\mathrm{m} / \mathrm{dia}\end{array}$} & \multicolumn{4}{|c|}{$\begin{array}{c}\text { Transmissividade } \\
\mathrm{T} \mathrm{m}^{2} / \mathrm{dia}\end{array}$} & \multicolumn{2}{|c|}{$\begin{array}{c}\text { Coeficiente de } \\
\text { armazenamento } \\
\mathrm{S}\end{array}$} & \multirow[t]{2}{*}{ Parâmetro do aqüiferc } \\
\hline & & $a$ & $\mathrm{~b}$ & $c$ & 0 & $e$ & $f$ & \\
\hline PA-1 & 86,4 & 790 & 767 & 751 & 700 & 0.28 & $2 \times 10^{-3}$ & Maure + fluviogl. \\
\hline PA-2 & 29,37 & 423 & 264 & 207 & 350 & & $1.4 \times 10^{-4}$ & Capillune + Maure \\
\hline PA-3 & 43,2 & 510 & 592 & 588 & 650 & & $2,4 \times 10^{-3}$ & Capillune + Maure \\
\hline $\mathrm{PA}-4$ & 74,3 & 617 & 521 & 705 & & & $1,4 \times 10^{-3}$ & Capillune + Maure \\
\hline PA-5 & & & & & 190 & & $1,7 \times 10^{2}$ & Capillune \\
\hline PA-6 & & & 1028 & 758 & 2250 & & $1,9 \times 10^{-3}$ & Maure \\
\hline PA.7 & & & 272 & 224 & & & $3,5 \times 10^{-2}$ & Capillune \\
\hline PA-9 & & & 330 & 340 & & & $6,4 \times 10^{-3}$ & Maure \\
\hline PA-11 & & & 463 & 234 & & & & Capillune +Maure \\
\hline
\end{tabular}

Valor de transmissividade para a $\mathrm{Fm}$ Capillune $=189,9 \mathrm{~m}^{2} / \mathrm{dia}$

$a$, e: Condutividade hidráulica estimado : Instituto de Desarrollo INADE Tacna, Vaiderrama P. 1981

b, f: INADE Tacna -.. Vasquez 1985

c: NADE - Tacna - valor estimado programa AQTESOLV 1985

d: INADE - Proyecto Especial Tacna

\section{CONDUTIVIDADE HIDRÁULICA (K)}

Este coeficiente foi estimado da relação entre a transmisividade e a espessura do aqüífero, que representa o fluxo de água que atravessa uma seção unitária de aqüifero, sob a influência de um gradiente unitário, na temperatura de campo. Também é conhecido como indicador da textura do aqüifero (VILLANUEVA \& IGLESIAS, 1984):

$K=\frac{T}{H}$

$T=$ Transmissividade $\mathrm{m}^{2} / \mathrm{dia}$

$H=$ Espessura do aqüifero

$K=$ Permeabilidade $\mathrm{m} / \mathrm{dia}$

TABELA 28 - CONDUTIVIDADE HIDRÁULICA DO AQÜIFFERO MAURE CAPILLUUNE .

\begin{tabular}{|c|c|c|c|c|c|c|}
\hline $\begin{array}{l}\text { Zona de } \\
\text { avaliação }\end{array}$ & $\begin{array}{c}\text { Poço de } \\
\text { bombeamento }\end{array}$ & $\begin{array}{c}\text { Poço de } \\
\text { observação }\end{array}$ & $\begin{array}{c}\text { Espessura } \\
\text { saturada }(m)\end{array}$ & $\begin{array}{l}\text { K calcula } \\
(\mathrm{m} / \mathrm{dia})\end{array}$ & $\begin{array}{c}\text { Método de } \\
\text { interpretaçäo }\end{array}$ & $\begin{array}{c}\text { Formaçäo } \\
\text { aquilfera }\end{array}$ \\
\hline Área 1 & $P A-6$ & PCA-6 & 61,00 & 32,00 & Theis & Maure \\
\hline Área 2 & PCh-ALT & & 39,00 & 11,14 & Jacob & Maure \\
\hline Área 1 & PA.5 & & 90,00 & $2,11^{\star}$ & & Capillune \\
\hline
\end{tabular}


Os resultados obtidos representam meios de alta condutividade hidráulica relacionados a aqüiferos constituídos por areias limpas e areias cascalhosas, (VILLANUEVA \& IGLESIAS Op.Cit). Esta característica guarda relação com o tipo de material do aqüiffero Maure. Quanto a formação Capillune, o valor corresponde a aqüiferos de condutividade hidráulica média.

\section{COEFICIENTE DE ARMAZENAMENTO ( $S$ )}

Este parâmetro foi estimado para o aqüifero Maure pelo método gráfico com dados do poço de observação PCA-6, seguindo a seguinte equação de Theis:

$S=\frac{4 T t u}{r^{2}}$

$S=$ Coeficiente de armazenamento.

$T=$ Transmissividade $1959,5 \mathrm{~m}^{2} /$ dia.

$t=$ Tempo $(0,001$ dias) correspondente para um rebaixamento $4 \mathrm{~m}$.

$r=$ Distância entre poço de bombeamento e poço de observação: 92,70 $\mathrm{m}$.

$1 / u=10$ valor obtido da curva padräo de Theis que corresponde a $W(u)=10$.

$S=4 \times 1959.5 \mathrm{~m}^{2} /$ dia.x.0.001dias $x .10$

$(92.70 . m)^{2}$

$S=9 \times 10^{-3}$

TABELA 29 - COEFICIENTE DE ARMAZENAMENTO DO AQUIFERO MAURE CAPILLUNE

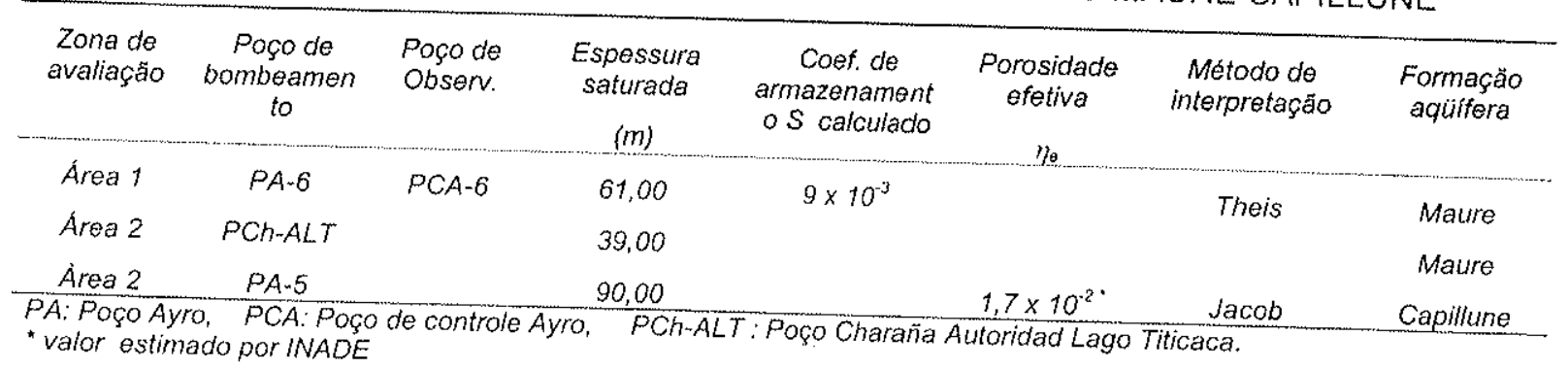

Segundo as tabelas de VILLANUEVA e IGLESIAS (1984) o valor estimado é representativo de aqüiferos semiconfinados, o que estaria corroborando as 
condições litoestruturais do aqüifero Maure, que foram caracterizadas na zona de pesquisa.

Para o aqüifero livre Capillune, por falta de condições técnicas, não foi estimado o valor de porosidade efetiva $\left(\eta_{e}\right)$. Por esta razão assume-se o valor estimado por Vasquez de INADE Tacna $=1,7 \times 10^{-2}$

\section{RAIO DE INFLUENCIA.}

$O$ raio de influência varia em função da Condutividade Hidráulica e tempo de bombeamento. $O$ valor foi estimado seguindo a seguinte equação:

$R=1,5 \sqrt{\frac{T t}{S}}$

$R=$ Raio de influência $(m)$

$T=$ Transmissividade $\left(1959,5 \mathrm{~m}^{2} /\right.$ dia $)$.

$t=$ Horas total de bombeamento (40 horas Equiv. 1,6 dias)

$S=$ Coeficiente de armazenamento $\left(9 \times 10^{-3}\right)$

Para o cálculo respectivo foi utilizado os dados do poço do bombeamento PA-6 $R=1,5 \sqrt{\frac{1959,5 \mathrm{~m}^{2} / \text { dia } .1,6 \cdot d i a}{9 \times 10^{-3}}} \quad \underline{R=885 \mathrm{~m}}$.

Para o aqüifero Capillune, segundo os dados de INADE Tacna (1985), o raio de influência é de $200 \mathrm{~m}$.

Segundo classificação feita por diversos pesquisadores, o valor estimado corresponde a aqüíferos que têm comportamento semiconfinado. Os resultados encontrados facilitará o planejamento de localização de futuras obras de captação que puderem ser implementadas nesta área.

\subsection{0.- Análise da capacidade produtiva do aqüífero}

Na TABELA 30 são apresentados dados de vazão, calculados pela empresa construtora de poços INADE, Instituto Nacional de Desarrollo- Proyecto Especial de Afianzamiento y Ampliación de los Recursos Hidricos de los Departamentos de Tacna y Moquegua. Os valores estimados correspondem às datas quando foram construídos os diferentes poços, além dos dados de vazão de produção medidos 
na fase de cadastramento realizado no ano 2001. A produção acumulada atual de seis poços atinge uma vazão de $1368 \mathrm{~m}^{3} / \mathrm{h}$.

TABELA.30 - DADOS DE VAZÃO DOS DIFERENTES POÇOS.

\begin{tabular}{|c|c|c|c|c|c|c|c|c|}
\hline Poço & $\begin{array}{c}\text { Localizaçã } \\
0 .\end{array}$ & $\begin{array}{l}\text { Prof. } \\
\text { poço. } \\
\text { (m) }\end{array}$ & $\begin{array}{c}\text { N.E } \\
M\end{array}$ & $\begin{array}{c}\text { Vazäo ótima } \\
\text { inicial } \\
\mathrm{Q}(\mathrm{m} 3 / \mathrm{h})\end{array}$ & $\begin{array}{c}\text { Vazão de } \\
\text { produção atual } \\
Q(m 3 / h)\end{array}$ & $\begin{array}{c}\text { Rebaixa- } \\
\text { mento } \\
(\mathrm{m})\end{array}$ & $\begin{array}{l}\text { Aquiferos em } \\
\text { produção }\end{array}$ & Tipo de poço \\
\hline PA-1 & Ayro- Peru & 105 & 26,91 & 244,80 & 183,6 & $38,54^{*}$ & Fluvioglac-Maure & Produção \\
\hline $\mathrm{PA}-2$ & Ayro-Peru & 150 & 7,02 & 190,80 & 111,6 & 23,94 & Capillune - Maure & Produção \\
\hline PA-3 & Ayro- Peru & 119 & 2,74 & 243,50 & 270,0 & 11,79 & Capillune - Maure & Produção \\
\hline PA-4 & Ayro-Peru & 99 & 17,28 & 280,10 & 201,6 & 41,56 & Capillune - Maure & Produção \\
\hline $\mathrm{PA}-5$ & Ayro-Peru & 90 & Jorrante & 216,60 & Poço abandonado & & Capillune & \\
\hline PA-6 & Ayro- Peru & 64 & 0,18 & 475,20 & 410,4 & 29,87 & Maure & Produçăo \\
\hline PA-7 & Ayro- Peru & 102 & Jorrante & 198,00 & Poço abandonado & & Capillune & \\
\hline PA.9 & Ayro- Peru & 133 & 14,19 & 240,12 & 129,6 & 27,13 & & Produção \\
\hline PA-10 & Ayro-Peru & & 17,68 & 183,60 & Poço de reserva & & Capillune-Mure & \\
\hline PA-11 & Ayro- Peru & & 31,32 & 144,00 & Poço abandonado & & & \\
\hline PA.12 & Ayro-Peru & & 5,01 & 295,20 & Poço de reserva & & Aluvial, Maure & \\
\hline$P A-13$ & Ayro- Peru & & 12,54 & 154,80 & Poço de reserva & & Aluvial, Maure & \\
\hline $\begin{array}{l}\text { PCH. } \\
\text { ALT }\end{array}$ & $\begin{array}{c}\text { Charaña - } \\
\text { Bolivia }\end{array}$ & 130 & 0,00 & & 39,60 & & Maure & \\
\hline
\end{tabular}

Os dados apresentados na tabela evidenciam de algum modo, a produtividade do poço e do aqüifero. Observa-se uma amplitude de variação de vazões, sendo estes dados matéria de análise neste estudo como um elemento a mais de avaliação da potencialidade produtiva do aqüífero Capillune e Maure.

$\mathrm{Na}$ análise de dados de vazões dos diferentes poços profundos em função do projeto do poço e influência da formação aqüífera no local do poço, observou-se as seguintes características:

- De quatorze poços profundos cadastrados, $72 \%$ dos poços (10 poços) apresentam um projeto com uma zona de filtros que captam águas das formações aqüiferas Capillune e Maure. Esta caracteristica dos poços não permite avaliar, com precisão e de modo individual, o comportamento e capacidade de produção específica dos aqüiferos Capillune e Maure.

- Analisando os dados de capacidade produtiva dos poços profundos apresentadas na TABELA 31, nota-se que os poços que captam águas de duas formações aqüíferas Maure e Capillune, mostram uma capacidade específica 
que varia entre $6,59 \mathrm{~m}^{3} / \mathrm{h} . \mathrm{m}$ (PA-2) a $29,83 \mathrm{~m}^{3} / \mathrm{h} . \mathrm{m}$ (PA-3) Estes valores representam a somatória do aporte de águas das duas formações aqüiferas. $O$ maior aporte de águas subterrâneas provavelmente tenha origem na Formação Maure, por suas caracteristicas semiconfinadas e fluxo ascendente. Esta hipóteses fundamenta-se na seguinte observação:

- Poço PA-6 construído dentro da formação aqüífera Maure, apresenta uma vazão ótima de $475,2 \mathrm{~m}^{3} / \mathrm{h}$, equivalente a uma capacidade específica de $13,80 \mathrm{~m}^{3} / \mathrm{h}$.m. Este valor é considerado como um valor representativo de meios semi-confinados de alta capacidade específica, corroborando as características litoestruturais do aqüifero Maure.

- O poço PCh-ALT, construído na Formação Maure, apresenta uma vazão de $39,6 \mathrm{~m}^{3} / \mathrm{h}$ com uma capacidade especifica de $8,28 \mathrm{~m}^{3} / \mathrm{h}$.m. Este valor pode estar condicionado pelo diâmetro do poço profundo ( $\phi 12 ")$, que não permitiu instalar um equipamento de bombeamento de maior capacidade.

- Poços construídos na formação Capillune (PA-5 e PA-7), segundo os dados da empresa construtora, estimaram uma vazão de $226,6 \mathrm{~m}^{3} / \mathrm{h}$ e $198 \mathrm{~m}^{3} / \mathrm{h}$, respectivamente, equivalente a uma capacidade especifica de $4,83 \mathrm{~m}^{3} / \mathrm{h} . \mathrm{m}$ e $4,38 \mathrm{~m}^{3} / \mathrm{h}$.m. Estes valores revelam uma boa capacidade deste aqüífero, embora seja menor em relação ao aqüifero Maure.

Da análise da capacidade específica dos poços em questão (FIGURA.28, p:123), os resultados revelam que a Formação Maure constitui um aqüifero de alta produtividade, com capacidade específica de aporte superior a $8 \mathrm{~m}^{3} / \mathrm{h} . \mathrm{m}$, concordante com os valores de transmissividade estimados e têm efeito de recarga sobre o aqüífero Capillune, produzindo-se um fluxo vertical ascendente.

Por outro lado, observa-se que a Formação Capillune também constitui um importante aqüífero por suas características litoestratigráficas, relações de caráter estrutural com o aqüifero Maure e boa capacidade específica. Estes resultados, correlacionados com os parâmetros de Transmisividade e Conductividade hidráulica, indicam a alta potencialidade dos aqüiferos Maure e Capillune presentes na área pesquisada. 
O exame dos valores de capacidade específica em função da distribuição espacial do aqüífero, indica uma distribuição irregular. Na zona sul, onde localizase o poço PA-3, este apresenta um valor de $29.83 \mathrm{~m}^{3} / \mathrm{h}$.m e na zona norte o poço PA-6 apresenta valor de $13,80 \mathrm{~m}^{3} / \mathrm{h} . \mathrm{m}$. De modo geral a ocorrência do aqüífero Maure na sub-bacia manifesta-se com alta capacidade produtiva, contribuindo com esta o aqüifero Capillune. As duas formações salientam-se por sua enorme potencialidade de recursos hídricos subterrâneos que possui a área de estudo.

O raio de influência do cone de rebaixamento constitui um aspecto importante que influi na capacidade produtiva do poço. Segundo a estimativa realizada no poço de bombeamento PA-6, os efeitos de bombeamento podem estender-se até 885 $\mathrm{m}$ no aqüífero Maure, e $200 \mathrm{~m}$ no aqüífero Capillune. O dado sugere que a separação entre os poços construídos dentro do aqüifero Maure não deve ser menor a $2000 \mathrm{~m}$, e no aqüifero Capillune uma distância de separação não menor de $1000 \mathrm{~m}$ por segurança com possiveis interferências. Porém, nos poços em produção atual, observa-se esta deficiência de separação entre poços PA- 6 e PA-9; PA-12 e PA-13, cuja distância de separação é menor de $1000 \mathrm{~m}$.

TABELA 31 - CAPACIDADE PRODUTIVA DOS POÇOS TUBULARES PROFUNDOS.

Sub-bacia Uchusuma - Pert., Bolivia, Chile

\begin{tabular}{|c|c|c|c|c|c|c|c|}
\hline Poço & $\begin{array}{c}\text { Vazâo otima } \\
\text { Q-1 } \\
\left(\mathrm{m}^{3} / \mathrm{h}\right)\end{array}$ & $\begin{array}{c}\text { Vazão ano } \\
2001 \\
\text { Q-2 = } \mathrm{m}^{3} / \mathrm{h}\end{array}$ & $\begin{array}{c}\text { N. Esstático } \\
\text { (m) }\end{array}$ & $\begin{array}{l}\text { Rebaixamento } \\
\text { (m) }\end{array}$ & $\begin{array}{c}\text { Rebax. N.Est. } \\
(\Delta \mathrm{m} .)\end{array}$ & $\begin{array}{c}\mathrm{Q} / \Delta \mathrm{S} \\
\left(\mathrm{m}^{3} / \mathrm{h} \cdot \mathrm{m}\right)\end{array}$ & Aqüifero \\
\hline PA-1 & 244,8 & 183,6 & 26,91 & $38,54^{*}$ & 11,63 & 15,78 & \\
\hline PA-2 & 190,8 & $1+1,6$ & 7,02 & 23,94 & 16,92 & 6,59 & \\
\hline PA-3 & 243.5 & 270,0 & 2.74 & 11.79 & 9,05 & 29,83 & \\
\hline PA-4 & 280,1 & 201,6 & 17,28 & 41,56 & 24,28 & 8,30 & \\
\hline PA-5 & 216,6 & & Jorrante & Poço abandonado & 44,81 & 4.83 & Capiliune \\
\hline PA-6 & 475,2 & 410,4 & 0,18 & 29,87 & 29,69 & 13,80 & Mure \\
\hline PA-7 & 198 & & jorrante & Poço abandonado & 45,15 & 4,38 & Capillune \\
\hline PA-9 & 240,12 & 129,6 & 14,19 & 27,13 & 12,94 & 10,00 & \\
\hline PA-10 & 183,6 & & 17,68 & & & & \\
\hline PA-11 & 111,6 & & 31,32 & & & & \\
\hline $\mathrm{PA}-12$ & 295,2 & & 5,01 & & & & \\
\hline PA-13 & 154,8 & & 12,54 & & & & \\
\hline $\begin{array}{l}\text { PCH- } \\
\text { ALT }\end{array}$ & 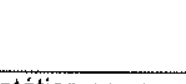 & 39,6 & 0,00 & 4,78 & 4,78 & 8,28 & Maure \\
\hline
\end{tabular}


FIGURA 28 - CAPACIDADE ESPECIFICA DE PRODUÇÃO DOS POÇOS

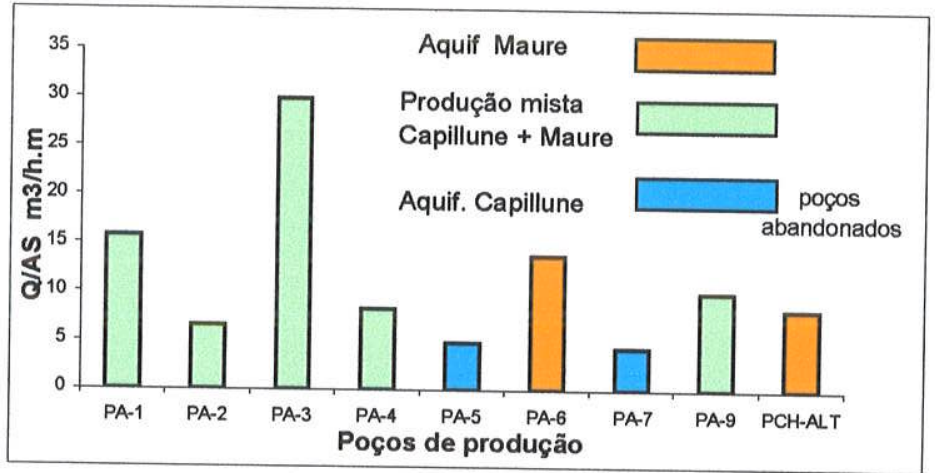

Q/AS: vazão específica $\mathrm{m}^{3} / \mathrm{h} \cdot \mathrm{m}$ 


\section{CAPITULO VIII}

\section{HIDROQUIMICA}

As águas, por sua natureza, possuem propriedades físicas e químicas que atuam sobre os materiais em contato, lixiviando ou dissolvendo seus componentes sólidos, líquidos ou gasosos. Neste processo a água adquire uma composição química variada, de acordo com as condições bio-climáticas que the conferem diferentes graus de agressividade.

Na região da Cordilheira Ocidental dos Andes, a qualidade físico-química das águas tem uma característica própria pelo tipo de material predominante nesta região, que são formações geológicas constituídas por depósitos piroclásticos, derrames de lava andesitos, riodacitos, depósitos de enxofre, boro, minerais variados e manifestações de águas hidrotermais. Por esta característica, a qualidade das águas superficiais e subterrâneas muda ao longo do deslocamento, desde suas nascentes no sentido da drenagem, pelo incremento progressivo de sais lixiviados ou dissolvidos. O nivel de concentração de seus componentes finalmente determinará a aptidão de uso para diferentes fins.

Do ponto de vista de uso, as águas da sub-bacia Uchusuma, dentro da economia do município de Tacna - Peru, constitui um recurso estratégico de primeira ordem para o desenvolvimento da economia local, fundamentalmente para a expansão da agricultura nas áreas desérticas do litoral Pacifico e industrias afins. Este interesse de uso precisa de uma qualidade apta para os fins específicos.

A qualidade das águas da sub-bacia foram avaliadas a partir de resultados da análise físico-química de duas campanhas de amostragem. O objetivo foi avaliar aspectos de variação temporal na composição química e aspectos relacionados com o tipo de material por onde escoa as águas subterrâneas. A primeira campanha de amostragem realizou-se finalizando a temporada de precipitação em abril do ano 2000, e março 2001. A segunda campanha de amostragem realizou-se na temporada de estiagem no mês de outubro do ano 2001 . O número de pontos de amostragem foi assim estabelecido: 
- Na zona do Ayro - Peru (área 1), escolheu-se doze poços tubulares profundos(TABELA 34), dos quais as águas do poço PA-6 representa a qualidade das águas da Formação aqüifera Maure. O restante dos poços fornecem uma mistura de águas das formações Capillune e Maure. Em outros poços, como o PA- 5 e PA-7, tem influência as águas hidrotermais que afloram entre o local Cruz Pujo e Huayllata, que drenam em direção à lagoa Blanca através do pequeno vale fluvial "Venada", lugar onde encontram-se os referidos poços.

- Na zona de Charaña (área 2), escolheram-se oito pontos de amostragem, (TABELA 35), cujos poços são de pouca profundidade e não ultrapassam os 14 m. Estas águas correspondem a Formação Fluviolglacial Charaña e aqüifero livre Capillune.

Os resultados das análises físico-químicas encontrados, refletem as características dos pontos da amostragem.

\subsection{0.-Características físico-químicas}

\subsection{1.- Condutividade elétrica}

Este parâmetro é uma medida do conteúdo de sais solúveis ionizados na água, que normalmente variam em função da temperatura e a força iônica (CANOVAS 1990). Com a finalidade de avaliar a variação espacial e temporal do nivel de salinidade relacionado às estações de estiagem e precipitação, realizou-se campanhas de medição semestral por um período de três anos (abril 2000 a março 2003 TABELA 32 e 33) O levantamento de dados foi realizado com instrumento digital "oakton TDS tester", que realiza correções a temperatura padronizada de $25^{\circ} \mathrm{C}$. A temperatura da água no local varia entre $11,5^{\circ} \mathrm{C}$ a $12,8^{\circ} \mathrm{C}$.

Para analisar e interpretar a variação espacial da condutividade elétrica foram elaborados dois diagramas: a FIGURAS 29 ( $p: 127)$ permite visualizar o perfil de variação na zona do Ayro - Peru (área 1) de SW-NE, e na FIGURA 30 (P:127) mostra-se o perfil de variação na zona de Charaña da Bolívia ( área 2) entre o 
poço 1 Est. Luripani e poço 10 do local Tripartito. Os diagramas mostram a seguinte característica:

- na FIGURA 29 nota-se que, entre os poços PA-7 e PA-5, localizados na zona de lagoa Blanca, e curso do vale fluvial Venada, apresenta valores altos de condutividade elétrica entre $850 \mu \mathrm{S} / \mathrm{cm}$ a $1013 \mu \mathrm{S} / \mathrm{cm}$. A alta salinidade das águas desta área relaciona-se à mistura com águas de fontes hidrotermais de natureza sulfatada que afloram na zona de Huayllata e Cruz Pujo, distante a 7 $\mathrm{Km}$ dos poços PA-7 e PA-5. Estas águas mineralizadas deslocam-se em direção a lagoa Blanca incrementando o nivel de salinidade e limitando o uso destas águas;

- na zona do rio Uchusuma, onde estão localizados os poços PA-3 e PA-1, o nivel de salinidade diminui a valores entre $450 \mu \mathrm{S} / \mathrm{cm}$ e $563 \mu \mathrm{S} / \mathrm{cm}$. Por suas características são de boa qualidade;

- nível de salinidade ainda diminui em direção $N E$ a valores entre $329 \mu \mathrm{S} / \mathrm{cm}$ a $112 \mu \mathrm{S} / \mathrm{cm}$, onde estão localizados os poços PA-10 e PA-6, PA12 e 13;

- na área 2 os valores da condutividade elétrica guardam uma semelhança com as características da área 1. O diagrama da FIGURA.30 mostra o perfil transversal da variação em direção sul e norte. Observamse que, no poço Luripani, localizado nas planícies de Visviri, zona de fronteira com o território chileno, apresenta valores entre $600 \mu \mathrm{S} / \mathrm{cm}$ e $700 \mu \mathrm{S} / \mathrm{cm}$. Estes valores diminuem em direção Norte a valores entre $100 \mu \mathrm{S} / \mathrm{cm}$ e $200 \mu \mathrm{S} / \mathrm{cm}$ como o apresentado no local Tripartito, poço 10. 
FIGURA 29 - VARIAÇÃO DE CONDUTIVIDADE ELÉTRICA, ZONA DE AYRO, PERIOODO ABRIL 2000 A MARÇO 2003

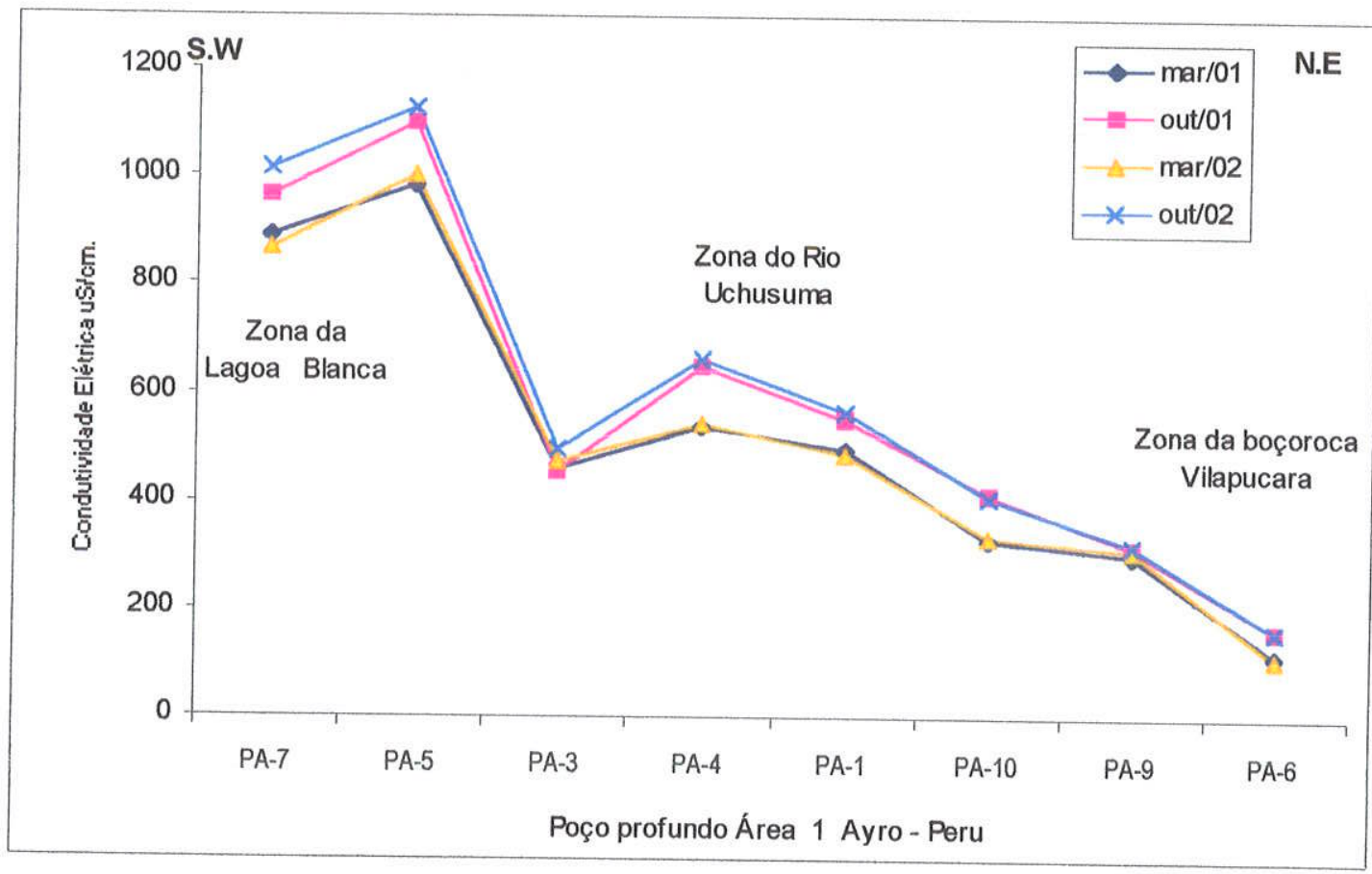

FIGURA 30 - VARIAÇÃO DE CONDUTIVIDADE ELÉTRICA, ZONA DE CHARAÑA, PERÍODO ABRIL 2000 A MARÇO 2003

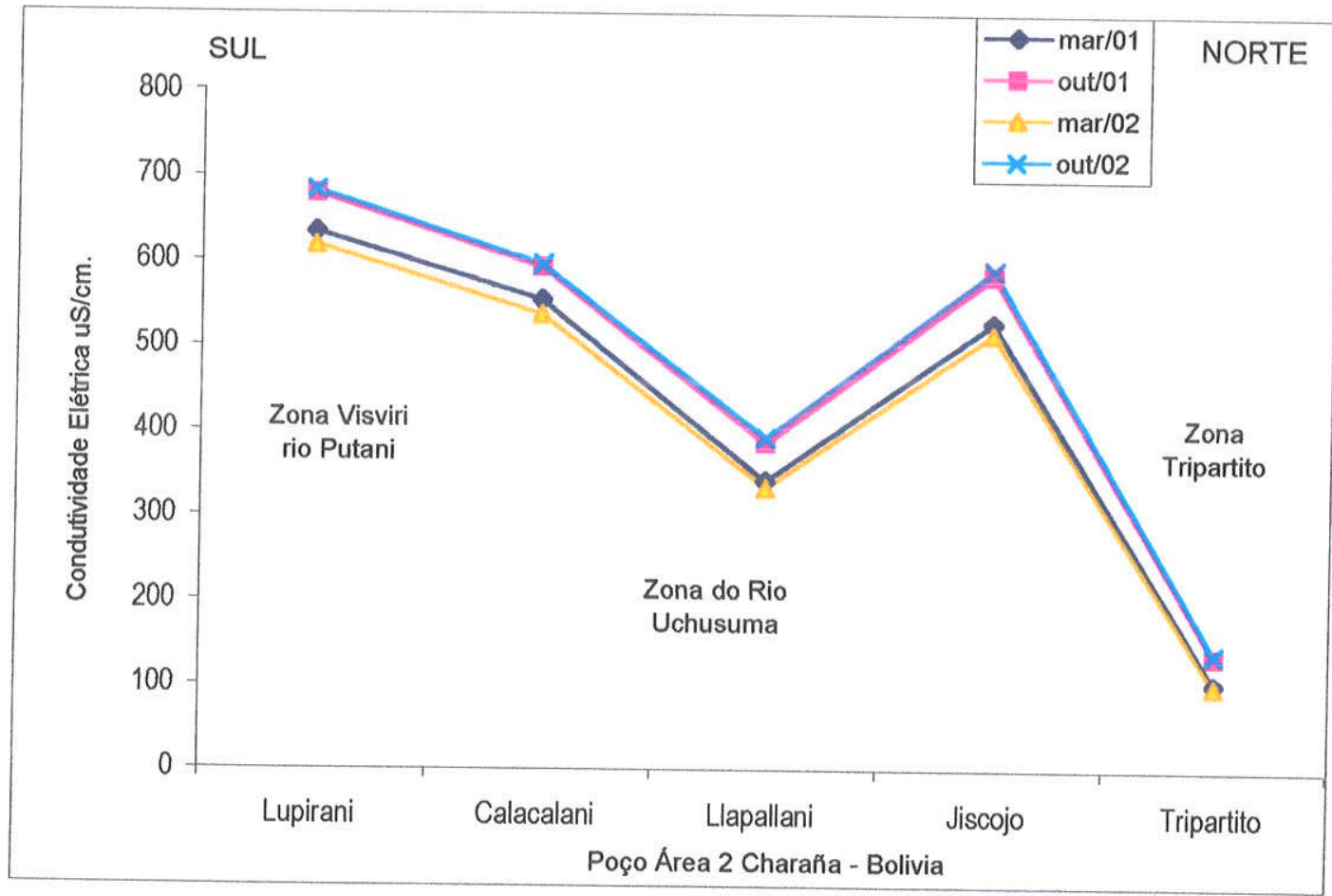

Quanto à variação temporal ligada a épocas de precipitação e estiagem, observase pequenas variações de valores de um período a outro. 
Segundo SZIKSZAY, (1993), estas mudanças estão relacionadas a maior concentração de sais dissolvidos que ocorre na época seca e, em períodos de precipitação, sofrem diluição por efeitos da chuva.

Outro parâmetro de interesse relacionado à condutividade elétrica é a Concentração de Sais Totais Dissolvidos na água (STD), calculado segundo a equação de CANOVAS (1990).

$S T D=C . E \times K \quad(28)$ onde:

$$
\begin{aligned}
& \text { STD }=\text { Concentração de sais totais dissolvidos }(p p m) \\
& \text { C.E }=\text { Condutividade elétrica mmhos } / \mathrm{cm} \\
& k \quad=\text { Constante de proporcionalidade } 0,64 \text { a } 0,70
\end{aligned}
$$

Os resultados são apresentados na TABELA 34,35. Em termos gerais, estas águas podem ser classificadas de baixa a moderada salinidade, exceto as águas do poço PA-7 e PA-5 que apresentam valores máximos de 769 ppm, relacionados à mistura de águas mineralizadas de origem hidrotermal. $O$ fenômeno de hidrotermalismo é freqüente na região da cordiheira dos Andes pela atividade do vulcanismo recente. 
TABELA 32 - PERFIL DA CONDUTIVIDADE ELETRICA, pH OBSERVADO ENTRE O PERIODO 2000 A 2003 -AYRO PERU

\begin{tabular}{|c|c|c|c|c|c|c|c|c|c|c|c|c|c|c|}
\hline \multirow{2}{*}{ Poço } & \multicolumn{2}{|c|}{$\begin{array}{c}\text { Localizaçāo } \\
\text { Coordenadas UTM }\end{array}$} & \multicolumn{6}{|c|}{ C.E $\mu S / \mathrm{cm}$} & \multicolumn{6}{|c|}{$\mathrm{Ph}$} \\
\hline & Lat. & Long. & $4 / 2000$ & $3 / 2001$ & $10 / 2001$ & $3 / 2002$ & $10 / 2002$ & $03 / 2003$ & $4 / 2000$ & $3 / 2001$ & $10 / 2001$ & $3 / 2002$ & $10 / 2002$ & $03 / 2003$ \\
\hline$P A-1$ & 8057,56 & 434,27 & 507 & 496 & 552 & 487 & 563 & 501 & 6,71 & 6,83 & 6,25 & 6,68 & 6,22 & 6.9 \\
\hline $\mathrm{PCA}-1$ & 8057,57 & 434,28 & 534 & 564 & 561 & 538 & 557 & 498 & 6,18 & 6,06 & 6,14 & 6,64 & 6,12 & 6,73 \\
\hline PA-2 & 8056,62 & 432,24 & 539 & 546 & 560 & 542 & 539 & 553 & 6,57 & 6,72 & 6,26 & 6,68 & 6,18 & 6,65 \\
\hline PA-3 & 8053,80 & 432,10 & 462 & 460 & 453 & 472 & 497 & 452 & 6,83 & 7,01 & 6,45 & 6,94 & 6.25 & 7,06 \\
\hline PCA-3 & 8054,15 & 432,30 & 458 & 489 & 502 & 469 & 486 & 462 & 6,56 & 6,33 & 6,24 & 6,71 & 6,25 & 6,94 \\
\hline PA-4 & 8055,80 & 434,15 & 547 & 539 & 649 & 542 & 662 & 552 & 6,95 & 7,01 & 6,31 & 7,05 & 6,38 & 7,06 \\
\hline$P C A-4$ & 8055.81 & 434,14 & 542 & 628 & 651 & 539 & 672 & 548 & 6,22 & 6,29 & 6,27 & 7,01 & 6,45 & 7,04 \\
\hline PA-5 & 8051,75 & 431,45 & 990 & 984 & 1098 & 1002 & 1124 & 996 & 5,13 & 5,16 & 5,26 & 5,12 & 5,14 & 5,18 \\
\hline PA-6 & 8060,79 & 434,42 & 116 & 118 & 162 & 112 & 164 & 118 & 8,28 & 8,12 & 7,86 & 8,08 & 7,89 & 8,01 \\
\hline PCA-6 & 8061,00 & 434,35 & 172 & 218 & 224 & 168 & 229 & 183 & 8,26 & 8,12 & 7,91 & 8,13 & 7,96 & 8,14 \\
\hline${ }^{*} \mathrm{PA}-7$ & 8049,78 & 429,55 & 850 & 890 & 962 & 867 & 1013 & 847 & 6,30 & 6,34 & 6,59 & 6,28 & 6,64 & 6,32 \\
\hline $\mathrm{PCA}-7^{-7}$ & 8049,85 & 429,55 & 849 & 836 & 958 & 855 & 1008 & 851 & 6,36 & 6,84 & 6,64 & 6,25 & 6,67 & 6,29 \\
\hline${ }^{*} \mathrm{PA}-9$ & 8060,28 & 434,63 & 305 & 303 & 316 & 310 & 322 & 304 & 7,27 & 7,21 & 7,49 & 7,12 & 7,51 & 7,18 \\
\hline PA-10 & 8059,07 & 434,37 & 346 & 329 & 414 & 332 & 408 & 346 & 7,14 & 7,12 & 6.58 & 7,16 & 6,48 & 7.13 \\
\hline
\end{tabular}

$\frac{\text { TABELA 33 - PERFIL DA CONDUTIVIDADE ELETRICA, pH OBSERVADO ENTRE O PERIODO } 2000 \text { A } 2003 \text {-CHARAÑA - BOLIVIA }}{\text { Localização }}$

\begin{tabular}{|c|c|c|c|c|c|c|c|c|c|c|c|c|}
\hline \multirow{2}{*}{ Poço } & \multicolumn{2}{|c|}{$\begin{array}{l}\text { Localizaçao } \\
\text { Coordenadas UTM }\end{array}$} & \multicolumn{5}{|c|}{ C.E $\mu \mathrm{S} / \mathrm{cm}$} & \multicolumn{5}{|c|}{$\mathrm{Ph}$} \\
\hline & Lat & Long. & $3 / 2001$ & $10 / 2001$ & $3 / 2002$ & $10 / 2002$ & $03 / 2003$ & $3 / 2001$ & $10 / 2001$ & $3 / 2002$ & $10 / 2002$ & $03 / 2003$ \\
\hline-1 & 8053,49 & 451,65 & 634 & 678 & 618 & 683 & 637 & 7,13 & 7,16 & 7,18 & 7,17 & 7,15 \\
\hline 2 & 8056,19 & 451,22 & 554 & 592 & 537 & 596 & 561 & 7,63 & 7,54 & 7,65 & 7,48 & 7,62 \\
\hline 4 & 8057,83 & 452,13 & 529 & 584 & 516 & 591 & 532 & 6,98 & 6,77 & 7,01 & 6,82 & 6,94 \\
\hline 6 & 8057.57 & 454,18 & 342 & 386 & 334 & 393 & 541 & 7,73 & 7,61 & 7,63 & 7,64 & 7,66 \\
\hline 7 & 8055,52 & 454,09 & 556 & 564 & 542 & 578 & 563 & 7,24 & 7,44 & 7,28 & 7,51 & 7,26 \\
\hline$\theta$ & 8055,81 & 455,16 & 694 & 746 & 676 & 761 & 687 & 6,73 & 7,79 & 6,88 & 7.76 & 7,74 \\
\hline 10 & 8065,12 & 450.49 & 104 & 136 & 101 & 140 & 110 & 6,95 & 7,18 & 6,98 & 7,16 & 7,01 \\
\hline 11 & 8055,22 & 452,89 & 496 & 539 & 485 & 548 & 491 & 7,26 & 7,46 & 7.29 & 7,37 & 7,18 \\
\hline
\end{tabular}


TABELA 34 - RESULTADOS DE ANÁLISES FISICO-QUIMICAS DE ÁGUAS, AMOSTRADOS NA ZONA DO AYRO - PERU

\begin{tabular}{|c|c|c|c|c|c|c|c|c|c|c|c|c|c|c|c|c|c|c|}
\hline \multirow{2}{*}{ Poço } & \multirow{2}{*}{$\begin{array}{c}\text { Data de } \\
\text { amostrag } \\
\text { em }\end{array}$} & \multirow{2}{*}{$\begin{array}{c}\text { C.E } \\
\mu \mathrm{S} / \mathrm{cm}\end{array}$} & \multirow{2}{*}{${ }^{\mathrm{T}}$} & \multirow{2}{*}{$\mathrm{PH}$} & \multicolumn{2}{|c|}{ CATIONS } & \multicolumn{2}{|c|}{$($ meq/i) } & \multicolumn{3}{|c|}{ ÂNIONS (meq/) } & \multirow{2}{*}{$\begin{array}{l}\text { Boro } \\
\text { ppm }\end{array}$} & \multirow[b]{2}{*}{ SAR } & \multirow{2}{*}{$\begin{array}{l}\text { STD } \\
\text { ppm. }\end{array}$} & \multirow{2}{*}{$\begin{array}{c}\text { Dureza } \\
\text { total } \\
\text { ppm } \\
\mathrm{CaCO}_{3}\end{array}$} & \multicolumn{3}{|c|}{ CLASSIFICAÇĀO } \\
\hline & & & & & $\mathrm{Ca}^{+*}$ & $\mathrm{Mg}^{+*}$ & $\mathrm{Na}^{+}$ & $K^{*}$ & $\mathrm{Cr}$ & $\mathrm{SO}_{4}=$ & $\mathrm{HCO}_{3}{ }^{-}$ & & & & & Geoquimica & $\begin{array}{c}\text { Potabilida } \\
\text { de }\end{array}$ & $\begin{array}{l}\text { Irrigaç } \\
\text { âo }\end{array}$ \\
\hline PA-1 & $8 / 91$ & 492 & & 7,74 & 2,04 & 1,17 & 1,08 & 0,10 & 0,42 & 1,69 & 3.22 & & 0,85 & & 187.50 & Bicarb. Calcica & Boa & $\mathrm{C} 2, \mathrm{~S} 1$ \\
\hline$* *$ & $4 / 00$ & 507 & 12.3 & 6,71 & 1,07 & 2,01 & 0,95 & 0,05 & 0,40 & 1,09 & 9,44 & 0,49 & 0,77 & 354,9 & 154,29 & Bicarb. Magnes. & Boa & $\mathrm{C} 2, \mathrm{~S} 1$ \\
\hline$* *$ & $10 / 2001$ & 552 & 12,8 & 6,25 & 1,26 & 1,98 & 2,19 & 0,19 & 0,69 & 1,36 & 3,44 & & 1,72 & 386,4 & 162,29 & Bicarb. Sódica & Boa & $\mathrm{C} 2, \mathrm{S1}$ \\
\hline${ }^{* * P C A}-1$ & $3 / 2001$ & 564 & 12,6 & 6,06 & 1,04 & 1,85 & 2,68 & 0,16 & 0,66 & 1,72 & 3,39 & & 2,23 & 394,8 & 144,75 & Bicarb. Sódica & Boa & $\mathrm{C} 2 . \mathrm{S} 1$ \\
\hline ×PA-2 & $8 / 91$ & 592 & & 8,71 & 2,4 & 2,12 & 0,88 & 0,04 & 0,50 & 1,40 & 9,85 & 0,18 & 0,59 & 414,4 & 226,00 & Bicarb.cálcica & Boa & $\mathrm{C} 2, \mathrm{~S} 1$ \\
\hline$* *$ & $4 / 00$ & 539 & 12,1 & 6,57 & 2,36 & 2,27 & 0,77 & 0,03 & 0,60 & 1,89 & 3,87 & 0,18 & 0,51 & 377,3 & 231,95 & Bicarb.cálcica & $80 a$ & $\mathrm{C} 2, \mathrm{~S} 1$ \\
\hline$\star *$ & $10 / 2001$ & 560 & 11,9 & 6,26 & 2,78 & 2,45 & 1,22 & 0,16 & 0,35 & 2,30 & 4.07 & & 0,75 & 392,0 & 262,00 & Bicarb.cálcica & Boa & $\mathrm{C} 2 \mathrm{~S} 1$ \\
\hline$* P A-3$ & $8 / 91$ & 513 & & 7,74 & 3,49 & 2,99 & 0,23 & 0,02 &, 99 & 2,10 & 3,22 & & 0,12 & & 221 & Bicarb.cálcica & Boa & $\mathrm{C} 2, \mathrm{~S} 1$ \\
\hline$* *$ & $4 / 00$ & 462 & 12,16 & 6,83 & $\{, 69$ & 2,18 & 0,75 & 0,03 & 0,30 & 1,83 & 3,08 & 0,34 & 0,54 & 0,53 & 193 & Bicarb.magnes. & Boa & $\mathrm{C} 2, \mathrm{~S} 1$ \\
\hline$* *$ & $10 / 2001$ & 453 & 12,1 & 6,45 & 1,95 & 1,73 & 1,28 & 0,14 & 0,19 & 2,07 & 3,05 & & 0,84 & 317.1 & 104,31 & Bicarb.cálcica & Boa & $\mathrm{C} 2, \mathrm{~S} 1$ \\
\hline$*{ }^{*} \mathrm{CA}-3$ & $3 / 2001$ & 489 & 12,2 & 6,33 & 1,55 & 1,74 & 1,86 & 0,19 & 0,58 & 2,04 & 2,76 & & 1.45 & 342,3 & 164,78 & Bicarb.sódica & Boa & $\mathrm{C} 2, \mathrm{~S} 1$ \\
\hline PA-4 & $8 / 91$ & 700 & & 6,20 & 2,20 & 2,06 & 2,74 & 0,09 & 0,55 & 2,26 & 3,47 & 0,001 & 1,88 & & 213 & Bicarb.sódica & Boa & $\mathrm{C} 2, \mathrm{~S} 1$ \\
\hline$\star *$ & $4 / 00$ & 547 & 12,6 & 6,95 & 1.97 & 2,01 & 1,48 & 0,06 & 0,50 & 2,24 & 9,30 & 0,48 & 1,05 & 382,9 & 199,36 & Bicarb.magnes. & Boa & $\mathrm{C} 2, \mathrm{~S} 1$ \\
\hline$\star *$ & $10 / 2001$ & 649 & 12,4 & 6,31 & 1,29 & 2,21 & 2,69 & 0,12 & 0,78 & 2,36 & 3,42 & & 2,03 & 454 & 272,25 & Bicarb.sódica & Boa & $\mathrm{C} 2, \mathrm{~S} 1$ \\
\hline${ }^{\star * P C A}-4$ & $3 / 2001$ & 628 & 12,7 & 6,29 & 1,55 & 2,18 & 2,45 & 0,14 & 0,77 & 2,17 & 3,23 & & 1,79 & 439,6 & 186,83 & Bicarb.sódica & Boa & $\mathrm{C} 2, \mathrm{~S} 1$ \\
\hline${ }^{\star} \mathrm{PA}-5$ & $8 / 91$ & 1108 & & 6,17 & 3,98 & 3,32 & 6,18 & 0,18 & 0,99 & 2,80 & 7,53 & & 3,23 & & 368 & Bicarb.sódica & Má & c3s1 \\
\hline$\star \star$ & $4 / 00$ & 990 & 12.9 & 5,13 & 3,17 & 3,25 & 3,48 & 0,11 & 1,49 & 2,53 & 6,77 & 1,21 & 1,94 & 693 & 321,62 & Bicarb.sódica & Má & C3St \\
\hline 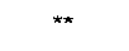 & $10 / 2001$ & 1098 & 13,4 & 5,26 & 4,19 & 2,72 & 3,38 & 0,68 & 1,24 & 2,21 & 7,41 & & 1,82 & 768,6 & 346,14 & Bicarb.cálcica & Má & c3st \\
\hline *PA-6 & $8 / 91$ & 116 & & 7,84 & 0,39 & 0,34 & 0,43 & 0,09 & 0,17 & 0,30 & 0,94 & & 0,71 & & 36,5 & Bicarb.sódica & Boa & C1S1 \\
\hline \multirow[t]{2}{*}{$* *$} & $4 / 00$ & 116 & 12,6 & 8,28 & 0,33 & 0,53 & 0,30 & 0,05 & 0,20 & 0,24 & 0,93 & 0,02 & 0,46 & 81,20 & 43,05 & Bicarb.magnes. & Boa & C1s1 \\
\hline & $10 / 2001$ & 162 & 12,3 & 7,86 & 0,61 & 0,38 & 0,36 & 0,08 & 0,08 & 0,39 & 1,01 & & 0,51 & 113,4 & 49,58 & Bicarb.cálcica & Boa & C\{S1 \\
\hline$*$ *PA 6 & $3 / 2001$ & 218 & 12,1 & 8,12 & 0,58 & 0,48 & 1,08 & 0,16 & 0,58 & 0,56 & 1,11 & & 1,48 & 152,6 & 53,06 & Bicarb.sódica & Boa & Cist \\
\hline${ }^{*} \mathrm{PA} ; 7$ & $8 / 91$ & 980 & & 6,64 & 9,26 & 9,00 & 9,54 & 3,5 & 0,60 & 6,43 & 2,22 & & 3,1 & & 919 & Sulfataómagnes. & Mediocre & C3S1 \\
\hline$\star \star$ & $4 / 00$ & 850 & 12,6 & 6,30 & 3,22 & 3,26 & 1,92 & 0,68 & 0,38 & 6,30 & 2,58 & & 1,07 & 595,0 & 324 & Sulfatad.magnes. & Mediocre & $\mathrm{C} 2, \mathrm{~S} 1$ \\
\hline$\star \star *$ & $10 / 2001$ & 962 & 12,8 & 6,59 & 3,21 & 2,71 & 2,58 & 0,94 & 0,49 & 6,13 & 2,13 & & 1,49 & 673,4 & 296,55 & Sulfatada cálcica & Mediocre & C3S1 \\
\hline${ }^{\star \star P C A}-7$ & $3 / 2001$ & 836 & 12,5 & 6,84 & 2,86 & 2,58 & 2,46 & 0,61 & 0,71 & 6,14 & 1,83 & & 1,49 & 585,2 & 272,51 & Sulfatada cálcica & Mediacre & C3S1 \\
\hline ×PA-9 & $8 / 91$ & 209 & & 8,04 & 0,77 & 0,59 & 0,79 & 0,09 & 0,28 & 0,66 & 1,04 & 0,00 & 0,98 & & 65 & Bicarb. Sódica & Boa & $\mathrm{C}_{2} \mathrm{~S} 1$ \\
\hline$* *$ & $4 / 00$ & 305 & 12,6 & 7,27 & 1,04 & 1,43 & 0,50 & 0,06 & 0,30 & 0,94 & 2,12 & 0,18 & 0,52 & 213,5 & 122,80 & Bicarb.magnes. & Boa & $\mathrm{C} 2, \mathrm{~S} 1$ \\
\hline$\star *$ & $10 / 2001$ & 316 & 12,4 & 7,49 & 1,12 & 1,52 & 0,52 & 0,12 & 0,33 & 1,05 & 2,16 & & 0,45 & 221,2 & 132,23 & Bicarb.magnes. & Boa & $\mathrm{C} 2, \mathrm{~S} 1$ \\
\hline${ }^{\star \star} \mathrm{PA}-10$ & $10 / 2001$ & 414 & 12,1 & 6,58 & 2,14 & 1,78 & 3,29 & 0,26 & 1,44 & 1,52 & 5,09 & & 2,35 & 289,8 & 196,35 & Bicarb. cálcica & Boa & $\mathrm{C} 2, \mathrm{~S} 1$ \\
\hline
\end{tabular}


TABELA 35 - RESULTADOS DE ANÁLISES FÍSICO-QUIMICAS DE ÁGUAS, AMOSTRADOS NA ZONA DE CHARAÑA BOLIVIA (ÁREA 2)

\begin{tabular}{|c|c|c|c|c|c|c|c|c|c|c|c|c|c|c|c|c|c|c|}
\hline \multirow{2}{*}{ Poço } & \multirow{2}{*}{$\begin{array}{c}\text { Data de } \\
\text { amostrag } \\
\text { em }\end{array}$} & \multirow{2}{*}{$\underset{\mu \mathrm{S} / \mathrm{cm}}{C . E}$} & \multirow{2}{*}{$\begin{array}{c}\mathrm{T} \\
{ }^{\circ} \mathrm{C}\end{array}$} & \multirow{2}{*}{$\mathrm{PH}$} & \multicolumn{2}{|c|}{ CATIONS } & \multicolumn{2}{|c|}{$($ meq/l) } & \multicolumn{4}{|c|}{ ÃNIONS (meq/l) } & \multirow[b]{2}{*}{ SAR } & \multirow{2}{*}{$\begin{array}{l}\text { STD } \\
\text { ppm. }\end{array}$} & \multirow{2}{*}{$\begin{array}{c}\text { Dureza } \\
\text { total } \\
\mathrm{ppm} \\
\mathrm{CaCO}_{3}\end{array}$} & \multicolumn{3}{|c|}{ CLASSIFICAÇĀO } \\
\hline & & & & & $\mathrm{Ca}^{+*}$ & $\mathrm{Mg}^{++}$ & $\mathrm{Na}^{+}$ & $K^{+}$ & $\mathrm{Cr}^{-}$ & $\mathrm{SO}_{4}{ }^{2}$ & $\mathrm{HCO}_{3}$ & $\mathrm{CO}_{3}=$ & & & & Geoquimica & $\begin{array}{l}\text { Potabilid } \\
\text { ade }\end{array}$ & $\begin{array}{c}\text { irrigaçã } \\
0\end{array}$ \\
\hline $1^{*}$ & $03 / 2001$ & 634 & 12,4 & 7,13 & 3,48 & 1,91 & 1.88 & 0,13 & 1,26 & 2,80 & 2,30 & & 1,14 & 443.8 & 269,99 & Sulfatada Cálcica & Boa & $\mathrm{C} 2 \mathrm{S1}$ \\
\hline $1^{\star \star}$ & $10 / 2001$ & 678 & 11.6 & 7,16 & 3,52 & 1,93 & 1,91 & 0,14 & 1,29 & 2,96 & 2,37 & & 1,15 & 474,6 & 273,00 & Sulfatada Cálcica & Boa & C2S1 \\
\hline $2^{*}$ & $03 / 2001$ & 554 & 12,3 & 7,63 & 2,21 & 1,37 & 2,16 & 0,28 & 1,02 & 2,42 & 1,71 & & 1,62 & 387,8 & 179,29 & Sulfatada Cálcica & Boa & $\mathrm{C}_{2} \mathrm{~S} 1$ \\
\hline $2^{* *}$ & $10 / 2001$ & 592 & 11,8 & 7,54 & 2,22 & 1,38 & 2,18 & 0,30 & 1,12 & 2,46 & 1,78 & & 1,62 & 414.4 & 180,33 & Sulfatada Cálcica & Boa & C2S1 \\
\hline $4^{*}$ & $03 / 2001$ & 529 & 12,4 & 6,98 & 2,46 & 1,33 & 1,04 & 0.32 & 0,62 & 1,48 & 2,11 & & 0,76 & 370,3 & 189,84 & Bicarb. Cálicica & Passável & $\mathrm{C} 2 \mathrm{~S} 1$ \\
\hline $4^{* *}$ & $10 / 2001$ & 584 & 11,6 & 6,77 & 2,50 & 1,38 & $1,12,5$ & 0,36 & 0,71 & 1,54 & 2,19 & & 0,78 & 408,8 & 194,38 & Bicarb. Cálcica & passável & $\mathrm{C} 2 \mathrm{S1}$ \\
\hline $6^{*}$ & $03 / 2001$ & 342 & 12,6 & 7,73 & 1,61 & 0,94 & 1,13 & 0,22 & 0,47 & 1,02 & 2,16 & & 5.56 & 239.4 & 127,74 & Bicarb. Cálcica & Boa & C2S1 \\
\hline $6^{\pi *}$ & $10 / 2001$ & 386 & 12,9 & 7,61 & 1,62 & 0,96 & 1,15 & 0,24 & 0,49 & 1,06 & 1,8 & & 1,01 & 270,2 & 129,23 & Bicarb. Cálcica & Bca & C2S1 \\
\hline $7^{\star}$ & $03 / 2001$ & 556 & 12,2 & 7,24 & 2,24 & 1,39 & 2,00 & 0,29 & 0,76 & 2,45 & 1,7 & & 1,48 & 389,2 & 181,83 & Sulfatada Cálcica & Boa & $\mathrm{C} 2 \mathrm{S1}$ \\
\hline $7^{\star *}$ & $10 / 2001$ & 564 & 12,8 & 7,44 & 2,28 & 1,41 & 2,08 & 0,31 & 0.79 & 2,51 & 1,8 & & 1,53 & 394,8 & 184,84 & Sulfatada Cälcica & Boa & C2S1 \\
\hline $9^{*}$ & $03 / 2001$ & 694 & 12,0 & 6,73 & 5,46 & 1,38 & 2,38 & 0,26 & 1,24 & 4,86 & 2.27 & & 1.28 & 485,8 & 342,65 & Sulfatada Cálcica & Boa & C2St \\
\hline $9^{* *}$ & $10 / 2001$ & 746 & 11,9 & 7,79 & 5,49 & 1,40 & 2,41 & 0,30 & $\uparrow, 25$ & 4,92 & 2,31 & & 1,28 & 522,2 & 345.14 & Sulfatada Cáłcica & Boa & C2S1 \\
\hline $10^{*}$ & $03 / 2001$ & 104 & 12,3 & 6,95 & 0,66 & 0,17 & 0,45 & 0,18 & 0,11 & 0,22 & 0,91 & & 0.69 & 73,0 & 41,53 & Bicarb. Cálcica & Boa & C1S1 \\
\hline $10^{\star \star}$ & $10 / 2001$ & 136 & 12,6 & 7,18 & 0,68 & 0,24 & 0,48 & 0.22 & 0,13 & 0,24 & 1,01 & & 0,70 & 95,2 & 46,04 & Bicarb. Calcica & Boa & CIS1 \\
\hline $11^{*}$ & $03 / 2001$ & 496 & 11,7 & 7,26 & 2,70 & 1.74 & 1,93 & 0,28 & 0,94 & 2,39 & 2,47 & & 1,29 & 347,2 & 222,38 & Bicarb. Cálcica & Boa & $\mathrm{C} 2 \mathrm{~S} 1$ \\
\hline $11^{\text {* }}$ & $10 / 2001$ & 539 & 12,4 & 7.46 & 2,74 & 1,81 & 2,06 & 0,36 & 1,02 & 2,42 & 2,56 & & 1,36 & 377,3 & 227,95 & Bicarb. Cálcica & Boa & $\mathrm{C}_{2} \mathrm{~S}_{1}$ \\
\hline
\end{tabular}

1.- Lupirani 2.- Est. Calacalani 4.- Est. Jiscojo 6.- Est. Llapallapani 7.. Est. Agua Rica 9. Estório de Centro de Pesquisas de Aguas Subterrâneas - Instituto de Geociências USP. 


\subsection{2.- $\mathrm{pH}$.}

Nas TABELA 32, 33 apresenta-se dados semestrais de $\mathrm{pH}$ medidos no local de amostragem durante o período 2000 a 2003. A variação espacial e temporal deste parâmetro apresenta-se nas FIGURAS 31 e 32.

De modo geral observa-se que, em épocas de estiagem, as águas tornam-se levemente ácidas e, em épocas de precipitação, adotam valores neutros devido a diluição do nível de concentração.

Quanto a variação espacial, na zona do Ayro -Peru (área 1), observa-se que, no entorno dos poços PA-7 e PA-5, as águas são de tendência ácida e sulfatadas, com alto conteúdo de sais dissolvidos pela mistura com águas de origem hidrotermal, característica esta que foi descrita no item anterior. Em direção noreste, zona do rio Uchusuma, as águas são de natureza neutra a levemente ácidas. Na zona da boçoroca Vilapucara, entre os PA-9 , PA-6 e PA-13, são de tendência alcalina, evidenciando águas de caracter alcalino.

Na área 2 de Charaña, Bolívia, as águas são de natureza neutra, que caracterizam a qualidade das águas do aqüífero livre. Observa-se que os valores de $\mathrm{pH}$ na zona Sul variam entre 7,2 a 7,8 . Estes valores diminuem até águas de natureza neutra, em direção norte (poço 10) do local Tripartito.

FIGURA 31 - VARIAÇÃO DE PH NA ZONA DO AYRO PERU (ÁREA 1)

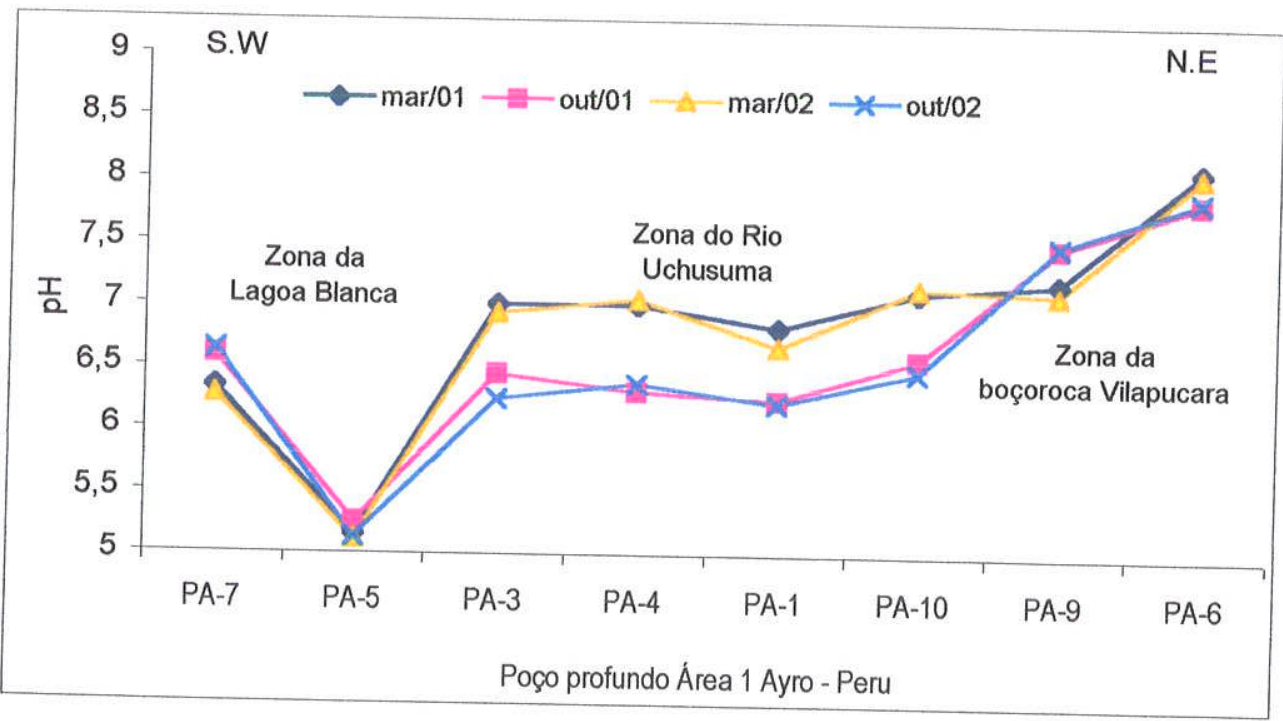


FIGURA 32 - VARIAÇÃO DE PH NA ZONA DE CHARAÑA (ÁREA 2)

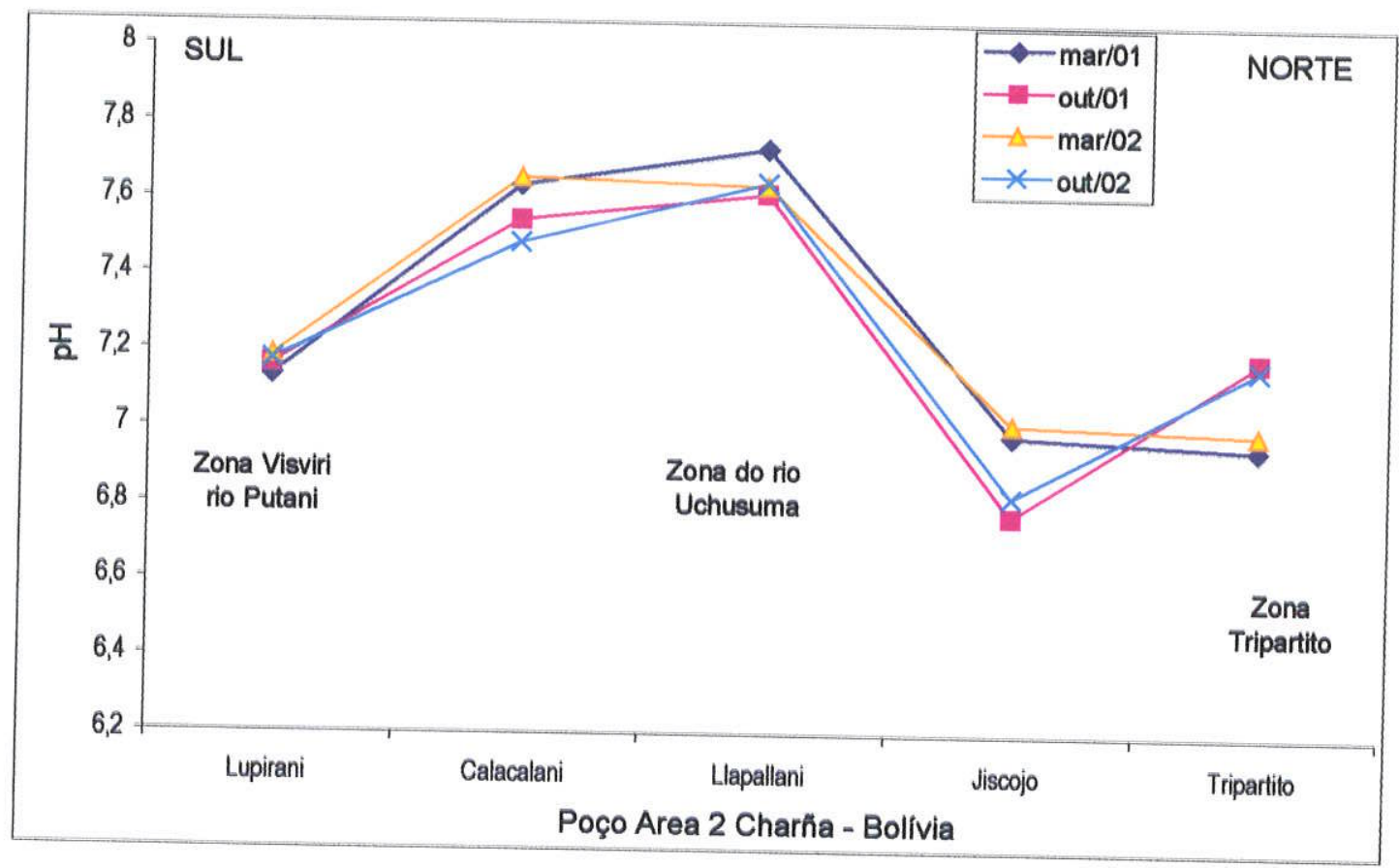

\subsection{3.- Dureza.}

No cálculo da Dureza Total (DT) foi utilizado a equação de CANOVAS, (1990).

$$
\begin{aligned}
D T(p p m)= & 2.5(\text { Ca ppm })+4.12(\mathrm{Mg} \mathrm{ppm}) \quad \text { (29) onde } \\
D T & =\text { Dureza Total } \\
C a & =\text { Cálcio } \\
\mathrm{Mg} & =\text { Magnésio }
\end{aligned}
$$

$\mathrm{Na}$ TABELA 34 e 35 apresentam-se os valores calculados deste parâmetro, que permite classificar as águas pelo tipo de dureza. Os resultados mostram as seguinte características:

- as águas do aqüífero Maure coletadas no poço PA-6 apresentam os valores mais baixos, variando entre 36,5 ppm a 49,58 ppm, que evidência águas de baixa dureza segundo a classificação de CUSTODIO (1996). 
- o restante dos poços da zona do Ayro são de dureza intermediaria a águas muito duras, seus valores variam entre 200 ppm a 346 ppm, determinados nos poços PA-5 e PA-7, respectivamente,

- na área 2, segundo os valores calculados, foram classificados como águas de dureza intermediaria, exceto as águas do poço 10, do local Tripartito, que são de águas de baixa dureza.

\subsection{0.- Qualidade química das águas}

Para as considerações de avaliação de qualidade das águas subterrâneas, as amostras de poços tubulares profundos da zona do Ayro e amostras de poços de monitoração da zona de Charaña foram analisadas nos laboratórios da "Facultad de Química de la Universidad Nacional del Altiplano de Puno," determinando-se por elementos maiores. Quanto uma parte das amostras da zona de Charaña, no Centro de Pesquisa de Aguas subterrâneas CEPAS - USP. Uma visão sucinta das suas características quimicas são apresentadas nas TABELAS 34 e 35 . Evidenciam uma forte tendência de predomínio de águas bicarbonatadas cálcicas na zona do Ayro e ocorrência pontual de águas sulfatadas no poço PA-7, que está ligado a uma mistura com águas mineralizadas de fontes hidrotermais da zona de Huayllata e Cruz Pujo.

A composição determinada têm ampla relação com a natureza química dos derrames andesiticos, piroclásticos e camadas de calcários, nas quais a distribuição dos óxidos nas rochas, como o oxido de cálcio, é predominante sobre o sódio e magnésio.

Segundo os resultados obtidos, na zona do Ayro-Peru (área 1) ocorrem em áreas específicas, águas de diferente composição química, devido a uma mistura de fluxo dos aqüiferos Maure e Capillune:

- entre os poços PA-7 e PA-5 temos águas sulfatadas magnésianas, com tendência sódica e bicarbonatada calcica, de baixa qualidade por seu alto conteúdo de STD (máximo 769 ppm, mínimo 693 ppm), que ultrapassam os limites permissiveis de $500 \mathrm{mg} / \mathrm{L}$ das normas da OMS, e contém presença de Boro 1,21 mg/L, 
- a qualidade das águas dos poços PA-3, PA-2, PA-4 e PA-1, representam uma mistura de fluxos de águas do aqüifero Capillune e Maure, observando-se uma baixa mineralização e certa predominância de bicarbonatos,

- em direção NE as águas dos poços PA-6, PA-9 são representativas do aqüifero Maure, e apresentam baixa concentração de ions de $\mathrm{Ca}, \mathrm{Mg}, \mathrm{Na}, \mathrm{Cl}$, $\mathrm{SO} 4$ e HCO3 menores que 1,5 meq/L. Estas características qualificam como águas de boa qualidade para diversos usos.

$\mathrm{Na}$ zona de Charaña (área 2) as águas amostradas correspondem ao aqüífero livre da Formação Charaña. Na composição química observa-se um predomínio de ions de sulfato e cálcio. Em lugares pontuais ocorrem águas de composição bicarbonatada cálcica, como em Jiscojo, Llapallapani, Tripartito e Charaña. A qualidade destas águas é representativa da Formação Charaña.

A notória diferença na composição química das águas está relacionado a uma mistura de fluxos locais e regionais, que entram em contato com sedimentos vulcânicos e fontes hidrotermais que ocorrem nesta área. A Instituição Autoridad del Lago Titicaca ALT, Bolívia em 1998, realizarou trabalhos de caracterização de águas a nivel da bacia do rio Maure, onde evidenciaram a ocorrência de Arsênio (As) proveniente de fontes hidrotermais.

No sul do Peru, o hidrotermalismo é fonte potencial de contaminação natural de águas superficiais e subterrâneas, e isto evidencia-se nos trabalhos desenvolvidos por STEINMULLER \& ZAVALA (1997). Estudos anteriores realizados nas planícies de Callapuma, zona próxima a sub-bacia Uchusuma, por IMGEMMET (1995), salientam que, em zonas de mineralização com Boro e fontes hidrotermais, o conteúdo de "As" apresentamse em concentrações entre 10,4 mg/L a $19,6 \mathrm{mg} / \mathrm{L}$. Estes valores que, por efeito de diluição de épocas de precipitação, diminuem para concentrações de $2,5 \mathrm{mg} / \mathrm{L}$. A ocorrência de arsênio, está relacionado a lixiviação de minerais de sulfuro de arsênio como ouro-pigmento $\left(\mathrm{As}_{2} \mathrm{~S}_{3}\right)$, arsenopirita $\mathrm{Fe}(\mathrm{AsS})$ e realgar (AsS) em área de manifestação hidrotermal; geralmente estes minerais apresentam-se nas cavidades de lavas porosas como produto de sublimação associada ao enxofre 


\subsection{0.- Classificação das águas.}

\subsection{1.- Classificação segundo os íons dominantes.}

Nas TABELAS 34, e 35 temos uma classificação geoquímica segundo os íons dominantes das águas amostradas nos diferentes poços da área de pesquisa.

A classificação geoquimíca foi feita utilizando o diagrama de PIPER, que emprega como parâmetros principais de classificação a concentração dos elementos maiores em porcentagem, não representando as concentrações absolutas dos íons considerados.

- Na figura 33 observa-se que as águas da zona do Ayro apresentam concentração dos elementos maiores dentro do tipo Bicarbonatada, variando entre cálcica e magnésica. Porém, as águas da zona de Charaña, mostram uma concentração dos ions no limite de água sulfatada cálcica, variando a bicarbonatada cálcica

FIGURA 33 - CLASSIFICAÇÃO HIDROGEOQUIMICA DAS ÁGUAS, MÉTODO DE DIAGRAMA DE PIPER
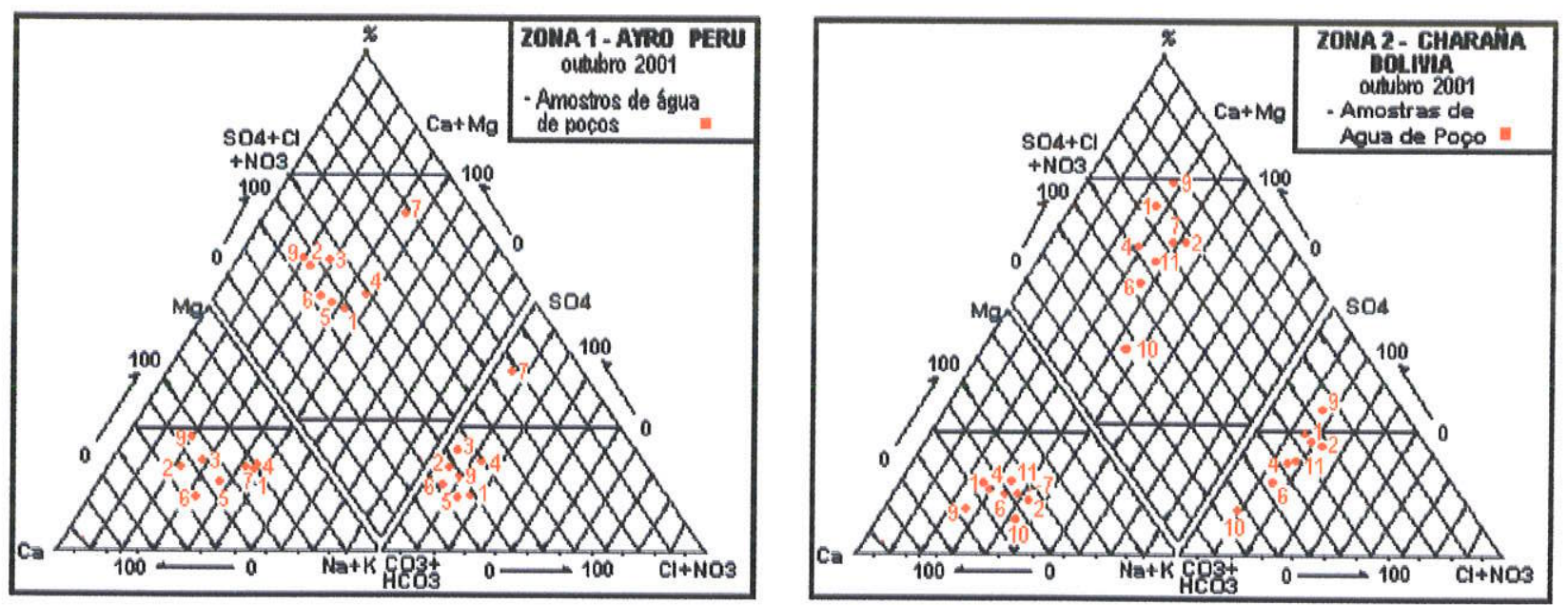

\subsection{2.- Qualidade da água para irrigação}

Segundo CANOVAS (1990) as águas para irrigação são classificadas pelo grau do efeito com que agem as concentrações dos íons da água sobre as culturas e solo. Os limites toleráveis para o uso são admitidos segundo as normas recomendadas pelo "US Department of Agriculture", que são de ampla utilização. 
O parâmetro que define a qualidade de água para irrigaçâo é o índice de conservação de solos, ou "Sodium Absorption Ratio" (SAR). Segundo HOUNSLOW (1995), este índice é uma medida do grau em que o sódio presente na água substitui o $\mathrm{Ca}^{2+}+\mathrm{Mg}^{2+}$ de solos argilosos, quando este é adsorvido. Se o valor do índice for superior a 10, considera-se perigoso para a estrutura do solo, pelo efeito degradador do sódio.

As amostras, segundo os índices estimados de (SAR), mostram valores baixos de 0,12 e um valor máximo de 2,35 evidenciando-se que não existe perigo de alcalinização do solo.

Além do índice estimado, as águas de irrigação são classificadas pela dureza de salinidade (condutividade ou STD) e dureza de sódio (SAR), segundo as normas Riverside (U.S Soil Salinity Laboratory) (CANOVAS, 1990). Estes dois parâmetros, no diagrama de classificação de águas, estão relacionados, representando-se a salinidade por (C), e o sódio por (S). A maior ou menor concentração dos componentes são indicados por um sub-índice numérico que varia de 1 a 4 . Estes valores permitem que a água seja classificada com anotações Ci Sj. Os subindices maiores que 2 representam má qualidade da água.

Na FIGURA 34 observa-se que as amostras analisadas em maior porcentagem são de qualidade C2-S1 (Baixo sódio, salinidade media). O uso destas águas precisa de lavagem da crosta salina que tende a formar-se na superficie do solo. C3-S1 (Baixo sódio e salinidade alta) por sua alta salinidade não podem ser utilizados em solos cuja drenagem seja deficiente; C1-S1 (baixo sódio e baixa salinidade) são águas aptas para irrigação. De modo geral estas águas são apropriadas para irrigação. 
FIGURA 34 - CLASSIFICAÇÃO DE ÁGUAS PARA IRRIGAÇÃO

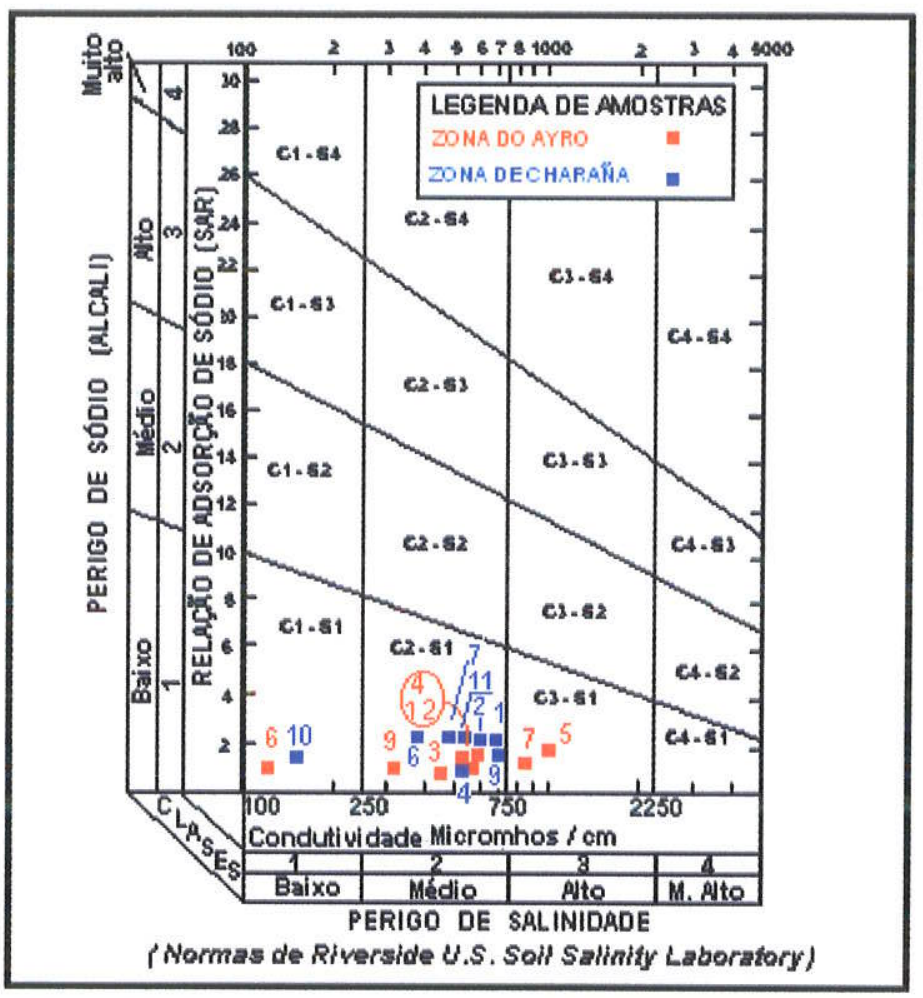

\subsection{3.- Qualidade da água para o consumo humano.}

Considera-se, como padrão de potabilidade de água, as normas estabelecidas pela "Organização Mundial de Saúde" (OMS, 1963) International Standards for Drinking - Water, que fixam as características da qualidade da água para o consumo humano, estabelecendo limites aceitáveis dos diversos elementos presentes na água.

Alem do indicado, existem outras normas internacionais de controle de qualidade tais como: USEPA (1980) para substancias tóxicos, USPHS (United States Public Health Service), normas peruanas e bolivianas de controle de qualidade das águas. Estas foram utilizadas para estabelecer nivel de potabilidade (TABELA 37).

Para uma determinada área geográfica, o uso da água depende, principalmente, da disponibilidade local dos recursos hídricos, das variações climáticas e do custo da oportunidade ou de produção. As água da sub-bacia Uchusuma são explotadas para abastecer o município de Tacna, localizado no litoral Pacífico de clima árido e desértico. Considerando este propósito de uso, na avaliação da qualidade das águas da área de pesquisa, foi utilizado o Diagrama Logarítmico de SCHOELLER (FIGURA.35). Neste diagrama observa-se uma classificação segundo 
os limites toleráveis de potabilidade, estabelecidos pelas normas nacionais e internacionais de cada um dos elementos envolvidos. O gráfico mostra que as águas analisadas são de boa qualidade, com baixo conteúdo de cloretos, sulfetos e bicarbonatos.

Como complemento, na TABELA 36 apresenta-se a ocorrência do Arsênio na composição química das águas do aqüífero livre da zona de Charaña, Bolívia, onde suas concentrações variam entre $0,034 \mathrm{mg} / \mathrm{L}$ a $0,231 \mathrm{mg} / \mathrm{L}$. Segundo as normas de potabilidade da OMS, considera como limite permissivel de presença do Arsênio em águas de consumo valores entre $0.02 \mathrm{mg} / \mathrm{L}$ a $0,05 \mathrm{mg} / \mathrm{L}$. Porém, a USEPA, (2002) propõe um novo standard cujas concentrações deve ser inferiores a $0,01 \mathrm{mg} / \mathrm{L}(10 \mu \mathrm{g} / \mathrm{L})$. As novas exigencias estão relacionadas a efeitos tóxicos muito graves gerados pelo consumo de água com Arsênio observadas em diversos paises, fundamentalmente em Bangladesh (DHAR et al., 1997).

Pesquisas sobre a ocorrência do Arsênio em águas subterrâneas, mostram que estas encontram-se associadas a áreas geotermais (STAUFFER \& THOMPSON, 1984), regiões vulcânicas (WELCH, et al. 1988), horizontes de argilas interestratificados com materiais detriticos portadores de minerais de Arsênio (HEINRICHS \& UDLUFT, 1999), e aqüiferos que contem óxidos de ferro e manganês que associam-se com o Arsênio (KORTE \& FERNANDO, 1991). Com base nas considerações apresentadas, a sub-bacia Uchusuma encontra-se em uma zona de predominio de rochas vulcânica, intensa manifestação geoternal e ocorrência de águas mineralizadas, que misturam-se com águas de boa qualidade procedentes do degelo de nevados e infiltração de precipitações.

TABELA 36 - OCORRÊNCIA DE ELEMENTOS TÓXICOS, ZONA DE CHARAÑA - BOLIVIA

\begin{tabular}{ccc} 
Poço & Concentraçäo mg/t \\
\hline 1 & Data & As \\
2 & $10 / 2001$ & 0,034 \\
6 & $10 / 2001$ & 0,094 \\
7 & $10 / 2001$ & 0,100 \\
9 & $10 / 2001$ & 0,154 \\
11 & $10 / 2001$ & 0,231 \\
\hline
\end{tabular}

Amostra analisado no laboratório CEPAS USP -2000

Além da ocorrência do Arsênio, em áreas adjacentes à sub-bacía Uchusuma ocorrem fontes mineralizadas com alto conteúdo de Boro. Isto foi determinado nos 
"Estudos de Hidrotermalismo de las Pampas de Callapuma y alrededores" realizado pelo Proyecto Especial Tacna, indicando que as fontes mineralizadas encontram-se no local denominado "Boratera de Calachaca" com 8,13 mg/L até $61,21 \mathrm{mg} / \mathrm{L}$ de boro, e no local "Chungara" com conteúdos de $17 \mathrm{mg} / \mathrm{L}$ a $40 \mathrm{mg} / \mathrm{L}$.

Problemas de contaminação natural de águas superficiais e subterrâneas nas áreas alto-andinas é freqüente pelo vulcanismo ativo da Cordilheira Ocidental dos Andes, às quais estão vinculadas as águas mineralizadas e ocorrência de jazidas de Boro, Enxofre e outros minerais.

TABELA 37 - NORMAS DE POTABILIDADE

\begin{tabular}{|c|c|c|c|c|c|}
\hline \multirow[t]{2}{*}{$\begin{array}{l}\text { Parametro } \\
\text { quimica }\end{array}$} & \multicolumn{2}{|c|}{$\begin{array}{l}\text { Organizaçäo Mundial de Saude OMS } \\
\qquad \mathrm{mg} / \mathrm{L}\end{array}$} & \multirow[t]{2}{*}{$\begin{array}{l}\text { U.S.P.H.S } \\
\text { Mg/L }\end{array}$} & \multirow[t]{2}{*}{$\begin{array}{c}\text { Normas } \\
\text { Peruanas }^{3} \mathrm{mg} / \mathrm{L}\end{array}$} & \multirow[t]{2}{*}{$\begin{array}{c}\text { Normas Bolivianas } \\
\mathrm{mg} / \mathrm{L}\end{array}$} \\
\hline & Permissivel & Execessivo & & & \\
\hline$p H$ & $7,0-8,5$ & $6,5 \cdots 9,2$ & & 8,5 & 8,5 \\
\hline Sólidos tatais & 500 & 1500 & 500 & 1000 & \\
\hline Dureza $\left(\mathrm{CaCO}_{3}\right)$ & - & + & - & 500 & 500 \\
\hline Cálcio (Ca) & 75 & 200 & - & - & - \\
\hline Magnesio $(\mathrm{Mg})$ & 125 & 125 & 125 & 160 & \\
\hline Sulfeto $\left(\mathrm{SO}_{4}\right)$ & 200 & 400 & 250 & 400 & 400 \\
\hline Cloreto(Cl) & 250 & 600 & 250 & 250 & 250 \\
\hline Fluor $(F)$ & 1,5 & 1,5 & $1,6-2,4$ & $\cdots$ &. \\
\hline Nitrato $\left(\mathrm{NH}_{3}\right)$ & 0,5 & 0,5 & - & 10 & 10 \\
\hline Ferro (Fe) & 0,3 & 1,0 & 0,3 & 0,3 & - \\
\hline Manganês (Mn) & 0,1 & 0,5 & 0,05 & 0.1 & 0,3 \\
\hline Cobre $(\mathrm{Cu})$ & 1,0 & 1,5 & 1,0 & 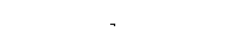 & - \\
\hline Niquel (Ni) & 0,01 & - & 0,034 & - & - \\
\hline $\operatorname{Zinco}(Z n)$ & 5,0 & 15,0 & 5,0 & - & - \\
\hline Molibdeno (Mo) & - & - & 0,068 & - & - \\
\hline Chumbo $(\mathrm{Pb})$ & 0,1 & 0.1 & $0,1-0,05$ & 0,1 & 0,05 \\
\hline Arsénico (As) & 0,02 & 0,05 & $0,01-0,05$ & 0,05 & 0,05 \\
\hline Bário (Ba) & 0.3 & 0,5 & 1,0 & - & - \\
\hline Selênio (Se) & 0,05 & 0,05 & 0,01 & - & - \\
\hline Cromo $\left(\mathrm{Cr}^{+6}\right.$ & 0,01 & 0,05 & 0,05 & - & - \\
\hline Cádmio (Cd) & 0,05 & 0,05 & 0,01 & 0,005 & 0,005 \\
\hline Cianeto (CN) & 0,01 & 5,0 & $0,01-0,2$ & - & - \\
\hline Mercúrio (Hig) & - & - & - & 0,001 & 0,001 \\
\hline Sódio (Na) & & & & 200 & 200 \\
\hline Boro (B) & - & $\therefore$ & - & 2,0 & - \\
\hline
\end{tabular}



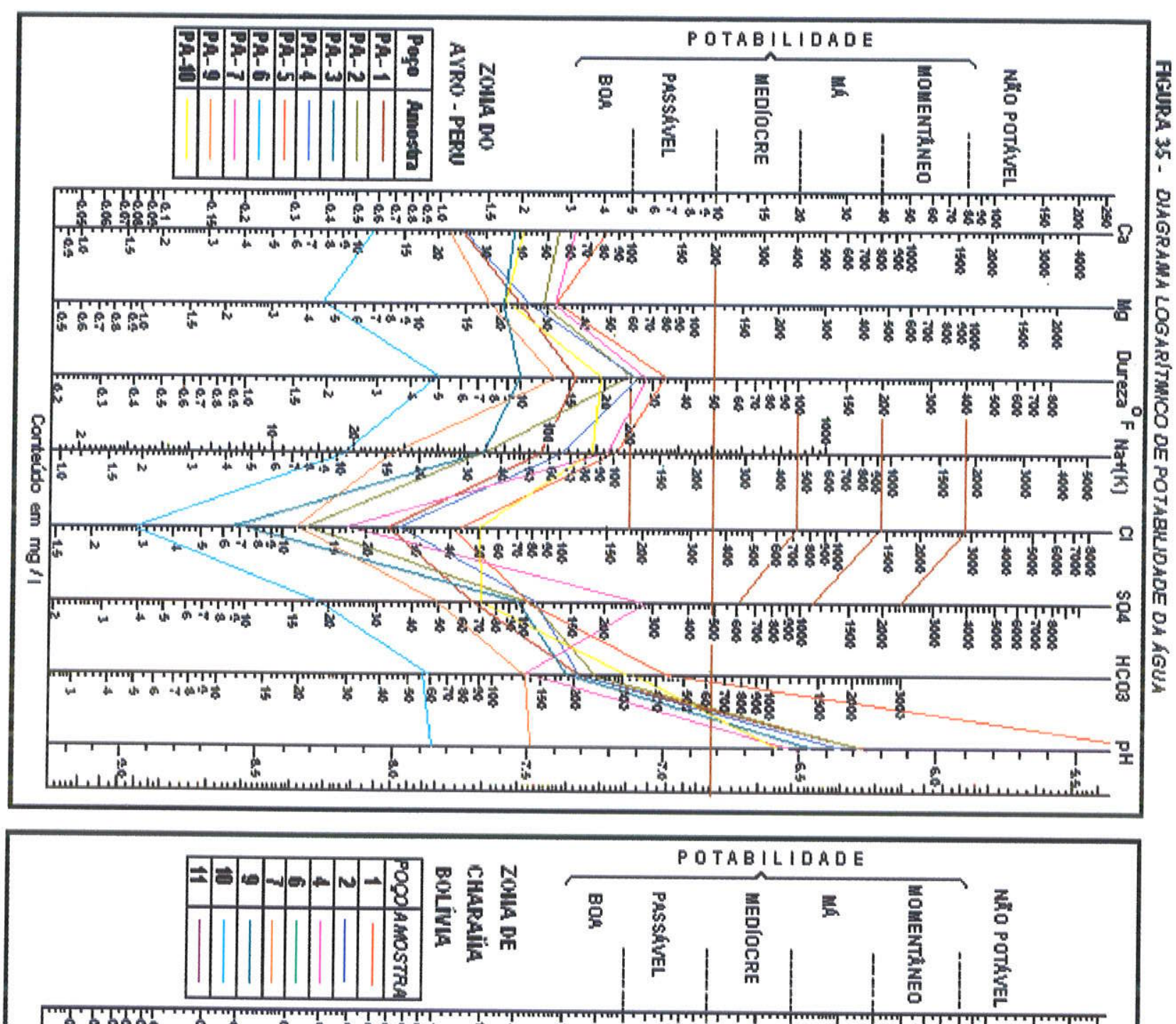

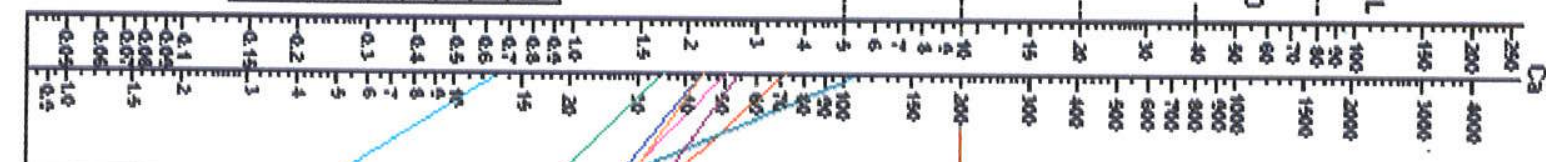

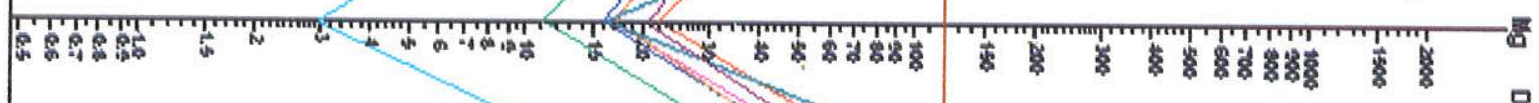

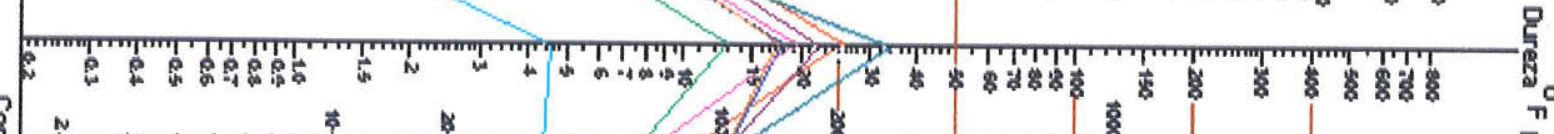
\&

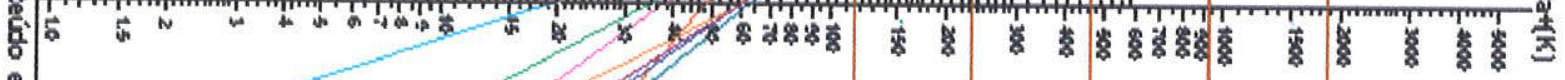

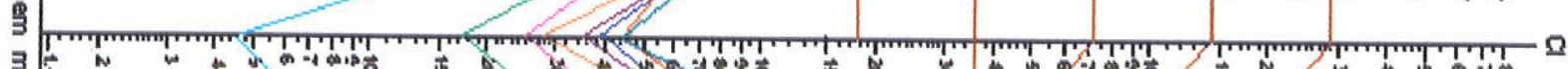

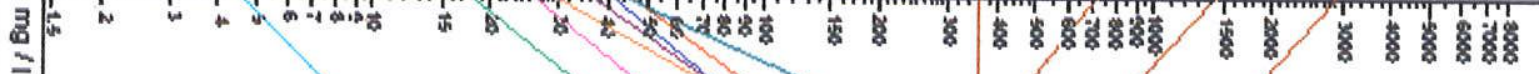

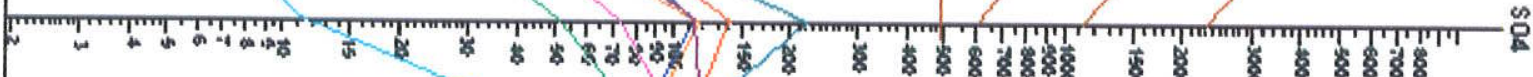

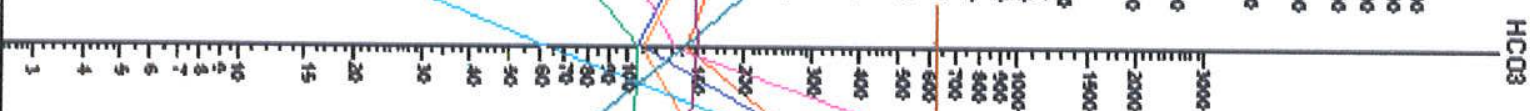

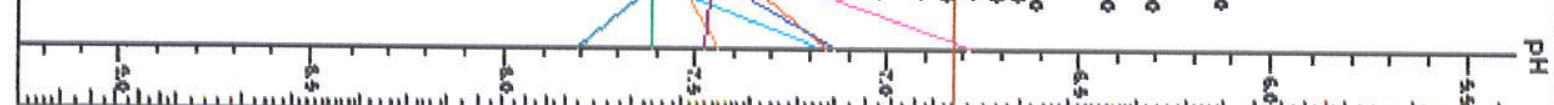

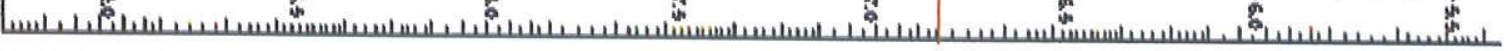




\section{CAPITULO IX}

\section{RESERVAS HÍDRICAS}

\subsection{0.- Avaliação de reservas}

As reservas de águas subterrâneas representam os volumes naturalmente estocados, de forma permanente ou periódica, nos diferentes reservatórios formados por sistemas aqüiferos locais ou regionais. Os volumes estocados, sendo relativamente muito grandes e suas velocidades de fluxo muito baixas, resulta que as reservas de águas subterrâneas são pouco afetadas pela ausência de precipitações na época de estiagem. Em conseqüência, proporcionam recursos de grande valor social e econômico para atendimento das demandas do desenvolvimento social e econômico das civilizações. Por esta prerrogativa merece uma atenção especial avaliar as disponibilidades existentes e, a partir destas, planificar um aproveitamento sustentável.

Em muitas regiões do mundo há problemas de escassez de água por se encontrarem em áreas geográficas de clima árido ou desértico. A região litorânea sul do Peru e norte do Chile, como foi apresentado no capitulo 1, caracteriza-se por escassez de recursos hídricos. Nestas áreas encontram-se assentadas várias cidades em desenvolvimento. A grande demanda de água para atender as necessidades destes municípios, como de Tacna no Peru, obriga-os a abastecerem-se de bacias exteriores como o rio Uchusuma, que pertence ao sistema hídrico fechado "Lago Titicaca, Desaguadero, Poopó Salar de Coipasa", onde as características hidrológicas oferecem melhor renovabilidade sazonal das reservas de águas subterrâneas, embora nestas regiões registra-se escassa precipitação, e em conseqüência, os recursos explotáveis variam no espaço e no tempo.

Considerando que o município de Tacna do Peru depende dos recursos hídricos da sub-bacia do rio Uchusuma, é importante examinar o volume de reservas renováveis desta sub-bacia e como pode ser gerenciado de modo racional evitando uma explotação devastadora em prejuizo dos ecossistemas do Altiplano.

Ė necessário considerar, como sugere REBOUÇAS et.al., (1994), que no 
planejamento e gestão integrada dos recursos hidricos de uma região é fundamental caracterizar considerações de maior ou menor renovabilidade das reservas dos aqüiferos subterrâneos. Com esta finalidade foi necessário estimar o potencial hídrico e disponibilidade de água sazonal no domínio da área pesquisada, a partir do conhecimento das caracteristicas sedimentares e geométricas do reservatório e do aqüifero das formações Capillune e Maure.

As reservas tem sido tradicionalmente classificadas em renováveis e não renováveis. Contudo, esta classificação é, de certa forma artificial, na medida em que não existem águas subterrâneas desconectadas do ciclo hidrológico. Na maioria dos casos os tempos de residência das águas nos aqüiferos é da ordem de dezenas de anos, em alguns casos atinge-se a escala de centenas e até de milhares de anos (REBOUÇAS et.al. , 1994)

As reservas totais, ou naturais, são representadas pelo conjunto das reservas permanentes e reservas reguladoras, constituindo, assim, a totalidade de água existente num aqüiffero ou sistema aqüífero (DUARTE 1997).

\subsection{0.- Reservas reguladoras ou transitórias}

Correspondem aos volumes das recargas anuais ou sazonais que recebe o sistema. Normalmente a descarga destas águas contribuim para a rede hidrográfica durante o ano, como fontes de alimentação de mananciais e vazão de base dos rios.

Para a estimativa de reservas reguladoras existem três métodos usuais: 1).- a partir da equação de escoamento Natural (DUARTE, 1997), 2).- taxa de infiltração como foi utilizado por AMORE (1994) e outros pesquisadores, 3).- através da medição do nivel mais elevado e do nivel mais baixo da superficie potenciométrica (CUSTODIO, 1996). O critério aplicado para a área de pesquisa foi a partir de flutuações potenciométricas, por considerar um dado mais representativo, que torna evidente o volume de água infiltrado no meio local e regional, representa a somatória das recargas que o aqüífero recebe na área de influência da bacia. Em termos de benefício, representa a disponibilidade potencial existente de águas em trânsito que se estimou pela seguinte formula: 


$$
R r=A \times h^{\prime} \times S \quad(30)
$$

Onde:

$A=$ Área de influência da bacia $\left(624 \times 10^{6} \mathrm{~m}^{2}\right)$

$h^{\prime}=$ Flutuação potenciométrica local $(1,94 \mathrm{~m}$ anual $)$

$\eta_{e}=$ Porosidade efetiva do aqüifero Capillune $\left(1,7 \times 10^{-2}\right)$

$R r=$ Reservas reguladoras $\left(m^{3}\right)$

$R r=624 \times 10^{6} \mathrm{~m}^{2} \times 1,94 \mathrm{~m} \times 1,7 \times 10^{-2}$

$\underline{R r}=20,6 \times 10^{6} \mathrm{~m}^{3}$ /ano

\subsection{0.- Reservas permanentes.}

Em regiões de clima árido ou semi áridos, as reservas permanentes constituem a base do desenvolvimento agricola. Geralmente estas reservas participam no ciclo hidrológico numa escala de tempo plurianual, centenária ou milenária. Está constituída pelo volume de água estocado abaixo das flutuações anuais da zona saturada. O método clássico de estimativa leva em consideração a extensão de ocorrência do aqüifero, espessura média saturada e coeficiente de armazenamento (REBOUÇAS et al., 1994), (CAVALCANTE, 1990).

\begin{tabular}{lcc} 
& $\begin{array}{c}R p=A \times h \times \eta_{\mathrm{e}} \\
(31)\end{array}$ & $\begin{array}{c}R p=A \times h \times S \\
(32)\end{array}$ \\
\hline Onde : & Aqüifero livre Capillune e fluvio glacial & $\begin{array}{c}\text { Aquifero semi-confinado } \\
\text { Maure }\end{array}$ \\
\hline$A=$ Area da zona pesquisada & $624 \times 10^{6} \mathrm{~m}^{2}$ & $624 \times 10^{6} \mathrm{~m}^{2}$ \\
$h=$ Espessura média do aqüifero & $36 \mathrm{~m}$ & $98 \mathrm{~m}$ \\
$S=$ Coeficiente de armazenamento & & $9 \times 10^{-3}$ \\
$\eta_{e}=$ Porosidade efetiva & $1,7 \times 10^{-2}$ & \\
$R p=$ Reservas permanentes & $381,9 \times 10^{6} \mathrm{~m}^{3}$ & $550,4 \times 10^{6} \mathrm{~m}^{3}$ \\
\hline$T R P=$ Total de Reservas permanentes & & $932,3 \times 10^{6} \mathrm{~m}^{3}$
\end{tabular}

\subsection{0.- Vazão de oferta.}

Constitui a quantidade máxima de água que poderia ser explotada de um aqüifero, sem riscos de prejuízos ao manancial. Esta reserva está integrada pelas reservas reguladoras e uma parcela das reservas permanentes (DUARTE, 1997). Por se tratar de um volume/tempo, os recursos explotaveis expressam, na 
realidade, uma vazão segura, definida por Meinser (1920) como "aquela vazão de extração do aqüifero que pode manter-se permanentemente, proporcionando água apta para o uso humano"

Em termos de beneficio para a estimativa da reserva de explotação considerou se a somatória do volume de reservas reguladoras, mais $4 \%$ do volume de reservas. permanentes, que não produziriam efeitos negativos no equilibro do ecossistema. O volume de explotação apenas provocaria rebaixamentos menores a $10 \mathrm{~m}$, situação que pode ser controlada com uma adequada gestão de águas subterrâneas.

\section{$R e=R r+R p$}

Onde:

$$
\begin{aligned}
& R e=\text { Reservas de explotação } \mathrm{m}^{3} \text { /ano } \\
& R r=\text { Reservas reguladoras } 20,6 \times 10^{6} \mathrm{~m}^{3} \\
& R p=4 \% \text { de Reservas permanentes }=37,29 \times 10^{6} \mathrm{~m}^{3} \\
& R e=20,6 \times 10^{6} \mathrm{~m}^{3}+37,29 \times 10^{6} \mathrm{~m}^{3} \\
& \underline{R e}=57,9 \times 10^{6} \mathrm{~m}^{3} \text { /ano. }
\end{aligned}
$$$$
A \text { vazão de oferta }=1,8 \mathrm{~m}^{3} / \mathrm{s} \text {. }
$$

Esta vazão de oferta se justifica ao analisarmos o registro histórico de volume de explotação de poços pelo Proyecto Especial Tacna (TABELA 37) da zona do Ayro, do período de dezembro de 1991 a abril de 1992. A esta informação deve ser somada a vazão de águas superficiais da sub-bacia em temporada de estiagem, que são alimentadas por águas subterrâneas e mananciais que afloram em diferentes boçorocas naturais.

\subsubsection{Potencialidade hídrica.}

Segundo o conceito de potencialidade, definido por muitos pesquisadores, é constituido pelo volume total acumulado na zona de saturação e sujeito à extração. Isto eqüivale na prática, às reservas totais do aqüifero: 
Onde:

$$
\begin{aligned}
& R t=\text { Reservas totais } \mathrm{m}^{3} \text { lano } \\
& R r=\text { Reservas reguladoras } 20,6 \times 10^{6} \mathrm{~m}^{3} \\
& R p=\text { Reservas permanentes }=932,3 \times 10^{6} \mathrm{~m}^{3} \\
& R e=20,6 \times 10^{6} \mathrm{~m}^{3}+932,3 \times 10^{6} \mathrm{~m}^{3} \\
& R t=952,9 \times 10^{6} \mathrm{~m}^{3} \text { /ano. }
\end{aligned}
$$

Do volume calculado, pode ser explotado $57,9 \times 10^{6} \mathrm{~m}^{3} / \mathrm{ano}$ da sub-bacia do rio Uchusuma

TABELA 38: REGISTRO DE VOLUME DE EXPLOTAÇÃO DE RECURSOS HIDRICOS DA ZONA DO AYRO PERU

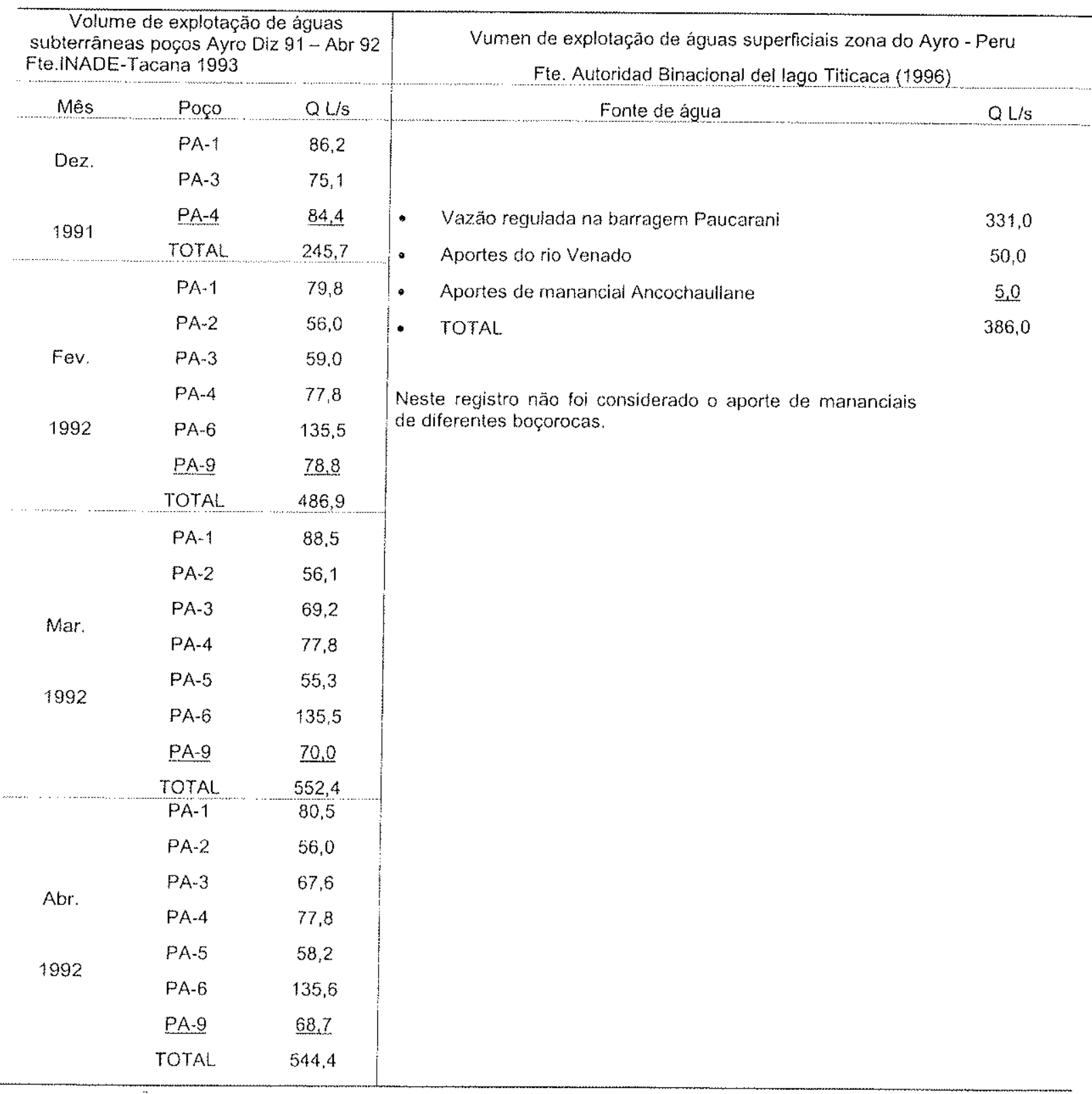




\section{CAPITULO $X$}

\section{PROBLEMAS AMBIENTAIS.}

\subsection{0.- Considerações gerais.}

Nas últimas décadas moradores de áreas Alto Andinas do Peru e da Bolivia, deram a conhecer, em vários eventos, o problema de redução e perda de extensas área úmidas em diferentes bacias do Altiplano ocidental, apontando como o principal gerador do impacto negativo a explotação descontrolada de águas superficiais e subterrâneas por Municípios do litoral do Chile e do Peru. As áreas mais prejudicadas com esta problemática ambiental encontram-se situados no Altiplano ocidental que compreende o espaço territorial das comunidades camponesas Aymaras da Bolivia e do Peru.

Do ponto de vista ecológico, nos vales do Altiplano existe um ecossistema associado a áreas úmidas produtoras de flora nativa (zonas hidromorficas). Essas áreas de desenvolvimento de comunidades vegetais geralmente estão localizadas ao longo das boçorocas naturais, fundo dos vales e terras baixas alimentadas por fluxos subsuperficiais de águas infiltradas. Para a economia do povo Aymara, as áreas hidromórficas constituem zonas de pastagem do gado nativo e são cuidadosamente aproveitadas.

Os problemas ambientais ocasionados pela explotação das águas superficiais e subterrâneas por municipios do litoral, data desde 1860 em diante (Jornal Prensa 1999). Nos anos recentes observa-se maior demanda de água de setores produtivos do litoral e existem novos projetos de captação de águas do Altiplano, situação esta que vem levantado demandas reivindicatorias pela população rural Aymara e maiores conflitos de ordem social e político entre regiões. No que concerne à sub-bacia do rio Uchusuma, como foi mencionado em capítulos precedentes, o volume de águas explotando pelo município de Tacna atinge a $3016,8 \mathrm{~m}^{3} / \mathrm{h}(\mathrm{ALT}, 1996)$ 
10.2.0.- Impacto ambiental gerado pela explotação de águas subterrâneas

\subsection{1.- Avaliação de áreas úmidas e mananciais}

Os efeitos ambientais causados por problemas de explotação dos recursos hídricos foram avaliados, com ênfase naquelas áreas adjacentes a poços de captação de águas subterrâneas, zonas baixas no local de captação de águas do rio Uchusuma e boçorocas naturais responsáveis pela manutenção do nível de base do rio Uchusuma.

\section{a).- Zona hidromórfica Vilapucara (FIGURA 36)}

$\mathrm{Na}$ boçoroca Vilapucara, das suas nascentes até o ponto de descarga no rio Uchusuma, existem numerosos mananciais, dos quais 8 destacam-se por apresentar uma vazão entre 54 a $97,2 \mathrm{~m}^{3} / \mathrm{h}$. Além destas, existem outras fontes de menor vazão ao longo do vale. Segundo informações levantadas no campo, os habitantes do lugar indicam que, antes dos anos 1980, existiam inúmeros mananciais de regime perene e fauna ligada a estas umidades. Estas áreas foram reduzindo-se de maneira progressiva pela exploração de águas subterrâneas através de quatro poços profundos (PA: 6, 9, 12, 13) existentes nesta área.

A falta de dados históricos de vazão de mananciais da boçoroca Vilapucara, inviabiliza a avaliação da situação atual com referência a épocas passadas.

\section{b).zonas hidromórficas localizadas na jusante da captação "El Ayro"}

$\mathrm{Na}$ zona abaixo do ponto de captação das águas do rio Uchusuma (Bocatoma El Ayro)circunscrita pelos poços PA-4, PA-2, PA-1, temos dentro do vale áreas degradadas sem vegetação, do mesmo modo que no território boliviano (FIGURA 36 p:151), especificamente na zona de Charaña, o vale do rio Uchusuma encontra-se completamente seco em uma distância aproximada de $9 \mathrm{Km}$, desde as planícies de "Charaña pampa" até a confluência com o rio Putani. Segundo o jornal PRESENCIA, (06 de dezembro 2000), o impacto teria ocasionado a perda de 600 hectares de terras úmidas de comunidades camponesas no lado boliviano. O problema ambiental vincula-se ao desvio da totalidade das águas do rio Uchusuma. Os efeitos negativos ressaltam na imagem de satélite (FIGURA 14, p: 53) 


\section{c).; Zonas hidromórficas no entorno do local "Laguna Blanca"}

Existem algumas evidências de que em épocas passadas, a área de "Laguna Blanca", foi zona produtora de culturas nativas, alimentadas por escoamento superficial das águas da boçorocas $Q^{\circ}$ Queñuta. Na atualidade, o problema de desvio das nascentes desta boçoroca tem gerado a secagem das áreas úmidas.

Esta problemática tem-se tornado mais grave pelo efeito de uma contaminação natural por águas subterrâneas mineralizadas provenientes da zona de Huayllata, onde existem fontes hidrotermais. O parâmetro da condutividade elétrica medida nos poços PA-7 e PA-5, mostra valores de $850 \mu \mathrm{S} / \mathrm{cm}$ a $1013 \mu \mathrm{S} / \mathrm{cm}$. Estes valores incidem de maneira progressiva na degradação de solos.

\section{d).- Impacto da explotação de água subterrâneas}

Na zona do Ayro Perú (Área 1), observa-se que o regime de bombeamento dos diferentes poços de produção tem ocasionado efeito negativo nas áreas hidromórficas dentro dos limites do raio de influência do cone de rebaixamento. Zonas degradadas, com problemas de secagem, foram identificadas na área circundante aos poços PA - 03, e na boçoroca Vilapucara, nas proximidades dos poços PA - 06, PA - 12 e PA - 13

\subsection{0.- Problemas sócio - econômicos vinculados à derivação de água do Altiplano ao Pacífico}

Os diferentes problemas sociais e econômicos vinculados à derivação das águas do altiplano para o litoral podem ser sintetizados nos seguintes aspectos:

- do ponto de vista cultural, o Altiplano peruano, boliviano, compreende um território onde desenvolveu-se uma civilização ancestral denominada o povo Aymara, dedicada fundamentalmente, à atividade agropecuária. Desde o início a implementação de projetos de derivação de águas do Altiplano para o litoral Pacífico, tem-se convertido em uma ameaça para a sobrevivência desta população rural. Nos últimos 50 anos, segundo o parlamento Aymara muitas das comunidades camponesas, por falta de condições de vida, têm migrado para as cidades, incrementando o nivel de pobreza nos centros urbanos e falta de oportunidade de trabalho. 
- equilibro da existência cultural do povo Aymara em um espaço geográfico como o Altiplano, está ligado ao equilibro do ecossistema existente a altitudes de $4000 \mathrm{~m}$. Esta correspondência tem-se desarticulado através dos anos por interesses de ordem politica e econômica, ocasionando um desequilibro na conservação da flora e fauna existentes nos vales do Altiplano, incremento de áreas ameaçadas com secagem de solos, e alteração da qualidade das águas por efeito de uma mistura com águas mineralizadas ou, em outros casos ocasionados pela atividade da mineração,

- as constantes lutas de comunidades camponesas pela reivindicação, não tem tempo para acabar. O problema envolve governantes dos países do Peru, Bolivia e Chile, tornando-se em um conflito de interesses econômicos, com prejuizo para as classes pobres.

\subsection{0.- .- Problemas de gerenciamento da bacias}

O problema de gerenciamento das bacias parte da dificuldade legislativa, observando-se uma falta de vontade politica para definir a lei das águas bastante postergada, há mais de 10 anos encontra-se em processo de revisão e análise. Múltiplos fatores econômicos, sociais, politicos e culturais dificultam a tarefa de formular uma proposta que concilie eficiência e equidade no uso das águas. Observa-se que a nivel nacional a agricultura consome aproximadamente o $85 \%$ da água utilizada no Pais (REBOS1O, 2003). A esta incrementa-se a demanda crescente de setores urbanos para satisfazer as necessidades de desenvolvimento, principalmente das cidades litorâneas, onde a exploração das águas subterrâneas está alcançando niveis que superam a capacidade de renovabilidade sazonal.

Por outro lado não existe um real conhecimento da demanda de água dos setores econômicos e sociais, que permita estabelecer planos efetivos de desenvolvimento em função aos recursos hídricos disponiveis. Dentro deste assunto, é necessário tomar medidas de prevenção para os cenários futuros, pois a demanda hídrica irá aumentar e precisa ser administrada por um modelo de gestão da demanda, ao invés da cultura tradicional de gerenciar a oferta. 
10.5.0. - Conflitos regionais por recursos hidricos.

O aproveitamento das grandes áreas desérticas do litoral do Pacífico para a agricultura, são projetos que vêm norteando o desenvolvimento econômico das regiôes de fronteira dos paises do Peru e Chile. Neste objetivo a água constitui um recurso estratégico de desenvolvimento, onde cada pais pretende controlar e aproveitar ao máximo os recursos disponiveis no domínio do espaço territorial. Esta tendência pode gerar conflitos entre nações pela falta de entendimento no uso dos recursos hidricos. Corresponde, a nivel dos governos, estabelecer mecanismos de cooperação entre países para gerenciar os recursos hídricos e promover um desenvolvimento equilibrado das áreas de fronteira. 


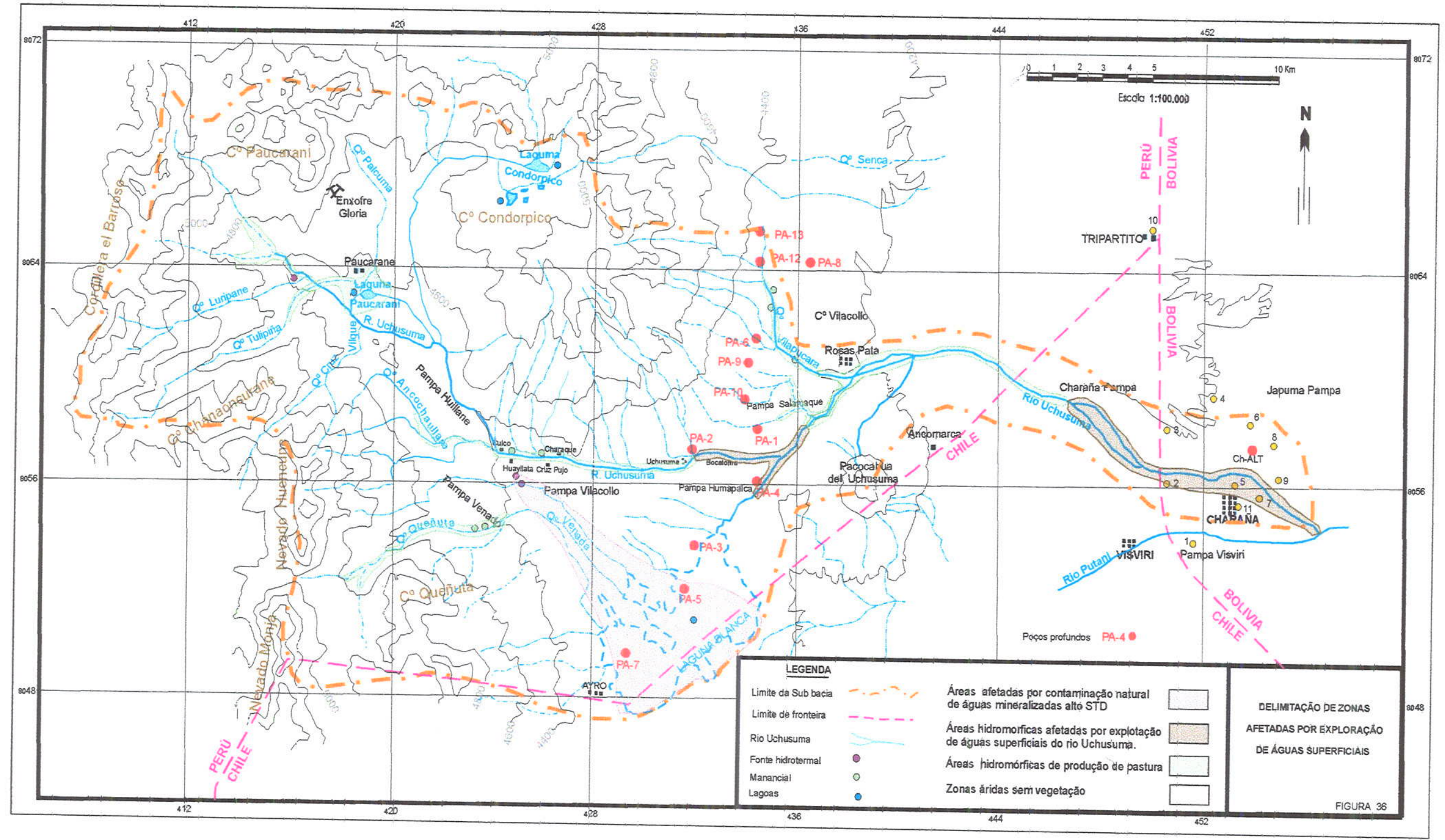




\section{CAPITULO XI}

\section{CONCLUSÕES ERECOMENDAÇÕES.}

Neste item, sintetiza-se o conhecimento das caracteristicas físicas e dinâmicas que compõem o sistema avaliado. A FIGURA 37 P. 159, representa o modelo conceitual que resume aspectos da estrutura da sub-bacia e esquema da dinâmica de fluxos em relação aos componentes litoestratigráficos, propriedades hidrodinâmicas, e hidrometeorológicas. Essas variáveis definem de algum modo, as características hidrogeológicas do reservatório local

1.- Em termos de balanço hídrico, a análise de freqüência de precipitações, que incide na recarga de aqǘferos, mostra um regime pluviométrico irregular, predomínio de condições de aridez e longos períodos de intensa sêca. Dados pluviométricos analisados de um período de 39 anos, indicam uma escassa precipitação na zona do Altiplano ocidental atingindo uma média de 331 $\mathrm{mm} / a n o$. Deste volume o aqüifero recebe apenas uma recarga máxima de 64 $\mathrm{mm}$ nos meses de janeiro a março, mostrando um desequilibro substancial em relação a taxa de ETP que atinge a $1108 \mathrm{~mm} / \mathrm{ano}$, valor que foi estimado a partir de dados de evaporimetro tanque classe " $A$ ".

2.- As características geométricas do reservatório e do aqüifero está definida pelo sistema de falhas $N-S$, e outras falhas transversais, a qual facilitou o desenvolvimento local de pequenas bacias sedimentares de profundidades aproximadas de $300 \mathrm{~m}$, como na zona do Ayro e Zona de Charaña, e com limites de contorno constituído pelos altos relevos da Formação do Vulcânico Barroso (Cordilheira El Barroso). Em profundidade segundo a estratigrafia regional provavelmente esteja limitado pela Formação do Vulcânico Huilacollo, do Terciario inferior no Peru e derrames de lava da Formação Abaroa na Bolívia

3.- O comportamento da dinâmica dos fluxos no reservatório, está controlado por três unidades estratigráficas com características físicas e sedimentares particulares: na base do reservatório encontra-se a Formação Maure do Pliocêno inferior (aqüifero semi-confinado), no topo apresenta-se a Formação 
impermeável Sencca ou Pérez do Pliocêno médio e sobre esta unidade descansa a Formação Capillune do Plioceno superior (aqüifero livre).

- A natureza sedimentar do aqüifero semi-confinado Maure está composto por uma seqüência vulcano-sedimentar interestratificada de: conglomerados, arenitos quartzosos de granulometria variada, siltitos de cor verde escuras, camadas de material vulcânico retrabalhado, piroclastos, horizontes de cinza, e argelitos. A maior espessura desta formação foi constatada em $110 \mathrm{~m}$ na perfuração do poço de Charaña PCH_ALT. Em outras áreas do Altiplano atinge uma espessura de $1300 \mathrm{~m}$ de espessura.

- Estruturalmente o aqüifero Maure encontra-se parcialmente confinado (semi-confinado) por uma espessura de 25 a $80 \mathrm{~m}$ de ignimbritos da Formação Sencca de composição dacítica a riolítica. Embora esta unidade seja de natureza compacta e impermeável (110 ohm.m a 263 ohm.m nos SEVs), encontra-se afetado por uma deformação ruptil. Esta característica estrutural gerou uma permeabilidade secundaria, determinante no controle de fluxos como nas relações entre aqüiferos.

- No topo da Formação Sencca entra em contato o aqüifero livre da Formação Capillune, composto por sedimentos lacustrinos - fluviais, intercalado com materiais vulcânicos retrabalhados: areias, cascalhos de diferente granulometria, gradando a horizontes de siltes argilosos, horizontes de lapillitos em matriz tufitica, areias tufáceas de cor branca a verde amarela. Esta formação foi identificado no perfil dos poços perfurados, PA-1, PA-2, PA-3, PA-4 e PA-10, com espessura que varia entre 11 e $24 \mathrm{~m}$ e uma máxima de $210 \mathrm{~m}$ nos PA-5 e PA-7.

4.- As propriedades hidrodinâmicas dos aqüíferos Maure e Capillune, varia tridimensionalmente pela natureza heterogênea do material sedimentar. Esta condição está relacionado à interestratificação de pequenas camadas de granulometria variada alguns com frentes digitadas. A heterogeneidade sedimentar determina a variabilidade dos indices hidrodinâmicos no espaço físico. Porém, os parâmetros determinados no teste de bombeamento, apenas 
representam uma condição geral do meio, e os diferentes valores encontrados, como outros determinados pela empresa construtora durante a etapa de perfuração dos poços, mostram essa realidade física da heterogeneidade. Em conseqüência, os parâmetros de K,T, S e ne, estimados para os aqüíferos Maure e Capillune e em função da produção dos poços, pode se interpretar que o reservatório da sub-bacia Uchusuma constitui um meio de alta capacidade produtiva. Na tabela a seguir são apresentados os parâmetros que podem ser considerados representativos dos aqüíferos Maure e Capillune.

\begin{tabular}{|c|c|c|c|c|c|c|}
\hline $\begin{array}{l}\text { Zona de } \\
\text { avaliação }\end{array}$ & $m^{2} / d i a$ & $\begin{array}{c}k \\
m / d i a\end{array}$ & $\begin{array}{l}\text { Coeficiente de } \\
\text { armazenamento } s\end{array}$ & $\begin{array}{c}\text { Porosidade } \\
\text { efetiva } \\
\end{array}$ & $\begin{array}{c}\text { Método de } \\
\text { interpretação }\end{array}$ & $\begin{array}{c}\text { Formação } \\
\text { aqüifera }\end{array}$ \\
\hline Área 1 & 1959,5 & 32,00 & $9 \times 10^{3}$ & & Theis & Maure \\
\hline Area 2 & 434,8 & 11,14 & & & $J a c o b$ & Maure \\
\hline Area 1 & 189,9 & $2,11^{\star}$ & & $1.7 \times 10^{2}$ & Jacob & Capillune \\
\hline
\end{tabular}

PA: Poço Ayro, PCA: Poço de controle Ayro, PCh-ALT: Poço Charaña Autoridad Lago Titicaca.

Os dados de capacidades especificas de produção dos diferentes poços

\begin{tabular}{|c|c|c|c|c|c|}
\hline Poço & $\begin{array}{c}\mathrm{Q} / \Delta \\
\left(\mathrm{m}^{3} / \mathrm{h} \cdot \mathrm{m}\right)\end{array}$ & Aqüiffero & Poço & $\begin{array}{c}Q / \Lambda \\
\left(m^{3} / h \cdot m\right)\end{array}$ & Aqüifero \\
\hline PA-1 & 15,78 & Maure+Capillune & PA-5 & 4,83 & Capillune \\
\hline PA-2 & 6,59 & Maure+Capillune & PA.6 & 13,80 & Mure \\
\hline PA-3 & 29,83 & Maure+Capillune & $\mathrm{PA}+7$ & 4,38 & Capilfune \\
\hline PA-4 & 8,30 & Maure+ Capillune & PA.9 & 10.00 & Maure+Capillune \\
\hline
\end{tabular}

5.- O sistema avaliado é favorecido por dois mecanismos de recarga:

- um de caracter sazonal, ligado à época de precipitação, onde o sistema recebe um aporte de $64 \mathrm{~mm} / a n$. Nesta época o efeito da recarga é favorecida pelo controle topográfico de uma ampla área que apresenta um relevo suave com uma gradiente entre $3,4 \%$ a $1,6 \%$ em zona de planície. Esta condição, aliada as características sedimentares da sub-bacia, facilita uma infiltração efetiva; 
* periodo de recarga continua de menor volume é efetivada durante a época de estiagem por águas provenientes do degelo de neves, infiltração das águas superficiais existentes na área de pesquisa como lagoa Paucarani e Tiapujo, e infiltrações do rio Uchusuma que contribuem fundamentalmente na recarga do aqüífero Capuillune. No entanto, o aqüifero Maure recebe aportes regionais provenientes da vertente da cordilheira ocidental dos Andes.

6.- Pelas caracteristicas estruturais do reservatório, existe uma relação entre aqüiferos, onde a Formação dos Ignimbritos Sencca facilita o fluxo vertical através das fraturas e falhas desenvolvida nesta formação. Deste modo o aqüifero Capillune recebe recarga do aqüifero Maure pela diferença de carga hidráulica encontrada entre elas

7.- Com base nas considerações anteriores o aqüifero Capillune recebe importantes contribuições em matéria de recarga. Esta característica influi na localização do nível freático, encontrando-se desde $14,60 \mathrm{~m}$ nas zonas altas, a $0,14 \mathrm{~m}$ em zonas baixas (Planície de Laguna Blanca). Esta superfície flutua segundo as estações, seja de precipitação ou de estiagem, de 1,94 m na zona do Ayro (área 1), e 1,40 m na zona de Charaña (área 2). De outra parte, segundo a morfologia de curvas equipotenciais do aqüífero livre, os fluxos deslocam-se sob um gradiente hidráulico de $1,1 \%$, seguindo duas direçōes principais na zona do Ayro, uma direção congruente com o curso do rio Uchusuma, e outro fluxo em direção à bacia adjacente, localizada na zona sul território chileno através de uma falha (F4) localizada nesta zona.

8- A qualidade físico-química das águas na sub-bacia variam no espaço quanto no tempo em função da época de estiagem ou de precipitação, essas mudanças observadas estão relacionadas a variáveis de :

- conteúdo de sais solúveis ionizados na água varia de valores de salinidade moderadamente alta $850 \mu \mathrm{S} / \mathrm{cm}$ a $1013 \mu \mathrm{S} / \mathrm{cm}$ (PA-7e PA-5 Zona de Laguna Blanca - Ayro) influenciadas por mistura com águas mineralizadas das zonas altas (Huayllata), decresce em direção NE a $112 \mu \mathrm{S} / \mathrm{cm}$ poço PA-6. Na zona de Charãna também observa-se esta variação de sul a 
norte, entre o poço P- 1 Est. Luripani $(600 \mu \mathrm{S} / \mathrm{cm}$ e $700 \mu \mathrm{S} / \mathrm{cm})$, e o poço 10 do local Tripartito $(100 \mu \mathrm{S} / \mathrm{cm}$ e $200 \mu \mathrm{S} / \mathrm{cm})$;

- pH varia de tendência ácida 5,13 medido no PA-5 (zona de Laguna Blanca), a valores neutros ou ligeiramente alcalinos 8,28 (PA-6). Na zona de Charaña os valores variam entre 7,2 na zona sul e $7,8(P-10)$ na zona norte, local de Tripartito;

- o grau de dureza varia desde água de alta dureza, no poço PA-5 (346 ppm), a moderada e baixa dureza (36,5 ppm no poço PA-6 a 272 ppm no poço PA-4;

- o perfil hidrogeoquímico determinado segundo o diagrama de Piper, as águas mostram um tendência bicarbonatada cálcica a sulfatada-cálcica. É importante ressaltar que as amostras analisadas da zona do Ayro correspondem a uma mistura de águas do aqüífero Maure e Capillune, devido a uma inter-relação hidráulica de fluxo nos diferentes poços profundos pelo tipo de projeto de poço encontrado, cuja zona de filtros abrange toda a espessura do poço;

- quanto à qualidade química das águas destinadas com fins de uso doméstico e irrigação, segundo os resultados de laboratório e comparadas com padrões correspondentes, podem ser consideradas, em termos de qualidade, como aceitável para o consumo doméstico por seu baixo conteúdo de cloretos, sulfetos e bicarbonatos. Porém, nas amostras analisadas de poços superficiais da zona de Charaña - Bolívia, detectouse a presença de Arsênio em concentrações entre 0,034 mg/L a 0,231 $\mathrm{mg} / \mathrm{L}$, que superam os limites permissiveis de $0,01 \mathrm{mg} / \mathrm{L}$ recomendadas pela USEPA (2002), o qual limita seu uso. Este resultado precisa de um estudo hidrogeoquimico especifico em toda a área por elementos menores, que permita determinar a origem do Arsênio e outros elementos tóxicos e suas possiveis relações com fontes de água mineralizada, tipo de rocha em contato, relações com zonas mineralizadas de Boro que é freqüente encontrar nestas áreas. Os resultados podem facilitar o isolamento de 
fontes naturais de contaminação ou propor diretrizes para um tratamento adequado;

- para uso na irrigação, segundo os indices estimados de (SAR), mostram valores baixos de 0,12 e um valor máximo de 2,35 evidenciando que não existe perigo de alcalinização do solo. Em termos gerais são águas de baixa a moderada salinidade $\mathrm{C}_{1} \mathrm{~S}_{1}, \mathrm{C}_{2} \mathrm{~S}_{1}$.

9.- Problemas ambientais gerados pela explotação das águas subterrâneas, determinou-se que estas são de caráter pontual em áreas reduzidas. As zonas afetadas com problemas de secagem encontram-se localizadas nas áreas baixas do ponto de captação do rio Uchusuma. Estas áreas degradadas estão circunscritas ao curso do vale rio Uchusuma que atravessa as planície de Humapalca próximo aos poços PA-4, PA-2, PA-1. Uma segunda área afetada encontra-se no território boliviano zona de Charaña o vale do rio Uchusuma mostra-se completamente seco em uma distância de aproximadamente $9 \mathrm{Km}$. A falta de dados históricos da abrangência de áreas hidromórficas, inviabiliza estimar as perdas econômicas ocasionadas pela explotação das águas superficiais.

10.- Para futuros planos que objetivem incrementar os volumes de exploração das águas subterrâneas da sub-bacia, recomenda-se que estas devam centrar-se na captação das águas do aqüifero profundo Maure, preservando deste modo efeitos negativos que afetem as áreas hidromórficas que são mantidas pelas variações do nível freático do aqüifero Capillune.

11.- Dentro do sistema as reservas de água subterrânea de caráter permanente atingem um volume estimado de $932,3 \times 10^{6} \mathrm{~m}^{3}$, que são responsáveis pela manutenção dos ecossistemas ao longo do deslocamento do rio Uchusma. As reservas reguladoras de caracter sazonal, atingem um volume de $20,6 \times 10^{6}$ $\mathrm{m}^{3}$ /ano. Com relação a esses dados estimou-se uma vazão de oferta $Q=1,8$ $\mathrm{m}^{3} / \mathrm{s}$, que pode ser gerenciada sem causar problemas de desequilibro ambiental e subsidiá-las nas demandas atuais e futuras.

12.- Devido à heterogeneidade sedimentar dos aqüíferos, para a fase de gerenciamento de águas subterrâneas recomenda-se realizar modelamentos de 
fluxos que permitam estabelecer os niveis de interferências entre os poços. Isto permitirá uma otimização dos recursos quanto a efetividade na exploração das águas, e além disso facilitará prognosticar o comportamento do nível de água em função ao tempo de bombeamento e seu impacto nas áreas hidromórficas. 


\section{FIGURA 37 - MODELO CONCEITUAL DO RESERVATÓRIO DA SUB-BACIA UCHUSUMA}

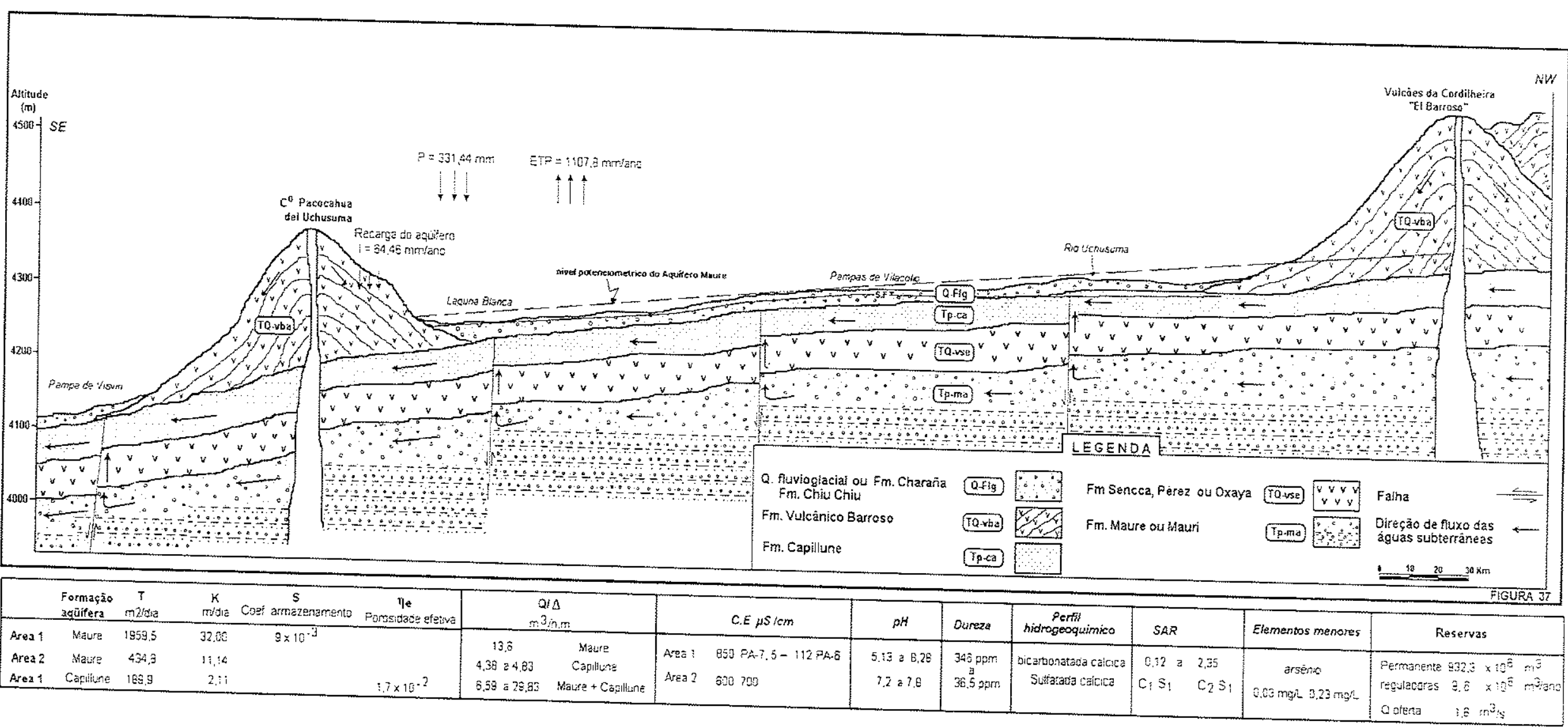




\section{REFERÊNCIAS BIBLIOGRÁFICAS}

AHLFELD, F.; BRANIZA, L. Geologia de Bolivia. La Paz: Instituto Boliviano del Petróleo, 1960. 245p.

ALT-AUTORIDAD BINACIONAL DEL LAGO TITICACA Estudio de la utilización de las aguas de la Cuenca Alta del Rio Maure. La Paz: ALT, 1988. 114p.

ALT-AUTORIDAD BINACIONAL DEL LAGO TITICACA Estudio hidrogeológico preliminar de la subcuenca del rio Uchusuma Perú. La Paz: ALT, 1996. 86p. (Relatório técnico).

AMORE, L.. Fundamentos para uso e proteção das águas subterrâneas do Distrito Federal São Carlos. São Paulo. 1994. 142p. Dissertação (Mestrado) Escola de Engenharia de São Carlos, Universidade de São Paulo, São Paulo.

APAZA, R. C. Estudo de potencialidade hídrica do aqüifero sedimentar da Formação Azángaro - área nordeste do Distrito de llave, Puno, Peru. São Paulo, Brasil. 1997. 108p. Dissertação (Mestrado) - Instituto de Geocienncias, Universidade de São Paulo, São Paulo.

ARANIBAR, O. (1995) Bloque Colchani-corregidores. La Paz: Yacimientos Petroliferos Fiscales Bolivianos YPFB. (Relatório interno)

ARANIBAR, O.; MARTINEZ, E. Structural interpretation of the Altiplano, Bolivia. In: FINAL WORKSHOP: STRUCTURE AND EVOLUTION OF THE CENTRAL ANDES IN NORTHERN CHILE, SOUTHERN BOLIVIA AND NORTHWESTERN ARGENTINA, 1990, Bolivia. Bolívia 1990, p. 47.

ASTIER, J. L. Geofisica aplicada a la hidrogeologia. Madrid: Paraninfo, 1975. $344 p$.

BLANCO, C. M. Evolución plio-cuaternaria de la cuenca de Charaña, Cordillera Occidental. La Paz, Bolivia.1980. 104p. Trábalo de Formatura - Facultad de Ciencias Puras, Departamento de Geociencias, Universidad Mayor de San Andrés. 
CANOVAS, C.J. Calidad agronómica de las aguas de Riego. 4.ed. España: Mundi Prensa, 1990. 57p.

CANTOS, F. J. Tratado de geofísica aplicada. 2 ed. Madrid: Litoprint, 1974. $520 \mathrm{p}$

CASTANY, G. Traité pratique des eaux souterraines. Paris: Dunod, 1967. 661p.

CAVALCANTE, I. N. Estudo hidrogeologico de terreno cristalino com manto de intemperismo - área Atibaia. São Paulo. 1990. 123p. Dissertação (Mestrado) Instituto de Geociências, Universidade de São Paulo.

COMISIÓN PARA LA COOPERACIÓN AMBIENTAL-CCA. (1997) Crisis ecológica en los Andes $y$ Respuesta, 1997. Disponível em: <http://csf.colorado.edu/mail/elan/ jun97/0022html Acesso em:30 março 2004

COSTA, S. A.. Águas subterrâneas: histórico e importância. In: FEITOSA, F. A.; FILHO, J. M. (coord.) Hidrogeologia conceitos e aplicações. Fortaleza: CPRM, 1997. 412p.

CUSTODIO, E. Hidroquímica. In: CUSTODIO, E.; LLAMAS, M. R. Hidrología Subterránea. 2. ed. Barcelona: Omega, 1996. p. 1003-1092.

CUSTODIO, E.; DIAZ, E. Calidad del agua subterranea In: CUSTODIO,E; LLAMAS,M.R. Hidrología subterránea. 2. ed. Barcelona: Omega, 1996. p. 18891896.

DALMAYRAC, B.; LAUBACHER, G.; MAROCCO, R. Características generales de la evolución geológica de los Andes Peruanos. Boletín. Instituto Geológico Minero y Metalúrgico. Serie D, n.12, p.1-313, 1988.

DHAR, R. K.; BISWAS,B.K; SAMANTA, G.; MANDAL, B. K.; CHAKRABORTI, D.; ROY, S.; JAFA, A.; ISLAM, A.; ARA, G.; KABIR, S.; KHAN, A. W.; AHMED, S. A.; HADI, A. S. Groundwater arsenic calamity in Bangladesh. Curr Sci India, v. 73, n. 1, p. $48-59,1997$. 
DOUGLAS, L. A. Geological sections through the Andes of Peru and Bolivia, part1 from the coast of Arica to La Paz and the Bolivia Yungas. Quartely Journal of Geological Society. London. v. 70, p.1-53, 1914.

DUARTE, C. W. Uso e gestão de águas subterrâneas. In: FEITOSA, F. A.; FILHO, J. M. (coord.) Hidrogeología conceitos e aplicaçóes. Fortaleza: CPRM, 1997. 412p.

FILHO, J. M. (1997) Ȧguas subterraneas: histórico e importância. In: FEITOSA, F. A.; FILHO, J. M. (coord.) Hidrogeología conceitos e aplicações. Fortaleza: CPRM, 1997. $412 p$.

FREEZE, R. A.; CHERRY, J. A. Ground water. New Jersey : Prentice-Hall, 1979. $604 p$.

GALLI, C.; DINGMAN, R. Cuadrángulo de Pica, Alca, Matilla y Chacarilla. In: Carta Geológica de Chile - Escala 1:250.000. Santiago:Instituto Investigación Geoogico, 1962.

GARCIA, Y. A. Prospección geofísica aplicada a la hidrogeología. In: CUSTODIO, E; LLAMAS, M. R. (ed.) Hidrología subterránea, 2.ed. Barcelona:Omega, 1996. v. 2 , p. $1391-1407$.

HEINRICHS, G; UDLUFT, P. 9) Natural arsenic in triassic rocks: a source of drinking-water contamination in Bavaria. Germany Hydrogeology, v. 7, n.5. p. 468-476, 1999.

HÉRAIL, G.; ROCHAT, P.; BABY, P.; ARANIBAR, O.; LAVENU, A.; MASCLEZ, G. (1997) El Altiplano Norte de Bolivia: evolución geológica terciaria. ORSTM: Departamento de Geologia. Universidad de Chile. Disponible em: $<$ http://mazinger.sisib.uchile.cl/repositorio/lb/ciencias veterinariasypecuarias/simp osio $1993 / 01$ areacienciasdelatierra/11.html > acesso em out. 2003

HOLLINGWORT, H. S. E.; RUTLAND, R.W.R. Studies of Andean uplift; postcretaceous evolution of the San Bartolo area, northern Chile. Geological Journal, v. 6. p. 49-62, 1968. 
HOUNSLOW, A. W. Water quality data, analysis and interpretation. New York: Lewis, 1995. 397p.

INGEMMET - INSTITUTO GEOLÓGICO MINERO METALÚRGICO Evaluación de la zonas hidrotermales del area de Kallapuma y alrededores. Lima: INGEMMET, 1995. 136p.

INGEMMET-INSTITUTO GEOLÓGICO MINERO METALÚRGICO Mapa geológico: hoja -PALCA. Lima: INGEMMET, 1998. (Escala 1:100.000).

INGEMMET-INSTITUTO GEOLÓGICO MINERO METALÚRGICO Mapa geológico: hoja Maure. Lima: INGEMMET, 1998. (Escala 1:100.000)

INGEMMET-INSTITUTO GEOLÓGICO MINERO METALÚRGICO. Mapa geológico hoja Antajave. Lima: INGEMMET, 1998. (Escala 1:100.000).

INSTITUTO NACIONAL DE ESTADÍSTICA E INFORMÁTICA - INEI. Resultados definitivos de los censos nacionales. In: CENSO NACIONAL DE POBLACIÓN $Y$ IV DE VIVIENDA, 9., 1993. Lima. Lima: INEI, 1994. V. Tacna (23)

INSTITUTO NACIONAL DE DESARROLLO - PROYECTO ESPECIAL TACNA. Recursos hídricos subterráneos, acuifero ayro. Tacna: INDE-PET, 1993. 57p.

JONHSON, E. E. Águas subterrâneas e poços tubulares. 3. ed. São Paulo: CETESB, 1978. $482 p$.

KLINCK, B. A.; ALLISON, R. A.; HAUEKINS, N. P.; PALACIOS, O. Geología de la cordillera occidental y altiplano al oeste del lago Titicaca - sur del Perú. Boletín. Instituto Geológico Minero y. Serie A, n.42, p.1-257, 1993.

KORTE, N. E.; FERNANDO, Q. A review of arsenic III in groundwater. Critical Reviews in Environmental Control, v.21, p.1-39, 1991.

KRUSEMAN, G. P.; RIDDER, N. A. Analysis and evaluation of pumping test data. Bulletin. International Institute for Land Reclamation and Improvement, n.11, p.1-200, 1970. 
LAUBACHER, G. Estudio geológico de la región norte de Lago Titicaca. Boletín.Instituto Geológico Minero y Metalúrgico. Serie D, n.5, p.1-120, 1978.

LAVENU, A. Formación geológica y evolución. In: DEJOUX, C.; ILTIS, A. El lago Titicaca sintesis del conocimiento limnológico actual. La Paz: ORSTOM HISBOL, 1992. p. 19-27.

LAVENU, A.; FORNARI, M.; SEBRIER, M. Existence de deux nouveaux épisodes lacustres quaternaires dans Altiplano péruvo-bolivien. Bolivia, Cahiers ORSTOM. Serie Geologie, v.14, n.1, p.103-114, 1984.

LAVENU, A. Origine et Évolution Néotectonique du Lac Titicaca, La Paz, Bolivia. Rev. Hydrobio/Trop 14 (4): p. 289-297, 1981

LUQUE, J. A. Hidrología agricola aplicada. Buenos Aires: Hemisferio Su, 1981. $356 p$.

MARTINEZ, C. L.; SERRANO, G. Nuevos datos geocronológicos y bioestratigráficos del macizo antiguo de Arequipa. In: CONGRESO PERUANO DE GeOlogíA, 9., Lima, Peru 1997. Resúmenes. Lima : Sociedad Geológica del Perú, 1997. v. 1, p. 365 - 369.

MARTINEZ, C. L.; HEUSCHMIDT, B. Evolución tectónica y diferenciación magmática de la caldera de Guacha, sudoeste de Bolivia. In: CONGRESO GEOLÓGICO CHILENO, 7.,. 1994, Cocepcion. Resúmenes. Concepción, Chile, 1994. v. 1, p. $112-116$.

MARTINEZ, C. L. Structure et évolution de la chaine hercynienne et de la chaine Andine dans le nord de la Cordillère des Andes de Bolivie. Travaux et Documents de L"ORSTOM, n.119, p.1-352, 1980.

MEGAR, F. Informe geológico de Laguna Ariscota Valle del rio Caplina, Quebrada Palca - Quebrada Vilavilani, Rio Maure y Laguna Lariscota. Tacna, Perú: Dirección de industrias y Electricidad-División de Obras Elétricas del Departamento de Tacna, 1961.97p. (Relatório interno)

MENDIVIL, E. S. Estratigrafia sedimentaria y volcanica del terciario en la Faja Costanera del Sur del Perú. Arequipa. Peru: UMSA, 1977. v.2., 47p. 
MENDIVIL, S. Geología de los cuadrángulos de Maure a Antajave. Boletín.Instituto Geológico Minero y Metalúrgico.Serie A, Carta Geológica Nacional, v.10, p.1-97, 1965.

MIRANDA, G.; CHÁVEZ, R.; ARGOLLO, J.; FIGUEROA, F. Dinámica de las precipitaciones pluviales en el Altiplano Boliviano. In: SIMPOSIO NACIONAL DE CAMBIOS GLOBALES., La Paz, 2000. Boletin de Resúmenes. La Paz, Bolívia, Academia Nacional de Ciências, 2000, p. $84-91$.

MORAIS, N. E. Sensoreamento remoto principios e aplicações. 2. ed. São Paulo: Edgard Blucher, 1998. 308p.

MOYRA, G. P.; RAMIREZ, C. F. Vulcanismo cenozoico superior del Altiplano Chileno. Santiago de Chile: SERNAGEOMIN, 1985. p. E1-E30.

NARANJO, A.; PASKOFF, R. (1981) Estratigrafia de los depósitos Cenozoicos de la Región de Chiuchiu-Calama, desierto de Atacama. Revista Geologica do Chile, n.13. p. $78-85,1981$.

NEWELL, N. D. Geology of the lake Titicaca Region Puno and Bolivia. Geological Society of America. Memoir, v. 36. p. 3-111, 1949.

NÚNEEZ, W. R. Estudio geológico de la zona de Charaña, Eduardo Abaroa, General Pérez. La Paz, Bolívia, 1964. 53p. Trábalo de Formatura - Facultad de Ciencias Geológicas, Universidad Mayor de San Andrés.

ORGANIZACION MUNDIAL DE LA SALUD International standards for drinking water. 2. ed. Geneva: World Health Organization, 1963. 206p.

PARANIS, D. S. Principles of applied geophysics. New York: Chapman \& Hall, 1986. $402 p$.

PASKOFF, R.; NARANJO, A. Formation et evolution du piémont andin dans le désert du nord du Chile $\left(18^{\circ}-21^{\circ}\right.$ latitude Sud) pendant le cénizoique superior. Comptes Rendus Academie Science. Serie 11, n 294, p. 743-748, 1983.

PELT-PROYECTO ESPCIAL LAGO TITCACA Plan director binacional de protección, prevención de inundaciones y aprovechamiento de los recursos del 
lago Titicaca, Rio Desaguadero, Lago poopo y Salar de Coipasa (Sistema TDPS) - Climatología. La Paz: PELT, 1993. 130p.

PEREZ, V. G. (1979) El Acuífero Maure y el Problema de la Escasez de agua en la ciudad de Tacna. In: Sociedad Geológica del Perú. v. 63, n.4, p.179-194, 1979.

PRENSA 12 de Mayo de 1999. Parlamento del Pueblo Aymara; defensa del Agua del Altiplano, la ecologia y el medio ambiente de la cuenca Andina - consejo de Mallkus y Amautas. La Paz: (CMA-PPA) Disponivel em: <http://www.lica.org.uy/16-6-pan3-pon10.htm> Acesso em: 30-03-04

PRESENCIA 6 Dezembro 2000 La Paz. Instituto Internacional de Cooperación para la Agricultura - IICA. Disponivel em: <http://www.aguabolivia.org/ prensaX/Prensa/2000/Diciembre/2 DRa061200.htm> Acesso em: 30-03-04.

REBOUÇAS, A. Gestão sustentável dos grandes Aqüiferos. In: VIII CONGRESSO BRASILEIRO DE ÁGUAS SUBTERRÂNEAS, . Recife, 1994. Anais. Recife, ABAS, 1994. p. $131-139$.

REBOUÇAS, A.; RICCOMINI, C.; ELLLERT, N.; DUARTE, U.; MELLITO, K.; SENF, L.; SIMANKE, S. Diagnóstico hidrogeológico da RMSP - uso e proteção. In: VIII CONGRESSO BRASILEIRO DE ÁGUAS SUBTERRÂNEAS. Recife, 1994. Anais. Recife, ABAS, 1994. p. 93 - 102.

REBOSIO, A. Análisis del Proyecto de Aguas, Ley D.S. 122-2002-PCM. Lima: Centro de Investigacion, Educacion y Desarrollo-CIED, 2003. (Relatório Agualtiplano: Lima 05-maio 2003)

ROEDER, D. Andean age structure of eastern Cordillera. Tectonics, v.7, n.1, p. 23-39, 1988 .

SALAS, R.; KAST, F.; MONTECINOS, F. Geologia y recursos minerales del departamento de Arica, Provincia de Tarapacá. Santiago, Chile, Inst. Invest. Geol. v. 21. 14p, 1966. 
SEMPERE, T.; HÉRAIL, G.; OLLER, J.; BABY, P.; BARRIOS, L.; MAROCCO, R. The Altiplano: a province of intermontane foreland basins related to crustal shortening in the Bolivian Orocline area. In: SYMPOSIUM INTERNATIONAL GEODYNAMIQUE ANDINE. Paris: ORSTOM, 1990. p. $1676-170$.

SERVICIO DE GEOLOGIA Y MINERÍA Mapa geológico hoja de Charaña. La Paz: SERGEOMIN, 1963. (Escala 1:100.000).

SERVICIO NACIONAL DE GEOLOGIA Y MINERIA Mapa geológico de la región de Tarapacá. Santiago de Chile: SERNAGEOMIN, s.d. (Escala 1:250.000).

SERVICIO NACIONAL DE GEOLOGIA Y MINERIA - CHILE Mapa metalogénico de la región Fronteriza entre Argentina, Bolivia, Chile y Perú (14 $\left.S-28^{\circ} S\right)$. Publicación Geológica Multinacional. Santiago : OGAR, 2001, n. 2., p.1-222.

SIRVAS, F; TORRES, E. Consideraciones geológicas de la parte noroeste de la Provincia de Pacajes del Departamento de La Paz. Bolivia. Instituto Boliviano del Petróleo, v. 6, 1, p. $54-64,1966$.

SIRVAS, J. F. Estudio geológico de la región Tambo Maud-Berenguela. Provincia Pacajes. La Paz, Bolivia. 1964. 84f. Trábalo de Formatura - Facultad de Ciencias Geológicas, Universidad Mayor de San Andrés.

STAUFFER, R. E.; THOMPSON, F. M. Arsenic and antimony in geothermal waters of Yellowstone National Park, Wyoming, USA. Geochimica et Cosmochimica Acta, v. 48, p. 2547-2561, 1984.

STEINMULLER, K; ZAVALA, B. Hidrotermalismo en el sur del Perú. Boletín.Instituto Geológico Minero y Metalúrgico.Serie D, n.18, p.1-79, 1997.

SZIKSZAY, M. Geoquímica das águas. Boletim IG-USP. Série Didática, v.5, p.1166, 1993.

TUBELIS, A.; LINO, F. J. Meteorología descriptiva fundamentos e aplicações brasileiras. 5.ed. São Paulo: Nobel, 1987. 374p. 
TUCCl, C. E.; BELTRAME, L.. F. Evaporação e evapotranspiração. In: TUCCI, C. (org.) Hidrologia ciência e aplicação. Porto Alegre: ABRH/EDUSP, 1993. v. 4. p. 253 - 277. (Coleção ABRH de Recursos Hídricos)

UNESCO Guía metodologica para la elaboración del balance hídrico de América de/ Sur. Montevidéu: ROSTLAC, 1982. 130p.

USEPA- UNITED STATES ENVIRONMENTAL PROTECTION AGENCY Ambient water quality criteria for arsenic. Washington: USEPA, 1980. (EPA. 440/5-80021).

USEPA-UNITED STATES ENVIRONMENTAL PROTECTION AGENCY Implementation guidance for the arsenic rule - drinking water regulations for arsenic and clarifications to compliance and new source contaminants monitoring, 2002. 83p. Disponivel em:<http://www.epa.gov/safewater/ars/ pdfs/regguide lars_final_!mainguide_9-13.pdf> Acesso em: 29-03-04

VILLANUEVA, M. M.; IGLESIAS, L. A. Pozos y acuiferos, tecnicas de evaluación mediante ensayos de bombeo. Madrid: Ibergesa, 1984. 425p.

WELCH, A. H.; LICO, M. S.; HUGHES, J. L. Arsenic in groundwater of the western United States, U.S. Ground Water, v. 26 n.3. p. 333-347, 1988.

WILSON, J. J.; GARCIA, W. Geología de los cuadrángulos de Pachia y Palca Boletín. Comision Carta Geológica Nacional.Lima- Perú, Serie A, v.2, n.4, p.1-82, 1962. 
S $O X \exists N \forall$ 


\section{ANEXO I}

DADOS DE PRECIPITAÇÃO MÉDIA MENSAL

\section{ESTAÇÃO METEOROLÓGICA PAUCARANI - TACNA PERU}

Período 1960 - 1998

\begin{tabular}{|c|c|c|c|c|c|c|c|c|c|c|c|c|c|}
\hline Ano & Jan & $\mathrm{FeV}$ & Mar & $\mathrm{Abr}$ & $\mathrm{Mai}$ & Jun & Jul & Ago & Set & Out & Nov & Dez & Total \\
\hline 1960 & 17,30 & 39,00 & 36,00 & 0,00 & 0,00 & 0,00 & 0,00 & 0,00 & 3,00 & 4,00 & 40,00 & 50,00 & 189,30 \\
\hline 1961 & 130,00 & 138,00 & 61,00 & 2,00 & 10,00 & 0,00 & 0,00 & 0,00 & 6,00 & 10,00 & 79,00 & 118,00 & 654,00 \\
\hline 1962 & 49,00 & 63,00 & 82,00 & $\$ 0,00$ & 0,00 & 0,00 & 0,00 & 0,00 & 4,00 & 37,00 & 43,00 & 85,00 & 373,00 \\
\hline 1963 & 59,00 & 64,00 & 70,00 & 5,00 & 0,00 & 0,00 & 0,00 & 0,00 & 7,00 & 64,00 & 7,00 & 54,00 & 330,00 \\
\hline 1964 & 69,00 & 66,00 & 57,00 & 0,00 & 1,00 & 0.00 & 0,00 & 9,00 & 1,00 & 6,00 & 26,00 & 26,00 & 261,00 \\
\hline 1965 & 70,00 & 91,00 & 58,00 & 11,00 & 3,00 & 4,00 & 4,30 & 6,00 & 20,10 & 0,00 & 3,50 & 46,90 & 317,80 \\
\hline 1966 & 15,40 & 81,20 & 55,20 & 2,20 & 30,80 & 0,80 & 0,00 & 0,00 & 0,00 & 20,9 & 23,60 & 38,10 & 268,20 \\
\hline 1967 & 67,90 & 138,00 & 133,70 & 23,3 & 0,00 & 2,50 & 6,50 & 3,50 & 12,80 & 3,90 & 4,30 & 77,80 & 474,20 \\
\hline 1968 & 98,20 & 104,10 & 101,00 & 20,80 & 12,00 & 3,30 & 0,50 & 0,50 & 3,00 & 24,50 & 61,50 & 30,30 & 459,70 \\
\hline 1969 & 83,50 & 76,00 & 78,30 & 5,50 & 0,00 & 2,00 & 0,00 & 2,00 & 12,20 & 1,00 & 23,80 & 93,80 & 378,10 \\
\hline 1970 & 111,80 & 56,30 & 43,50 & 10,00 & 13,50 & 0,00 & 2,00 & 4,00 & 1,00 & 5,20 & 0,00 & 45,30 & 292,60 \\
\hline 1971 & 114,70 & 136,00 & 53,00 & 3,30 & 0,00 & 1,00 & 0,00 & 0,00 & 0,00 & 0,50 & 19,10 & 54,70 & 382,30 \\
\hline 1972 & 176,80 & 120,90 & 116,20 & 24,60 & 0,00 & 0,00 & 0.00 & 0,00 & 8,70 & 13,00 & 7,90 & 72,00 & 540,10 \\
\hline 1973 & 195,90 & 93,20 & 106,30 & 23,90 & 0,00 & 0,00 & 0,00 & 3,50 & 4,00 & 1,50 & 14,20 & 0,00 & 442,50 \\
\hline 1974 & 238,30 & 110,80 & 0,00 & 0,00 & 0,00 & 3,00 & 1,00 & 64,50 & 1,80 & 1,00 & 0,00 & 20,70 & 441.10 \\
\hline 1975 & 127,80 & 145,20 & 131,90 & 7,50 & 3,00 & 1,50 & 0,00 & 0,00 & 1,00 & 0,00 & 0,00 & 138,50 & 556,40 \\
\hline 1976 & 166,80 & 111,80 & 16,90 & 1,40 & 1,00 & 0,00 & 0,50 & 3,00 & 10,00 & 0,00 & 0,00 & 31,90 & 342,50 \\
\hline 1977 & 94,30 & 170,30 & 96,00 & 8,20 & 6,00 & 0,00 & 9,20 & 0,00 & 6,30 & 7,00 & 39,30 & 67,20 & 503,80 \\
\hline 1978 & 172,80 & 41,50 & 31,20 & 12,80 & 0,00 & 0,00 & 0,10 & 0,20 & 0,00 & & 62,30 & & 375,50 \\
\hline 1979 & 91,40 & 16,30 & 71,70 & 0,10 & 0,00 & 0,00 & 1,80 & 0,00 & 0,00 & 13,80 & 5,10 & 31,70 & 231,90 \\
\hline 1980 & 30,80 & 34,20 & 80,30 & 1.20 & & & 1,20 & 0,00 & 0,00 & 41,70 & 0,00 & 23,80 & 213,20 \\
\hline 1981 & 87,70 & 165,40 & 52,50 & 34,80 & 0,00 & 0,00 & 0,00 & 5,70 & 52,10 & & 28,90 & 93,00 & 522,40 \\
\hline 1982 & $\uparrow 37,00$ & 59,00 & 35,90 & 40,40 & 1,20 & 4,10 & 0,00 & 0,00 & 20,90 & 38,70 & 63,60 & 46,60 & 447,40 \\
\hline 1983 & 5,60 & 16,20 & & & & & 0,00 & 3,70 & 10,30 & 0,00 & 0,00 & 30,10 & 65,90 \\
\hline 1984 & 161,30 & 257,40 & 137,60 & 3,60 & 0,00 & 19,20 & 0,10 & 0,20 & & & 50,70 & 12,60 & 688,60 \\
\hline 1985 & 65,20 & 220,60 & 49,40 & 18,80 & 0,00 & 16,20 & 0,00 & 1,00 & 2,30 & 0,00 & 110,40 & 104,90 & \\
\hline 1986 & 140,60 & 133,70 & 99,20 & 23,90 & 3,60 & 0,00 & 2,70 & 9,10 & 0,00 & 0,00 & 14,20 & 179,80 & 606,80 \\
\hline 1987 & 126,00 & 4,80 & 0,00 & 0,00 & 5,00 & 9,30 & 64,70 & 0,00 & 0,00 & 0,00 & 0,00 & 0,00 & 209,80 \\
\hline 1988 & 115,40 & 8,00 & 63,20 & 5,00 & 0,00 & 0,00 & 0,00 & 0,00 & 2,00 & 0,00 & 0,00 & 55,40 & 249,00 \\
\hline 1989 & 87,30 & $\$ 23,50$ & 179,50 & 39,50 & 0,00 & 0,00 & 3,50 & 0,00 & 0.00 & 0,00 & 0,00 & 0,00 & 433,30 \\
\hline 1990 & 114,00 & 16,80 & 62,30 & 7,50 & 13,50 & 61,80 & 0,00 & 0,00 & 0,00 & 0,00 & 6,20 & 104,80 & 386,90 \\
\hline 1991 & 99,00 & 40,00 & 49,00 & 11,00 & 0,00 & 27,00 & 0,00 & 0,00 & 0,00 & 0,00 & 34,70 & 0,00 & 260,70 \\
\hline 1992 & 63,50 & 0,00 & 0,00 & 0,00 & 0,00 & 9,50 & 0,00 & 11,50 & 0,00 & 0,00 & 31,50 & 74,10 & 190,10 \\
\hline 1993 & 226,50 & 19.80 & 113,00 & 0,00 & 0,00 & 7,90 & 0,00 & 13,00 & 0,00 & 10,50 & 16,00 & 43,80 & 450.50 \\
\hline 1994 & 115,60 & 201,80 & 86,80 & 26,50 & 0,00 & 0.00 & 0,00 & 0,00 & 3,10 & 0,00 & 25,00 & 45,40 & 504,20 \\
\hline 1995 & 52,80 & 33,70 & 86.50 & 8,20 & 3,40 & 0,00 & 0,00 & 0,00 & 0,00 & 1,80 & 10,50 & 34,00 & 230,90 \\
\hline 1996 & 120,00 & 68,70 & 35,30 & 12,30 & 5,00 & 0,00 & 0,00 & 0,30 & 0,00 & 0,00 & 23,90 & 31,70 & 297,20 \\
\hline 1997 & 153,60 & 179,40 & 52,10 & 78,00 & 32,00 & 2,00 & 0,00 & 0,00 & 1,00 & 7,00 & 0,00 & 31,00 & 536,10 \\
\hline 1998 & 103,00 & 86,00 & 32,00 & 8,00 & 0,00 & 0,00 & 0,00 & 0,10 & 0,00 & 1,90 & 18,00 & 36,00 & 285,00 \\
\hline led & 106,63 & 90,66 & 67,93 & 12,69 & 3,79 & 4,61 & 2,58 & 3,78 & 5,09 & 9,85 & 23,05 & 53,44 & 384,11 \\
\hline
\end{tabular}




\title{
ANEXO I
}

\section{DADOS DE PRECIPITAÇÃO MÉDIA MENSAL}

\author{
ESTAÇÃO METEOROLÓGICA CHARAÑA -LA PAZ - BOLIVIA \\ Periodo 1960 - 1998 Fonte SENAMHI - PER
}

\begin{tabular}{|c|c|c|c|c|c|c|c|c|c|c|c|c|c|}
\hline Ano & Jan & Fev & Mar & $\mathrm{Abr}$ & Mai & Jun & Jul & Ago & Set & Out & Nov & Dez & Total \\
\hline 1960 & 132,80 & 32,10 & 8,00 & 3,90 & 0,00 & 0,00 & 0,00 & 25,00 & 21,00 & 4,90 & 12,20 & 16,00 & 255,90 \\
\hline 1961 & 105,60 & 94,50 & 45,80 & 6.00 & 4,40 & 1,40 & 0,00 & 0,00 & 5,60 & 6.80 & 56,20 & 90,90 & 417,20 \\
\hline 1962 & 64,30 & 74,80 & 35,50 & 27,70 & 0,00 & 0,00 & 0,00 & 0,00 & 2,10 & 0,00 & 13,80 & 54,40 & 272,60 \\
\hline 1963 & 69,60 & 92,20 & 71,00 & $\$ 1,10$ & 3,20 & 0,00 & 8,10 & 1,70 & 2,50 & 7.60 & 7,20 & 20,50 & 294,70 \\
\hline 1964 & 23,10 & 37,10 & 13,50 & 4,50 & 1,40 & 0,00 & 0,00 & 1,80 & 0,00 & 1,00 & 9,00 & 21,80 & 113,20 \\
\hline 1965 & 34,10 & 167.56 & 28,83 & 0,00 & 0,00 & 0,00 & 0,00 & 0,60 & 25,00 & 0,00 & 0,00 & 30.70 & 286,79 \\
\hline 1966 & 13,16 & 81,83 & 27,31 & 0,34 & 9,85 & 0,00 & 0,06 & 0,00 & 0,01 & 12,11 & 29,20 & 30,85 & 204,72 \\
\hline 1967 & 47.25 & 106,41 & 20,26 & 12,03 & 0,32 & 0.55 & 0,00 & 0,43 & 0,81 & 17,77 & 60,47 & 58,79 & 325,09 \\
\hline 1968 & 106,30 & 117,60 & 74,70 & 1,70 & 23,60 & 9,80 & 0,00 & 0,00 & 7,00 & 46,10 & 81,00 & 45,50 & 513,30 \\
\hline 1969 & 75,30 & 48,70 & 37,70 & 0,00 & 0,00 & 0,00 & 0,00 & 0,00 & 0,00 & 0,00 & 5,80 & 38,40 & 205,90 \\
\hline 1970 & 89,70 & 52,50 & 81,00 & 10,60 & 1,40 & 0,00 & 0,00 & 0,00 & 0,00 & 11,70 & 2,10 & 30,30 & 279,30 \\
\hline 1971 & 110,80 & 134,50 & 25,70 & 3,30 & 0,00 & 0,00 & 0,00 & 0,00 & 0,00 & 0,00 & 30,70 & 39,60 & 344,60 \\
\hline 1972 & 155,80 & 88,60 & 82,40 & 44,80 & 0,00 & 0,00 & 0,00 & 0,00 & 2,20 & 8,70 & 0,00 & 80,40 & 462,90 \\
\hline 1973 & 175,70 & 111,40 & 79,30 & 17,30 & 0,00 & 0,00 & 4,40 & 18,40 & 8,20 & 4,20 & 0,70 & 19,20 & 438,80 \\
\hline$\uparrow 974$ & 254,20 & 94,10 & 30,70 & 15,30 & 0,00 & 0,00 & 0,00 & 108,20 & 0,80 & 0,00 & 1,40 & 7,60 & 512,30 \\
\hline 1975 & $\$ 48,80$ & 110,00 & 84,00 & 4,70 & 10,90 & 0,00 & 0,00 & 0,00 & 0,00 & 1,80 & 0,00 & 138,30 & 498,50 \\
\hline 1976 & 143,00 & 78,60 & 42,30 & 11,30 & 0,00 & 0,00 & 0,80 & 4,80 & 8,80 & 0,00 & 0,00 & 58,00 & 347,60 \\
\hline 1977 & 92,56 & 158,40 & 70,80 & 2,00 & 2,80 & 0,00 & 0,00 & 0,00 & 8,30 & 29,50 & 31,90 & 78,50 & 474,76 \\
\hline 1978 & 172,00 & 19,90 & 70,80 & 21,40 & 0,00 & 0,00 & 2,30 & 2,30 & 0,00 & 21,10 & 59,90 & 45,20 & 414,90 \\
\hline 1979 & 146,00 & 4,50 & 98,60 & 0,60 & 0,00 & 0,00 & 0,00 & 0,00 & 0,00 & 7,50 & 4.30 & 38,50 & 300,00 \\
\hline 1980 & 32,80 & 23,70 & 93,30 & 0,00 & 0,00 & 0,00 & 0,00 & 0,00 & 0,00 & 0,00 & 0,00 & 0,00 & 149,80 \\
\hline 1981 & 70,00 & 93,27 & 29,80 & 4,40 & 0,00 & 0,00 & 0,00 & 30,20 & 0,00 & 0,00 & 13,20 & 14,60 & 255,47 \\
\hline 1982 & 69,93 & 34,40 & 59,80 & 3,20 & 0.00 & 0,00 & 0,00 & 0,00 & 1,00 & 65,10 & 8,00 & 13,00 & 254,43 \\
\hline 1983 & 14,40 & 20,40 & 0,00 & 0,00 & 0,00 & 0,00 & 0,00 & 0,00 & 0,00 & 3,80 & 2,60 & 26,60 & 67,80 \\
\hline 1984 & 125,60 & 124,80 & 144,70 & 0,00 & 0,00 & 0,00 & 0,00 & 0,00 & 0,00 & 24,80 & 90,40 & 6,00 & 516,30 \\
\hline 1985 & 89,20 & 164,20 & 72,20 & 14,00 & 2,00 & 12,10 & 0,00 & 0,00 & 1,00 & 0,00 & 129,40 & 50,10 & 534,20 \\
\hline 1986 & 117,80 & 52,00 & 121,20 & 24,00 & 0,00 & 0.00 & 0,00 & 3,70 & 0,00 & 7,80 & 5,50 & 98,80 & 430,80 \\
\hline 1987 & 149.50 & 29.90 & 18.50 & 0,00 & 0,00 & 1,00 & 1,60 & 5,40 & 0,00 & 13,40 & 6,30 & 8,80 & 234,40 \\
\hline 1988 & 106,40 & 20,20 & 49,60 & 49,30 & 1,30 & 0,00 & 0,00 & 0,00 & 0,00 & 7,52 & 1,94 & 31,32 & 267,58 \\
\hline 1989 & 81,70 & 68,50 & 47,30 & 66,00 & 0,00 & 2,00 & 0,00 & 0,00 & 0,00 & 0,00 & 0,20 & 0,00 & 265,70 \\
\hline 1990 & 66,00 & 10,90 & 17,90 & 6.60 & 4,30 & 28,50 & 0,00 & 0,30 & 0,00 & 10,90 & 21,80 & 76,90 & 244,10 \\
\hline 1991 & 107,00 & 82,00 & 85,00 & 9,00 & 0,00 & 1,00 & 0,00 & 10,00 & 0.00 & 2,00 & 99,00 & 0,00 & 395,00 \\
\hline 1992 & 81,00 & 25,00 & 4.00 & 0,00 & 0,00 & 1,00 & 2,00 & 0,00 & 1,00 & 15,00 & 81,00 & 57,00 & 267,00 \\
\hline 1993 & 275,00 & 41,00 & 91,00 & 0,00 & 0,00 & 0,00 & 0,00 & 2,00 & 0,00 & 9,00 & 27,00 & 16,00 & 461,00 \\
\hline 1994 & 66,00 & 157,00 & 85,00 & 36,00 & 0,00 & 0,00 & 0,00 & 0.00 & 0,00 & 29,00 & 14,00 & 13,00 & 400,00 \\
\hline 1995 & 63,00 & 28,00 & 17,00 & 17,00 & 9,00 & 1,00 & 0,00 & 0,00 & 0,00 & 4,00 & 6,00 & 36,00 & 181,00 \\
\hline 1996 & 95,00 & 54,00 & 45,00 & 1,00 & 0,00 & 0,00 & 0,00 & 2,00 & 1,00 & 1,00 & 2,00 & 55,00 & 256,00 \\
\hline 1997 & 123,00 & 168,00 & 91,00 & 35,00 & 16,00 & 0,00 & 0,00 & 0,00 & 0,00 & 4,00 & 0,00 & 14,00 & 451,00 \\
\hline 1998 & 123,00 & 76,00 & 28,00 & 3,00 & 0,00 & 0,00 & 0,00 & 0,50 & 0,00 & 1,40 & 11,00 & 32,00 & 275,00 \\
\hline Ved & 102,40 & 76,40 & 55,10 & 12,00 & 2,15 & 1,50 & 0,50 & 5,70 & 2,45 & 9,95 & 24,06 & 38,40 & 331,40 \\
\hline
\end{tabular}




\title{
ANEXO I
}

\section{DADOS DE PRECIPITAÇÄO MÉDIA MENSAL}

\author{
ESTAÇÃO METEOROLÓGICA ABAROA - LA PAZ - BOLIVIA \\ Periodo 1960 - 1997 Fonte SENAMHI - BOLIVIA
}

\begin{tabular}{|c|c|c|c|c|c|c|c|c|c|c|c|c|c|}
\hline Ano & Jan & Fev & Mar & $A b r$ & Mai & Jun & Jul & Ago & Set & Out & Nov & Dez & Total \\
\hline 1960 & 169.10 & 42.60 & 18.50 & 1.80 & 0.50 & 0.00 & 0.00 & 1.70 & 1.50 & 7.90 & 62.60 & 16.90 & 323.10 \\
\hline 1961 & 87.50 & 66.30 & 39.20 & 3.20 & 0.60 & 0.70 & 0.00 & 1.30 & 1.30 & 0.80 & 29.90 & 89.30 & 320.10 \\
\hline 1962 & 56.00 & 94.00 & 39.20 & 9.30 & 0.00 & 0.00 & 0.10 & 0.00 & 1.50 & 1.10 & 11.80 & 67.90 & 280.90 \\
\hline 1963 & 71.40 & 112.90 & 59.40 & 8.20 & 0.00 & 0.50 & 0.10 & 0.70 & 2.70 & 2.40 & 11.00 & 22.10 & 291.40 \\
\hline 1964 & 26.90 & 48.80 & 22.90 & 7.60 & 8.40 & 0.10 & 0.00 & 5.60 & 0.80 & 0.10 & 0.50 & 28.70 & 150.40 \\
\hline 1965 & 42.50 & 11.90 & 26.90 & 7.50 & 0.20 & 0.00 & 0.10 & 0.00 & 0.40 & 11.10 & 5.10 & 30.00 & 137.70 \\
\hline 1966 & $\$ 6.10$ & 82.40 & 19.70 & 0.50 & 0.60 & 0.00 & 0.20 & 0.00 & 0.40 & 10.90 & 26.30 & 25.70 & 182.80 \\
\hline 1967 & 48.50 & 91.20 & 20.70 & 9.50 & 0.00 & 0.00 & 0.00 & 0.00 & $\$ .20$ & 12.10 & $52 . .30$ & 39.40 & 244.90 \\
\hline 1968 & 74.20 & 16.70 & 26.00 & 2.90 & 0.60 & 6.80 & 0.00 & 0.00 & 1.20 & 26.60 & 92.50 & 24.30 & 371.80 \\
\hline 1969 & 82.90 & 46.80 & 28.40 & 0.00 & 0.00 & 0.50 & 0.70 & 0.50 & 0.00 & 0.10 & 0.30 & 41.30 & 204.50 \\
\hline 1970 & 92.70 & 59.50 & 75.40 & 18.00 & 0.40 & 0.00 & 0.10 & 0.10 & 0.20 & 1.80 & 10.00 & 46.60 & 304.80 \\
\hline 1971 & 80.40 & 96.20 & 28.20 & 0.20 & 1.00 & 0.00 & 0.00 & 14.00 & 0.00 & 0.00 & 4.50 & 34.00 & 259.50 \\
\hline 1972 & $13^{*} 9.90$ & 76.20 & 109.70 & 31.20 & 0.00 & 0.00 & 0.00 & 0.00 & 12.20 & 21.80 & 16.00 & 71.20 & 478.20 \\
\hline 1973 & 153.00 & 135.20 & 36.50 & 6.60 & 0.40 & 0.00 & 0.00 & 15.10 & 4.80 & 6.30 & 1.00 & 21.60 & 380.50 \\
\hline 1974 & 250.10 & 164.90 & 41.00 & 12.00 & 0.00 & 0.00 & 0.00 & 64.80 & 3.50 & 0.00 & 14.30 & 19.40 & 570.00 \\
\hline 1975 & 128.20 & 134.50 & 71.30 & 4.50 & 6.50 & 0.00 & 0.00 & 0.00 & 2.00 & 1.00 & 0.00 & 72.50 & .50 \\
\hline 1976 & $\$ 12.50$ & 68.50 & 3020 & 5.70 & 2.50 & 0.00 & 1.00 & 2.50 & 7.00 & 0.00 & 0.00 & 293.20 & 258.70 \\
\hline 1977 & 56.20 & 124.60 & 96.40 & 9.90 & 2.90 & 0.00 & 0.00 & 0.00 & 0.30 & 27.50 & 39.00 & 36.80 & 393.60 \\
\hline 1978 & 100.70 & 11.70 & 17.30 & & 0.00 & 0.00 & 0.00 & 0.50 & 0.00 & 0.00 & 32.40 & 43.50 & 223.40 \\
\hline 1979 & 103.20 & 10.90 & 57.40 & 5.00 & 0.00 & 0.00 & 0.00 & 0.00 & 0.00 & 3.60 & 5.50 & 88.50 & \\
\hline 1980 & 47.80 & 21.50 & 106.90 & 0.00 & 0.00 & 0.00 & 5.50 & 5.50 & 0.40 & 18.50 & 2.50 & 0.50 & 209.10 \\
\hline 1981 & 1.50 & 13.00 & 29.00 & 16.00 & 1.00 & 0.00 & 0.00 & 4.00 & 1.50 & 0.50 & 2.00 & 80.50 & 329.00 \\
\hline 1982 & 71.90 & 10.50 & 101.50 & 2.00 & 0.20 & 0.00 & 0.00 & 0.00 & 6.00 & 9.50 & 15.50 & 80 & 245.90 \\
\hline 1983 & 5.00 & 31.00 & 6.00 & 0.00 & 0.00 & 1.00 & 0.00 & 5.00 & 5.00 & 0.00 & 2.00 & 18.00 & 73.00 \\
\hline 1984 & 155.00 & 169.40 & 139.30 & 3.00 & 0.00 & 5.30 & 0.00 & 0.00 & 0.00 & 25.40 & 113.40 & 14.50 & 617.30 \\
\hline 1985 & .50 & 150.40 & 90 & & 0.00 & 10.80 & 0.00 & 0.30 & 4.40 & 0.00 & 93.50 & 32.40 & 445.90 \\
\hline 1986 & 119.20 & 50.70 & 137.10 & 5.40 & 0.00 & 0.00 & 0.00 & 19.70 & 0.00 & 0.00 & 0.20 & 97.10 & 429.40 \\
\hline 1987 & 120.10 & 29.30 & 21.10 & 0.80 & 0.10 & 0.00 & 0.30 & 0.00 & 0.50 & 17.50 & 11.50 & 13.10 & 214.30 \\
\hline 1988 & 135.80 & 17.60 & 39.90 & 46.10 & 12.40 & 0.00 & 0.00 & 0.00 & 0.00 & 4.10 & 1.80 & 41.40 & 299.10 \\
\hline 1989 & 108.30 & 73.60 & 27.70 & 40.80 & 0.00 & 0.00 & 0.60 & 0.00 & 0.30 & 0.30 & 4.20 & 6.20 & 262.00 \\
\hline 1990 & 62.70 & 19.60 & 24.70 & 10.80 & 18.60 & 29.40 & 0.00 & 0.40 & 0.20 & 5.00 & 36.60 & 66.90 & 274.90 \\
\hline 1991 & 124.00 & 43.00 & 33.00 & 24.00 & 0.00 & 1.00 & 0.00 & 5.00 & 0.00 & 2.00 & 46.00 & 12.00 & 290.00 \\
\hline 1992 & 92.00 & 9.00 & 16.00 & 2.00 & 0.00 & 0.00 & 0.00 & 3.00 & 0.00 & 6.00 & 47.00 & 42.00 & 217.00 \\
\hline 1993 & 179.00 & 100.00 & 63.00 & 0.00 & 0.00 & 0.00 & 0.00 & 4.00 & 0.00 & 34.00 & 9.00 & 27.00 & 416.00 \\
\hline 1994 & 105.00 & 152.00 & 96.00 & 66.00 & 0.00 & 0.00 & 0.00 & 0.00 & 0.00 & 9.00 & 50.00 & 26.00 & 504.00 \\
\hline 1995 & 79.00 & 11.00 & 26.00 & 1.00 & 9.00 & 0.00 & 0.00 & 0.00 & 1.00 & 0.00 & 1.00 & 41.00 & 169.00 \\
\hline 1996 & 71.00 & 14.00 & 21.00 & 7.00 & 7.00 & 0.00 & 0.00 & 0.00 & 1.00 & 20.00 & 15.00 & 52.00 & 208.00 \\
\hline 1997 & 108.00 & 48.00 & 75.00 & 17.00 & 1.00 & 3.00 & 0.00 & 0.00 & 0.00 & 2.00 & 1.00 & 6.00 & 261.00 \\
\hline Med & 99.69 & 70.51 & 49.30 & 10.64 & 1.94 & 1.56 & 0.23 & 4.04 & 1.67 & 7.60 & 22.90 & 38.27 & 304.36 \\
\hline
\end{tabular}


PERFIL LITOLÓGICO DE POÇOS ZONA DO AYRO -PERU E CHARAÑA - BOLIVIA
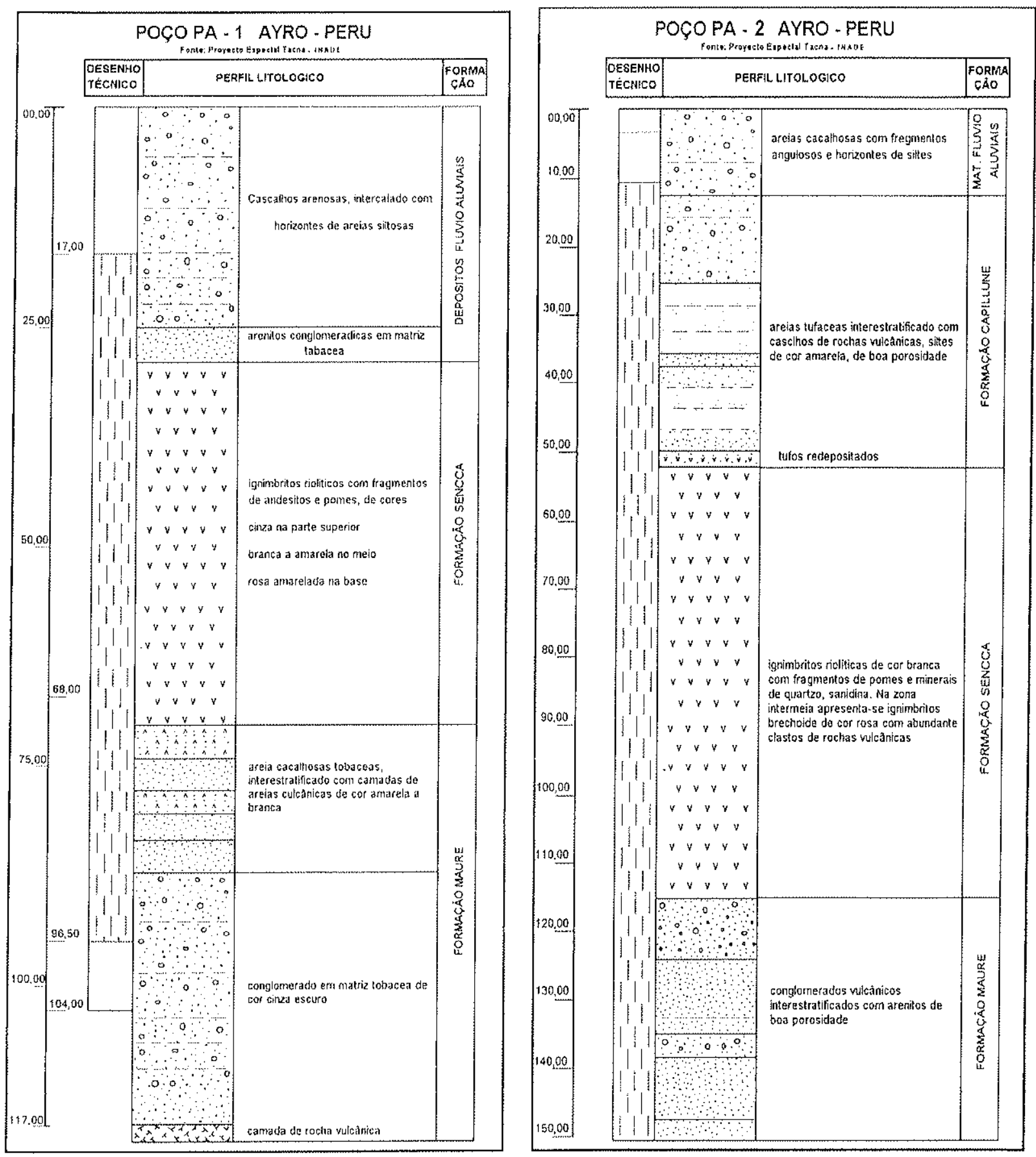
ANEXO II

PERFIL LITOLÓGICO DE POÇOS ZONA DO AYRO -PERU E CHARAÑA - BOLIVIA
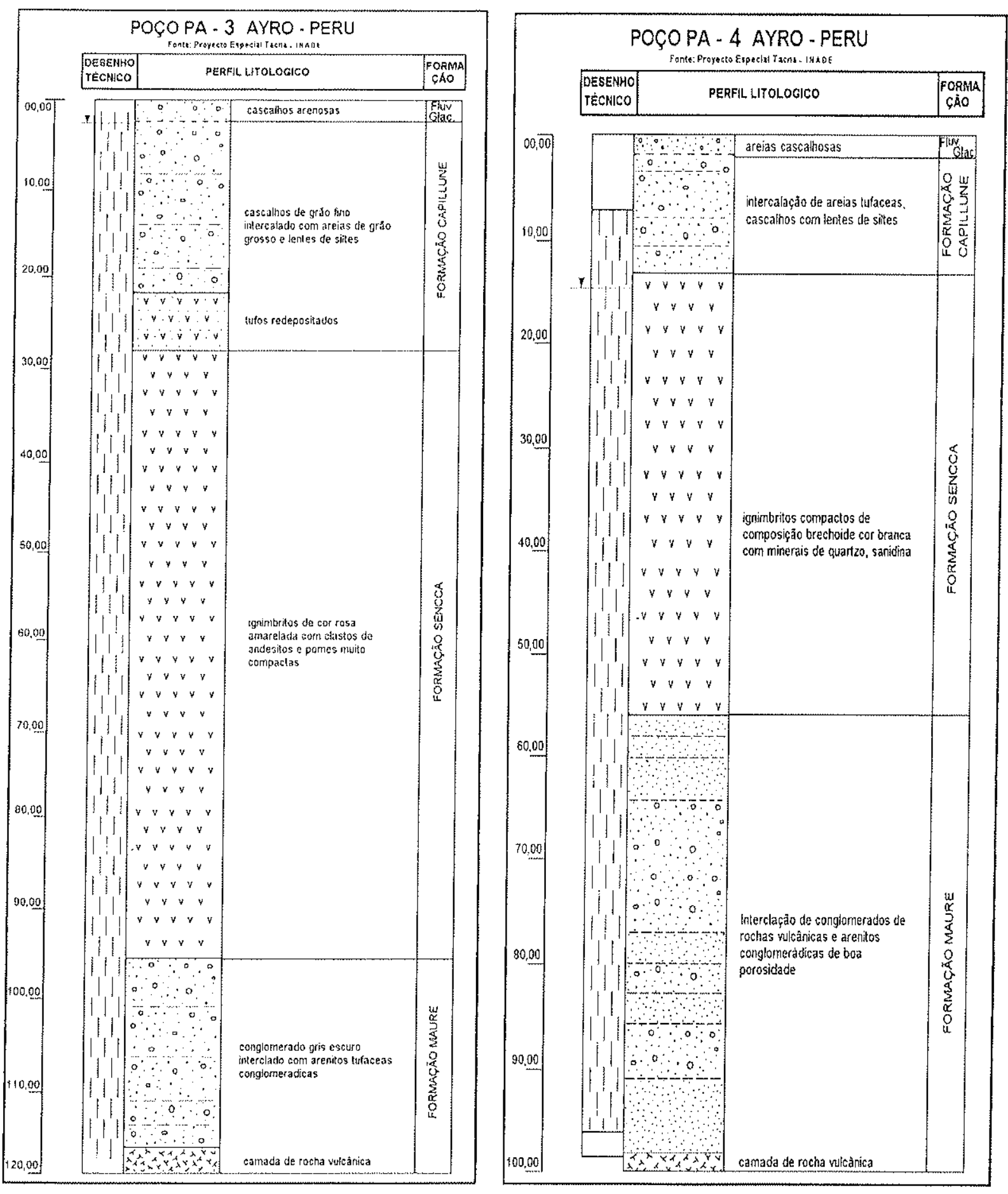
ANEXO II

PERFIL LITOLÓGICO DE POÇOS ZONA DO AYRO -PERU E CHARAÑA - BOLIVIA
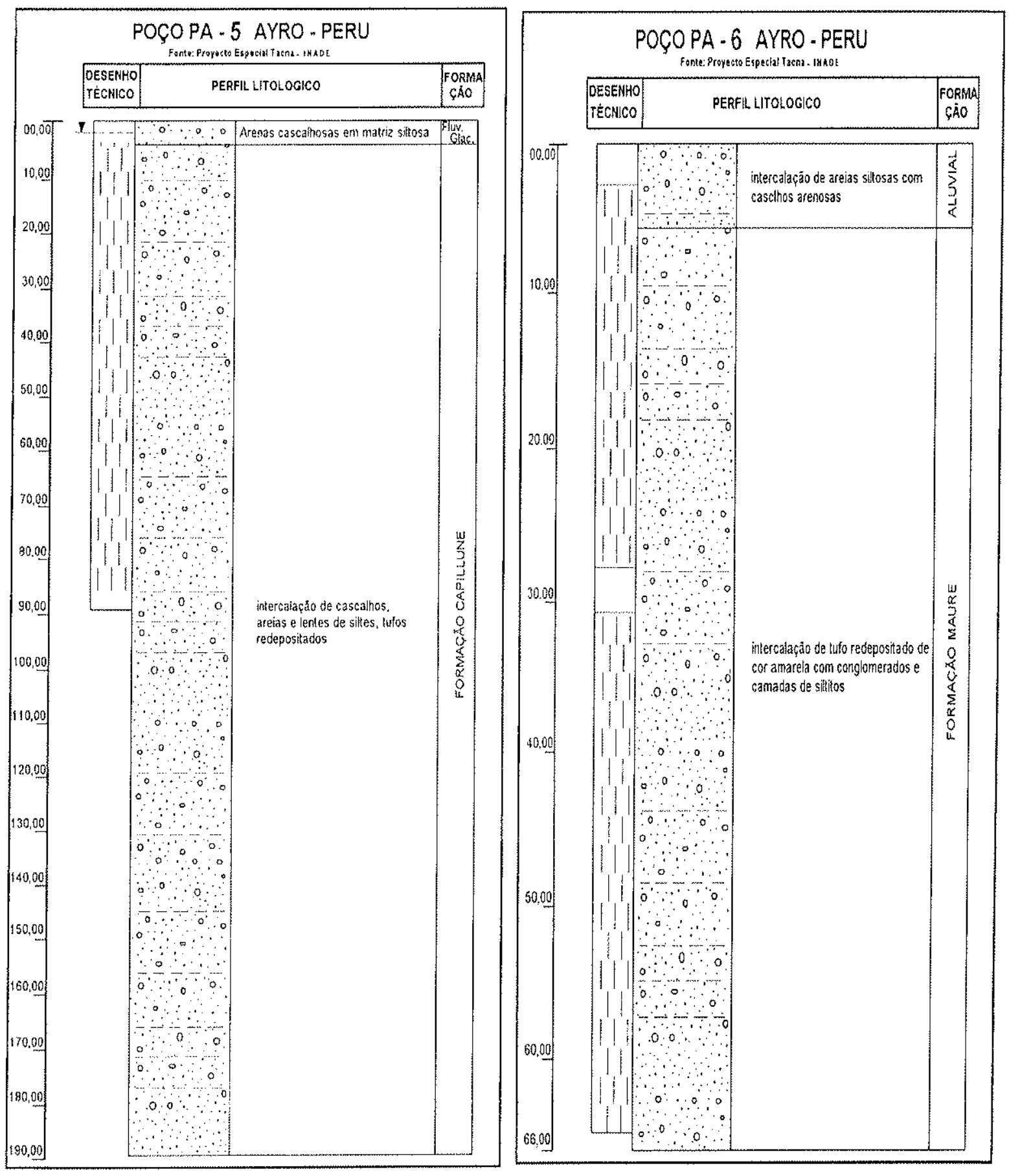
ANEXO ॥

PERFIL LITOLÓGICO DE POÇOS ZONA DO AYRO -PERU E CHARAÑA - BOLIVIA

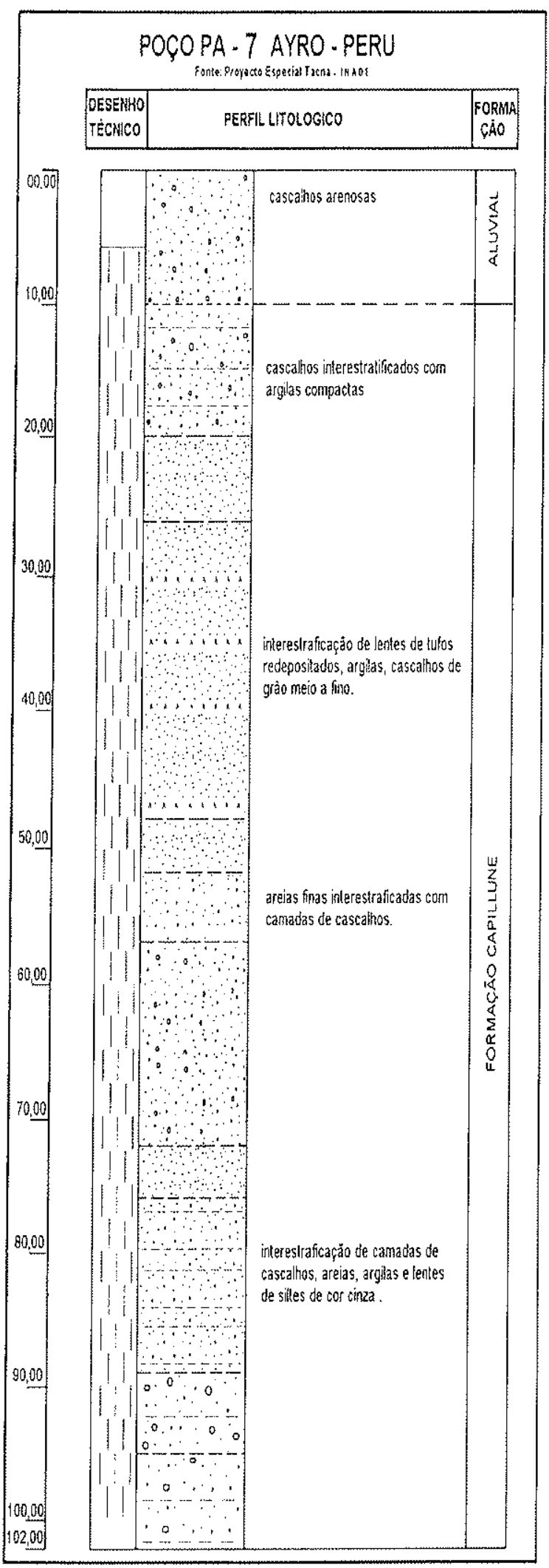

|


ANEXO II

PERFIL LITOLÓGICO DE POÇOS ZONA DO AYRO -PERU E CHARAÑA - BOLIVIA

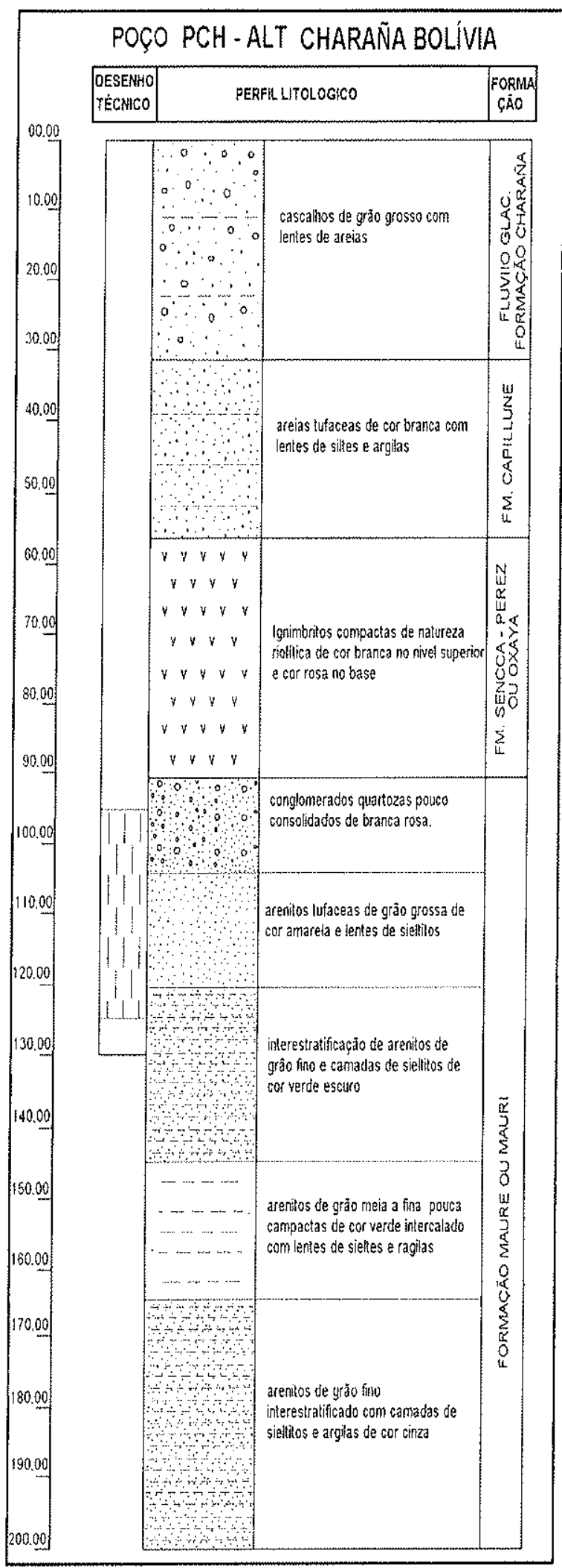


ANEXOII

RESULTADOS DE INTERPRETAÇÃO QUANTITATIVA DE SONDEGENS ELÉTRICAS VERTICAIS

\begin{tabular}{|c|c|c|c|c|c|c|c|c|c|c|c|c|}
\hline \multirow{2}{*}{$\begin{array}{l}\text { Núm. } \\
S E V\end{array}$} & \multicolumn{2}{|c|}{ Camada } & \multicolumn{2}{|c|}{ Camada 1} & \multicolumn{2}{|c|}{ Camada 2} & \multicolumn{2}{|c|}{ Camada 3} & \multicolumn{2}{|c|}{ Camada 4} & \multicolumn{2}{|c|}{ Camada 5} \\
\hline & $h^{\circ}$ & $\rho^{\circ}$ & h1 & $\rho 1$ & $h 2$ & $\rho 2$ & h3 & $\begin{array}{ll}\rho & 3\end{array}$ & $h 4$ & $\rho 4$ & $h 5$ & $\rho 5$ \\
\hline 1 & 5 & 130 & & & 20 & 39 & & & 49 & 68 & & 16 \\
\hline 2 & 6 & 120 & & & 49 & 67 & & & 79 & 78 & & 25 \\
\hline 3 & 5 & 160 & & & 58 & 80 & & & 94 & 112 & & 22 \\
\hline 4 & 7 & 110 & & & 76 & 48 & & & & & & 12 \\
\hline 5 & 3 & 120 & 8.0 & 96 & 22 & 62 & & & 112 & 37 & & 27 \\
\hline 6 & 3 & 300 & 8.0 & 145 & 61 & 63 & & & 104 & 105 & & 24 \\
\hline 7 & 10 & 100 & 21 & 65 & 139 & 38 & & & 120 & 34 & & 15 \\
\hline 8 & 4 & 280 & 23 & 119 & 121 & 56 & & & 97 & 46 & & 42 \\
\hline 9 & 2 & 180 & 28 & 128 & 136 & 63 & & & 75 & 72 & & 14 \\
\hline 10 & 3 & 270 & 12 & 135 & 51 & 70 & & & 170 & 95 & & 19 \\
\hline 11 & 3 & 186 & 27 & 118 & & & & & 166 & 82 & & 13 \\
\hline 12 & 5 & 72 & 56 & 50 & & & & & 164 & 40 & & 11 \\
\hline 13 & 2 & 89 & 7 & 49 & 18 & 79 & & & 220 & 55 & & 11 \\
\hline 14 & 2 & 521 & 15 & 189 & 99 & 64 & & & 226 & 48 & & 18 \\
\hline 15 & 3 & 201 & 9 & 173 & 72 & 76 & & & 191 & 50 & & 18 \\
\hline 16 & 2 & 540 & 8 & 196 & 44 & 82 & & & 238 & 58 & & 23 \\
\hline 17 & 2 & 100 & 5 & 188 & 109 & 79 & & & 212 & 52 & & 15 \\
\hline 18 & 7 & 182 & & & 46 & 86 & & & 168 & 67 & & 17 \\
\hline 19 & 5 & 135 & & & & & & & 138 & 68 & & 16 \\
\hline 20 & 2 & 96 & 21 & 79 & & & & & 186 & 42 & & 22 \\
\hline 21 & 3 & 106 & 5 & 162 & 18 & 72 & & & 173 & 46 & & 16 \\
\hline 22 & 3 & 123 & 12 & 174 & 37 & 76 & & & 149 & 32 & & 14 \\
\hline 23 & 10 & 152 & & & 43 & 83 & & & 168 & 45 & & 8 \\
\hline 24 & 2 & 118 & 15 & 128 & 8 & 42 & 25 & $\$ 29$ & 126 & 54 & & 6 \\
\hline 25 & 3 & 386 & 10 & 184 & 32 & 79 & & & $\$ 18$ & 73 & & 10 \\
\hline 26 & 2 & 101 & 9 & 154 & 79 & 64 & & & 140 & 119 & & 18 \\
\hline 27 & 3 & 83 & 8 & 139 & 92 & 72 & & & 132 & 141 & & 10 \\
\hline 28 & 2 & 102 & 3 & 79 & 22 & 102 & & & 114 & 64 & & 13 \\
\hline 29 & 3 & 96 & 14 & 106 & 88 & 83 & & & 211 & 101 & & 18 \\
\hline 30 & & & & & & & & & & & & \\
\hline 31 & 8 & 98 & 31 & 56 & 88 & 110 & & & & & & 42 \\
\hline 32 & 6 & 105 & 31 & 56 & 32 & 81 & 89 & 131 & & 76 & & \\
\hline 33 & 9 & 140 & 14 & 95 & 44 & 89 & 83 & 124 & & 68 & & \\
\hline 34 & 6 & 146 & 27 & 81 & 36 & 75 & 47 & 129 & & 76 & & \\
\hline 35 & 2 & 110 & 21 & 135 & 54 & 102 & 69 & 132 & & 54 & & \\
\hline 36 & 2 & 148 & 12 & 119 & 68 & 70 & 98 & 110 & & 48 & & \\
\hline 37 & 7 & 140 & 41 & 76 & 69 & 207 & & & & 69 & & \\
\hline 38 & 3 & 180 & 22 & 79 & 96 & 208 & & & & 49 & & \\
\hline 39 & 3 & 132 & 23 & 82 & 79 & 162 & & & & 76 & & \\
\hline 40 & 3 & 76 & 19 & 95 & 73 & 114 & & & 205 & 109 & & 28 \\
\hline 41 & 2 & 87 & 12 & 167 & 68 & 126 & & & 216 & $\$ 36$ & & 19 \\
\hline 42 & 4 & 164 & 10 & 103 & 59 & 144 & & & 235 & 129 & & 15 \\
\hline 43 & 3 & 79 & 10 & 135 & 62 & 157 & & & 112 & 180 & & 25 \\
\hline 44 & 2 & 106 & 18 & 132 & 71 & 182 & & & 131 & 158 & & 24 \\
\hline
\end{tabular}


ANEXO III

RESULTADOS DE INTERPRETAÇÃO QUANTITATIVA DE SONDEGENS ELÉTRICAS VERTICAIS

\begin{tabular}{|c|c|c|c|c|c|c|c|c|c|c|c|c|}
\hline \multirow{2}{*}{$\begin{array}{l}\text { Núm. } \\
\text { SEV }\end{array}$} & \multicolumn{2}{|c|}{ Camada } & \multicolumn{2}{|c|}{ Camada 1} & \multicolumn{2}{|c|}{ Camada 2} & \multicolumn{2}{|c|}{ Camada 3} & \multicolumn{2}{|c|}{ Camada 4} & \multicolumn{2}{|c|}{ Camada 5} \\
\hline & $h .^{\circ}$ & $\rho^{\circ}$ & $h 1$ & $\rho 1$ & $h 2$ & $\rho 2$ & $h 3$ & $\rho 3$ & $h 4$ & $\rho 4$ & h5 & $\rho 5$ \\
\hline 45 & 4 & 56 & 9 & 31 & 36 & 186 & & & & 163 & & \\
\hline 46 & 4 & 260 & 13 & 83 & 42 & 143 & & & & 47 & & \\
\hline 47 & 4 & 104 & 16 & 92 & 58 & 139 & & & & 62 & & \\
\hline 48 & 2 & 171 & 9 & 135 & 54 & 153 & & & 92 & 103 & & 35 \\
\hline 49 & 3 & 183 & 31 & 106 & 59 & 125 & & & 89 & 164 & & 38 \\
\hline 50 & 5 & 162 & 14 & 94 & 39 & 132 & & & & 42 & & \\
\hline 51 & 2 & 176 & 14 & 85 & 54 & 141 & & & & 69 & & \\
\hline 52 & 2 & 182 & 18 & 81 & 66 & 162 & & & & 79 & & \\
\hline 53 & 2 & 154 & 22 & 129 & 51 & 157 & & & & 102 & & \\
\hline 54 & 4 & 114 & 28 & 82 & 54 & 162 & & & & 78 & & \\
\hline 55 & 2 & $\$ 52$ & 19 & 86 & 68 & 176 & & & & 104 & & \\
\hline 56 & 2 & 122 & 24 & 81 & 40 & 161 & & & & 51 & & \\
\hline 57 & 5 & 140 & 32 & $76^{\circ}$ & 63 & 182 & & & & 69 & & \\
\hline 58 & 3 & 98 & 19 & $\$ 10$ & 140 & 113 & & & & 30 & & \\
\hline 59 & 4 & 111 & 15 & 121 & 138 & 119 & & & & 42 & & \\
\hline 60 & 3 & 120 & 154 & 108 & & & & & & 32 & & \\
\hline 61 & 2 & 85 & 15 & 116 & 193 & 184 & & & & 52 & & \\
\hline 62 & 5 & 119 & 32 & 146 & 179 & 165 & & & & 50 & & \\
\hline 63 & 6 & 266 & 23 & 183 & 31 & 173 & & & & 32 & & \\
\hline 64 & 7 & 231 & 11 & 114 & 42 & 178 & & & & 23 & & \\
\hline 65 & 5 & 329 & 29 & 198 & 32 & 159 & & & & 29 & & \\
\hline 66 & 6 & 317 & 36 & 249 & 47 & 152 & & & & 49 & & \\
\hline 67 & 4 & 151 & 12 & 297 & 53 & 140 & & & & 42 & & \\
\hline 68 & 3 & 178 & 21 & 241 & 44 & 132 & & & & 43 & & \\
\hline 69 & 5 & 329 & 38 & 413 & 125 & 61 & & & & 12 & & \\
\hline 70 & 5 & 150 & 48 & 284 & & & & & & 63 & & \\
\hline 71 & 10 & 139 & 12 & 420 & 65 & 250 & & & & 76 & & \\
\hline 72. & 19 & 126 & 43 & 90 & 49 & 349 & 237 & 58 & & & & 6 \\
\hline 73 & 6 & 125 & 43 & 76 & 61 & 142 & 158 & 118 & & & & 12 \\
\hline 74 & 9 & 124 & 84 & 79 & 39 & 192 & & & & & & 21 \\
\hline 75 & 8 & 230 & 72 & 50 & 41 & 179 & 89 & 68 & & & & 14 \\
\hline 76 & 7 & 85 & 34 & 50 & 37 & 109 & 86 & 95 & & & & 30 \\
\hline 77 & 7 & 200 & 46 & 40 & 49 & 176 & 106 & 83 & & & & 37 \\
\hline 78 & 6 & 89 & 132 & 35 & $\$ 20$ & 51 & & & & & & 6 \\
\hline 79 & 15 & 210 & 72 & 42 & 54 & 119 & 172 & 68 & & & & 5 \\
\hline 80 & 3 & 10 & 25 & 30 & 210 & 42 & & & & & & 27 \\
\hline 81 & 20 & 83 & 24 & 33 & & & & & & & & 27 \\
\hline 82 & 14 & 160 & 137 & 79 & 42 & 164 & 87 & 68 & & & & 30 \\
\hline 83 & 12 & 82 & 86 & 81 & 47 & 213 & 91 & 74 & & & & 22 \\
\hline 84 & 6 & 260 & 60 & 69 & 48 & 149 & 89 & 83 & & & & 11 \\
\hline 85 & 2 & 95 & 29 & 86 & 32 & 135 & 101 & 86 & & & & 21 \\
\hline 86 & 5 & 480 & 49 & 121 & 62 & 216 & 139 & 68 & & & & 9 \\
\hline 87 & 2 & 270 & 36 & 79 & 54 & 146 & 123 & 67 & & & & 27 \\
\hline 88 & 8 & 200 & 58 & 34 & 59 & 164 & 98 & 82 & & & & 15 \\
\hline 89 & 5 & $\uparrow 80$ & 43 & 30 & 59 & 196 & 118 & 79 & & & & 30 \\
\hline 90 & 9 & 196 & 73 & 45 & 51 & 249 & 82 & 63 & & & & 12 \\
\hline
\end{tabular}


ANEXO II

RESULTADOS DE INTERPRETAÇÃO QUANTITATIVA DE SONDEGENS ELÉTRICAS VERTICAIS

\begin{tabular}{|c|c|c|c|c|c|c|c|c|c|c|c|c|}
\hline \multirow{2}{*}{$\frac{\text { Num. }}{\text { S EV }}$} & \multicolumn{2}{|c|}{ Camada } & \multicolumn{2}{|c|}{ Camada 1} & \multicolumn{2}{|c|}{ Camada 2} & \multicolumn{2}{|c|}{ Camada 3} & \multicolumn{2}{|c|}{ Camada 4} & \multicolumn{2}{|c|}{ Camada 5} \\
\hline & h. & $\rho^{\circ}$ & $h 1$ & $\rho 1$ & $h 2$ & $\rho 2$ & h 3 & $\rho 3$ & $h 4$ & $\rho 4$ & $h 5$ & $\rho 5$ \\
\hline 91 & 10 & 180 & 82 & 54 & 43 & 240 & 73 & 67 & & & & 19 \\
\hline 92 & 5 & 145 & 50 & 61 & 52. & 164 & 93 & 84 & & & & 31 \\
\hline 93 & 7 & 200 & 126 & 114 & 40 & 138 & 76 & 53 & & & & 35 \\
\hline 94 & 6 & 118 & 114 & 132 & 52 & 141 & 90 & 71 & & & & 5 \\
\hline 95 & 16 & 218 & 39 & 216 & & & & 69 & & & & \\
\hline 96 & 20 & 155 & 51 & 173 & 68 & 354 & & 76 & & & & \\
\hline 97 & 18 & 180 & 93 & 141 & 57 & 148 & & 51 & & & & \\
\hline 98 & 24 & 186 & 75 & 234 & & & & 97 & & & & \\
\hline
\end{tabular}

SE104V : Sondagem Elétrico Vertical

$h:$ Espessura(m)

$\rho:$ Resistividade ohm.m 


\title{
ANEXO IV
}

\section{DADOS DE VAZÃO DE DESCARGA MÉDIA MENSAL DO RIO UCHUSUMA}

\author{
ESTAÇÃO LIMNIMÉTRICA BOCATOMA UCHUSUMA-PERU \\ Periodo 1963 - 1997 Fonte PET. SENAMHI \\ Bacia Mauri, Dpto Tacna, Prov. Tacna, Dist. Palca
}

\begin{tabular}{|c|c|c|c|c|c|c|c|c|c|c|c|c|c|}
\hline Ano & Jan & Fev & Mar & $\mathrm{Abr}$ & $\mathrm{Mai}$ & Jun & Jul & Ago & Set & Out & Nov & Dez & Total \\
\hline 1963 & 0,563 & 1,275 & 1,674 & 0,581 & 0,587 & 0,907 & 0,914 & 0,792 & 0,824 & 0,678 & 0,775 & 0,836 & 0866 \\
\hline 1964 & 0,806 & 1,088 & 0.923 & 0,824 & 0.710 & 0,597 & 0,734 & 0,640 & 0,485 & 0,554 & 0,698 & 0,616 & 0,721 \\
\hline 1965 & 0,653 & 0,885 & 0,837 & 0,707 & 0,673 & 0,548 & 0,632 & 0,605 & 0,511 & 0,470 & 0,603 & 0,627 & 0,646 \\
\hline 1966 & 0,553 & 0,577 & 0,601 & 0,551 & 0,392 & 0,497 & 0,490 & 0,531 & 0,639 & 0,504 & 0,571 & 0,590 & 0,541 \\
\hline 1967 & 0,552 & 0,702 & 1,207 & 0,519 & 0,334 & 0,550 & 0,638 & 0,558 & 0,509 & 0,414 & 0,483 & 0,579 & 0,587 \\
\hline 1968 & 0,747 & 1,220 & 0,841 & 0,841 & 0,466 & 0,639 & 0,615 & 0,588 & 0,425 & 0,453 & 0,714 & 0,711 & 0,688 \\
\hline 1969 & 0,676 & 1,111 & 1,014 & 0.546 & 0,562 & 0,536 & 0,588 & 0,607 & 0,574 & 0,567 & 0,691 & 0,651 & 0,677 \\
\hline 1970 & 0,817 & 0,990 & 0,848 & 0,709 & 0,614 & 0,578 & 0,620 & 0,561 & 0,533 & 0,537 & 0,530 & 0.531 & 0,656 \\
\hline 1971 & 0,590 & 1,153 & 0,867 & 0.673 & 0,605 & 0,552 & 0,590 & 0,660 & 0,558 & 0,534 & 0,619 & 0,616 & 0,668 \\
\hline 1972 & 1,086 & 1,147 & 1.552 & 1,875 & 0,933 & 0,787 & 0,769 & 0,762 & 0,705 & 0,577 & 0,600 & 0,781 & 0,965 \\
\hline 1973 & 1,012 & 1.049 & 1,668 & 1,328 & 1,084 & 0,504 & 0,528 & 0,612 & 0,488 & 0,406 & 0,615 & 0,641 & 0,828 \\
\hline 1974 & 0,970 & 1,699 & 1,305 & 1,069 & 0,495 & 0,519 & 0.554 & 0,813 & 0,782 & 0,584 & 0,689 & 0,673 & 0,846 \\
\hline 1975 & 0,806 & 1.724 & 1,847 & 0,846 & 0,774 & 0.739 & 0,751 & 0,733 & 0,659 & 0,547 & 0,593 & 0,767 & 0,899 \\
\hline 1976 & 1,447 & 1,746 & 1,443 & 0,962 & 0,850 & 0,831 & 0,812 & 0,751 & 0,556 & 0,503 & 0,459 & 0,470 & 0,903 \\
\hline 1977 & 0,643 & 0,891 & 2,096 & 0,876 & 0,385 & 0.196 & 0,206 & 0,232 & 0.484 & 0,519 & 0,682 & 0,745 & 0,663 \\
\hline 1978 & 0,892 & 0,818 & 0,483 & 0,618 & & & 0,456 & 0,587 & 0,529 & 0,477 & 0,445 & 0,357 & 0,550 \\
\hline 1979 & 0,702 & 0,552 & 1,063 & 0,547 & 0,525 & 0.518 & 0,549 & 0.606 & 0,611 & 0,605 & & & 0,658 \\
\hline 1980 & 684 & 0,492 & 2,361 & 0,540 & 0,541 & 0,538 & 0.429 & 0,622 & 0,665 & 0,552 & 0.485 & 0,550 & 0,705 \\
\hline 1981 & 646 & 0,609 & 0,797 & 749 & & & 0,650 & 0,589 & 0,496 & 0,552 & 0,489 & 0,739 & 0,622 \\
\hline 1982 & 0,891 & 1,381 & 1,010 & 0,614 & 0,718 & 0,772 & 0,774 & 0,794 & 0,638 & 0,722 & & & 0,805 \\
\hline 1983 & 614 & 0,723 & 0,636 & 0.649 & 0,601 & 0,620 & 0,594 & 0,579 & 0,503 & 0,561 & 0,507 & 0,588 & 0,596 \\
\hline 1984 & 768 & 0,801 & 1,413 & 1,006 & 0,437 & 0,486 & 0,371 & 0,397 & 0,458 & 0,439 & 0,780 & 0,805 & 0,680 \\
\hline 1985 & 1,147 & 1,334 & 1,651 & 0,836 & & & 0,738 & 0,859 & 0,715 & 1,3 & 0,589 & 0,809 & 0,937 \\
\hline 1986 & 1,007 & 1,140 & 1,249 & 0,558 & 0,569 & 0,806 & 0,801 & 0,805 & 0,667 & 0,9 & 0,791 & 0,9 & 0,860 \\
\hline 1987 & 0,910 & 1,118 & 1,208 & 0,923 & 1,009 & 0,743 & 1.015 & 0,804 & 0,687 & 0,753 & 0,605 & 0,492 & 0,856 \\
\hline 1988 & 1,071 & 1,161 & 824 & 0,758 & 0,621 & 0,443 & 0,456 & 1,133 & 3,697 & 2,191 & 0,736 & 0.831 & 1,160 \\
\hline 1989 & 0,987 & 0,808 & 0,672 & 0,961 & 0,781 & 0,819 & 0,715 & 0,694 & 0,568 & 0,914 & 0,771 & 1,019 & 0,809 \\
\hline 1990 & 1,510 & 0,589 & 1,378 & 0,573 & 0,603 & 0.796 & 0,686 & 0,544 & 0,538 & 0,515 & 0,701 & 0,821 & 0,772 \\
\hline 1991 & 815 & 0,639 & 1,167 & 0,523 & 0,715 & 0,641 & 0.813 & 0,771 & 0.558 & 0,728 & 0,602 & 0,840 & 0,734 \\
\hline 1992 & 1.117 & 0,875 & 0,920 & 0,738 & 1,010 & 0,769 & 0,869 & 0,901 & 0,683 & 0,600 & 0,477 & 0,649 & 0,805 \\
\hline 1993 & 1,322 & 0,850 & 1,225 & 0,545 & 0,906 & 0,783 & 0,939 & 0,857 & 0,728 & 0,864 & 0,711 & 0,909 & 0,887 \\
\hline 1994 & 967 & 0,381 & 0,712 & 0,791 & 0,624 & 0,793 & 0,734 & 0,644 & 0,491 & 0,520 & 0,669 & 0,762 & 0,757 \\
\hline 1995 & 806 & 1,125 & 1,116 & 0.930 & 0,518 & 0,431 & 0,207 & 0,471 & 0,486 & 0,554 & 0,579 & 0,463 & 0,641 \\
\hline 1996 & 0,556 & 0,858 & 0.995 & 0,610 & 0,372 & 0,726 & 0,812 & 0,493 & 0,436 & 0,466 & 0,710 & 0,824 & 0,655 \\
\hline 1997 & 0,637 & 0,996 & 0,724 & 0,637 & 0,767 & 0.554 & 0.859 & 0,558 & 0,530 & 0,550 & 0,632 & 0,739 & 0,682 \\
\hline 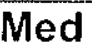 & 0,865 & 1,026 & 1.177 & 0.800 & 0.640 & 0.629 & 0.653 & 0.652 & 0.656 & & 0.622 & 0.703 & 0.750 \\
\hline
\end{tabular}

